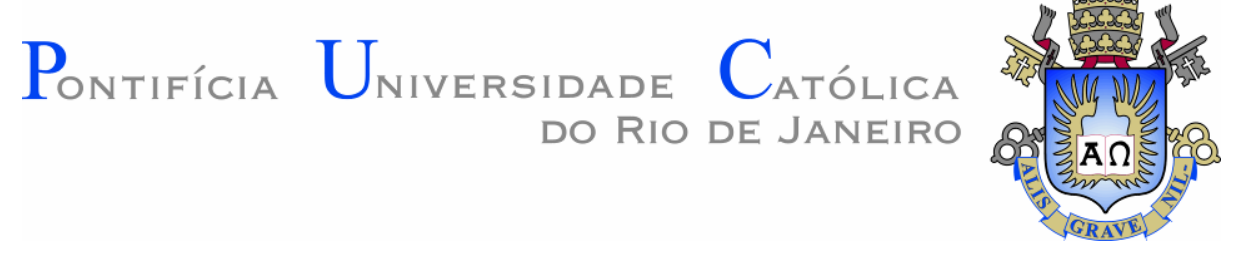

Walter Gabriel Bareiro

\title{
Estudo Experimental e Numérico do Comportamento de Compósitos Refratários em Diferentes Temperaturas
}

Tese apresentada ao Programa de Pós-Graduação em Engenharia Civil da PUC-Rio como requisito parcial para obtenção do grau de Doutor em Engenharia Civil.

Orientadora: Profa ${ }^{a}$. Elisa Dominguez Sotelino

Coorientador: Prof. Flávio de Andrade Silva

Rio de Janeiro

Fevereiro de 2019 
Todos os direitos reservados. É proibida a reprodução total ou parcial do trabalho sem autorização da universidade, do autor e do orientador.

\section{Walter Gabriel Bareiro}

Graduado em Engenharia Civil pela Universidade Nacional de Misiones, UNaM Argentina em 2011. Possui o grau de mestre em Engenharia Civil (Estruturas) pela Pontifícia Universidade Católica do Rio de Janeiro, PUC-Rio em 2015. Foi premiado como Doutorado Nota 10 pelo Estado do Rio de Janeiro através da FAPERJ. Principais áreas de interesse: Materiais compósitos, modelagem numérica e mecânica computacional.

Ficha Catalográfica

\section{Bareiro, Walter Gabriel}

Estudo Experimental e Numérico do Comportamento de Compósitos Refratários em Diferentes Temperaturas/ Walter Gabriel Bareiro; Orientador: Elisa Dominguez Sotelino; Coorientador Flávio de Andrade Silva. - Rio de Janeiro: PUC - Rio, Departamento de Engenharia Civil, 2019.

$161 \mathrm{f}$. il; $29,7 \mathrm{~cm}$.

Tese de Doutorado - Pontifícia Universidade Católica do Rio de Janeiro, Departamento de Engenharia Civil e Ambiental.

Inclui referências bibliográficas.

1. Materiais cimentícios avançados. 2. Metodologia experimental 3. Método de elementos finitos. I. Elisa Dominguez Sotelino. II Flávio de Andrade Silva. III. Pontifícia Universidade Católica do Rio de Janeiro. Departamento de Engenharia Civil. III. Título. 


\section{Agradecimentos}

Primeiramente agradecer a Deus por me acompanhar sempre nos caminhos da vida.

À PUC-Rio pela oportunidade de estudar, pelo suporte acadêmico e ótimo ambiente de estudos.

À CNPq e a FAPERJ pelo apoio financeiro através da concessão da bolsa de estudos e suporte de projeto que possibilitaram a realização desta pesquisa.

À Prof. Elisa e ao Prof. Flávio pela disponibilidade, conhecimento compartilhados e orientações que foram de grande ajuda ao longo desta pesquisa. A todos os professores do Departamento de Engenharia Civil da PUC-Rio pela contribuição na minha formação.

Aos funcionários do Departamento, pela competência é predisposição de atender e ajudar com os procedimentos da PUC-Rio.

A minha família pelo incentivo em todo momento para alcançar meus objetivos.

Aos amigos de sempre, colegas e novos amigos que fiz nesse tempo no dia a dia.

Ao Rio de Janeiro, e ao Brasil pelas experiências vividas e as novas experiências que virão, minha gratidão de sempre.

Obrigados a todos que fizeram parte disto. Abraço! 


\section{Resumo}

Bareiro, Walter Gabriel; Dominguez Sotelino, Elisa (orientadora); de Andrade Silva, Flávio (Coorientador). Estudo Experimental e Numérico do Comportamento de Compósitos Refratários em Diferentes Temperaturas. Rio de Janeiro, 2019. 161p. Tese de Doutorado Departamento de Engenharia Civil e Ambiental, Pontifícia Universidade Católica do Rio de Janeiro.

Neste estudo diferentes concretos a base de cimento aluminoso foram desenvolvidos e caracterizados em termos de seu comportamento termomecânico para uma ampla faixa de temperaturas $\left(25-1200^{\circ} \mathrm{C}\right)$. Primeiramente, três refratários com diferentes teores de alumina (51, 71 e 90\% em peso) foram estudados para caracterizar seus comportamentos químico e mecânico em diferentes temperaturas. Para isso vários tipos de ensaios experimentais, após aquecimento e resfriamento, foram realizados: ensaios microestruturais, químicos, de compressão uniaxial, tração direta e flexão em três pontos. Com esses resultados foi desenvolvido, através de simulações numéricas, um novo tipo de revestimento combinando os três refratários em camadas. A solução mais eficiente em termos de gradiente térmico foi a combinação que usou o refratário com $90 \%$ de alumina como camada interna e os refratários de $71 \%$ e $51 \%$ como as camadas média e externa, respectivamente. Um material compósito refratário reforçado com fibras de aço inoxidável foi também desenvolvido. Para isso o concreto refratário com $51 \%$ de alumina foi selecionado, pois apresentou o melhor comportamento mecânico nas temperaturas analisadas (até $1200^{\circ} \mathrm{C}$ ). Três tipos de fibras foram consideradas: lisa, ondulada e recartilhada. Além da realização dos mesmos tipos de ensaios feitos para a matriz refratária, foram também realizados ensaios cíclicos, de arrancamento de fibras e estruturais (painéis circulares). Os ensaios forneceram os parâmetros necessários para o modelo constitutivo de dano plástico disponível no programa de elementos finitos ABAQUS. O modelo constitutivo foi validado através de simulações termomecânicas do ensaio do painel circular. Concluiu-se que o comportamento termomecânico dos compósitos refratários com a adição 
de fibras de aço inoxidável foi significativamente melhor do que do refratário sem reforço. O compósito com a fibra recartilhada foi o que teve o melhor desempenho devido à forte aderência da fibra com a matriz. Os resultados experimentais e as simulações numéricas mostraram que o efeito de reforço beneficia o comportamento mecânico pré-pico e pós-pico dos compósitos refratários. A influência do endurecimento por deformação observada na fase inicial das curvas e do abrandamento (softening) pós-pico indicam a importância desses parâmetros para projetos estruturais. $\mathrm{O}$ dano do compósito refratário foi analisado através da análise de correlação digital de imagem para estudar a propagação da fissura nas várias temperaturas. Observou-se que com o aumento de temperatura a propagação da fissura fica mais lenta e a abertura da fissura fica menos acentuada. Conclui-se então que esses materiais são apropriados para utilização em aplicações que envolvem temperaturas elevadas.

\section{Palavras - chave}

Compósitos refratários; alumina; comportamento termomecânico. 


\section{Abstract}

Bareiro, Walter Gabriel; Dominguez Sotelino, Elisa (Advisor); de Andrade Silva, Flávio (Co-advisor). Experimental and Numerical Study of Refractory Composites Behavior at Different Temperatures. Rio de Janeiro, 2019. 161p. Tese de Doutorado - Departamento de Engenharia Civil e Ambiental, Pontifícia Universidade Católica do Rio de Janeiro.

In this study different concretes based on aluminous cement were developed and characterized in terms of their thermomechanical behavior over a wide temperature range $\left(25-1200^{\circ} \mathrm{C}\right)$. First, three refractories with different alumina contents $(51,71$ and $90 \mathrm{wt} \%)$ were studied to characterize their chemical and mechanical behavior at different temperatures. For this, several types of experimental tests, after heating and cooling, were carried out: microstructural, chemical, uniaxial compression tests, direct tensile tests and three-point bending test. With these results, a new type of coating was developed through numerical simulations combining the three refractories in layers. The most efficient solution in terms of thermal gradient was the combination that used the refractory with $90 \%$ of alumina as the inner layer and the refractories of $71 \%$ and $51 \%$ as the middle and outer layers, respectively. A refractory composite material reinforced with stainless steel fibers was developed. For this, the refractory concrete with $51 \%$ of alumina was selected, since it presented the best mechanical behavior at the analyzed temperatures (up to $1200^{\circ} \mathrm{C}$ ). Three types of fibers were considered: straight, wavy and knurled. In addition to performing the same types of tests for the refractory matrix, cyclic, fiber pullout and structural tests (round panels) were also performed. The tests provided the parameters for the Damage Plasticity constitutive model available in the finite element software ABAQUS. The constitutive model was validated through thermomechanical simulations of the round panel test. It was concluded that the thermo-mechanical behavior of the refractory composites with the addition of stainless steel fibers was significantly better than the non-reinforced refractory. 
The composite with the knurled fiber was the one that had the best performance due to the strong bond of the fiber to the matrix. The experimental results and numerical simulations showed that the reinforcement effect benefits the pre-peak and post-peak mechanical behavior of the refractory composites. The influence of the strain-hardening observed in the initial phase of the curves and the softening post-peak indicated the importance of these parameters for structural projects. The damage of the refractory composite was analyzed through digital image correlation to study the crack propagation at various temperatures. It has been observed that with the increase in temperature the propagation of the crack becomes slower and the opening of the crack becomes less pronounced. It is therefore concluded that such materials are suitable for use in applications involving high temperatures.

\section{Keywords}

Refractory composites; alumina; thermos-mechanical behavior. 


\section{Sumário}

1 Introdução 13

1.1. Motivação 14

1.2. Objetivos 15

1.3. Estrutura do trabalho 15

2 Revisão Bibliográfica 17

2.1. Comportamento de concretos refratários com a temperatura 17

$\begin{array}{ll}\text { 2.1.1. Comportamento mecânico } & 17\end{array}$

2.1.2. Comportamento químico 24

2.2. Concretos refratários reforçados com fibras metálicas 28

2.3. Modelagem do comportamento termomecânico de concretos 29

2.3.1. Tensões térmicas 29

2.3.2. Modelagem do dano do concreto 33

2.3.3. Fundamentos do Concrete Damage Platicity 36

3 Metodologia e resultados 39

3.1. Comportamento químico e mecânico dos concretos refratários de alumina em diferentes temperaturas (Artigo A). 40

3.2. Simulação do comportamento termomecânico de concretos refratários aplicados em revestimentos (Artigo B).

3.3. Comportamento termomecânico dos compósitos refratários reforçados com fibras de aço inoxidável (Artigo $\mathrm{C}$ ).

4 Conclusões e sugestões para trabalhos futuros

5 Referências Bibliográficas

Anexos

Artigo A The influence of alumina content on the chemical and mechanical behavior of refractory concretes fired at different temperatures 
Artigo B Numerical modeling of the thermo-mechanical behavior of refractory concrete lining

Artigo C Thermo-mechanical behavior of stainless steel fiber reinforced refractory concrete: experimental and numerical analysis 119 


\section{Lista de Figuras}

Figura 2.1 - Desenvolvimento de danos em um ensaio a flexão com entalhe

SIMONIN et al., 2002)

Figura 2.2 - Resposta mecânica de um refratário típico de alumia

e silicato em função da temperatura (AKSEL et al., 2003)

Figura 2.3 - Testes de compressão em concreto refratário aluminoso após

a queima em diferentes temperaturas. (DÍAZ et al., 2008)

Figura 2.4 - Curvas tensão-deformação à compressão uniaxial de

concretos refratários com andalusita e bauxita a diferentes temperaturas.

(OUEDRAOGO et al., 2011)

Figura 2.5 - Comportamento à tração em diferentes temperaturas dos

concretos refratários (a) agregado andalusite (b) agregado bauxita.

Figura 2.6 - Temperatura ambiente e resistência à tração a alta

temperatura do concreto And-LCC após tratamentos térmicos.

(MARZAGUI, 2005)

Figura 2.7 - Variação do Módulo de ruptura de concretos refratários com

alto teor de alumina queimados em diferentes temperaturas para ensaios a quente e residual (WYGANT e BUKLEY, 1954 apud BAZANT et. al 1996)

Figura 2.8 - Identificação do dano em ambos os tipos de concreto após tratamentos térmicos (a) concreto à prova de fogo Andalusita a $700^{\circ} \mathrm{C}(\mathrm{b})$ concreto à prova de fogo Bauxita a $700^{\circ} \mathrm{C}$ (c) concreto à prova de fogo Andalusita a $900^{\circ} \mathrm{C}$ (d) concreto à prova de fogo Bauxita a $700^{\circ} \mathrm{C}$ (KAKROUDI et al., 2008)

Figura 2.9 - Transformações durante a queima de concretos refratários de alumina contendo CAC

Figura 2.10 - Evolução do módulo de elasticidade de um concreto refratário aluminoso coma temperatura (NONNET; LEQUEUX; BOCH, 1999)

Figura 2.11 - Representação das tensões térmicas um concreto com vários gradientes de temperaturas

Figura 2.12 - Tensão e temperatura em função do espessura da camada no instante de tempo 0:40 e 1:40

Figura 2.13 - Representação esquemática da distribuição de tensão ao longo da fissura em um material típico quase fragil. (BAZANT, et .al., 1998). Figura 2.14 - (a) Domínio de computação e condições de contorno usadas para a análise de danos e (b) Contorno de dano após 10s de aquecimento. 
Figura 2.15 - Comportamento do concreto sob a) compressão uniaxial b) tração (ABAQUS USER MANUAL, 2008).

Figura 2.16 - Superfície de produção biaxial no modelo CDP (ABAQUS USER MANUAL, 2008).

Figura 3.1 - Corpos de provas dos diferentes concretos refratários a base de cimento aluminoso. 


\section{Lista de símbolos}

\begin{tabular}{|c|c|c|}
\hline & $k$ & Condutividade térmica \\
\hline & $\rho$ & Densidade \\
\hline & $C_{p}$ & Calor específico \\
\hline & $E$ & Módulo de Elasticidade \\
\hline & $v$ & Coeficiente de Poisson \\
\hline & $E_{0}$ & Módulo de Elasticidade não danificado \\
\hline & $f_{\mathrm{c}}$ & Resistência à compressão \\
\hline & $\varepsilon_{0 t}^{e l}$ & Deformação elástica do material não danificado em tração \\
\hline & $\varepsilon_{t}^{e l}$ & Deformação elástica do material com danificado em tração \\
\hline & $\varepsilon_{0 c}^{e l}$ & Deformação elástica do material com danificado em tração \\
\hline & $\varepsilon_{c}^{e l}$ & Deformação elástica do material com danificado em tração \\
\hline & $\varepsilon_{t}^{c k}$ & Deformação de fissuração do material não danificado \\
\hline & $\varepsilon_{t}^{p l}$ & Deformação plástica do material danificado em tração \\
\hline & $\varepsilon_{c}^{i n}$ & Deformação inelástica do material não danificado \\
\hline & $\varepsilon_{c}^{p l}$ & Deformação plástica do material danificado à compressão \\
\hline & $d_{t}$ & Parâmetro de dano em tração \\
\hline & $d_{c}$ & Parâmetro de dano em compressão \\
\hline & $\mathrm{G}_{\mathrm{f}}$ & Energia de fratura \\
\hline
\end{tabular}




\section{1 \\ Introdução}

Os compósitos refratários são amplamente utilizados na indústria siderúrgica, química, de cimento e vidro. Esses materiais resistem a altas temperaturas, tensões mecânicas, tensões térmicas, ataques químicos e abrasivos do ambiente a que são expostos. As matérias primas mais utilizadas na produção de materiais refratários aplicados na indústria são alumina $\left(\mathrm{Al}_{2} \mathrm{O}_{3}\right)$, sílica $\left(\mathrm{SiO}_{2}\right)$ e magnésia $(\mathrm{MgO}) . \mathrm{O}$ aumento continuo da produtividade nas indústrias está diretamente relacionado à vida útil dos materiais refratários usados e na redução do consumo de energia. A demanda global de materiais refratários é significativa, em 2012 foi em torno de 45 milhões de toneladas (WORLD STEEL ASSOCIATION, 2015). Isso enfatiza a importância no desenvolvimento de materiais refratários mais eficientes. Os concretos refratários formam parte desses materiais e são compostos de uma mistura complexa de agregados e ligante. Geralmente os cimentos aluminosos são usados como aglutinante. A ampla utilização do concreto como material refratário deve-se à sua relativa facilidade de uso quando comparados a materiais moldados. No entanto, esses tipos de concretos possuem a característica de serem tratados termicamente in situ, o que pode resultar em algumas desvantagens devido à sua exposição a altos gradientes de temperatura no estado estacionário.

A indústria começou a considerar as propriedades mecânicas em materiais refratários em alta temperatura esua influência no comportamento dos mesmos na década de 1980. As primeiras tentativas foram feitas em estruturas industriais, como alto forno (blast furnace), tanque de gaseificação de carvão e panelas de aço (PROMPT; OUEDRAOGO, 2008).

O comportamento apresentado pelos concretos refratários corresponde a um comportamento quase-frágil, requerendo uma descrição mecânica mais precisa incluindo os comportamentos à compressão e à tração. O comportamento mecânico está relacionado com a iniciação e desenvolvimento de fissuras (SIMONIN et al., 2002). Em diferentes temperaturas o comportamento de materiais refratários foi estudado através de ensaios mecânicos em maior parte após a queima. Foi 
observado um comportamento de abrandamento (softening) à compressão, (KATSAVOU; KROKIDA; ZIOMAS, 2012; OUEDRAOGO et al., 2011).

O conhecimento do comportamento termomecânico dos materiais refratários possibilita prever sua degradação e assim aumentar sua vida útil. Geralmente, considera-se que as propriedades mecânicas dos concretos refratários diminuem acima de $300^{\circ} \mathrm{C}$ devido a destruição da rede de produtos de hidratos de cimento associada a um aumento de porosidade (DÍAZ et al., 2008). Em temperaturas mais elevadas (acima de $1200^{\circ} \mathrm{C}$ ), os estudos realizados mostram que os refratários recuperam sua resistência através do processo de sinterização (SIMONIN et al., 2000). Processo no qual, tem um papel importante o hexaluminato de cálcio $\left(\mathrm{CA}_{6}\right)$, formado a partir de dialuminato de cálcio $\left(\mathrm{CA}_{2}\right)$ e alumina livre.

A modelagem numérica é uma abordagem atrativa para analisar o comportamento termomecânico de estruturas industriais sujeitas a cargas térmicas (OUEDRAOGO; PROMPT, 2008).

Neste trabalho estuda-se, tanto experimentalm ente como numericamente, o comportamento termomecânico de concretos refratários baseados em matrizes que contém alumina. A relação entre o comportamento mecânico e a evolução das mudanças microestruturais foi investigada na faixa de temperatura entre a temperatura ambiente até $1200^{\circ} \mathrm{C}$.

\section{1. \\ Motivação}

Concretos refratários são muito importantes em aplicações industriais e, como mencionado previamente, existe uma enorme demanda mundial para este tipo de material. Para que estes materiais sejam efetivamente utilizados é essencial que seu comportamento seja melhor compreendido e que modelos numéricos em escala de componentes sejam desenvolvidos para que aplicações estruturais possam ser analisadas e otimizadas. Em particular, sua utilização como material de revestimento em instalações sujeitas a variação térmicas precisa ser explorada. 


\section{2.}

\section{Objetivos}

O objetivo principal desta pesquisa é estudar as mudanças no comportamento termomecânico em diferentes temperaturas de concretos refratários a base de alumina em diferentes combinações de cimento aluminoso e tipos de agregados visando modelar sua aplicação como revestimentos refratários. Deseja-se investigar também o seu comportamento com a adição de fibras metálicas (aço inoxidável) de diferentes configurações e geometrias. Isso pretende-se alcançar através de um programa experimental abrangente em conjunto com uma modelagem numérica do comportamento termomecânico desses materiais em aplicações específicas.

Objetivos específicos:

- Investigar experimentalmente o comportamento químico e mecânico de concretos refratários com diferentes composições de alumina (51, 71 e $90 \mathrm{wt} . \%)$ sob a influência de temperatura, i.e., submetidos a temperaturas entre 25 e $1200^{\circ} \mathrm{C}$.

- Realizar simulações numéricas do processo de aquecimento (até $1200^{\circ} \mathrm{C}$ ) para diferentes combinações de sistemas de revestimentos refratários aplicados em camadas usando os concretos refratários estudados neste trabalho.

- Estudar o efeito da adição de fibras de aço inoxidável na matriz de concreto refratário no comportamento termomecânico refratários em diferentes temperaturas $\left(25-1000^{\circ} \mathrm{C}\right)$.

\section{3.}

\section{Estrutura do trabalho}

O capítulo 2 apresenta a revisão bibliográfica realizada sobre o comportamento mecânico e químico de concretos refratários sob o efeito de diferentes temperaturas, concretos refratários reforçados com fibras e modelagem numérica de concretos refratários. 
O capítulo 3 apresenta as metodologias e as análises dos resultados obtidos nos principais tópicos estudados.

O capítulo 4 apresenta as conclusões e sugestões para trabalhos futuros.

Os anexos foram escritos em forma de artigo científico e vinculados aos capítulos 3 de metodologia e resultados.

O Artigo A foi publicado no Journal Construction and Building Materials. O título do artigo em português é: "A influência do teor de alumina no comportamento químico e mecânico de concretos refratários em diferentes temperaturas".

O Artigo B, submetido no periódico International Journal of Applied Ceramic Technology e aguarda aceitação por parte dos revisores, corresponde à: "Modelagem numérica do comportamento termomecânico de revestimentos de concretos refratários".

O Artigo C abrange sobre o "Comportamento termomecânico de concretos refratários reforçados com fibras de aço inoxidável: analises experimental e numérica". 


\section{2 \\ Revisão Bibliográfica}

\subsection{Comportamento de concretos refratários com a temperatura}

Os materiais refratários antes do início do século 20 eram feitos em forma de tijolos cozidos. Hoje, mais aplicações industriais requerem materiais refratários monolíticos ou monolíticos desenvolvidos por outros métodos. A produção de refratários monolíticos apareceu em 1950, no Japão, e cresceu até 1965. Inicialmente era projetado para reparos em pequena escala. Em 1988, sua produção já representava $45 \%$ do volume total de refratário (SIMONIN, 2000). Os concretos refratários monolíticos são usualmente compostos de cimento refratário, com um teor alto de alumina $\left(\mathrm{Al}_{2} \mathrm{O}_{3}\right)$ entre 50 e $90 \%$, agregados compatíveis que suportam alta temperatura, e um teor mínimo de água. Outros constituintes, tais como aditivos são incluídos em pequenas quantidades a fim de melhorar a capacidade de fluidez ou de outras propriedades físicas ou químicas da mistura (PROMPT; OUEDRAOGO, 2008). A vantagem desses concretos é a sua "flexibilidade" nas aplicações de revestimentos. Porém, a ausência de juntas que aliviam as tensões térmicas, pode levar a uma importante falha do revestimento, tais como fissuração e vazão do fluido. As aplicações são encontradas em industrias de grande porte,

geralmente estruturas submetidas a cargas térmicas cíclicas. Por exemplo, os concretos refratários são utilizados como revestimentos em altos-fornos (blast furnace), em tanques de aço fundido (steelmaking ladle), em torres de reatores nucleares, etc.

\subsection{1.}

\section{Comportamento mecânico}

A variação do comportamento mecânico com o aumento da temperatura dos concretos refratários tem sido estudado por diferentes pesquisadores 
(OUEDRAOGO et al., 2011; PROMPT; OUEDRAOGO, 2008; SIMONIN et al., 2002). Os compósitos estudados variam em diferentes tipos de matrizes refratárias utilizando cimentos aluminosos e diversos tipos de agregados. Experimentos à compressão uniaxial, tração, flexão e testes de descarregamento de cargas cíclicas foram realizados para descrever o comportamento. A maioria dos ensaios são realizados à temperatura ambiente, após a queima dos concretos, obtendo as propriedades residuais. Poucos ensaios são executados in situ, ou seja, ensaios à quente. As temperaturas dos diferentes experimentos variam desde a temperatura ambiente $25^{\circ} \mathrm{C}$, até $1400^{\circ} \mathrm{C}$. Testes mecânicos em materiais após a queima revelaram a ocorrência de mudanças significativas nas propriedades após a exposição a altas temperaturas que serão mostradas nos seguintes trabalhos relacionados.

O estudo do comportamento mecânico de concretos aluminosos usados em plantas siderúrgicas encontrados na literatura (SIMONIN et al., 2002) mostraram um comportamento não linear pronunciado, tanto à compressão quanto à tração, com uma fratura frágil. O comportamento à flexão é caracterizado por danos, primeiro difusos e depois mais localizados, o que finalmente leva à formação de uma macro-fissura, como detalhado na Figura 2.1. O limite de danos é muito baixo em tração (5\% da carga máxima) é maior na compressão (40\% da carga máxima), isto indica o limite de proporcionalidade da curva.

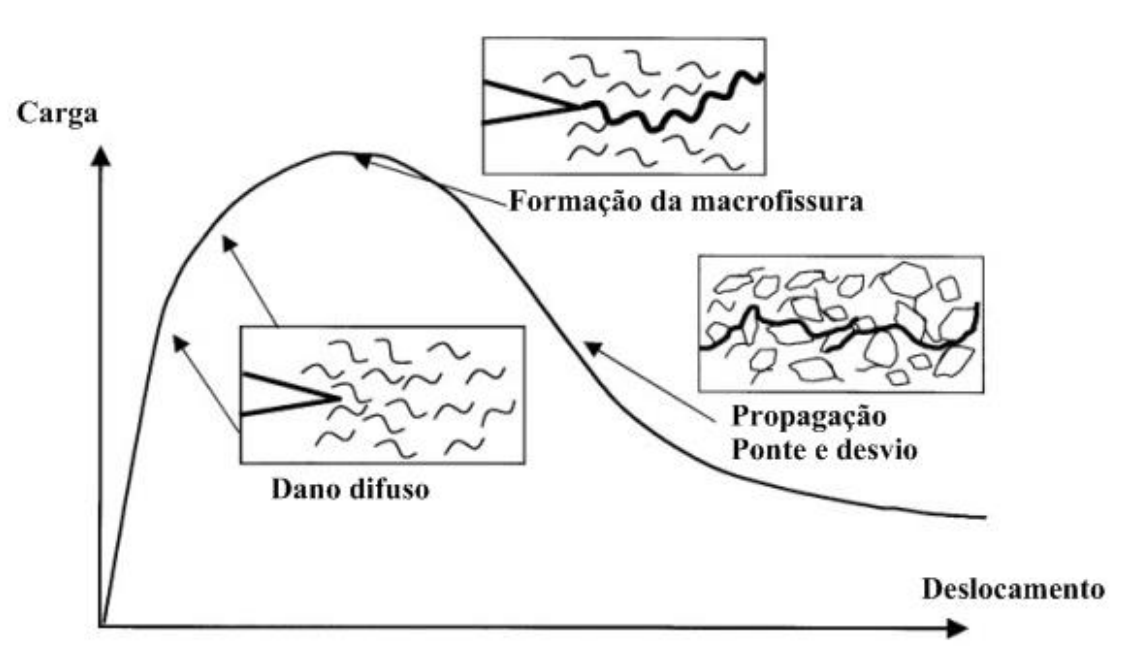

Figura 2.1 - Desenvolvimento de danos em um ensaio a flexão com entalhe (SIMONIN et al., 2002) 
A Figura 2.2 mostra uma resposta uniaxial típica de um material refratário (DAMHOF; BREKELMANS; GEERS, 2008). Após o aumento da temperatura, ocorre uma transição de um comportamento frágil para um mais quase-frágil. A parte da curva pós-elástica que precede à falha final é maior. Também a deformação na qual o pico de tensão ocorre, aumenta com a temperatura. Outras mudanças características ao aumento da temperatura resultam em menores resistências à compressão e um menor módulo de elasticidade.

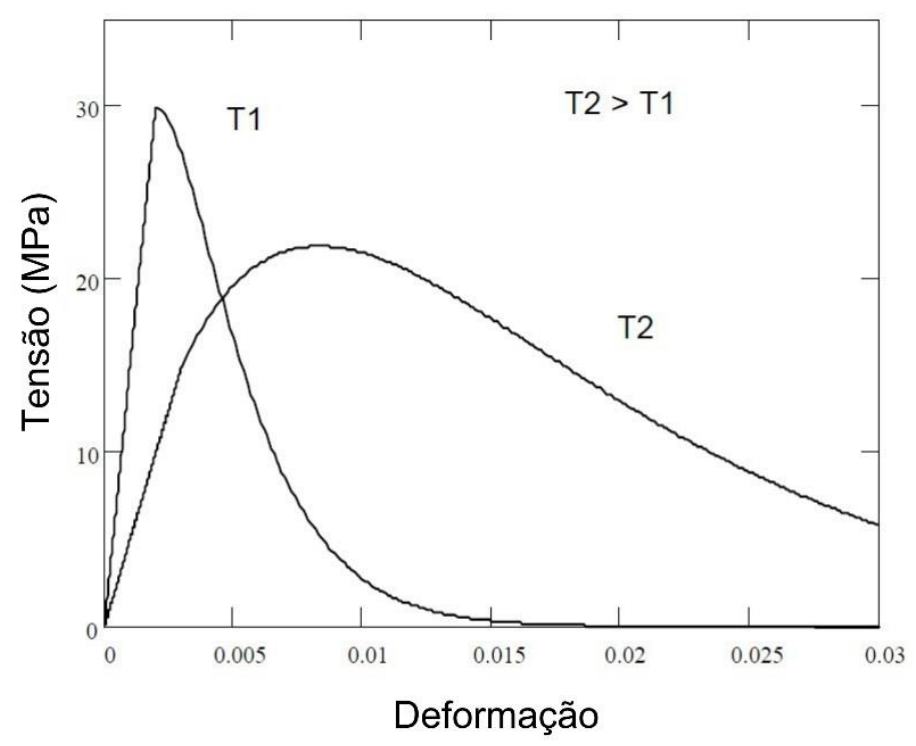

Figura 2.2 - Resposta mecânica de um refratário típico de alumia e silicato em função da temperatura (DAMHOF; BREKELMANS; GEERS, 2008).

Da temperatura ambiente até $1000^{\circ} \mathrm{C}$, o comportamento mecânico destes materiais permanece quase frágil. Em temperaturas mais elevadas $\left(>1000^{\circ} \mathrm{C}\right)$, alguma visco-plasticidade ocorre e domina o comportamento.

De acordo com a literatura (DÍAZ et al., 2008) o comportamento de concretos aluminosos à compressão em diferentes temperaturas foi representado na Figura 2.3. Em todos os casos, obtém-se um comportamento não-linear associado ao desenvolvimento de dano. No entanto, o comportamento não linear mais pronunciado foi obtido para os materiais tratados na faixa de temperatura intermediária, entre 450 e $1200^{\circ} \mathrm{C}$, isto é, exibiram o maior dano inicial. 


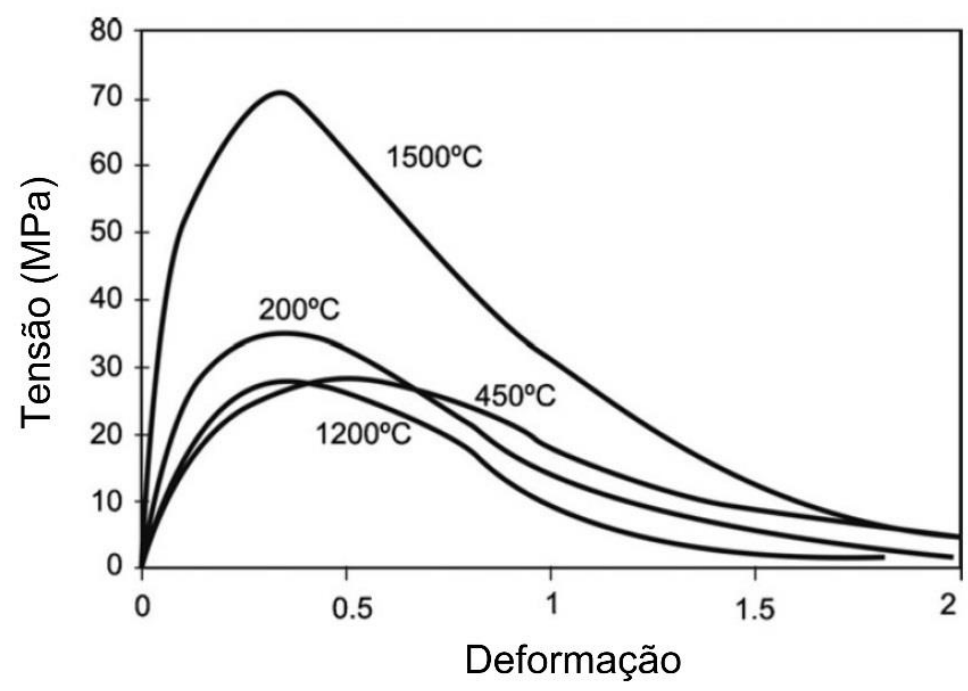

Figura 2.3 - Testes de compressão em concreto refratário aluminoso após a queima em diferentes temperaturas. (DÍAZ et al., 2008)

O trabalho realizado por (OUEDRAOGO et al., 2011) sobre o comportamento à compressão avaliou dois tipos de concretos refratários com a mesma composição da matriz, mas com diferentes agregados (andalusita e bauxita) submetidos de testes de compressão uniaxial realizados em condições de temperatura in situ. Para temperaturas entre $20-1200^{\circ} \mathrm{C}$ a evolução do comportamento global dos materiais foi de quase frágil a viscoso. A evolução foi correlacionada com observações macroscópicas na microestrutura por SEM (microscopia eletrônica de varredura). A Figura 2.4 mostra a evolução da resistência à compressão em função da temperatura para os dois concretos refratários. Os dois materiais apresentaram um comportamento semelhante com o aumento da temperatura. No entanto, o concreto refratário à base de agregado de bauxita apresentou resistências mais elevadas do que o concreto com agregado de andalusita, exceto para $1200^{\circ} \mathrm{C}$. 

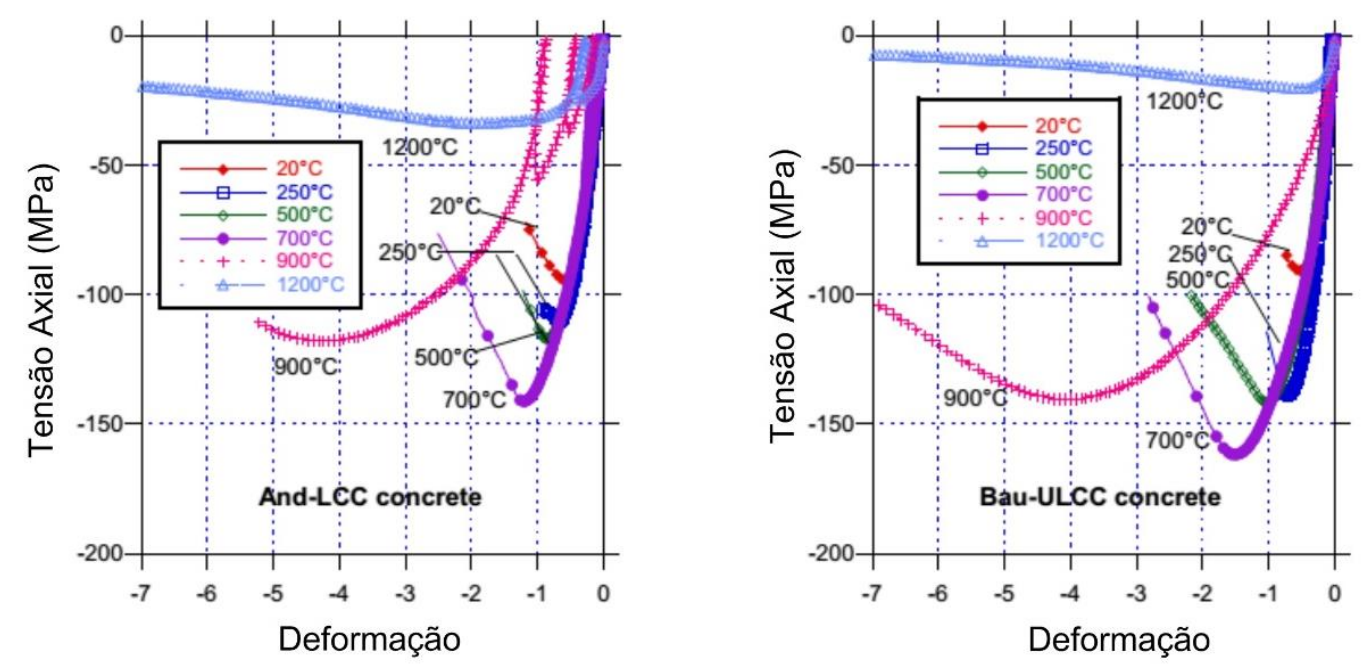

Figura 2.4 - Curvas tensão-deformação à compressão uniaxial de concretos refratários com andalusita e bauxita a diferentes temperaturas. (OUEDRAOGO et al., 2011)

Os ensaios de tração são escassos, por serem de execução mais complexa. Uma das investigações sobre o comportamento à tração (KAKROUDI et al., 2009) para os dois tipos de concretos similares aos vistos anteriormente (com tipos de agregados de andalusita e bauxita). Os resultados (Figura 2.5) ressaltaram a alta rigidez do concreto a base de bauxita e a importante redução do módulo de elasticidade (E) após o tratamento térmico no caso do concreto a base de andalusita.
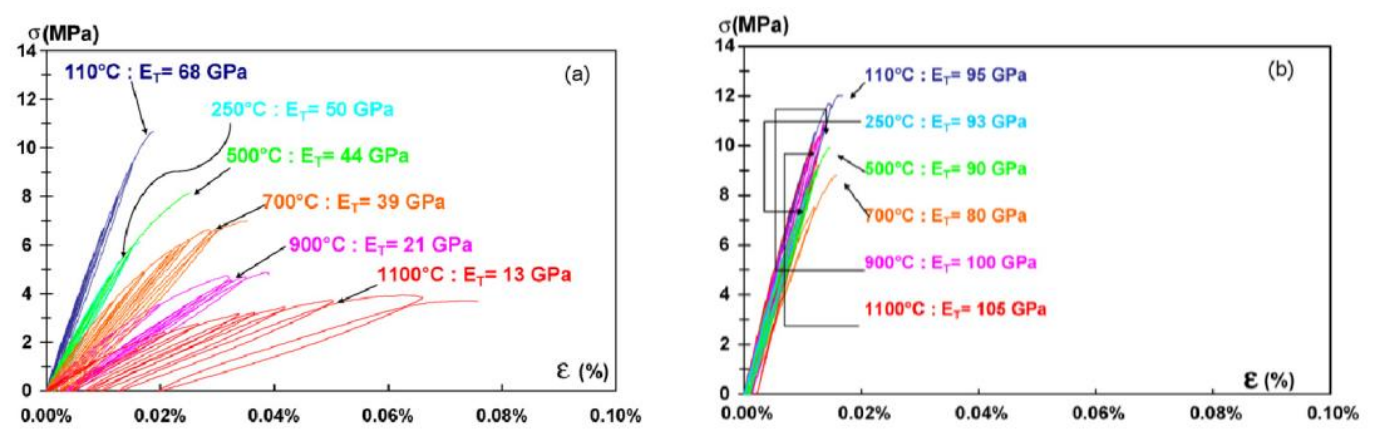

Figura 2.5 - Comportamento à tração em diferentes temperaturas dos concretos refratários (a) agregado andalusita (b) agregado bauxita

A evolução das propriedades mecânicas dos concretos refratários com a temperatura reportada pelos diferentes autores resulta em uma difícil comparação uma vez que esses autores usaram cimentos diferentes, agregados de diferentes 
tipos, ciclos de queima distintos ou variações nos testes mecânicos. No entanto, pode-se observar a evolução geral destas propriedades com a temperatura e qual é o comportamento desejado. Em relação às propriedades mecânicas do cimento unicamente, a maioria dos autores observa a mesma evolução, ou seja, uma diminuição na resistência entre $200^{\circ} \mathrm{C}$ e $300^{\circ} \mathrm{C}$, uma variação regular até $1000^{\circ} \mathrm{C}$, para temperaturas mais elevadas um aumento acentuado é observado na sinterização.

Ensaios a quente e a frio apresentam resultados diferentes para um mesmo material, especialmente quando a temperatura é bastante alta (acima de $600^{\circ} \mathrm{C}$ ). De acordo com a Figura 2.6, a resistência à tração após o aquecimento exibiu uma diminuição significativa devido à microfissuração gerada pelas fases de desidratação do cimento (MARZAGUI, 2005). A diferença entre os ensaios à temperatura ambiente e os ensaios à quente, neste caso, mostraram que o resultado da resistência à tração é mais importante na faixa de $500-700^{\circ} \mathrm{C}$. Observou-se até $700^{\circ} \mathrm{C}$ um comportamento frágil. Entretanto a partir de $900^{\circ} \mathrm{C}$, foram também observadas grandes deformações plásticas e fissuras consideráveis, o que representa uma mudança drástica no material. Para a temperatura próxima a $1000^{\circ} \mathrm{C}$, correspondente à faixa temperatura de trabalho, até $1200^{\circ} \mathrm{C}$ essa diferença mostrase menor.

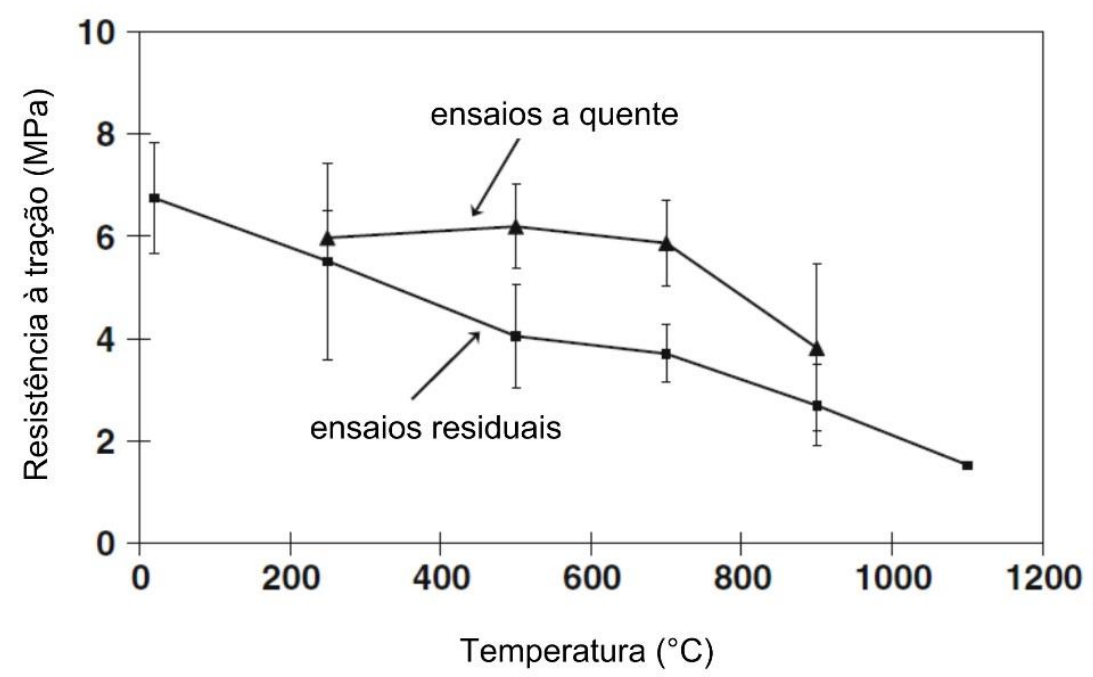

Figura 2.6 - Temperatura ambiente e resistência à tração a alta temperatura do concreto refratário And-LCC após tratamentos térmicos. (MARZAGUI, 2005) 
A Figura 2.7 apresenta resultados de módulo de ruptura de concreto refratário com alto teor de alumina em diversas temperaturas para ensaios a quente e após arrefecimento. Para os ensaios a quente ou in situ observa-se que a tendência do módulo de ruptura é diminuir o valor com o aumento da temperatura de queima, com exceção do aumento obtido em torno de $800^{\circ} \mathrm{C}$, voltando a diminuir para temperaturas superiores. Nos ensaios residuais a temperatura ambiente, nota-se que até próximo a $800^{\circ} \mathrm{C}$ o módulo de ruptura também se reduz com o aumento da temperatura. No entanto, a partir de $800^{\circ} \mathrm{C}$, o aumento da temperatura de queima se traduz em um aumento progressivo do módulo de ruptura, com um aumento substancial em torno de $1400^{\circ} \mathrm{C}$ que corresponde ao desenvolvimento de ligações cerâmicas nos concretos refratários (WYGANT e BUKLEY, 1954 apud BAZANT et. al 1996).

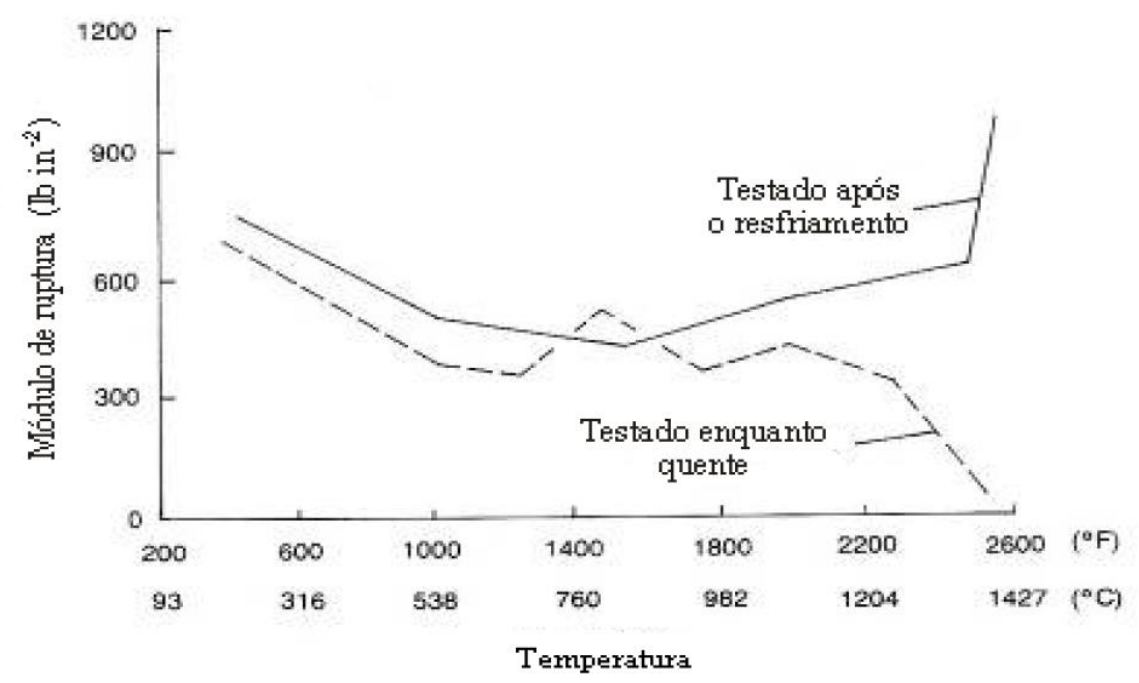

Figura 2.7 - Variação do Módulo de ruptura de concretos refratários com alto teor de alumina queimados em diferentes temperaturas para ensaios a quente $\mathrm{e}$ residual (WYGANT e BUKLEY, 1954 apud BAZANT et. al 1996).

O conhecimento do comportamento sobre o dano desses tipos de materiais é fundamental para uma melhor compreensão dos mecanismos que induzem à ruptura final. A Figura 2.8 mostra o dano identificado como decorrência entre agregado e matriz, e microfissuras na matriz que leva a redução do módulo de elasticidade. O comportamento do material com bauxita para $700^{\circ} \mathrm{C}$ é semelhante ao material com 
andalusita. Em todos os casos, o de bauxita é um concreto menos danificado após o arrefecimento em relação ao concreto de andalusita (KAKROUDI et al., 2008).
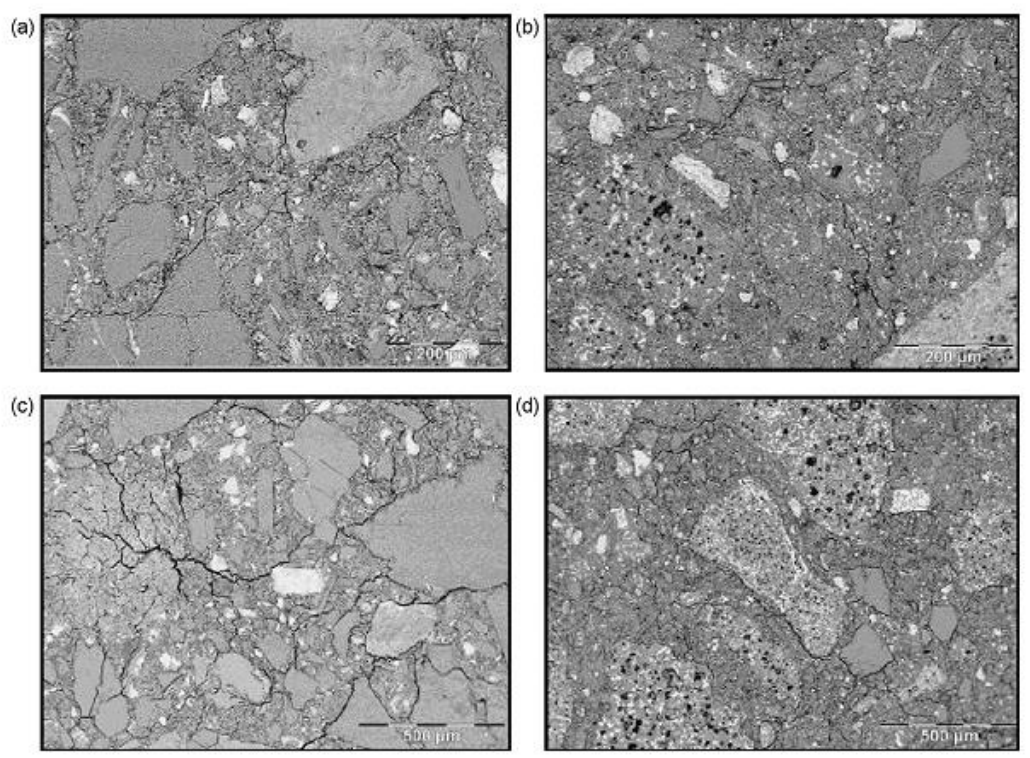

Figura 2.8 - Identificação do dano em ambos os tipos de concreto após tratamentos térmicos (a) concreto à prova de fogo Andalusita a $700^{\circ} \mathrm{C}(\mathrm{b})$ concreto à prova de fogo Bauxita $\mathrm{a} 700^{\circ} \mathrm{C}$ (c) concreto à prova de fogo Andalusita a $900^{\circ} \mathrm{C}$ (d) concreto à prova de fogo Bauxita a $700^{\circ} \mathrm{C}$ (KAKROUDI et al., 2008).

\subsection{2.}

\section{Comportamento químico}

Um exemplo típico da composição química de um material refratário é apresentado na Tabela 2.1. As percentagens em massa de alumina $\left(\mathrm{Al}_{2} \mathrm{O}_{3}\right)$ e sílica $\left(\mathrm{SiO}_{2}\right)$ governam em grande parte as características do material. Os concretos refratários de alumina e silicato são usados em ambientes de alta temperatura devido à sua resistência em alta temperatura combinada com uma resistência razoável ao choque térmico (DAMHOF; BREKELMANS; GEERS, 2008).

Tabela 2.1 - Composição química típica de concretos refratários de alumina

\begin{tabular}{lc}
\hline Componentes (\%w) & $\mathrm{A51}$ \\
\hline $\mathrm{Al}_{2} \mathrm{O}_{3}$ & 59.50 \\
\hline $\mathrm{SiO}_{2}$ & 37.60 \\
\hline
\end{tabular}




\begin{tabular}{ll}
\hline $\mathrm{CaO}$ & 0.18 \\
\hline $\mathrm{Fe}_{2} \mathrm{O}_{3}$ & 1.26 \\
\hline $\mathrm{TiO}_{2}$ & 0.37 \\
\hline
\end{tabular}

Estes materiais são compostos principalmente de mulita $\left(3 \mathrm{Al}_{2} \mathrm{O}_{3} .2 \mathrm{SiO}_{2}\right) \mathrm{com}$ algumas fases vítreas de $\mathrm{SiO}_{2}$. Essas fases vítreas começam a suavizar quando se aproximam a sua temperatura de transição vítrea levando a um comportamento visco plástico a altas temperaturas (AKSEL, 2003). Normalmente, esta temperatura de transição vítrea está bem abaixo da temperatura de uso final do material refratário que é acima de $900^{\circ} \mathrm{C}$.

As mudanças de fase que ocorrem no concreto refratário a base de cimento de aluminato de cálcio (CAC) quando aquecido foram investigados por vários autores (AUVRAY; GAULT; HUGER, 2008; MUNOZ; TOMBA MARTINEZ, 2012; POLLMANN, 2012). O processo de reações químicas no cimento inicia na hidratação e a partir dos hidratos metaestáveis. $\mathrm{CAH}_{10}$ e $\mathrm{C}_{2} \mathrm{AH}_{8}$ são transformados em $\mathrm{C}_{3} \mathrm{AH}_{6}$ e gibbsite $\mathrm{Al}(\mathrm{OH})_{3}$ hidratos muito mais estáveis, isto consiste em uma conversão lenta a baixa temperatura $\left(\approx 50^{\circ} \mathrm{C}\right)$ e mais rápida a $80^{\circ} \mathrm{C}$. $\mathrm{O}$ hidrato de $\mathrm{CAH}_{10}$ e o gel de alumina desidratam em torno de $100^{\circ} \mathrm{C}$ e $\mathrm{C}_{2} \mathrm{AH}_{8}$ em torno de $200^{\circ} \mathrm{C}$. Este processo é acompanhado por uma contração e uma diminuição de densidade apreciável, como resultado da transição da fase $\mathrm{CAH}_{10}$ para a fase $\mathrm{C}_{3} \mathrm{AH}_{6}$ e o gel de alumina em gibbsita cristalina. Estes se decompõem entre $300^{\circ} \mathrm{C}$ e $400^{\circ} \mathrm{C}$ para formar aluminatos de cálcio amorfos, alumina amorfa e diásporo (AlO.OH). Este processo é novamente acompanhado de uma forte contração e uma diminuição apreciável de densidade. Entre $400^{\circ} \mathrm{C}$ e $900^{\circ} \mathrm{C}$, o diásporo decompõe e produz o gel de alumina que garante a nucleação da fase $\mathrm{C}_{12} \mathrm{~A}_{7}$. Uma leve contração e diminuição da densidade é observada. Se houver cal hidratada, esta torna-se cal livre em torno de $440^{\circ} \mathrm{C}$, que reage com alumina para formar ainda mais $\mathrm{C}_{12} \mathrm{~A}_{7}$. A alumina está presente no cimento, mas também pode vir da adição de agregados finos na composição do concreto. Cerca de $900^{\circ} \mathrm{C}, \mathrm{C}_{12} \mathrm{~A}_{7}$ combina-se com alumina para formar o mono-aluminato de cálcio CA. Ocorre uma ligeira contração e um aumento da densidade. $\mathrm{A} 1000^{\circ} \mathrm{C}$, o CA reage com alumina para dar $\mathrm{CA}_{2}$ que, por sua vez, combina-se com alumina em torno de $1300^{\circ} \mathrm{C}$ para dar $\mathrm{CA}_{6}$, fase muito estável com propriedades interessantes (alta resistência mecânica a altas temperaturas, bom comportamento contra choques térmicos e resistência à corrosão 
do aço) (NONNET; LEQUEUX; BOCH, 1999). A $1300^{\circ} \mathrm{C}$ ocorre a sinterização em fase líquida, o que leva a uma forte contração da material e aumento de densidade (TERZIĆ; PAVLOVIĆ, 2009).

Em temperaturas ainda mais elevadas $\left(>1300^{\circ} \mathrm{C}\right)$, a ligação entre as partículas de alumina e $\mathrm{CA}_{6}$ torna-se mais forte. A $1500^{\circ} \mathrm{C}$, a microestrutura aparece uniformemente sinterizada (NONNET; LEQUEUX; BOCH, 1999). A Figura 2.9 mostra uma visão completa de todo o processo de hidratação, desidratação e sinterização de um concreto refratário a base de alumina contendo CAC (Calcium Aluminate Cement).As faixas de temperatura onde ocorrem a formação e transformação de cada fase são também indicadas na figura (RIBEIRO; RODRIGUES, 2010).

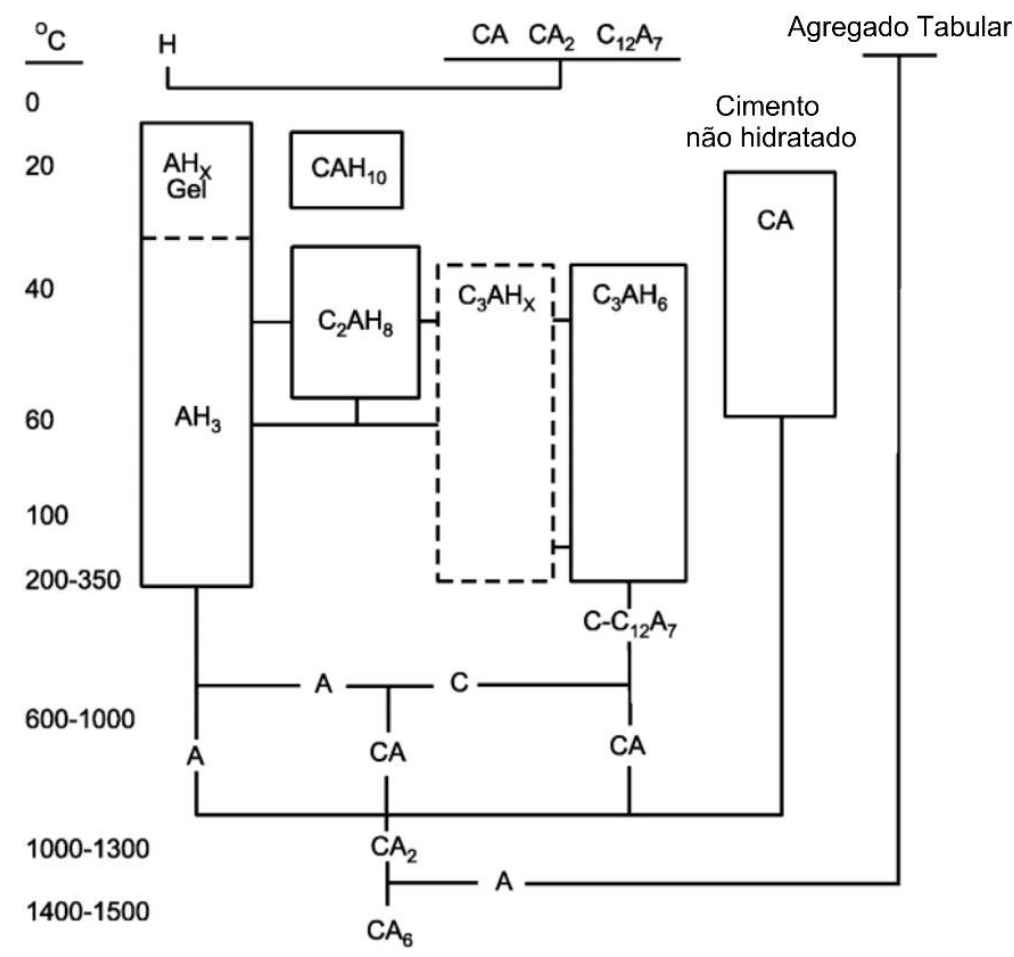

Figura 2.9 - Transformações durante a queima de concretos refratários de alumina contendo CAC.

Muitas teorias tentam explicar a perda de resistência mecânica, em termos de mudanças na estrutura cristalina que acompanham a conversão de cimentos de aluminato de cálcio (CAC). Alguns autores afirmam que os cristais cúbicos de $\mathrm{C}_{3} \mathrm{AH}_{6}$ são menos resistentes do que os pequenos cristais hexagonais $\mathrm{CAH}_{10}$ porque 
possuem mais deslocamentos em sua estrutura. Outros consideram que os cristais $\mathrm{C}_{3} \mathrm{AH}_{6}$ não levam a uma estrutura estável, ao contrário de $\mathrm{CAH}_{10}$ (DE AZA et.al., 2000). Outros atribuem a perda de resistência mecânica ao gel de alumina que não atua mais como aglutinante quando se cristaliza. Em contraste, (CHATERJI et.al.,1998) mostraram como uma pasta $\mathrm{CA} / \mathrm{CAH}_{10}$ pode adquirir toda a sua resistência sem a presença deste gel.

O estudo de (NONNET; LEQUEUX; BOCH, 1999) mostrou que o módulo de elasticidade de concretos aluminosos diminui durante o processo de conversão de $\mathrm{CAH}_{10}$ em $\mathrm{C}_{3} \mathrm{AH}_{6}$ entre a temperatura ambiente e $150^{\circ} \mathrm{C}$. Por outro lado, como esta conversão é acompanhada por uma liberação de moléculas de água, ainda partículas de cimento de CA anidro são hidratados: há então um ligeiro aumento no módulo de elasticidade entre $150^{\circ} \mathrm{C}$ e $200^{\circ} \mathrm{C}$ (Figura 2.10).

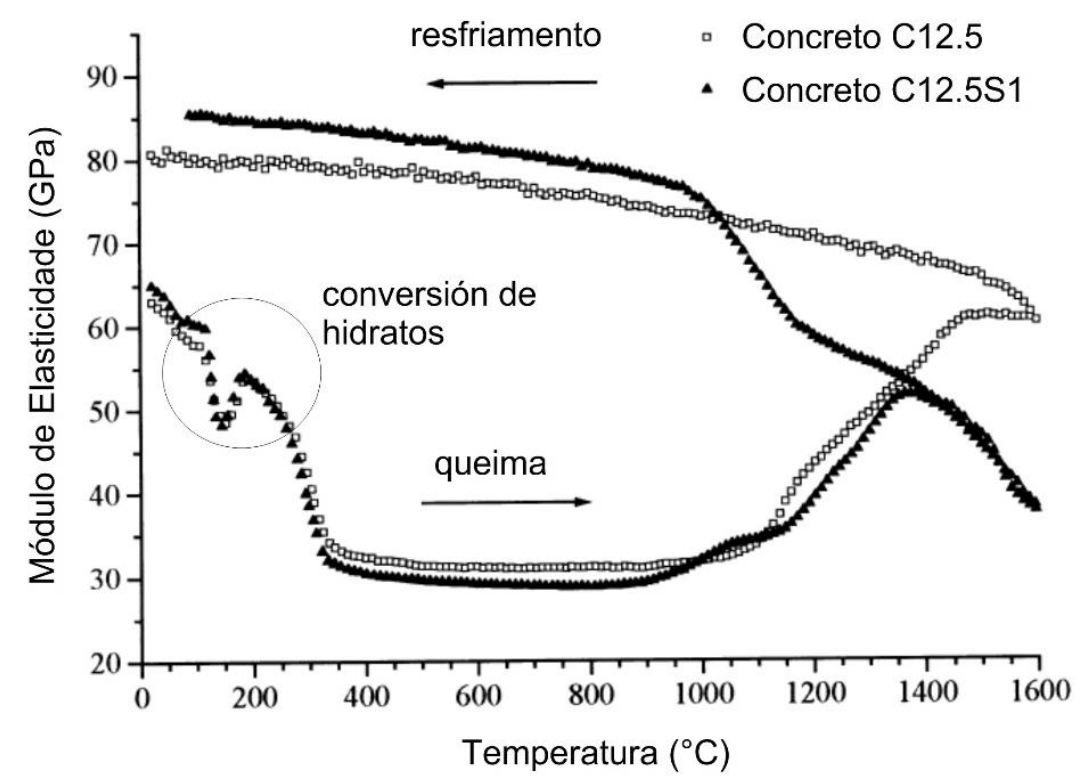

Figura 2.10 - Evolução do módulo de elasticidade de um concreto refratário aluminoso coma temperatura (NONNET; LEQUEUX; BOCH, 1999)

Em conclusão, a conversão dos hidratos cristalinos e do gel de alumina transforma a morfologia da matriz e sua porosidade. Alguns autores afirmam que o aumento da porosidade causada por essas transformações é responsável pela perda de resistência mecânica. Outros atribuem ao fenômeno da conversão e transformação do gel de alumina. 


\section{2. \\ Concretos refratários reforçados com fibras metálicas}

Os concretos refratários como descrito são caracterizados por uma baixa resistência à tração e uma fratura frágil ou quase frágil. As fibras de aço são comumente usadas na indústria refratária para reforçar os concretos de alta temperatura. Também são utilizadas fibras de vidro e fibras cerâmicas. Os efeitos das fibras dependem principalmente do material da fibra, da forma e dimensões das fibras e da fração volumétrica no concreto. No caso do concreto refratário reforçados com fibras (FRRC), as temperaturas de queima também influenciam no seu comportamento termomecânico.

(DONVAL et al., 2011) investigou os efeitos de um reforço de fibras metálicas sobre o comportamento termomecânico na flexão de quatro pontos de um concreto refratário à base de carboneto de silício. Isto para temperaturas entre a temperatura ambiente e $400^{\circ} \mathrm{C}$. Os resultados mostraram que o reforço de fibras tem um efeito benéfico tanto no comportamento pré-pico quanto no comportamento pós-pico do concreto refratário. As fibras curtas geralmente permitem aumentar a capacidade de deformação dos concretos, modificando a propagação das microfissuras e atrasando o início das macrofissuras.

Os concretos refratários reforçados com fibras (FRRC) tem sido estudados para propor soluções para fabricação de matrizes para alta temperatura (MAZZONI; BERNHART; CUTARD, 2012). Duas classes de fibras cerâmicas à base de alumina foram investigadas como soluções de reforço para um concreto refratário de andalusita e para temperaturas superiores a $900^{\circ} \mathrm{C}$. Os testes mecânicos de alta temperatura foram realizados até $1200^{\circ} \mathrm{C}$ em condições de flexão de quatro pontos. Os resultados mostram uma melhora significativa nas propriedades mecânicas e de fluência até $1100^{\circ} \mathrm{C}$ em comparação com refratários não reforçados.

Pouca informação está disponível na literatura sobre o desempenho do concreto refratário reforçado com fibras curtas de aço orientadas aleatoriamente na mistura. Como mencionado, muitos fatores influenciam o comportamento termomecânico dos compósitos, sendo o efeito da geometria das fibras no concreto refratário um fator de importância. Os fabricantes e usuários de refratários 
reforçados com fibras, que o uso de fibra de aço "padrão", mais econômicas, são o suficientemente viáveis, sendo que precisa-se de novas soluções e estudos para otimizar o desempenho desses compósitos refratários (MEDDAH; BELAGRAA; BEDDAR, 2015). A indústria também é reservada sobre as informações obtidas neste campo de refratários com adição de fibras.

\section{3. Modelagem do comportamento termomecânico de concretos}

A degradação dos materiais refratários em estruturas industriais resulta em um problema significativo para os processos produtivos. É reconhecido que as tensões térmicas e o ciclo de tensões térmicas desempenham um papel importante na degradação desses materiais, porém a quantificação deste fenômeno continua em aberto. Para entender os mecanismos térmicos de falha refratária, é fundamental conhecer o histórico de temperatura do material refratário, a resposta de tensão associada e o eventual dano no material.

Os materiais refratários, devido à sua natureza frágil, são suscetíveis a rachaduras sob condições de elevadas taxas de transferência de calor ou variações rápidas na transferência de calor. Para evitar a falha por fissuração do concreto refratário, é importante conhecer a magnitude da tensão térmica quando os refratários são submetidos às condições operacionais industriais. Tendo isto em vista, fundamentos teóricos das tensões térmicas e trabalhos relacionados na área de modelagem térmica, modelagem de tensão térmica e danos refratários são discutidos a seguir.

\subsection{1.}

\section{Tensões térmicas}

$\mathrm{O}$ aquecimento e arrefecimento induz a tensão térmicas em refratários. A distribuição e a severidade destas tensões também depende da severidade do aquecimento e do resfriamento. (TSIBIN et al., 1988) ilustraram isso com a ajuda de um diagrama esquemático (Figura 2.10) que mostra um material refratário passando por três diferentes taxas de aquecimento. Esta situação é semelhante ao pré-aquecimento típico do revestimento refratário. A Figura 2.10 (a) mostra a 
representação esquemática dos gradientes de temperatura gerados em um revestimento quando submetido a uma condição de contorno convectivo. Os símbolos $\tau_{1}, \tau_{2}$ e $\tau_{3}$ indicam o tempo em que o fluxo de calor convectivo foi aplicado. Pode-se ver que o gradiente térmico fica mais íngreme de $\tau_{3}$ a $\tau_{1}$. A Figura 2.10 (bd) mostra os perfis de tensão térmica correspondentes aos tempos $\tau_{1}, \tau_{2}$ e $\tau_{3}$. A zona I e a zona III são regiões que apresentam tensões de compressão, ao passo que a zona II é uma região com tensões de tração. A medida que os gradientes térmicos (em $\tau_{1}, \tau_{2}$ ou $\tau_{3}$ ) são pequenos afastando-se da face quente, as magnitudes da tensão térmica (compressão ou de tração) são também pequenas, longe da face quente.

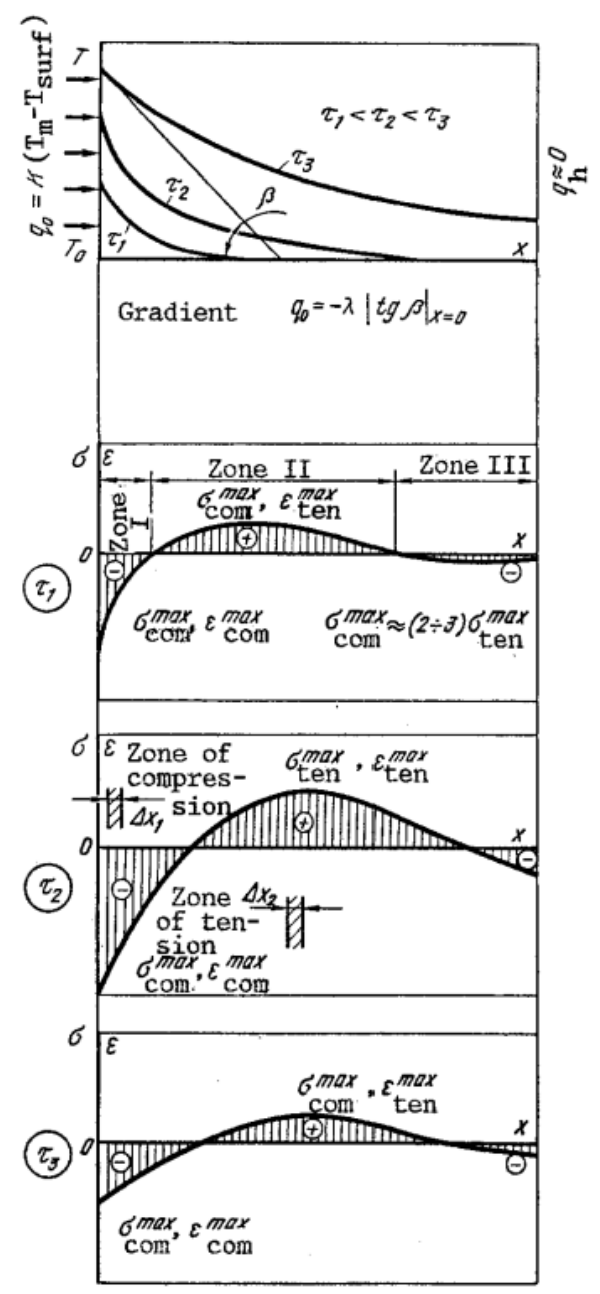

(a)

(b)

(c)

(d)

Figura 2.11 - Representação das tensões térmicas um concreto com vários gradientes de temperaturas

O que é esperado do material em termos de comportamento para garantir bom desempenho do revestimento é magnitude de tensões térmicas abaixo da resistência a tração do material. 
Alguns trabalhos foram realizados sobre a quantificação das tensões térmicas em materiais de revestimento para várias instalações, reatores, altos-fornos, conchas de aço (steel ladles). NIKIFOROV and PRIKHOD'KO (2005) tentaram especificar taxas de aquecimento seguras para revestimentos refratários para conchas de aço com base nos cálculos de tensões térmicas. Investigaram experimentalmente a variação térmica na superfície interna do revestimento durante o aquecimento e calcularam numericamente a variação de temperatura através da espessura do revestimento. As tensões térmicas foram calculadas com base nesse perfil de temperatura, assumindo o comportamento do material linear elástico com propriedades de materiais independentes de temperatura.

A Figura 2.11 mostra os perfis térmicos $(\mathrm{T})$ e de tensão térmicas $(\sigma)$ calculados ao longo da espessura do revestimento. Os números sobre as curvas mostram o tempo (no formato "horas: minutos") após o início do aquecimento. Sob estas condições, as tensões são compressivas perto da extremidade quente e passando por uma transição para tensões de tração a medida que se afastam da extremidade quente. Os autores assumiram que as tensões de tração e compressão do material são respectivamente de $25 \mathrm{MPa}$ e $40 \mathrm{MPa}$. Eles previram que a fissuração ocorreria no material uma vez que as tensões excedessem esses limites.

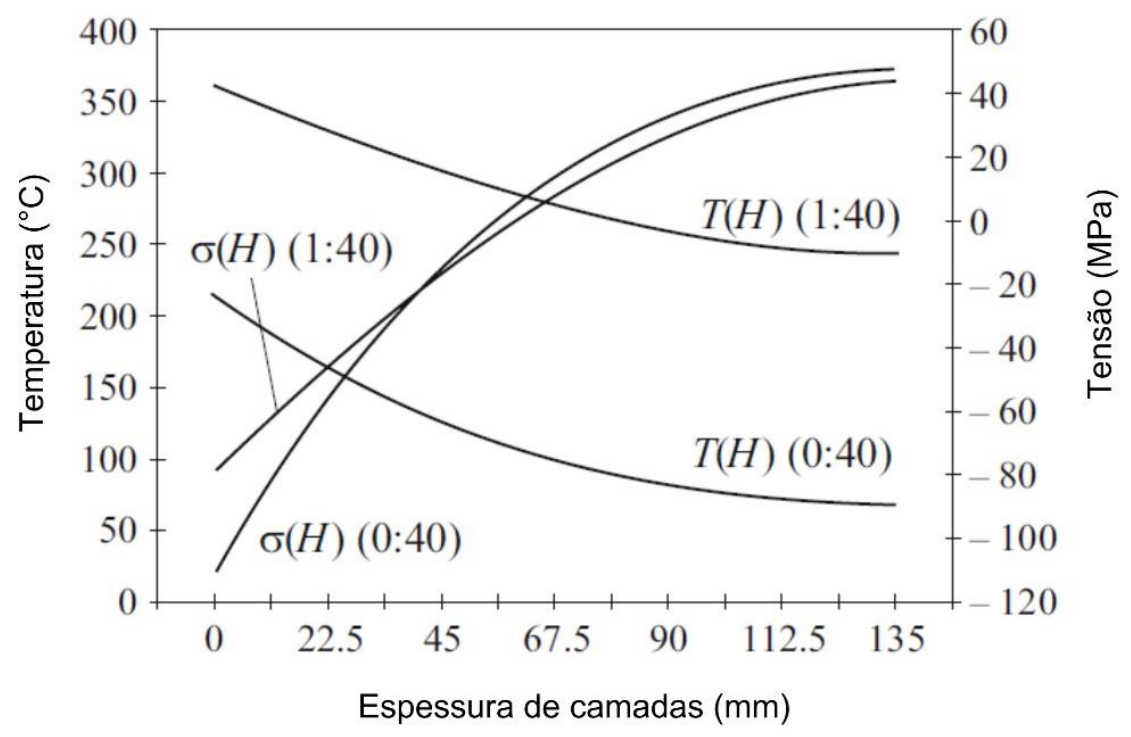

Figura 2.12 - Tensão e temperatura em função da espessura da camada no instante de tempo 0:40 e 1:40. 
(LIANG et al., 2007a) tentaram quantificaram as tensões geradas no revestimento de um tanque gaseificador industrial considerando fatores térmicos e químicos. Neste trabalho os autores assumiram o comportamento elasto-plástico dos refratários de alumina utilizados na instalação. Um modelo baseado em mecânica de danos contínuos é apresentado para analisar o comportamento de falha do revestimento refratário do gaseificador em ambientes reativos e de alta temperatura usando o método dos elementos finitos. Realizaram uma previsão da influência de fatores relacionado ao processo na distribuição de tensão no refratário. A reação química do produto causa o dano mais compressivo na estrutura refratária. Também ocorreram danos nas camadas da estrutura refratária devido ao dano de tração. A tolerância de expansão afeta o dano da estrutura refratária. Isto é, o dano de tração pode ser reduzido ao permitir uma expansão maior. O dano de compressão não depende do limite de expansão fornecido pela camada de fibra.

(GRUBER; ANDREEV; HARMUTH, 2004) desenvolveram um modelo matemático axissimétrico baseado no método de elementos finitos (MEF) para um forro de alto forno que empregou um material refratário. Eles assumiram propriedades dos materiais dependentes da temperatura e usaram um critério de falha plástica de Von Mises para a refratário e o modelo de plasticidade de DruckerPrager para o refratário moldado. O trabalho mostrou que a espessura e compressibilidade do refratário analisado são parâmetros fundamentais para minimizar a tensão de compressão nos tijolos de corundum do revestimento de trabalho que está em contato com o aço fundido.

Grande parte dos trabalhos acima mencionados assume um comportamentosimplista (elástico ou elástico-plástico) para os refratários e tenta capturar as condições ideais do processo, sendo o objetivo principalevitar fissuras/rachaduras com base na magnitude prevista das tensões térmicas. No entanto, a fissuração do refratário depende de muitos fatores. A próxima seção trabalhos relacionados à modelagem do dano em materiais refratários. 


\subsection{2. \\ Modelagem do dano do concreto}

A classificação "quase frágil" dos concretos refratários indica que o material não é completamente quebradiço e que a mecânica de fratura elástica linear não se aplica. Uma zona de fratura significativamente maior ocorre em materiais quase frágeis em comparação com os materiais frágeis. A Figura 2.12 mostra esquematicamente a distribuição de tensão ao longo de uma fissura nesses materiais. A área dentro da elipse é chamada de zona do processo de fratura na qual a tensão diminui de maneira não linear com o aumento da deformação (softening) até ocorrência da fratura completa. Esta zona é cercada por (no limite da superfície elíptica) uma zona de endurecimento onde a tensão aumenta de forma não linear ou permanece constante com a deformação (non linear hardening). Estas duas zonas constituem a zona não linear. (BAZANT, et .al. 1998).
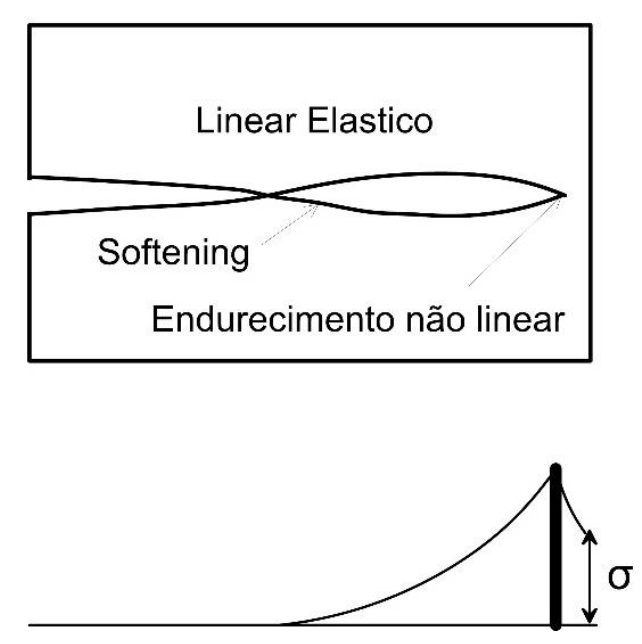

Figura 2.13 - Representação esquemática da distribuição de tensão ao longo da fissura em um material típico quase frágil. (BAZANT, et.al., 1998).

Em materiais quase frágeis, a zona de endurecimento é muitas vezes muito pequena, mas a zona de processo de fratura é grande devido ao dano associado à microfissuração.

Várias abordagens têm sido usadas para modelar o acúmulo de dano em materiais refratários. (GASSER et al., 2001) simulou fissuras em refratários usando um modelo smeared-crack para condições de tração para modelar o comportamento 
de softening. Seus resultados indicaram que o primeiro ciclo térmico causa danos significativos aos revestimentos refratários.

Abordagens baseadas em mecânica de danos contínuos foram utilizadas por vários pesquisadores para modelar danos (DAMHOF; BREKELMANS; GEERS, 2008; LIANG et al., 2007a). Nessas abordagens, os danos causados por microfissuras, porosidade, etc. são representados localmente por uma variável de dano variando de 0 (para material não danificado) a 1 (para um material completamente danificado). O valor da variável de dano é expresso em termos de uma quantidade física mensurável; geralmente é a perda de rigidez elástica em relação ao material não danificado.

(LIANG et al., 2007a) empregaram uma abordagem de danos contínuos para modelar a falha associada a um forro de gaseificador de licor de forma cilíndrica. Consideraram os efeitos térmicos cíclicos, bem como os efeitos da reação química entre a massa fundida e o revestimento refratário. A deformação dependente do tempo e temperatura induzida pela reação química foi incluída como uma deformação inelástica na formulação de elementos finitos no programa ABAQUS. O modelo considerado consistiu em uma faixa 2-D radial de diferentes camadas de tijolos refratários e uma casca de aço no contorno externo. Foi aplicada uma condição de temperatura constante $\left(950^{\circ} \mathrm{C}\right)$ na superfície interna do revestimento e foi assumido que a superfície externa perde calor para o meio ambiente por convecção natural e radiação. A casca exterior de aço foi restringida na direção radial.

O dano previsto pelo modelo para condições que representam 3 meses de operação mostrou que os maiores valores de dano obtidos foram 0,39 e 0,014 em compressão e tração, respectivamente. O maior valor do dano devido à tração ocorreu perto das extremidades. Na face quente do revestimento também se observou um alto valor de dano que indica rachaduras. Embora, os parâmetros de dano previstos não tenham sido validados em relação a dados experimentais, esse modelo fornece um entendimento geral sobre as possíveis localizações das fissuras.

(DAMHOF; BREKELMANS; GEERS, 2008) desenvolveram um modelo de elementos finitos baseado na mecânica de danos contínuos que foi capaz de incorporar as tensões térmicas. Eles incorporaram tensões associadas com o gradiente térmico, bem como as tensões devido às restrições mecânicas externas sobre o refratário. Foi considerado um caso em que uma extremidade de uma barra 
refratária inicialmente a $20^{\circ} \mathrm{C}$ é imersa no alumínio fundido a $1000^{\circ} \mathrm{C}$. A Figura 2.13 mostra o domínio de cálculo com as condições de contorno e a evolução do dano previsto após 10 segundos de aquecimento. A Figura 2.13 (b) mostra o gráfico de contorno da variável de dano. Mostra que o valor máximo do parâmetro de danos, $\sim 0.4$, ocorre perto da extremidade aquecida na superfície. O valor do parâmetro de danos indica uma perda de rigidez de $40 \%$ comparada ao material não danificado. Esta região indica fissuras após 10s de aquecimento.

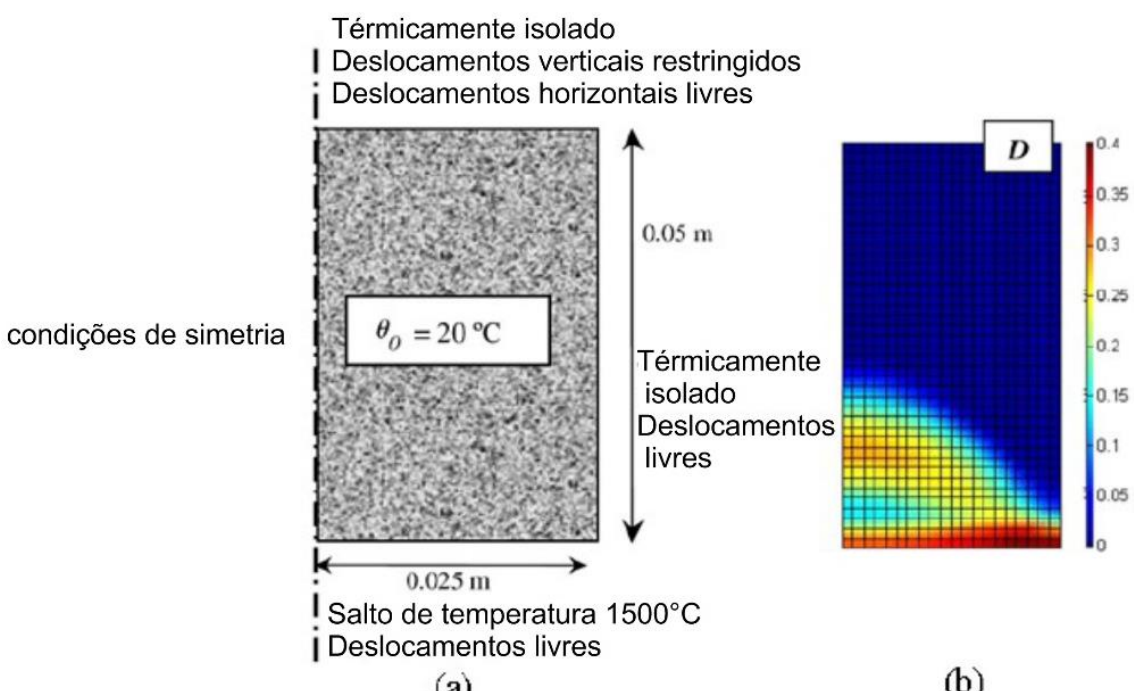

(a)

(b)

Figura 2.14 - (a) Domínio de computação e condições de contorno usadas para a análise de danos e (b) Contorno de dano após 10s de aquecimento.

Em (DAMHOF; BREKELMANS; GEERS, 2011) foi desenvolvida uma simulação de dano ao choque térmico no revestimento refratário de instalações siderúrgica usando um modelo de elementos finitos. Foi considerado um comportamento de danos validada experimentalmente. Os parâmetros que figuram na lei de evolução dos danos baseados na elasticidade dependem da temperatura. Os danos causados pela expansão térmica foram quantificados ao propor uma nova lei constitutiva de evolução. Eles concluíram que tanto o dano de elasticidade induzido por gradientes de temperatura como os danos térmicos induzidos por um aumento uniforme da temperatura contribuem para o dano total. Uma única variável para o dano total é obtida combinando ambos os mecanismos de danos. 
A pesquisa de (HENNEBERG et al., 2013) incorpora a mecânica da fratura na abordagem da mecânica de danos contínuos no mesmo modelo de (DAMHOF; BREKELMANS; GEERS, 2008). Este trabalho fornece uma metodologia para incorporar os fenômenos de iniciação e propagação de microfissuras no modelo de danos. Eles simularam o aquecimento pulsado de uma amostra refratária usando um modelo de elementos finitos. A simulação forneceu informações úteis sobre o comportamento de fissuração do refratário e indicou que o aquecimento de longa duração causa que os efeitos de dano penetrem mais no material e que também causa um dano geral maior em comparação com um aquecimento de duração mais curta.

\subsection{3.}

\section{Fundamentos do modelo constitutivo de plasticidade e dano}

O Modelo de Dano Plástico ou em inglês conhecido como Concrete Damage Plasticity (CDP) é um modelo baseado na plasticidade e dano do material utilizado para modelar o comportamento não linear do concreto e outros materiais quase frágeis. Ele descreve o comportamento constitutivo do concreto, introduzindo parâmetros de dano (de 0 a 1 ). As respostas do comportamento à tração e à compressão do concreto podem ser caracterizadas por CDP como mostra a Figura 2.15. O modelo CDP é baseado nas formulações de Lubliner et.al. (1989) e Lee e Fenves (1998).

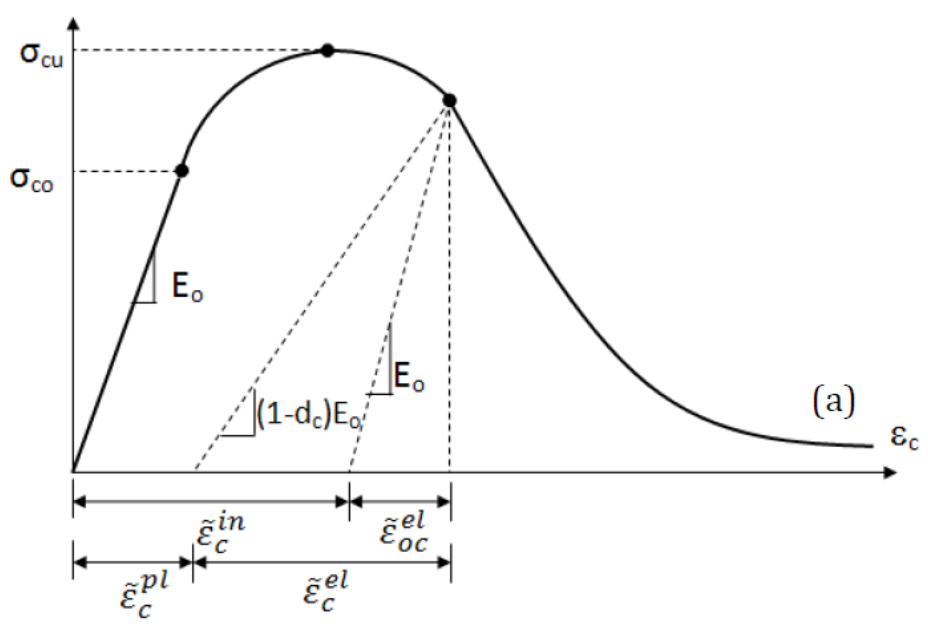




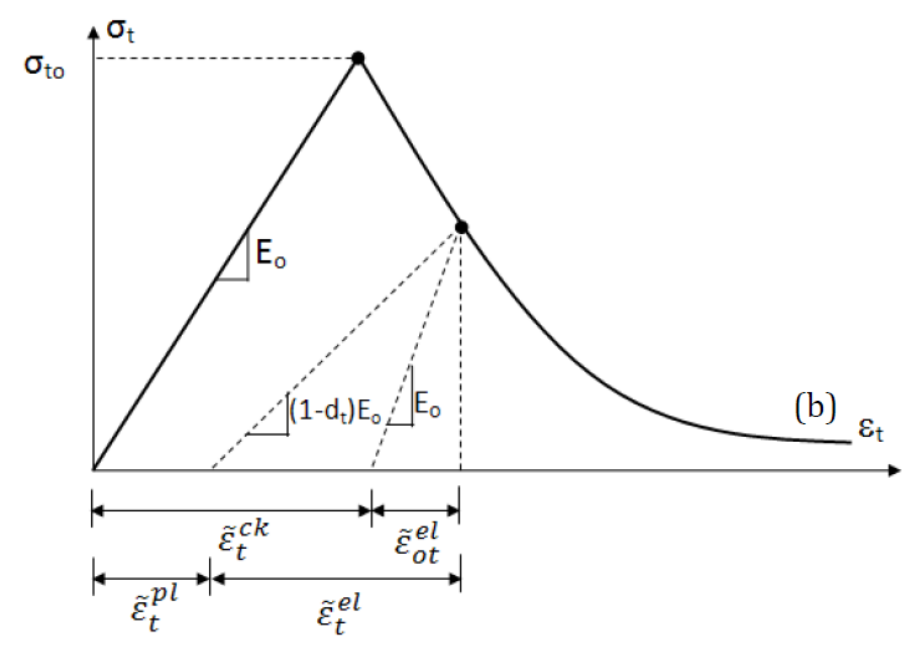

Figura 2.15 - Comportamento do concreto sob a) compressão uniaxial b) tração (ABAQUS USER MANUAL, 2008).

Conforme mostrado na Figura 2.14, a curva no trecho de descarregamento do concreto descreve a perda de rigidez elástica do material por estar danificado ou degradado. A degradação da rigidez elástica na parte de strain-softening da curva tensão-deformação é caracterizada por duas variáveis de dano, $\mathrm{d}_{\mathrm{t}}$ e $\mathrm{d}_{\mathrm{c}}$, que podem ter valores de 0 a 1.0 representa o material não danificado e 1 representa a perda total de resistência (ABAQUS USER MANUAL,2008). $\mathrm{E}_{0}$ é a rigidez elástica inicial (não danificada) do material e $\varepsilon_{c} \sim p l, \varepsilon_{t}^{\sim} \sim p l, \varepsilon_{c} \sim$ in,$\varepsilon_{t}^{\sim \text { in }}$ são a deformação de compressão plástica, deformação de tração plástica, deformação de compressão inelástica e deformação de tração inelástica, respectivamente. As relações tensãodeformação sob tração e compressão uniaxial são dadas pelas Eq. (1) e Eq. (2).

$$
\begin{aligned}
& \sigma_{t}=\left(1-d_{t}\right) \cdot E_{0} \cdot\left(\varepsilon_{t}-\varepsilon_{t}^{\sim p l}\right) \\
& \sigma_{c}=\left(1-d_{c}\right) \cdot E_{0} \cdot\left(\varepsilon_{c}-\varepsilon_{c}^{\sim p l}\right)
\end{aligned}
$$

As tensões de coesão efetivas determinam o tamanho da superfície de escoamento ou superfície de falha. A Figura 2.16 observa-se o ponto em que o concreto falha sob compressão uniaxial. Tem-se a relação $\sigma_{\mathrm{b} 0} / \sigma_{\mathrm{c} 0}$ entre a resistência no estado de tensão biaxial e a resistência no estado de tensão uniaxial. Os parâmetros necessários para definir a superfície de falha consistem em quatro parâmetros constitutivos, o ângulo de dilatação $(\psi)$, excentricidade (e), relação 
$\sigma_{\mathrm{b} 0} / \sigma_{\mathrm{c} 0}$ e parâmetro $\mathrm{K}_{\mathrm{c}}$ que representa a razão entre a distância do eixo hidrostático ao meridiano de tração e de compressão, com valor padrão de $2 / 3$. Uma vez que o valor da tensão crítica é alcançado, o concreto exibe um aumento no volume plástico sob pressão (CHEN, 1982). Este comportamento é levado em consideração definindo um parâmetro chamado ângulo de dilatação. No modelo CDP $\psi$ é o ângulo de dilatação medido no plano com alta pressão de confinamento, fisicamente sendo interpretado como o ângulo de atrito interno do concreto. Em simulações numéricas normalmente adotados entre $36^{\circ}$ e $40^{\circ}$, atreves de analises de sensibilidades de resultados. A excentricidade (e) da superfície potencial plástica com valor padrão de 0.1. A relação entre a tensão de escoamento de compressão biaxial e uniaxial, $\sigma_{\mathrm{b} 0} / \sigma_{\mathrm{c} 0}$, com valor padrão de 1.16 . Uma vez feita a determinação desses parâmetros, o comportamento à compressão e o comportamento à tração são implementados (input) e aplicados nos modelos considerando vários pontos das respectivas curvas tensão-deformação.

O coeficiente de Poisson controla as mudanças de volume de concreto para tensões abaixo do valor crítico, que é o início do comportamento inelástico.

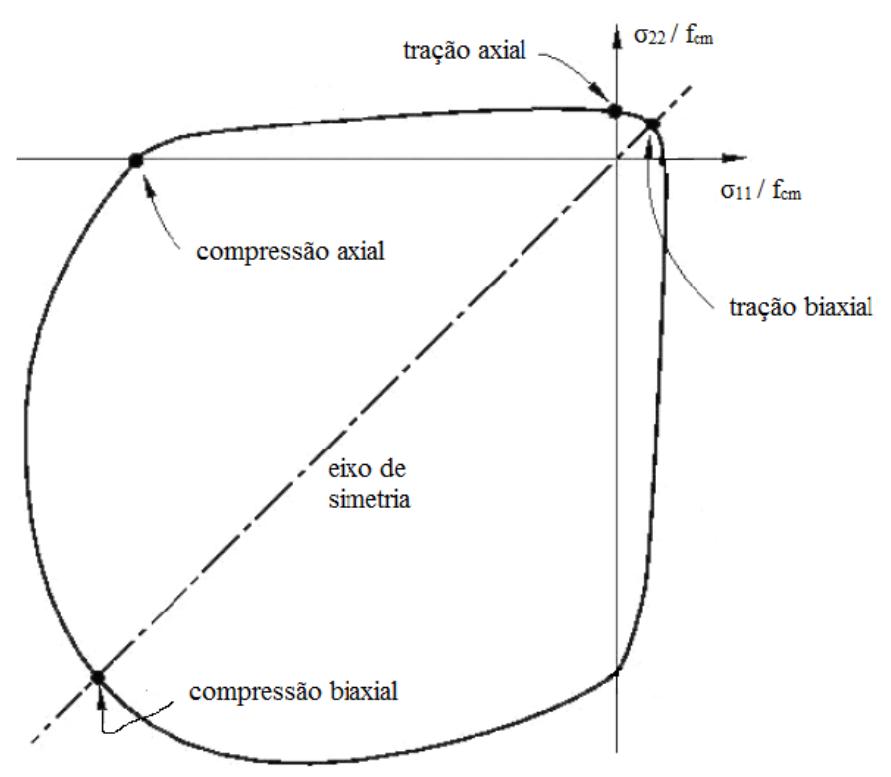

Figura 2.16 - Superfície de produção biaxial no modelo CDP (ABAQUS USER MANUAL, 2008). 


\section{3 Metodologia e resultados}

Este capítulo 3 que inclui as metodologias e análises dos resultados foi dividido em 3 seções. A seção 3.1 apresenta os resultados do comportamento químico e mecânico das matrizes refratárias estudadas na presente pesquisa. Os diferentes concretos refratários foram produzidos com teores de alumina de 51, 71 e $90 \%$ em massa. Estes concretos refratários aluminosos foram primeiramente caracterizados em relação ao comportamento mecânico, análises químicas e microestruturais entre as temperaturas de 25 e $1200^{\circ} \mathrm{C}$. A influência do teor de alumina nas mudanças micro-estruturais e a relação com o comportamento mecânico dos concretos refratários expostos a diferentes temperaturas foi analisada. Esta pesquisa originou o primeiro artigo científico da tese, Artigo A (ver Anexos).

Na seção 3.2 foi desenvolvida a simulação numérica do comportamento termomecânico dos diferentes concretos refratários com base de alumina caracterizados na seção 3.1 em aplicações de revestimentos em multicamadas. Com base nessas análises, foi produzido o Artigo B (ver Anexos). Este artigo apresenta a simulação de diferentes combinações de camadas de revestimento usando os concretos refratários em uma estrutura cilíndrica de aço em condições de uso.

Na seção 3.3 apresenta-se o desenvolvimento de compósitos refratários em diferentes temperaturas. Foi estudado o efeito da adição de fibras de aço inoxidável de formas distintas como reforço da matriz refratária para diferentes temperaturas. Nesta seção também foram validados os modelos numéricos do material compósito correlacionado com os ensaios experimentais estruturais. A partir deste programa 
experimental e numérico foi produzido mais um artigo do estudo, Artigo C (ver Anexos).

\section{1. Comportamento químico e mecânico dos concretos refratários de alumina em diferentes temperaturas (Artigo A).}

A influência de diferentes temperaturas no comportamento químico e mecânico de três tipos de concretos refratários é estudada. Estes materiais foram formulados usando cimentos e agregados de alumina de diferentes qualidades. Os teores de alumina considerados são de 51, 71 e $90 \%$ em massa. A metodologia implementada incluiu: difração de raios X (DRX), análise termogravimétrica (TG/DTG), calorimetria digital de varredura (DSC), fluorescência de raios X (FRX) e testes de compressão uniaxial residual. Após 7 dias de cura no ar a temperatura controlada de $25^{\circ} \mathrm{C}$, os espécimes refratários foram expostos à temperatura ambiente, $150,300,600,1000$ e $1200^{\circ} \mathrm{C}$ e logo ensaiados. O tempo curto de cura de 7 dias é característico dos concretos refratários, nesse tempo atingem 90\% da resistência mecânica e $80 \%$ do módulo de elasticidade em relação aos $100 \%$ dos valores alcançados em 28 dias. A análise comparativa das curvas de tensãodeformação mostrou um comportamento quase-frágil, isto é, linear no início e depois não linear até a fratura para temperaturas entre 25 e $300^{\circ} \mathrm{C}$ e um comportamento viscoplástico para temperaturas elevadas $\left(1000-1200^{\circ} \mathrm{C}\right)$. Os concretos apresentaram diferenças no comportamento mecânico e nas propriedades em função do teor de $\mathrm{Al}_{2} \mathrm{O}_{3}$ e $\mathrm{CaO}$. Para todos os concretos refratários estudados, observou-se uma queda de resistência mecânica com o aumento da temperatura e a $1200^{\circ} \mathrm{C}$ foi observada recuperação na resistência mecânica, associado ao processo 
de ligações cerâmicas. O refratário com $51 \%$ em massa de alumina apresentou um melhor comportamento mecânico em todas as faixas de temperatura consideradas, quando comparado com os demais concretos refratários de $71 \%$ e $90 \%$ de alumina. Os espécimes com $90 \%$ em massa de alumina apresentaram o comportamento mecânico menos degradado (estável) com o aumento da temperatura. Os resultados indicam que esses concretos refratários aluminosos com diferentes propriedades mecânicas podem ser usados em combinação como material de revestimento em altas temperaturas e aplicados em camadas.

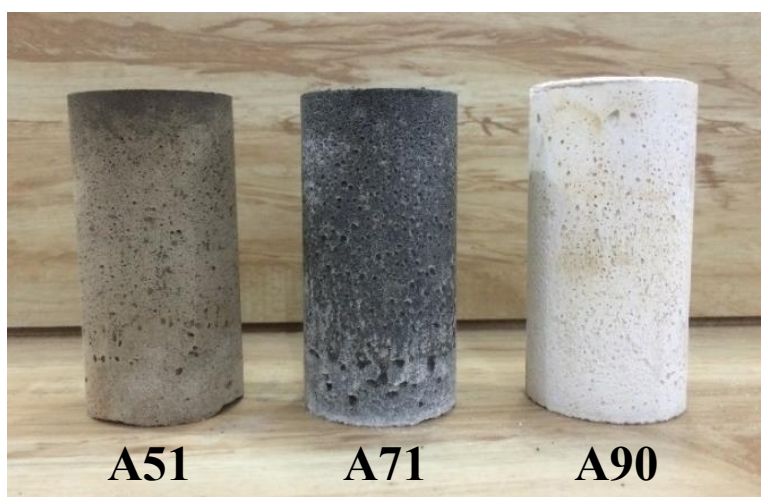

Figura 3.1 - Corpos de provas dos diferentes concretos refratários a base de cimento aluminoso.

\section{2. \\ Simulação do comportamento termomecânico de concretos refratários aplicados em revestimentos (Artigo B).}

Concretos refratários são amplamente aplicados para o revestimento de estruturas de aço submetidas a altas temperaturas e pressões. Revestimentos de unidades de produção industriais de aço são feitos de concretos de alta alumina, isto é, utilizados nas primeiras camadas que recebem o fluxo de calor. A modelagem do comportamento termomecânico dessas camadas sob condições de serviço é de suma 
importância para avaliar o surgimento de fissuras e/ou falhas que determinam a vida útil desses materiais. Neste trabalho foram realizadas simulações do processo de aquecimento e carregamento em revestimentos compostos de diversas camadas de diferentes tipos de refratários com diferentes teores de alumina (51, 71 e 90\% em peso), previamente estudados (item 3.1). O modelo de elementos finitos axissimétricos desenvolvido e as análises termomecânicas foram realizadas utilizando o pacote de software ABAQUS. As análises consideraram o fluxo de calor transitório e estacionário para validação analítica do modelo. As simulações do processo de aquecimento foram realizadas para diferentes combinações de posicionamento das camadas feitas dos diferentes concretos refratários. Os resultados da resposta termomecânica foram comparados e observou-se que a combinação que usou o concreto refratário com $90 \%$ de alumina como camada interna, combinada com os concretos refratários de $71 \%$ e $51 \%$ como as camadas média e externa, respectivamente, resultou em uma solução mais eficiente em termos do gradiente térmico. Portanto, potencialmente levaria a menores danos ao revestimento durante todo o processo de operação. Isto indica a importância da seleção dos materiais de revestimento para aplicação em camadas. Além disso, as simulações mostraram que essa combinação de camadas de revestimento | A90 | A71 | A90 | apresentou menores áreas propensas a fissuração.

\section{3. \\ Comportamento termomecânico dos compósitos refratários reforçados com fibras de aço inoxidável (Artigo C).}

O reforço de concretos refratários com fibras de aço inoxidável pode melhorar sensivelmente o comportamento termomecânico dos compósitos. Os efeitos das 
fibras dependem do material, da forma, da interface e da fração de volume das fibras. Além disso, as temperaturas de queima influenciam no comportamento termomecânico do concreto refratário reforçado. O objetivo é estudar o comportamento termomecânico do concreto refratário à base de alumina reforçado com fibra de aço inoxidável de diferentes formatos. Utilizou-se fibra de aço inoxidável de forma reta, ondulada e recartilhada. Um programa de pesquisa de ensaios experimentais e simulações numéricas foi realizado. Ensaios de flexão de três pontos (incluindo ensaios cíclicos), arrancamento de fibras, tração direta e compressão foram executados para corpos de prova expostos em temperatura entre 25 e $1000^{\circ} \mathrm{C}$. Obteve-se a caracterização residual dos compósitos refratários para determinação das relações constitutivas do modelo do material. O modelo Concrete Damage Plasticity implementado no software ABAQUS permitiu realizar simulações numéricas de ensaios estruturais de painéis circulares reforçados com as fibras em diferentes temperaturas. Foi feita a validação dos métodos numéricos com os métodos experimentais por meio da correlação das curvas de resultados. Simulações dos ensaios de flexão de três pontos também foram feitas para entender a evolução do dano do compósito refratário com a temperatura. Nestes testes, a análise de correlação digital de imagem (DIC) foi acoplada para obter campos de deformação em diferentes etapas do ensaio. Os resultados de flexão mostraram melhor comportamento para o reforço com fibra recartilhada para todas as temperaturas devido a melhores características de aderência com a matriz refratária. Os ensaios experimentais e as simulações numéricas mostraram que o reforço beneficia o comportamento mecânico pré-pico e pós-pico dos compósitos refratários. A influência observada nas curvas de abrandamento (softening) indicam a importância para os projetos estruturais. 


\section{4 \\ Conclusões e sugestões para trabalhos futuros}

O estudo experimental do comportamento de compósitos refratários reforçados com fibras de aço inoxidável em diferentes temperaturas foi desenvolvido por meio de análises microestruturais e de diferentes ensaios mecânicos residuais. Foram caracterizados primeiro diferentes tipos de concretos refratários a base alumina com teor de 51,71 e $90 \%$ em peso para a matriz do compósito. Logo, o comportamento termomecânico desses diferentes concretos refratários aluminosos caracterizados foi avaliado em serviço para uma aplicação de revestimento em camadas (lining) em escala componente usando o método de elementos finitos.

O concreto refratário com $51 \%$ de alumina foi selecionado para o desenvolvimento do programa experimental e numérico dos compósitos refratários reforçados com diferentes fibras de aço inoxidável em diferentes temperaturas. Os estudos realizados permitiram obter resultados que levaram as seguintes conclusões:

A influência do teor de alumina na matriz refratária revelou que os concretos com $51 \%$ de alumina apresentaram um comportamento mecânico com maiores valores de resistência mecânica e módulo de elasticidade, em relação aos concretos com $71 \%$ e $90 \%$ no intervalo de temperatura de $25-1200^{\circ} \mathrm{C}$. No entanto, o concreto refratário com $90 \%$ de alumina mostrou-se mais estável em relação a mudanças nas propriedades mecânicas com o aumento da temperatura. 
A modelagem numérica evidenciou a eficiência do uso do concreto refratário com $90 \%$ de alumina como camada interna combinado com os concretos de $71 \%, 51 \%$ como camada do meio e camada externa, respectivamente. Isto, associado a maior refratariedade que beneficia o gradiente térmico gerado no revestimento durante o processo de aquecimento e uso.

Os reforços de fibras de aço inoxidável melhoraram significativamente o comportamento termomecânico do concreto refratário. A fibra recartilhada apresentou maior ganho de resistência e tenacidade nas diferentes temperaturas analisadas, em comparação as fibras onduladas e retas. Este efeito mais notório deve-se em maior parte ao tratamento de recartilhado da superfície da fibra, o que aumenta a aderência entre fibra e matriz refratária.

A simulação numérica do comportamento não linear do concreto refratário em diferentes temperaturas foi considerado utilizando o modelo concrete damage plasticity. Este modelo apresentou uma boa correlação com os ensaios experimentais. A validação do modelo permite realizar simulações numéricas em painéis circulares em diferentes temperaturas.

Dentro das sugestões de trabalhos futuros, a metodologia experimental aplicada ao compósito refratário pode ser aplicada para as demais matrizes de concretos refratários estudadas nesta pesquisa. Resultados dos ensaios à quente (in situ) podem ser comparados com os obtidos nos ensaios residuais. 
A modelagem numérica do sistema de revestimento incorporando a simulação do comportamento termomecânico não linear do compósito para temperaturas acima de $1200^{\circ} \mathrm{C}$ pode ser realizado futuramente. Isso seria especialmente interessante para aplicações estruturais, como por exemplo o ensaio do painel circular, uma vez que osfornos das dimensões necessárias para realizar estes ensaios e que atinjam altas temperaturas são limitados 


\section{5 \\ Referências Bibliográficas}

ABAQUS USER'S MANUAL. Abaqus User's Manual. version 6.12, p. 1174, 2012.

AKIYOSHI, M. M. et al. A influência simultânea do teor de alumina, da porosidade total e da temperatura na condutividade térmica de refratários sílicoaluminosos e aluminosos. Cerâmica, v. 47, n. 303, p. 163-169, 2001.

AMRANE, B. et al. Experimental study of the thermo-mechanical behaviour of alumina-silicate refractory materials based on a mixture of Algerian kaolinitic clays. Ceramics International, v. 37, n. 8, p. 3217-3227, 2011.

ANDREEV, K.; HARMUTH, H. FEM simulation of the thermo-mechanical behaviour and failure of refractories - A case study. Journal of Materials Processing Technology, v. 143-144, n. 1, p. 72-77, 2003.

AUVRAY, J. M.; GAULT, C.; HUGER, M. Evolution of elastic properties and microstructural changes versus temperature in bonding phases of alumina and alumina-magnesia refractory castables. Journal of the European Ceramic Society, v. 27, n. 12, p. 3489-3496, 2007.

AUVRAY, J. M.; GAULT, C.; HUGER, M. Microstructural changes and evolutions of elastic properties versus temperature of alumina and aluminamagnesia refractory castables. Journal of the European Ceramic Society, v. 28, n. 10, p. 1953-1960, 2008.

BAREIRO, W. G. et al. The influence of alumina content on the chemical and mechanical behavior of refractory concretes fired at different temperatures. International Journal of Applied Ceramic Technology, 2018.

BAZANT, Z. P., KAPLAN, M. F., 1996, Concrete at High Temperatures.

BENALI, F. et al. Thermo-mechanical characterization of a silica-alumina refractory concrete based on calcined algerian kaolin. Ceramics International, v. 42, n. 8, p. 9703-9711, 2016.

C. PARR, F. SIMONIN, B. TOUZO, C.WÖHRMEYER, B. VALDELIÈVRE, A. N. The impact of calcium aluminate cement hydration upon 
the properties of refractory castables. TARJ meeting, v. 33, n. September, p. 1-17, 2004.

C. WÖHRMEYER, C. PARR, H. FRYDA, E. F. Aggregates for non-ferrous Applications. The Refractories World Forum, Edition 2/2011, n. March, p. 1$12,2012$.

CARVAlHO, M. C. DE et al. Computational Simulation of Ladles of. Tecnologia em Metalurgia, Materiais e Mineração, v. 11, p. 138-145, 2014.

CHEN, Y. T. AND J. F. Concrete Damage Plasticity Model for Modeling. M.ASCE, v. 19, n. 1, p. 1-13, 2015.

CICEKLI, U.; VOYIADJIS, G. Z.; ABU AL-RUB, R. K. A plasticity and anisotropic damage model for plain concrete. International Journal of Plasticity, v. 23, n. 10-11, p. 1874-1900, 2007.

DAMHOF, F.; BREKELMANS, W. A. M.; GEERS, M. G. D. Non-local modeling of thermal shock damage in refractory materials. Engineering Fracture Mechanics, v. 75, n. 16, p. 4706-4720, 2008.

DAMHOF, F.; BREKELMANS, W. A. M.; GEERS, M. G. D. Predictive FEM simulation of thermal shock damage in the refractory lining of steelmaking installations. Journal of Materials Processing Technology, v. 211, n. 12, p. 20912105, 2011.

DÍAZ, L. A. et al. Room temperature mechanical properties of high alumina refractory castables with spinel, periclase and dolomite additions. Journal of the European Ceramic Society, v. 28, n. 15, p. 2853-2858, 2008.

DONVAL, N. et al. Comportement mecanique de betons refractaires fibres. 2011.

GRASSL, P.; JIRÁSEK, M. Damage-plastic model for concrete failure. International Journal of Solids and Structures, v. 43, n. 22-23, p. 7166-7196, 2006.

GRUBER, D.; ANDREEV, K.; HARMUTH, H. FEM simulation of the thermomechanical behaviour of the refractory lining of a blast furnace. Journal of Materials Processing Technology, v. 155-156, n. 1-3, p. 1539-1543, 2004.

GUPTA, S. K. Refractories for iron making,. Industrial Minerals, p. 29-35, 2017.

H. SARPOOLAKY, K.G. AHARI, W. E. L. Influence of in situ phase formation on properties of calcium zirconate refractories. Journal of the European 
Ceramic Society, v. 37, n. 1, p. 487-493, 2002.

HILLERBORG, A.; MODEER, M; PETERSON, P.-E. Analysis of crack formation and crack growth in concrete by means of fracture me-chanics and finite elements. Cement and Concrete Research, v. 6, p. 773-782, 1976.

J. HARVEY, S. B. Important factors in the selection of steel ladle lining materials. Tehran International Conference on Refractories, n. May, p. 4-6, 2004.

KAKROUDI, M. et al. Damage evaluation of two alumina refractory castables. Journal of the European Ceramic Society, v. 29, n. 11, p. 2211-2218, 2009.

KAKROUDI, M. G. et al. Effect of thermal treatment on damage mechanical behaviour of refractory castables: Comparison between bauxite and andalusite aggregates. Journal of the European Ceramic Society, v. 28, n. 13, p. 2471-2478, 2008 .

KATSAVOU, I. D.; KROKIDA, M. K.; ZIOMAS, I. C. Determination of mechanical properties and thermal treatment behavior of alumina-based refractories. Ceramics International, v. 38, n. 7, p. 5747-5756, 2012.

KMIECIK, P.; KAMIĒSKI, M. Modelling of reinforced concrete structures and composite structures with concrete strength degradation taken into consideration. v. XI, n. 3, 2011.

LI, G. et al. Influence of working lining parameters on temperature and stress field of ladle. Applied Mathematics and Information Sciences, v. 7, n. 2, p. 439448, 2013.

LIANG, $\mathrm{X}$. et al. Modeling of failure in a high temperature black liquor gasifier refractory lining. Engineering Failure Analysis, v. 14, n. 7, p. 1233-1244, 2007a.

LIANG, $\mathrm{X}$. et al. Modeling of failure in a high temperature black liquor gasifier refractory lining. Engineering Failure Analysis, v. 14, n. 7, p. 1233-1244, $2007 b$.

LOURENÇO, R. R. et al. Sonochemical action and the influence of heat treatment conditions on the preparation of cements of the $\mathrm{CaO}-\mathrm{A} 12 \mathrm{O} 3$ binary system. Cerâmica, v. 56, n. 337, p. 28-38, 2010.

MARZAGUI, H. Étude de deux bétons réfractaires silico-alumineux: microstructure et comportement thermomécaniques en traction et en flexion 
Consulter en bibliothèque La version de soutenance existe sous forme papier. (Thèse de doctorat), Université Toulouse, France, 2005.

MARZAGUI, H.; CUTARD, T. Characterisation of microstructural evolutions in refractory castables by in situ high temperature ESEM. Journal of Materials Processing Technology, v. 155-156, n. 1-3, p. 1474-1481, 2004.

MAZZONI, A.; BERNHART, G.; CUTARD, T. Ceramic fibre reinforced refractory castables for very high temperature superplastic forming. Materialwissenschaft und Werkstofftechnik, v. 43, n. 9, p. 758-762, 2012.

MEDDAH, A.; BELAGRAA, L.; BEDDAR, M. Effect of the fibre geometry on the flexural properties of reinforced steel fibre refractory concrete. Procedia Engineering, v. 108, p. 185-192, 2015.

MUÑOZ, V.; MARTINEZ, A. G. T. Factors controlling the mechanical behavior of alumina-magnesia-carbon refractories in air. Ceramics International, v. 42, n. 9, p. 11150-11160, 2016.

MUÑOZ, V.; PENA, P.; MARTÍNEZ, A. G. T. Physical, chemical and thermal characterization of alumina-magnesia-carbon refractories. Ceramics International, v. 40, n. 7 PART A, p. 9133-9149, 2014.

MUNOZ, V.; TOMBA MARTINEZ, A. G. Thermal Evolution of Al2O3MgO-C Refractories. Procedia Materials Science, v. 1, p. 410-417, 2012.

MUÑOZ, V.; TOMBA MARTINEZ, A. G. Thermomechanical behaviour of $\mathrm{Al} 2 \mathrm{O} 3-\mathrm{MgO}-\mathrm{C}$ refractories under non-oxidizing atmosphere. Ceramics International, v. 41, n. 3, p. 3438-3448, 2015.

NIKIFOROV, A. S.; PRIKHOD'KO, E. V. Thermal stresses generated in the lining of a steel ladle. Refractories and Industrial Ceramics, v. 46, n. 5, p. 360 $363,2005$.

NONNET, E.; LEQUEUX, N.; BOCH, P. Elastic properties of high alumina cement castables from room temperature to $1600^{\circ} \mathrm{C}$. Journal of the European Ceramic Society, v. 19, n. 8, p. 1575-1583, 1999.

NOURI-KHEZRABAD, $M$. et al. Developing nano-bonded refractory castables with enhanced green mechanical properties. Ceramics International, v. 41, n. 2, p. 3051-3057, 2015.

OBRADOVIC, N. et al. Dehydration investigations of a refractory concrete using DTA method. Journal of Thermal Analysis and Calorimetry, v. 110, n. 1, p. 37-41, 2012. 
OUEDRAOGO, E. et al. Refractory concretes uniaxial compression behaviour under high temperature testing conditions. Journal of the European Ceramic Society, v. 31, n. 15, p. 2763-2774, 2011.

OUEDRAOGO, E.; PROMPT, N. High-temperature mechanical characterisation of an alumina refractory concrete for Blast Furnace main trough PART II . Material behaviour. v. 28, p. 2867-2875, 2008.

PANDHARI, A. Modeling of Thermal Stress Cycling in Refractory Materials. n. July, 2017.

PEREIRA, R. et al. Avaliação de taxas de aquecimento em materiais refratários: comparação entre simulações físicas e cálculos computacionais. Cerâmica, v. 48, n. 306, 2002.

POLLMANN, H. Calcium aluminate cements - raw materials, differences, hydration and properties. Reviews in Mineralogy and Geochemistry, v. 74, n. 1, p. 1-82, 2012.

PROMPT, N.; OUEDRAOGO, E. High temperature mechanical characterisation of an alumina refractory concrete for Blast Furnace main trough. Part I. General context. Journal of the European Ceramic Society, v. 28, n. 15, p. 2859-2865, 2008.

RAMBO, D. A. S. et al. Effect of elevated temperatures on the mechanical behavior of basalt textile reinforced refractory concrete. Materials and Design, v. 65, p. 24-33, 2015.

RAMBO, D. A. S. et al. Experimental investigation and modelling of the temperature effects on the tensile behavior of textile reinforced refractory concretes. Cement and Concrete Composites, v. 75, p. 51-61, 2017.

RAMBO, D. A. S.; SILVA, F. DE A.; TOLEDO FILHO, R. D. Mechanical behavior of hybrid steel-fiber self-consolidating concrete: Materials and structural aspects. Materials and Design, v. 54, p. 32-42, 2014.

RIBEIRO, S.; RODRIGUES, J. A. The influence of microstructure on the maximum load and fracture energy of refractory castables. Ceramics International, v. 36, n. 1, p. 263-274, 2010.

SCHMITT, N. et al. Coupling between kinetics of dehydration, physical and mechanical behaviour for high alumina castable. Cement and Concrete Research, v. 30, n. 10, p. 1597-1607, 2000.

SIMONIN, F. et al. Thermomechanical Behavior of High-Alumina 
Refractory Castables with Synthetic Spinel Additions. J. Am. Ceram. Soc., v. 83, n. 188961, p. 2481-2490, 2000.

SIMONIN, F. Comportement thermomécanique de bétons réfractaires alumineux contenant du spinelle de magnésium. 2000.

SIMONIN, F. et al. Room temperature quasi-brittle behaviour of an aluminous refractory concrete after firing. Journal of the European Ceramic Society, v. 22, n. 2, p. 165-172, 2002.

SOUKAL, F. et al. High temperature properties of MDF composite based on calcium aluminate cement and polyvinyl alcohol. Journal of Thermal Analysis and Calorimetry, v. 115, n. 2, p. 1245-1252, 2014.

SOUZA, T. M. et al. In situ elastic modulus evaluation of $\mathrm{Al} 2 \mathrm{O} 3-\mathrm{MgO}$ refractory castables. Ceramics International, v. 40, n. 1 PART B, p. 1699-1707, 2014.

STRAUSS RAMBO, D. A. et al. Tensile strength of a calcium-aluminate cementitious composite reinforced with basalt textile in a high-temperature environment. Cement and Concrete Composites, v. 70, p. 183-193, $2016 \mathrm{a}$.

STRAUSS RAMBO, D. A. et al. Exposing Calcium aluminate mortar to high temperatures: Overcoming adverse conversion effects using clinker aggregates. Cement and Concrete Research, $2016 b$.

STRESSES, T. et al. Thermal stresses generated in the linning of a steel ladle. v. 46 , n. 5 , p. 360-363, 2005.

SÜMER, Y.; AKTAŞ, M. Defining parameters for concrete damage plasticity model. Challenge Journal of Structural Mechanics, v. 1, n. 3, p. 149-155, 2015.

TERZIĆ, A.; PAVLOVIĆ, L. Correlation among sintering process, porosity, and creep deformation of refractory concrete. Journal of Materials Science, v. 44, n. 11, p. 2844-2850, 2009.

TOUZO, B. et al. Microstructural Changes in Calcium Aluminates Cement Bonded Castable Systems. Technical Paper (Unitecr 2005), v. 33, n. 0, p. 1-10, 2005 .

TSIBIN, I. P.; KUZNETSOV, A. T. A physical model of thermal failure of refractory concretes. Refractories, v. 29, n. 1-2, p. 43-48, 1988.

WÖHRMEYER, C. et al. New Calcuim Aluminate Aggregates for Refractory Castables Installed in Highly Abrasive Environments. 16th Conference on Refractories,Czech Silicate Society, Prague, Czech Republic, p. 1-13, 2011 a. 
WÖHRMEYER, C. et al. Calcium Aluminate Aggregates for use in Refractory Castables. 35th American Ceramic Society Symposium, St. Louis, Missouri, USA, March 1999, v. 33, n. March, p. 1-13, 2011 b.

WORLD STEEL ASSOCIATION. Energy use in the steel industry. World Steel 
Anexos

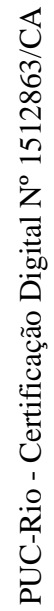




\section{Artigo A The influence of alumina content on the chemical and mechanical behavior of refractory concretes fired at different temperatures}

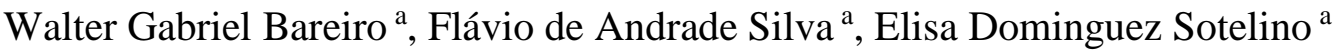
and Otávio da Fonseca Martins Gomes ${ }^{\text {bc }}$

${ }^{a}$ Department of Civil and Environmental Engineering, Pontifícia Universidade Católica do Rio de Janeiro, (PUC-Rio), Rua Marquês de São Vicente 225, 22451900, Gávea, Rio de Janeiro - RJ, Brazil.

b CETEM - Centre for Mineral Technology, Av. Pedro Calmon, 900, Ilha da Cidade Universitária, 21941-908 Rio de Janeiro, Brazil.

${ }^{\mathrm{c}}$ Postgraduate Program in Geosciences, National Museum, Federal University of Rio de Janeiro (UFRJ), Av. Quinta da Boa Vista, S/N, São Cristóvão, Rio de Janeiro 20940-040, Brazil. 


\begin{abstract}
The influence of different temperatures on the chemical and mechanical behavior of three types of refractory concretes is studied. These materials were formulated using cements and alumina aggregates of different qualities. The alumina content considered is 51,71 and $90 \mathrm{wt} . \%$. The methodology implemented included: X-ray diffraction (XRD), thermogravimetric analysis (TGA), digital scanning calorimetry (DSC) and compression tests. After 7 days of curing, specimens were exposed to room temperature, $150,300,600,1000$ and $1200^{\circ} \mathrm{C}$ and tested. The comparative analysis of the stress strain curves showed a quasi-brittle behavior, linear at the beginning and then non-linear until fracture. The concretes exhibited differences in the mechanical behavior and properties in function of the content of $\mathrm{Al}_{2} \mathrm{O}_{3}$ and $\mathrm{CaO}$. For all refractories, a mechanical strength drop was observed as the temperature increased and at $1200^{\circ} \mathrm{C}$ a recovery in the mechanical strength was noticed. The refractory with $51 \mathrm{wt} . \%$ of alumina showed an improved mechanical behavior for all temperature ranges when compared with to the others. The specimens with $90 \mathrm{wt} . \%$ of alumina had the least degraded mechanical behavior with the increase in temperature. The results indicate that different refractories with different mechanical properties can be used together as a lining material and applied in layers.
\end{abstract}

Keyword: refractory concrete, cements and alumina aggregates, thermal loading, mineralogical changes, physico-chemical changes, mechanical properties. 
Cement notation:

$\mathrm{C}=\mathrm{CaO}$

$\mathrm{A}=\mathrm{Al}_{2} \mathrm{O}_{3}$

$\mathrm{F}=\mathrm{Fe}_{2} \mathrm{O}_{3}$

$\mathrm{S}=\mathrm{SiO}_{2}$

$\mathrm{H}=\mathrm{H}_{2} \mathrm{O}$

$\mathrm{T}=\mathrm{TiO}_{2}$

\section{Introduction}

Refractory concretes are mainly used in industrial applications, such as steel structure linings and steelmaking ladles. These materials are exposed to high thermal and mechanical loads during their service life. During the last decades, the evolution of processes in the industry has increasingly demanded a higher performance of refractory products. Therefore, they are of wide technological interest for use as linings applications [1,2].

The most commonly used binder in the preparation of refractory concretes is the calcium aluminate cement (CAC). Concretes based on CAC have a faster setting process than normal Portland cements [3]. Studies on the microstructural evolution of CAC-based concretes with the general mineralogical composition $\left(\mathrm{CA}, \mathrm{CA}_{2}\right.$, $\mathrm{C}_{12} \mathrm{~A}_{7}$, etc) when exposed to high temperatures show the occurrence of dehydration, hydrate conversion, crystallization and sintering [4-6]. These reactions occur in different temperature ranges. Dehydration of the matrix $\left(110-150^{\circ} \mathrm{C}\right)$ includes the evaporation of free water and of the structural water of the $\mathrm{AH}_{\mathrm{x}}$ gel and the loss of metastable hydrates $\mathrm{CAH}_{10}\left(\mathrm{CaO} \cdot \mathrm{Al}_{2} \mathrm{O} 3 \cdot 10 \mathrm{H}_{2} \mathrm{O}\right)$ and $\mathrm{C}_{2} \mathrm{AH}_{8}\left(2 \mathrm{CaO} \cdot \mathrm{Al}_{2} \mathrm{O}_{3} \cdot 8 \mathrm{H}_{2} \mathrm{O}\right)$ among others, but these are the main processes $[7,8]$. The conversion of stable 
hydrates into $\mathrm{AH}_{3}\left(\mathrm{Al}_{2} \mathrm{O}_{3} \cdot 3 \mathrm{H}_{2} \mathrm{O}\right)$ and $\mathrm{C}_{3} \mathrm{AH}_{6}\left(3 \mathrm{CaO} \cdot \mathrm{Al}_{2} \mathrm{O}_{3} \cdot 6 \mathrm{H}_{2} \mathrm{O}\right)$ is accelerated by increasing the temperature. The above mentioned processes occur through the following reactions $[4,7]$ :

$$
\begin{gathered}
3 \mathrm{CAH}_{10} \rightarrow \mathrm{C}_{3} \mathrm{AH}_{6}+2 \mathrm{AH}_{3}+18 \mathrm{H} \\
3 \mathrm{C}_{2} \mathrm{AH}_{8} \rightarrow 2 \mathrm{C}_{3} \mathrm{AH}_{6}+\mathrm{AH}_{3}+9 \mathrm{H}
\end{gathered}
$$

The conversion reactions induce a decrease of the mechanical properties of the concrete [7], which is considered transient for materials with low water/cement ratio. The CAC based matrices are developed for applications subjected to extreme conditions, such as elevated temperature and high operation loading, which are known to have adverse effects, such as the reduction of resistance caused by conversion reactions. However, the distinct behavior of the matrices, in certain cases, result in competitive materials. These types of concrete are able to compensate for the conversion consequences and recover part of the mechanical properties by additional hydration of the anhydride phases of the cement. This was confirmed by Nonnet et al. [4], which showed that the decrease in CA content in the material is accompanied by the increase of the elastic modulus. The transformation to crystallization of the phases indicated in $[4,5]$ at high temperatures (above $1000^{\circ} \mathrm{C}$ ) depends mainly on the composition of the $\mathrm{CAC}$ and the aggregates [7]. Some aggregates used in CAC refractory concretes are fused alumina, chamotte, sintered bauxite and chromite $[9,10]$. At higher temperatures, above $1000^{\circ} \mathrm{C}, \mathrm{CA}_{2}$ and $\mathrm{CA}_{6}$ formation and sintering takes place. $\mathrm{CA}_{2}$ is formed from $\mathrm{CA}$ and $\mathrm{A}$. Then the formation of $\mathrm{CA}_{6}$ from $\mathrm{CA}_{2}$ and $\mathrm{A}$, occurs. The sintering process produces phase changes strengthening the ceramics bonding characteristics. This provokes a new increase in strength $[4,11]$. 
According to the literature $[1,2,4,7,8,12,13]$ the degradation mechanisms affecting the behavior of these concretes is influenced by many factors, such as chemical composition, microstructure and phase transformations during the firing process. It is known that large microstructural changes can occur, which frequently cause microcracking damage, leading to a non-linear behavior when subjected to compression or tensile loading [14]. Research works can be found in the literature related to the damage assessment of refractory concretes from ambient temperature to $1000^{\circ} \mathrm{C}$ using different techniques such as electron microscopy, ultrasonic and mechanical test [15-17]. These studies reported the evolution of mechanical behavior with the increase in firing temperature, showing that at temperatures ranging from 25 to $300^{\circ} \mathrm{C}$ the material exhibited a quasi-brittle behavior. At high temperatures (from 600 to $1200^{\circ} \mathrm{C}$ ) a viscoplastic behavior is observed. In relation to the elastic modulus, a decrease in magnitude is observed at temperatures ranging from 29 to $300^{\circ} \mathrm{C}$ and an increase in magnitude is seen at high temperatures $\left(>1000^{\circ} \mathrm{C}\right)$

Recent works on the thermomechanical behavior of CAC based matrices mixed with synthetic and refractory aggregates have reported a correlation of the microstructural evolutions with mechanical properties $[1,2,7,8]$. Muñoz et al. [1,2] established a methodology for chemical and mineralogical characterization and established the factors controlling the mechanical behavior of alumina-magnesiacarbon refractories. The data obtained for the three different compositions of the refractories showed a similar thermal evolution, with the same transformations occurring between 400 and $1400^{\circ} \mathrm{C}$. The mechanical behavior, however, showed significant differences that were attributed to mineralogical composition. Rambo et al. $[7,8,18]$ studied the effect of high temperatures on the mechanical behavior of 
textile refractory composites using cement with $51 \mathrm{wt} . \%$ alumina. As reported by the authors, the thermal decomposition of the matrix and the loss of tensile strength, starting at $150^{\circ} \mathrm{C}$, were correlated to the process of dehydration of the main products, $\mathrm{CAH}_{10}$ and $\mathrm{C}_{2} \mathrm{AH}_{8}$, and to the decomposition of phases $\mathrm{AH}_{3}$ and $\mathrm{C}_{3} \mathrm{AH}_{6}$ between 200 and $400^{\circ} \mathrm{C}[19,20]$.

The study of the thermomechanical behavior of alumina-silicate concrete exposed up to $1450^{\circ} \mathrm{C}$ performed by Benali et al. [12] showed that the elastic modulus and compressive strength reach the maximum value at temperatures between 700 and $900^{\circ} \mathrm{C}$. Ouedrogo et al. [21,22] investigated the influence of temperatures, up to $1500{ }^{\circ} \mathrm{C}$, on the mechanical behavior of a high alumina concrete (80wt.\%). The study showed that the material presented a quasi-brittle and nonlinear behavior for intermediate temperatures and a viscous behavior at higher temperatures. However, the material exhibited a clear increase in compressive strength up to intermediate temperatures. The thermal evolution of two alumina refractory concretes was analyzed by Kakroudi et al. [23]; one with bauxite and the other with andalusite. The uniaxial tensile tests performed after the concretes were subjected to various temperatures showed significant damage to the elastic modulus of both concretes. Souza et al. [24] determined the elastic modulus of a $\mathrm{Al}_{2} \mathrm{O}_{3}-\mathrm{MgO}$ refractory concrete for temperatures ranging from ambient to $1400^{\circ} \mathrm{C}$. The results showed that the modulus of elasticity decreased $60 \%$ at intermediate temperatures and then increased at elevated temperatures, reaching $80 \%$ of the initial value.

The present paper reports particular combinations of raw materials, which produce concretes showing different behaviors. The results of an experimental investigation on the influence of temperature on the chemical and mechanical behavior of refractory concretes with different levels of alumina (51wt.\%, 71wt.\% 
and $90 \mathrm{wt} . \%$ ) is reported. The mechanical characterization of the three concretes fired to temperatures ranging between 25 and $1200^{\circ} \mathrm{C}$ was carried out through compression tests. The material's mineralogical changes due to the varying temperatures were studied through thermogravimetric analysis (TGA), digital scanning calorimetry (DSC) and X-ray diffraction. The concretes exhibit differences in the mechanical behavior and properties depending on the $\mathrm{Al}_{2} \mathrm{O}_{3}$ and $\mathrm{CaO}$ content and on the particular thermal evolution. These types of concretes could be applied in the design of layered linings to protect steel structures in a high temperature environment. The concept of using layered lining consists of applying the material with the performance that best suits the application of this layer. For example, layers that are subjected directly to the hot surface, need to maintain refractoriness and have less propensity to cracking.

\section{Experimental Procedure}

\subsection{Refractory concrete types and manufacturing methodology}

Three types of refractory concretes were produced in the laboratory. They differ mainly in the alumina content in the cement: $51 \mathrm{wt} . \%, 71 \mathrm{wt} . \%$ and $90 \mathrm{wt} . \%$ and different types of aggregate. These concretes are designated in the present work as A51, A71 and A90, respectively. Commercial materials were used in the composition of these concretes. Three different cements were manufactured by Kerneos (France): Secar 51, Secar 71 and Secar 80. The aggregates compatible with the chemical composition of each cement were obtained from different suppliers: Alag fino form Kerneos Inc. (France) was used with the cement Secar 51, Chamote 70 from Togni SA (Brazil) was used with the cement Secar 71 and Aluminum oxide from Imerys Fused Minerals (Brazil) was used with the cement 
Secar 80 . The mineralogical composition of the refractory cements and aggregates are given in Table 1 and Table 2, respectively. The main differences between the three cements and aggregates used was the content of $\mathrm{Al}_{2} \mathrm{O}_{3}$ and $\mathrm{CaO}$. The adopted aggregates particle size distribution ranges from $0.001 \mathrm{~mm}$ to $1.18 \mathrm{~mm}$ in diameter. A Polycarboxilate superplasticizer (Peramin CONPAC 500 from Kerneos Inc.) and a viscosity modifier agent type Rheomac UW 410 (VMA) were used to modify the material rheology. The reason for the selection of this particular combination was mainly the chemical compatibility between aggregates and cements provided by the manufacturer Kerneos.

Table 1 - Physical and chemical characteristics of refractory cements

\begin{tabular}{|c|c|c|c|}
\hline $\begin{array}{c}\text { Chemical Composition } \\
\text { (\%w) }\end{array}$ & $\begin{array}{l}\text { Cement } \\
\text { SECAR } 51\end{array}$ & $\begin{array}{l}\text { Cement } \\
\text { SECAR } 71\end{array}$ & $\begin{array}{l}\text { Cement } \\
\text { SECAR } 80\end{array}$ \\
\hline $\mathrm{Al}_{2} \mathrm{O}_{3}$ & $50.8-54.2$ & $68.7-70.5$ & $79.5-82.0$ \\
\hline $\mathrm{CaO}$ & $35.9-38.9$ & $28.5-30.5$ & $16.2-17.8$ \\
\hline $\mathrm{SiO}_{2}$ & $4.0-5.5$ & $0.2-0.6$ & 0.35 \\
\hline $\mathrm{Fe}_{2} \mathrm{O}_{3}$ & $1.0-2.2$ & $0.1-0.3$ & 0.2 \\
\hline Flow after $\mathbf{3 0} \mathrm{min}(\%)$ & 100 & 90 & 120 \\
\hline Specific gravity $\left(\mathrm{g} / \mathrm{cm}^{3}\right)$ & $2.95-3.05$ & $2.90-3.05$ & $3.2-3.3$ \\
\hline \multicolumn{4}{|l|}{ Compressive Strength } \\
\hline $\begin{array}{l}\text { After drying at } 110^{\circ} \mathrm{C} \text { for } 24 \\
\mathrm{~h}(\mathrm{MPa})\end{array}$ & 68 & 70 & 80 \\
\hline
\end{tabular}

Table 2 - Refractory aggregates characteristics

\begin{tabular}{lccc}
\hline $\begin{array}{l}\text { Chemical } \\
\text { Composition (\%w) }\end{array}$ & ALAG Fino & Chamote 70 & Aluminum Oxide \\
\hline $\mathrm{Al}_{2} \mathrm{O}_{3}$ & 39.88 & 70.80 & 99.66 \\
\hline $\mathrm{CaO}$ & 36.02 & - & - \\
\hline $\mathrm{SiO}_{2}$ & 2.79 & 19.90 & 0.02 \\
\hline $\mathrm{Fe}_{2} \mathrm{O}_{3}$ & 14.48 & 1.90 & 0.07 \\
\hline $\mathrm{TiO}_{2}$ & 1.61 & 6.50 & - \\
\hline $\mathrm{Na}_{2} \mathrm{O}$ & - & 0.50 & 0.25 \\
\hline & & & \\
\hline Physical Properties & 3.03 & & 3.96 \\
\hline Apparent Density $\left(\mathrm{g} / \mathrm{cm}^{3}\right)$ & & 2.66 & \\
\hline
\end{tabular}


The mix design of the matrix was based on the work by Rambo et al. [7]. It was designed according to the compressible packing model (CPM) and adjusted to achieve a specific rheology. The used water-cement ratio was 0.35 . The composition mix for the refractory concretes A51, A71 and A90, with the different aggregate types and aluminum cements types are given in Table 3 .

Table 3 - Concrete mixtures composition

\begin{tabular}{lccc}
\hline Materials & A51 & A71 & A90 \\
\hline Aggregate $\left(\mathbf{k g} / \mathrm{m}^{\mathbf{3}}\right)$ & 1416 & 1344 & 1649 \\
\hline Aluminous Cement $\left(\mathbf{k g} / \mathrm{m}^{\mathbf{3}}\right)$ & 750 & 712 & 873 \\
\hline Superplasticizer $\left(\mathrm{kg} / \mathrm{m}^{\mathbf{3}}\right)$ & 4.87 & 4.62 & 5.67 \\
\hline Viscosity $\mathbf{m o d i f i e r}$ agent VMA $\left(\mathrm{kg} / \mathrm{m}^{\mathbf{3}}\right)$ & 0.56 & 0.53 & 0.65 \\
\hline Water $\left(\mathbf{k g} / \mathrm{m}^{\mathbf{3}}\right)$ & 263 & 249 & 306 \\
\hline Super plasticizer content $(\%)$ & 0.65 & 0.65 & 0.65 \\
\hline Water/cement ratio & 0.35 & 0.35 & 0.35 \\
\hline
\end{tabular}

The refractory concretes were produced in a $5 \mathrm{~L}$ planetary mixer. The mixing process was performed in a room with controlled temperature $\left(\mathrm{T}=24^{\circ} \mathrm{C} \pm 1^{\circ} \mathrm{C}\right)$. First the dry materials were mixed for 1 minute at $139 \mathrm{rpm}$, prior to the water addition. The mixture was then blended for 4 min. Finally, the viscosity modifying agent was added after 4 min of mixing. The chemical composition (\% weight) were obtained by means of X-ray fluorescence analysis (XRF). These results are presented in Table 4.

Table 4 - Chemical Analysis Refractory Concretes

\begin{tabular}{lccc}
\hline Components (\%w) & A51 & A71 & A90 \\
\hline $\mathrm{Al}_{2} \mathbf{O}_{3}$ & 49.42 & 72.23 & 90.14 \\
\hline $\mathrm{CaO}$ & 35.70 & 14.27 & 9.75 \\
\hline $\mathrm{Fe}_{2} \mathrm{O}_{3}$ & 8.20 & 1.45 & 0.09 \\
\hline $\mathrm{SiO}_{2}$ & 4.15 & 6.98 & 0.01 \\
\hline $\mathrm{TiO}_{2}$ & 1.74 & 3.95 & - \\
\hline $\mathrm{BaO}$ & - & 0.91 & - \\
\hline $\mathrm{K}_{2} \mathrm{O}$ & 0.40 & - & - \\
\hline $\mathrm{MnO}_{2}$ & 0.13 & - & - \\
\hline $\mathrm{V}_{2} \mathrm{O}_{5}$ & 0.10 & - & - \\
\hline $\mathrm{Cr}_{2} \mathrm{O}_{3}$ & 0.07 & - & - \\
\hline
\end{tabular}




\begin{tabular}{llll}
\hline $\mathrm{ZrO}_{2}$ & 0.07 & 0.14 & - \\
\hline $\mathrm{SrO}$ & 0.03 & 0.01 & - \\
\hline
\end{tabular}

\subsection{Drying and firing regime}

The cylindrical samples molded in steel shapes were cured for 7 days in a controlled lab condition $\left(\mathrm{T}=24^{\circ} \mathrm{C}\right.$ and $\left.\mathrm{RH}=80 \%\right)$ and then fired at $150,300,600$, 1000 and $1200^{\circ} \mathrm{C}$ for $1 \mathrm{~h}$. It is verified that with only 7 days the refractory matrix reaches about $90 \%$ of the strength and $80 \%$ of the modulus of elasticity reached at 28 days. This behavior was also verified elsewhere [7]. The applied heating rate was set to $5^{\circ} \mathrm{C} / \mathrm{min}$. The specimens were left to cool off naturally inside the furnace in order to avoid a thermal shock. An electric furnace SPLabor 1200 was used. After cooling, the samples were removed. The cooling process was not controlled, i.e., they were allowed to cool off naturally.

\subsection{Compressive test}

Mechanical compressive tests were performed based on ASTM C133 Cold Crushing Strength and Modulus of Rupture of Refractories. Compression tests were performed in a servo hydraulic universal testing machine model MTS 810 . The cured and fired samples were tested at 7 days of age. Three cylindrical specimens were tested per temperature condition and concrete type, corresponding to a total of 54 specimens measuring $50 \mathrm{~mm}$ x $100 \mathrm{~mm}$ (diameter $\mathrm{x}$ height). The mechanical tests were evaluated at room temperature. A head block with a spherical kneecap was used on the flat surface of the sample. The tests were controlled by the actuator displacement at a rate of $0.4 \mathrm{~mm} / \mathrm{min}$. The axial strain was measured using two LVDT's attached to the sample by acrylic rings. From the stress-strain curves of 
the compression tests, the elastic modulus was computed in the linear elastic section of the curves, up to $40 \%$ of the maximum compressive strength.

\subsection{Materials characterization}

\subsubsection{X-ray diffraction}

The mineralogical composition of the thermally treated refractory concretes was determined by qualitative X-ray diffraction (XRD) analysis. The equipment used was a Bruker D4 Endeavor diffractometer, using Fe-filtered $\mathrm{CoK} \alpha_{1,2}$ radiation

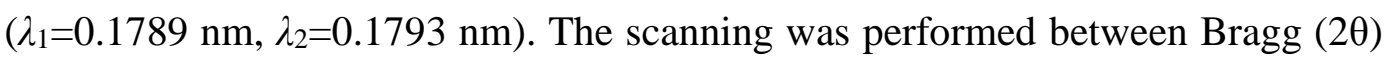
angles of 3 and $105^{\circ}$, with an angular velocity of $0.02^{\circ} / \mathrm{s}$. The analysis of the results was done in the software X'Pert HighScore Plus, using the database PDF02 (ICDD, 2006).

\subsubsection{Thermogravimetric analysis (TGA) and differential scanning} calorimetry (DSC)

The phase thermal evolution in the refractory materials with the increase of temperature was determined by thermogravimetric analysis and differential scanning calorimetry. The instrument used was the SDT Q600 model that can simultaneously run thermogravimetric, differential thermal and differential scanning calorimetry analyses. The tests were performed at temperatures ranging between 35 and $1400^{\circ} \mathrm{C}$ under air at a heating rate of $10^{\circ} \mathrm{C} / \mathrm{min}$.

\subsubsection{Porosity}

The open porosity of the specimens was measured according to the Brazilian standard NBR 9779/93. The measurements were taken in cylindrical specimens of 
$100 \mathrm{~mm}$ diameter and $50 \mathrm{~mm}$ in height. The weights of the dried $\left(\mathrm{M}_{\mathrm{s}}\right)$, saturated $\left(\mathrm{M}_{\mathrm{sat}}\right)$ and submersed ( $\left.\mathrm{M}_{\text {sub }}\right)$ specimens were used to calculate the values according to the following equations (3-5):

$$
\begin{gathered}
n=\frac{V_{v}}{V} \\
V_{v}=\frac{M_{s a t}-M_{s}}{\rho_{w}} \\
V=\frac{M_{s a t}-M_{s u b}}{\rho_{w}}
\end{gathered}
$$

Where $\mathrm{n}=$ Porosity, $\mathrm{V}_{\mathrm{v}}=$ Pores $\left(\right.$ void) volume, $\mathrm{V}=$ Sample volume, $\rho_{\mathrm{w}}=$ Density of water.

\section{Results and Discussion}

\subsection{XRD and thermal analysis}

\subsubsection{XRD qualitative analysis}

At room temperature, the main calcium aluminate cement hydration products $\mathrm{CAH}_{10}$ and $\mathrm{C}_{2} \mathrm{AH}_{8}$ were found in the concretes from X-ray diffraction analysis (see Figure 1). This was also observed by other authors [11], [12]. The presence of the alumina phase, ICDD file number 46-1212, for each refractory concrete was verified, i.e., as a minor phase for A51, as an intermediate phase for A71 and as a main phase for A90. X-ray diffraction peaks with low intensity generally correspond to the impurities that accompany the components [1]. Peaks corresponding to CA were detected in greater numbers for the A51 concrete than for the A71 and the A90 for the cured samples. These different amounts of CA influence the concretes properties after firing. 


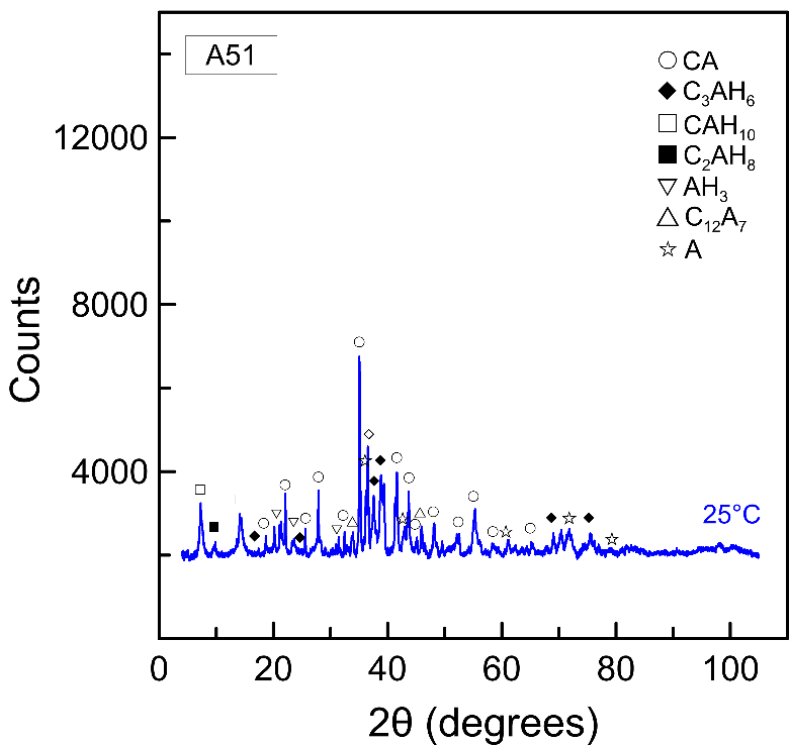

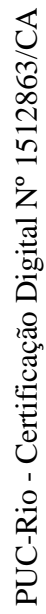
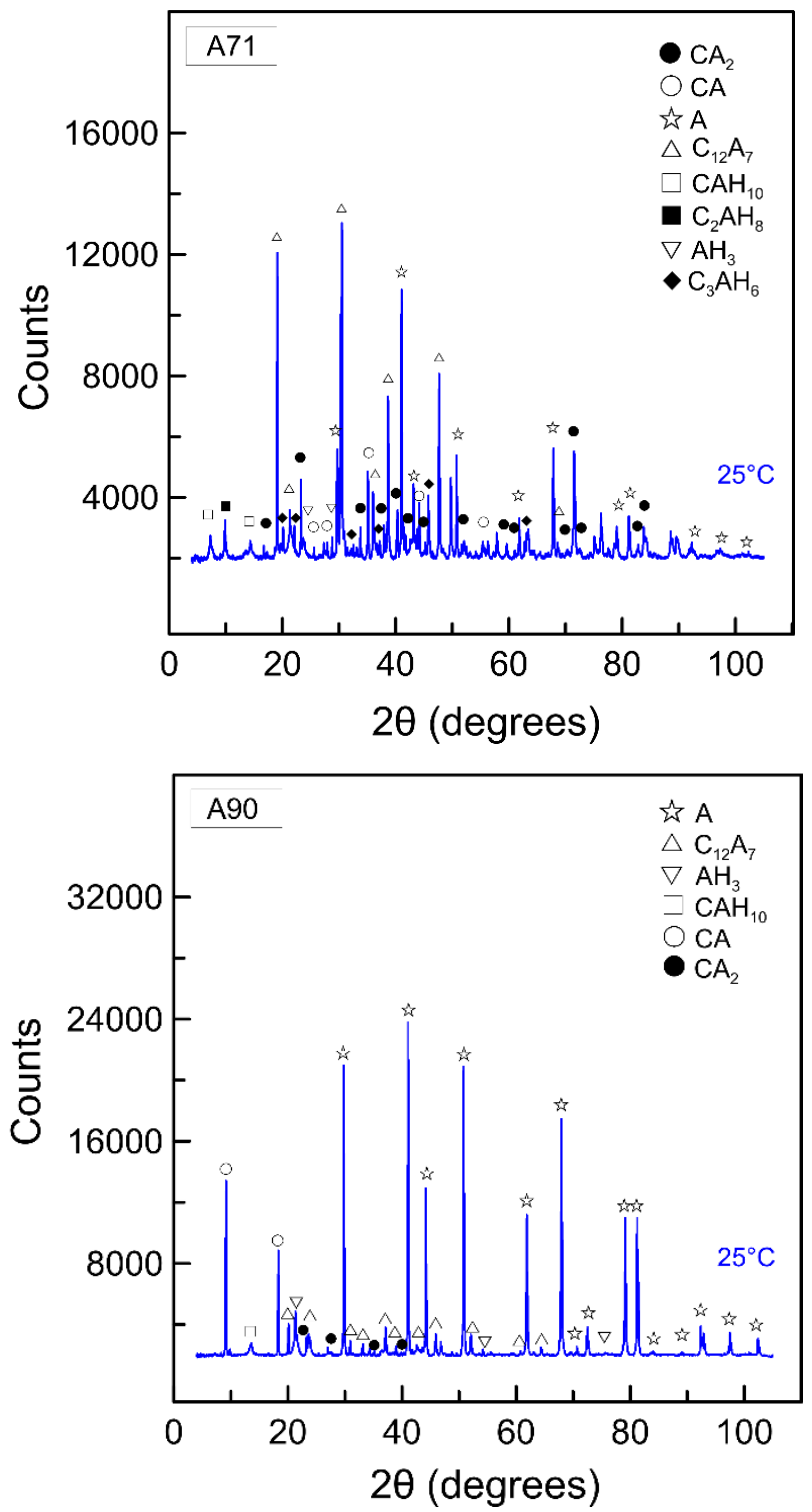

Figure 1 - XRD profiles for refractory concrete only cured: (a) A51, (b) A71, (c) A90. 
When the temperature increases the metastable hydrates $\left(\mathrm{CAH}_{10}\right.$ and $\left.\mathrm{C}_{2} \mathrm{AH}_{8}\right)$ and the stable hydrates $\left(\mathrm{AH}_{3}\right.$ and $\left.\mathrm{C}_{3} \mathrm{AH}_{6}\right)$ decompose to form $\mathrm{A}, \mathrm{C}(\mathrm{CaO}), \mathrm{C}_{12} \mathrm{~A}_{7}$, $\mathrm{CA}$ and $\mathrm{CA}_{2}$ and even $\mathrm{CA}_{6}$, depending on the amount and reactivity of the alumina initially present [25]. The XRD analyses for the tested refractories subjected to different temperatures showed similar mineralogical stoichiometry although with different intensities (counts) as shown in Figures 2a, 2b, 2c.

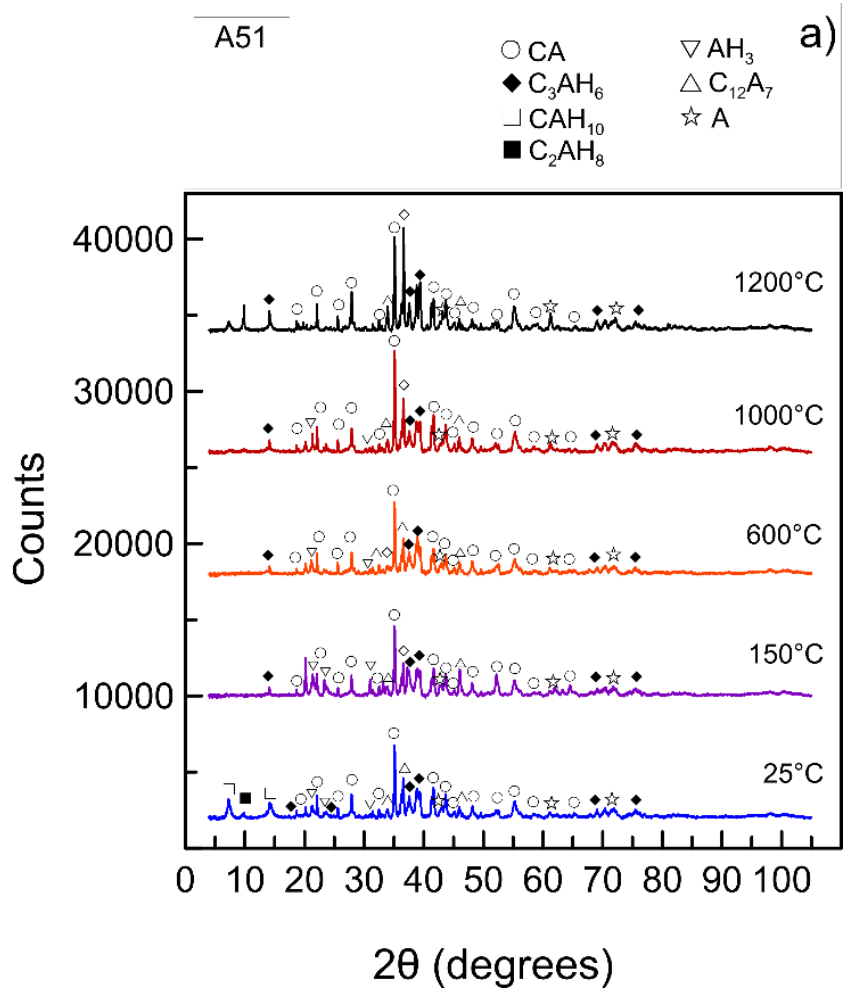




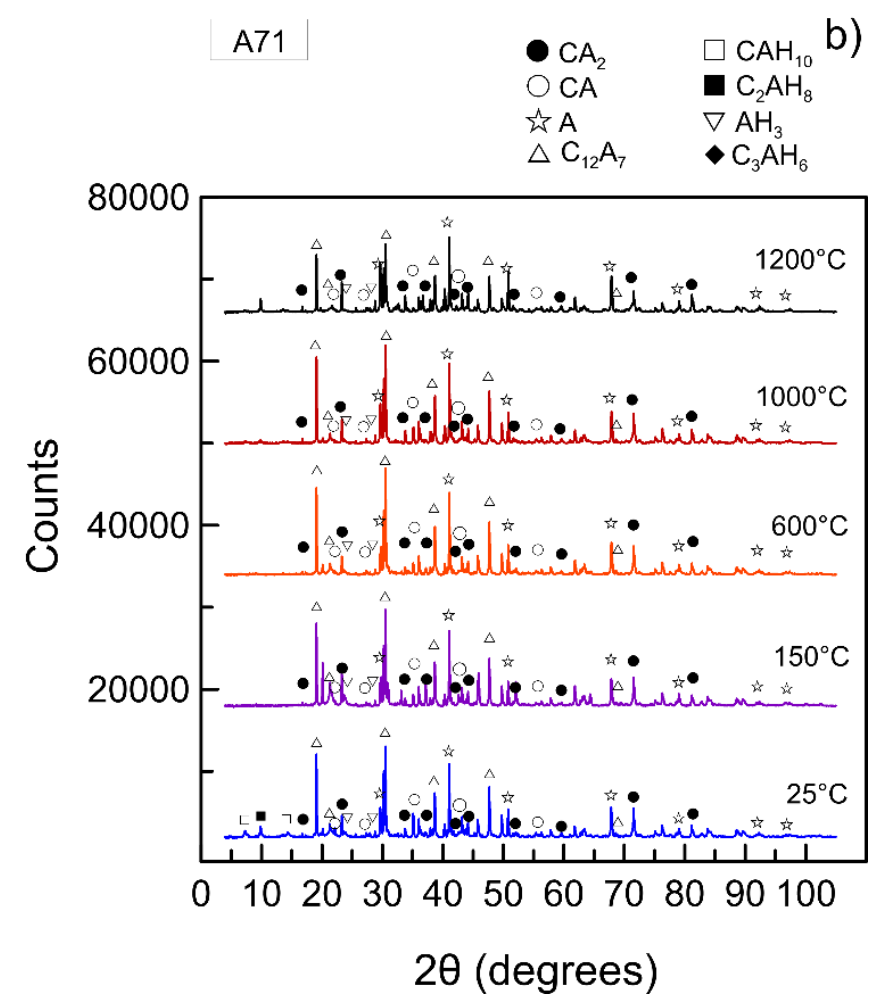

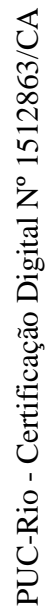

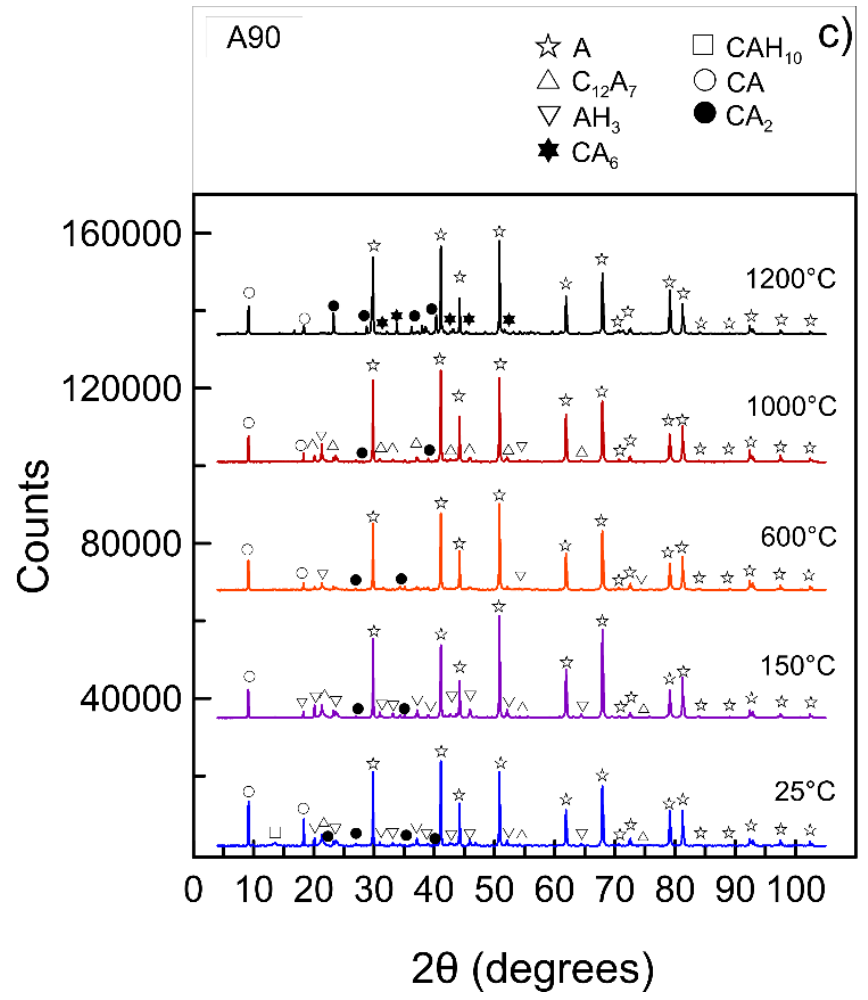

Figure 2 - XRD profiles for A51, A71 and A90 refractory concretes at room temperature and fired at $150,600,1000$ and $1200^{\circ} \mathrm{C}$. 
The evolution of the mineralogical phases with firing temperature determined by $\mathrm{X}$-ray diffraction. At $150^{\circ} \mathrm{C}$ the dehydration process takes place, therefore the diffraction peaks corresponding to the $\mathrm{CAH}_{10}$ and $\mathrm{C}_{2} \mathrm{AH}_{8}$ are not detected. The three refractory concretes showed increased peaks for $\mathrm{CA}$ and gibbsite $\mathrm{AH}_{3}$ at $150^{\circ} \mathrm{C}$. Broad diffraction peaks, such as hydration and aluminum hydroxide products, indicate low crystallinity, while narrow peaks such as CA show high crystallinity.

Between 300 and $600^{\circ} \mathrm{C}$ all refractory concretes showed a decrease in the diffraction peak for $\mathrm{CA}$ and $\mathrm{AH}_{3}$ in relation to that observed at $150^{\circ} \mathrm{C}$. This is because $\mathrm{AH}_{3}$ and $\mathrm{C}_{3} \mathrm{AH}_{6}$ gradually decompose to amorphous anhydrous phases and water vapor. Between 600 to $1000^{\circ} \mathrm{C}$ the previously stable hydrates $\mathrm{C}_{3} \mathrm{AH}_{6}$ continue to dehydrate progressively to $\mathrm{C}_{12} \mathrm{~A}_{7}$ and simultaneously, gibbsite $\mathrm{AH}_{3}$ is transformed into Alumina hydrate relics [26].

Above $1000^{\circ} \mathrm{C}$, calcium aluminate cement phases re-crystallize from the reaction between free Alumina and $\mathrm{C}_{12} \mathrm{~A}_{7}$ to form $\mathrm{CA}$ and followed by the progressive formation of $\mathrm{CA}_{2}$ as observed by the $\mathrm{XRD}$ analysis. This observation is more clearly seen for the concretes A51 and A71. At $1200^{\circ} \mathrm{C}$ the XRD plots exhibited an increase in the peak intensity for CA. This is evidence that a crystallization process of this phase has occurred.

Higher CA peak intensities were observed for refractory A51 than for the A71 and $\mathrm{A} 90$ at temperatures between 1000 and $1200^{\circ} \mathrm{C}$. This indicates a higher sintering for the A51, therefore, a higher recovery of the maximum strength. At this stage the alumina is consumed by the reaction $\mathrm{CA}+\mathrm{A}$ to form $\mathrm{CA}_{2}$. The formation of $\mathrm{CA}_{2}$ is accompanied by a relative volume increase [20], [22]. It was observed that starting from $1000^{\circ} \mathrm{C}$, there was a recovery of the mechanical properties in the three tested materials, which is attributed to the beginning of the formation of 
ceramic bonds (sintering), and the reduction of the porosity, which indicates the stiffening of the microstructure [20]. At temperatures greater than $1200^{\circ} \mathrm{C}, \mathrm{CA}_{2}$ reacts with $\mathrm{A}$ to produce $\mathrm{CA}_{6}$, and at higher temperatures all the $\mathrm{CA}_{2}$ is converted to $\mathrm{CA}_{6}[18,19,22]$. However, according to $\mathrm{XRD}, \mathrm{CA}_{6}$ is formed in $\mathrm{A} 90$ at $1200^{\circ} \mathrm{C}$. It is believed that this formation was anticipated in this concrete due to an excess of alumina available to react. In the end, the sintering reactions lead to ceramic bonding formations that increase the strength at higher temperatures $[26,27]$. The $\mathrm{XRD}$ analysis of samples fired at $1200^{\circ} \mathrm{C}$ indicates crystallization of this phase (CA) with different intensities for the three refractories.

The differences between the three refractory concrete compositions are expected to have an impact on their behavior at high temperatures $\left(>1000^{\circ} \mathrm{C}\right)$ with the formation of $\mathrm{CA}_{2}$ and $\mathrm{CA}_{6}$. These differences are associated with the amount of alumina present in their compositions and with the different porosity [18]. This is corroborated by the work by Lourenço et al. [28], which predicts the formation of $\mathrm{CA}_{2}$ and the consumption of alumina with the increase in temperature. Specifically, the differences in the chemical composition among the studied concretes are based on the quantity of $\mathrm{Al}_{2} \mathrm{O}_{3}, \mathrm{CaO}$ and $\mathrm{SiO}_{2}$. These main components are responsible for the mechanical characteristics that the concretes develop. It was verified that concretes with higher $\mathrm{CaO} / \mathrm{Al}_{2} \mathrm{O}_{3}$ ratio achieved higher compressive strengths [29].

\subsubsection{Thermal evolution analysis}

Figure 3 presents the thermograms of the three types of cured refractory concretes obtained by thermogravimetric analyses and derived thermogravimetry (TGA/DTG) under oxidant atmosphere. After curing, the refractory concretes were 
subjected to heating, which, depending on the temperature reached, causes changes in the phases during the process, as well as variations in their chemical composition, particularly with respect to water. As can be observed from Figure 3, for the three refractory concretes, the DTG peaks correspond to the following process: dehydration (free water and $\mathrm{AH}$ gel), loss of metastable hydrates $\left(\mathrm{CAH}_{10}\right.$ and $\left.\mathrm{C}_{2} \mathrm{AH}_{8}\right)$, the conversion reaction of metastable hydrates into stable $\left(\mathrm{AH}_{3}\right.$ and $\left.\mathrm{C}_{3} \mathrm{AH}_{6}\right)$ carbonate and sintering reactions. During sintering, the mechanical properties increase, and the development of the ceramics bonding takes place. These processes occurred within the same range of temperatures for the three materials, but with different intensities due to the amount of weight loss (TGA) in each peak process.

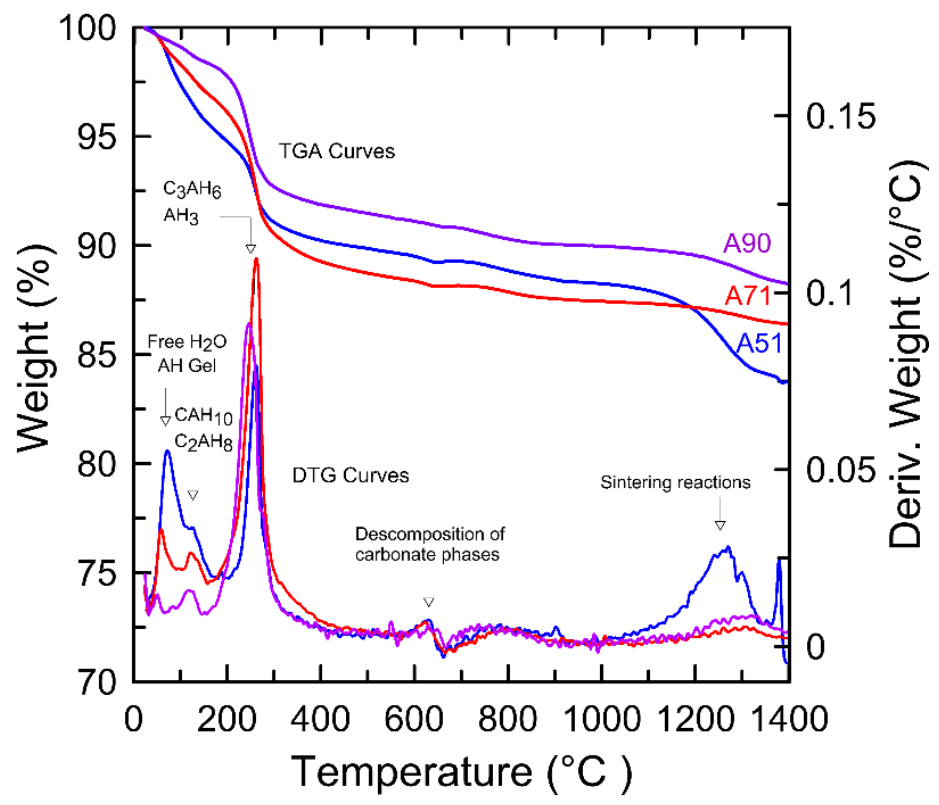

Figure 3 - TGA and DTG of A51, A71 and A90 refractory concretes only cured 
Figure 4 presents the thermograms for the three studied refractory concretes for cured samples and samples fired at $1200^{\circ} \mathrm{C}$. Samples subjected to $1200^{\circ} \mathrm{C}$ showed the same DTG peaks as samples at $25^{\circ} \mathrm{C}$, but the peaks were less marked. For example, for A51the DTG peaks between 75 and $200^{\circ} \mathrm{C}$, as can be seen from Figure 4a. This can be traced back to different processes: loss of free and structural water from the $\mathrm{AH}$ gel and dehydration of the metastable $\mathrm{CAH}_{10}$ and $\mathrm{C}_{2} \mathrm{AH}_{8}[3,4,5]$. The XRD diffractograms (refer to Figure 1) confirm this finding.

A substantial weight loss (TGA) can be observed in Figure $4 \mathrm{~b}$ for the temperature range between 200 and $350^{\circ} \mathrm{C}$, for both the unheated and heated samples of A71. This can be attributed to the dehydration of the metastable phase $\mathrm{CAH}_{10}$ and of the stable phase $\mathrm{AH}_{3}$ [11]. The DTG peak observed in Figures 4a, $4 \mathrm{~b}, 4 \mathrm{c}$ from 600 to $700^{\circ} \mathrm{C}$ is a result of the decomposition of the carbonate phases $[3,4]$.

The A51 DTG peaks with considerable intensity at temperatures higher than $1200^{\circ} \mathrm{C}$. This is also observed for the other refractories, but with less intensity. These can be attributed to the sintering process or ceramics bonding reactions normally observed in high temperature refractory concrete applications $[30,31]$.

The three refractory concretes evolved in a similar way, with the increase of temperature on the DTG curves, resulting in the same transformations, but with different intensities. At approximately $110^{\circ} \mathrm{C}$, partial dehydration of $\mathrm{CAH}_{10}$ occurs for the three materials. Then when the temperature increases to $150^{\circ} \mathrm{C}$ the $\mathrm{CAH}_{10}$ is converted to $\mathrm{C}_{3} \mathrm{AH}_{6}$ and gibbsite $\left(\mathrm{AH}_{3}\right)$, also known as the conversion reaction. This causes an increase in the porosity of the material, and consequently, a decrease in its mechanical properties [19]. This explains, for example, the initial drastic drop 
of the A51 and A71's mechanical properties in correlation with the highest dehydration peak (Figure $7 \mathrm{a}$ and $7 \mathrm{~b}$ ), as is discussed in the next section (3.2). Similar experiments in refractory matrices have suggested that this effect is related to dehydration $[15,16,32]$. Therefore, the low DTG peaks for the A90 at this stage $\left(25-300^{\circ} \mathrm{C}\right)$ in Figure $4 \mathrm{c}$ indicate a slight variation of the mechanical behavior. For A90 the elastic modulus had little change at this temperature range (refer to Figure $8 b$ in section 3.2).

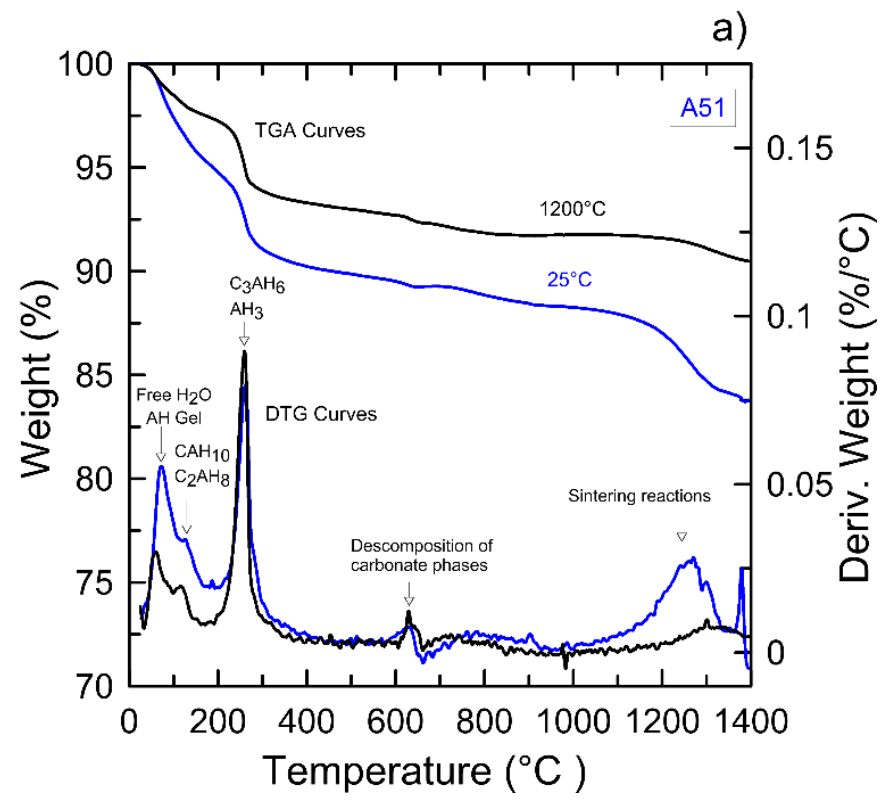




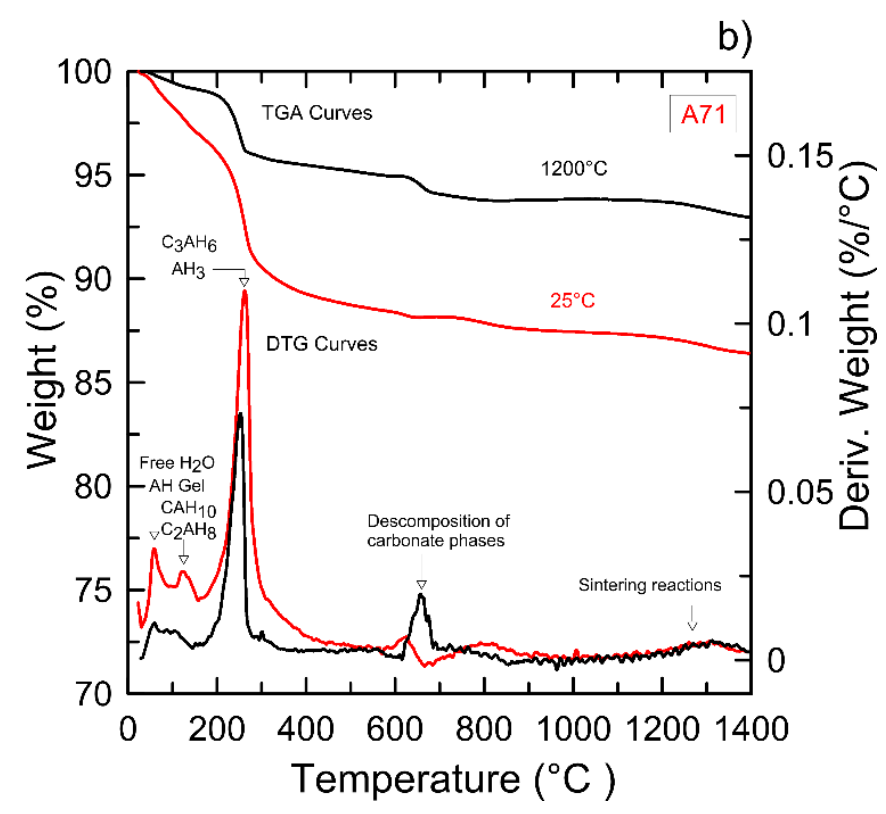

c)

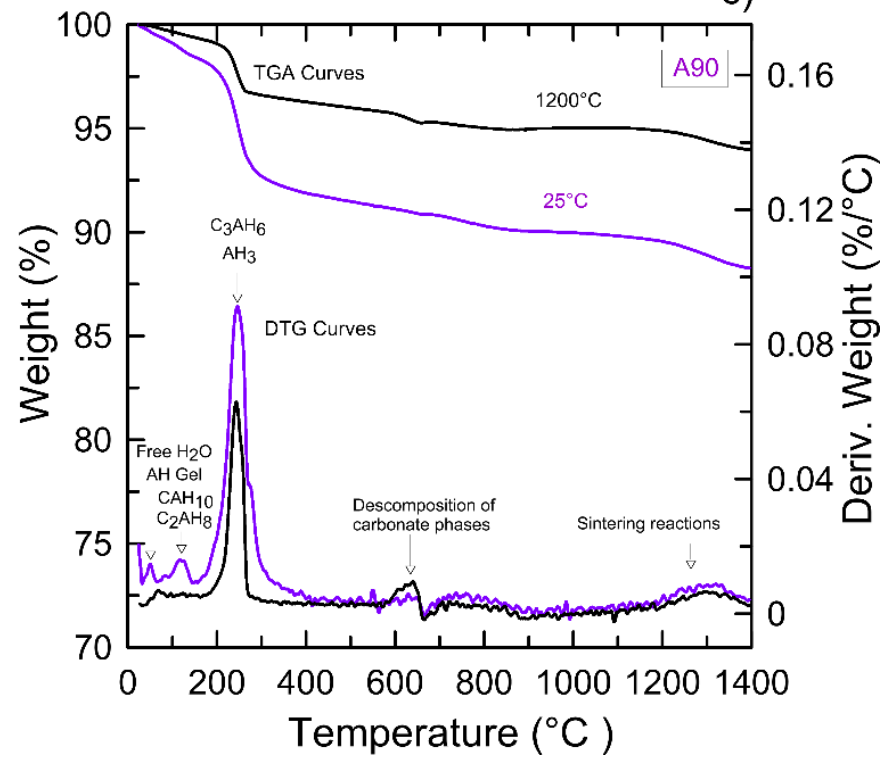

Figure 4 - Thermal analysis of the refractory concretes only cured and fired at $1200^{\circ} \mathrm{C}$ : a)

A51, b) A71 and c) A90.

Differential Scanning Calorimetry (DSC) was performed, since they allow the measurement of the enthalpy variations that occur in a material during the 
heating process [33]. When a sample undergoes some type of physical or chemical change a release or absorption of heat occurs (exothermic or endothermic peak).

Figure 5, shows the DSC curves for the three cured concretes. An endothermic peak can be observed within the $250-300^{\circ} \mathrm{C}$ temperature range for the three materials, indicating the dehydration of the stable phases. The next characteristic temperature in the DSC was displayed at $1180^{\circ} \mathrm{C}$ for the $\mathrm{A} 51,1140^{\circ} \mathrm{C}$ for the $\mathrm{A} 71$ and $1230^{\circ} \mathrm{C}$ for the $\mathrm{A} 90$; being more intense for $\mathrm{A} 51$, of medium intensity for A71 and of lower intensity for A90. These endothermic peaks showed the largest phase transformation, which can be attributed to the mechanism of crystallization of some $\mathrm{C}_{12} \mathrm{~A}_{7}$, transition product, which is still transformed to $\mathrm{CA}$, followed by the reaction with free alumina to form $\mathrm{CA}_{2}$.

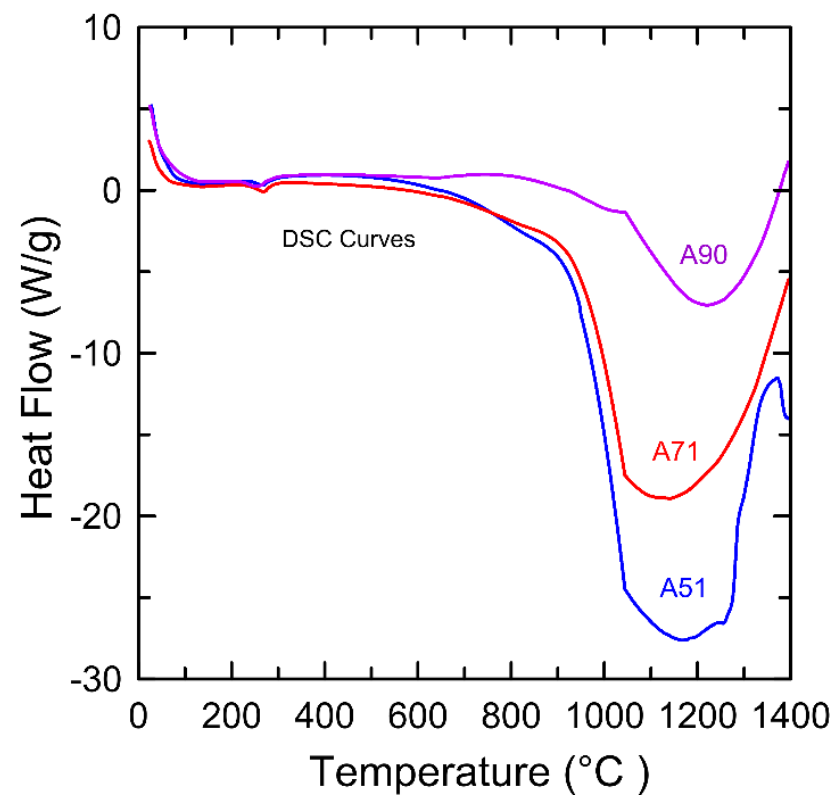

Figure 5 - DSC curves for the cured refractory concretes A51, A71 and A90. 
Above $1200^{\circ} \mathrm{C}$ the different crystalline structures undergo a transformation to a more stable phase into $\mathrm{CA}$, then $\mathrm{CA}_{2}[27,32]$. Above $1300^{\circ} \mathrm{C}$ the reaction continues, with $\mathrm{CA}_{6}$ formed from $\mathrm{CA}_{2}$ and $\mathrm{Al}_{2} \mathrm{O}_{3}$. This observation confirms the presence of a phase transformation, detected by TGA/DTG curves up to $1200^{\circ} \mathrm{C}$, known as transient liquid phase, which has also been reported in the literature [15]. From $1000^{\circ} \mathrm{C}$ to $1200^{\circ} \mathrm{C}$, expansive formations of $\mathrm{CA}_{2}$ coincide with the increase of elastic modulus and compressive strength. This reaction indicates the mechanism of bonding between the components of the refractory, i.e. the beginning of the formation of ceramic bonds by sintering. This effect strongly depends on the $\mathrm{CaO} / \mathrm{Al}_{2} \mathrm{O}_{3}$ ratios in the matrix [19]. This is consistent with the higher $\mathrm{CaO} / \mathrm{Al}_{2} \mathrm{O}_{3}$ ratio for A51 refractory concrete $(\mathrm{C} / \mathrm{A}=0.72)$, in contrast with the values obtained for $\mathrm{A} 71(\mathrm{C} / \mathrm{A}=0.20)$ and $\mathrm{A} 90(\mathrm{C} / \mathrm{A}=0.11)$, which showed a higher compressive strength at high temperatures. The different microstructures of the concretes investigated as a function of the heat process temperature, were determined to be responsible for the different levels of maximum strength and elastic modulus [34].

\subsection{Effect of temperature on the mechanical behavior}

Figure 6 shows typical stress vs. strain curves for the refractory concretes A51, A71 and A90 at ambient temperature, that is, unfired samples after 7 days of cure. 


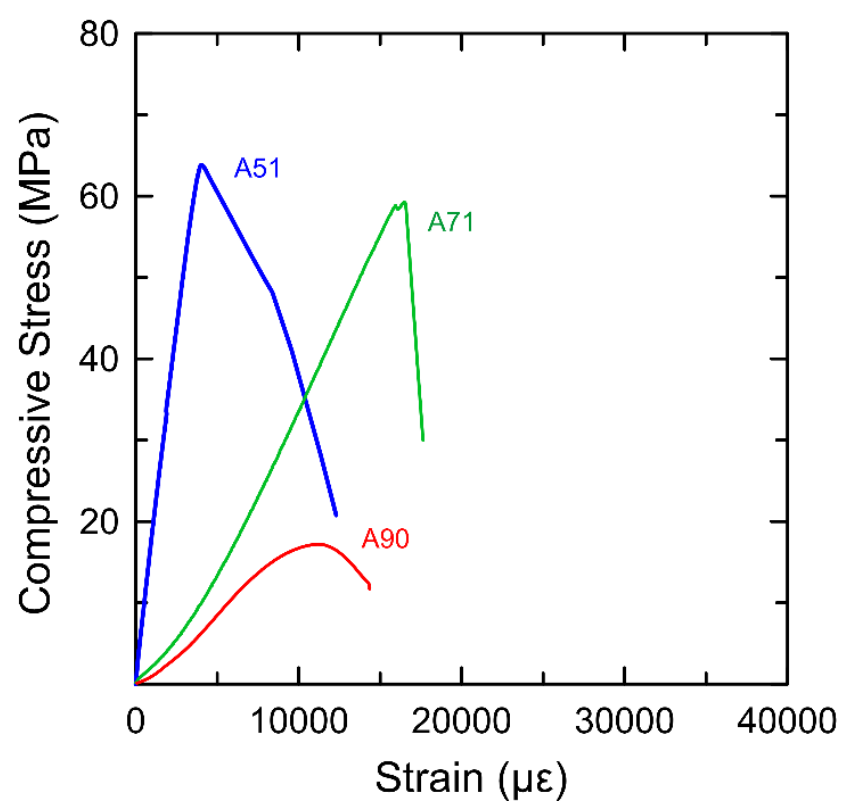

Figure 6 - Stress-strain curves of A51, A71 and A90 refractory concretes at room temperature.

Table 5 presents the summary of all results. As can be seen, the elastic modulus varies considerably amongst the three materials, with the highest value for A51 (21 GPa), followed by A71 (5 GPa) and the lowest for A90 (2.5 GPa). The compressive strength remained in the same order of magnitude for A51 and A71, while for A90 a much lower value was obtained. Although the same composition in the matrix was used for the three concretes, the different aggregates compatible with each type of cement may have influenced the mechanical properties of the concretes [30].

Table 5 - Mechanical parameters of refractory concretes at ambient temperature

\begin{tabular}{cccc}
\hline & E (GPa) & $\sigma(\mathrm{MPa})$ & $\boldsymbol{\varepsilon}$ \\
\hline A51 & $20 \pm 2.5$ & $63 \pm 3$ & $0.003 \pm 0.001$ \\
A71 & $5 \pm 1$ & $59 \pm 5$ & $0.012 \pm 0.001$ \\
A90 & $2.5 \pm 0.5$ & $17 \pm 3$ & $0.010 \pm 0.001$ \\
\hline
\end{tabular}

The calcium aluminate cements (CAC) have the phases $\mathrm{CA}, \mathrm{CA}_{2}, \mathrm{C}_{12} \mathrm{~A}_{7}$. The contact with water causes the process of hydration, forming a rigid structure in the 
refractory concrete. Several phases can be formed during hydration, with different chemical and mineralogical compositions. The crystal structures of these phases $\mathrm{AH}_{3}, \mathrm{CAH}_{10}, \mathrm{C}_{2} \mathrm{AH}_{8}$ and $\mathrm{C}_{3} \mathrm{AH}_{6}$ vary depending on the temperature range. The material formed has different relative amounts of these phases depending on various factors, curing temperature, $\mathrm{CaO} / \mathrm{Al}_{2} \mathrm{O}_{3}(\mathrm{C} / \mathrm{A})$ ratio, the amount of water and the presence of impurities in the aluminate solution and aggregates $[6,16]$. Moreover, the amount of $\mathrm{CaO}$ decreased when the amount of alumina $\left(\mathrm{Al}_{2} \mathrm{O}_{3}\right)$ increased for the three cement types. Therefore, the C/A ratio is higher for A51 and lower for A90. This also plays a role in the strength of the refractory concrete.

The compressive behavior of the refractory concrete A51 with the Alag aggregate proved to stiffer than A71 with the Chamotte 70 aggregate, since the Alag aggregate is denser $\left(3.03 \mathrm{~g} / \mathrm{cm}^{3}\right)$ than the Chamotte aggregate $\left(2.66 \mathrm{~g} / \mathrm{cm}^{3}\right)$ [35]. The refractory concrete A90 presented lower strength and elastic modulus values at ambient temperature, due to the fact that at this temperature the strength of the concrete depends mainly on the Secar 80 cement. At room temperature, the aluminum oxide aggregate does not react with the cement. The reaction with the aggregate starts only at temperatures above $1350^{\circ} \mathrm{C}$ [27]. Also, this aggregate has a finer granulometry when compared to the other aggregates [20].

The softening behavior is more evident in the refractory concrete A90 than in the other two concretes, which exhibited a more brittle response. Porosity is related to the softening behavior due to damage. Because of that, the porosity of the cured samples was determined by means of water absorption by the immersion technique. The weights of the dried, submersed and saturated samples, were used to calculate the values of specific mass and apparent porosity. The porosity values obtained at room temperature were $16 \%$ for A51, 23\% for A71 and $24 \%$ for A90. This also 
explains the differences between the results of the mechanical properties obtained in the samples at room temperature. The properties decreased with increasing porosity. At $1000^{\circ} \mathrm{C}$ the porosity of the refractory concretes A51, A71 and A90 were respectively, $27 \%, 30 \%, 32 \%$.

Figure 7 shows representative stress vs. strain curves obtained from compression tests for the refractory concretes with $51 \mathrm{wt} . \%, 71 \mathrm{wt} . \%$ and $90 \mathrm{wt} . \%$ alumina, before and after being exposed to different temperatures $(150,300,400$, 600,1000 e $\left.1200^{\circ} \mathrm{C}\right)$. During heating the refractory concretes dehydrate causing microstructural changes that can improve or reduce the mechanical strength of the refractories. Research has shown that when these materials are heated between 200 and $300^{\circ} \mathrm{C}$, their strength decreases relative cured material at room temperature $[27,32]$. The behavior of the materials as a function of temperature can be divided into two groups. The quasi-brittle behavior at lower temperatures (from 29 to $300^{\circ} \mathrm{C}$ ) and the viscoplastic behavior at higher temperatures $\left(600\right.$ to $1200^{\circ} \mathrm{C}$ ), as also observed by other authors $[1,7,12,21,36]$. The loss of strength during the conversion process can be explained by the fact that hydrated aluminate products become denser. The conversion, with the release of water, results in an increase in the porosity of the matrix. The softening behavior is mainly due to the microcracking and porosity of the material as reported by Muñoz, et al. [2], since it is well known that the elastic modulus is influenced by porosity [25]. Thus, the increase in porosity contributes to the damage of the microstructure of the material during compression, generating a larger number of microcracks, which causes a decrease in the mechanical properties.

The degree of softening was quantified from the stress-strain curves calculating the final strain to fracture strain ratio (s). It was verified that the 
softening in A90 ( $\mathrm{s}=0.96)$ is lower than in the two other refractory concretes A51 $(\mathrm{s}=1.37)$ and A71 ( $\mathrm{s}=1.64)$, which corresponds to a smaller amount of glassy phase, according the chemical composition. Considering the difference in $\mathrm{SiO}$ content between A51 and A71, this may also influence the degree of softening, since the A71 presented a higher degree and also has a higher amount of SiO.

Figure $7 \mathrm{a}$ presents representative stress-strain curves of the refractory concrete A51 obtained from compression tests at various temperatures. The first observation is a significant decrease in the material strength with the increase in temperature. A $75 \%$ decrease in the peak strength is observed when the material was tested at $1000^{\circ} \mathrm{C}$. Another singularity is the inversion of the behavior for temperatures above $1200^{\circ} \mathrm{C}$. An increase in the peak strength is observed when compared to the peak strength obtained at $300^{\circ} \mathrm{C}$. Similar behavior was noted in the other two materials. For higher temperatures (from 600 to $1000^{\circ} \mathrm{C}$ ) an increase in the non-linearity and plastic strain is seen, indicating the reduction in the viscosity of the glassy phase [6]. This glassy phase is formed in the refractory compositions by the reaction of $\mathrm{CaO}$ with $\mathrm{Al}_{2} \mathrm{O}_{3}$ and $\mathrm{SiO}_{2}$. It occurs from $600^{\circ} \mathrm{C}$ and above. The A51 concrete presented the highest compressive strength for all studied temperatures. Furthermore, an increase in compressive strength at $1200^{\circ} \mathrm{C}$ is observed. At $1200^{\circ} \mathrm{C}$ the $\mathrm{A} 51$ concrete showed an appreciable increase in the value of the modulus of elasticity attributed to the increase in $\mathrm{CA}_{2}$ concentration and the beginning of sintering reactions [28].

The A71 refractory concrete (Figure $7 b$ ) also experienced a decrease in the compressive strength between ambient temperature and $1000^{\circ} \mathrm{C}$. Amongst the three tested concretes, A71 showed the highest peak stress drop, estimated at $80 \%$. The non-linear behavior of this material was more pronounced between $600^{\circ} \mathrm{C}$ and 
$1000^{\circ} \mathrm{C}$, with greater ability to deform. At $1200^{\circ} \mathrm{C}$, it exhibited an increase in the peak strength, as did A51.

The A90 material showed (Figure 7c) an inverse behavior to the other two materials, that is, a strength gain in relation to the ambient temperature was observed for the temperatures of $150^{\circ} \mathrm{C}, 300^{\circ} \mathrm{C}$ and $600^{\circ} \mathrm{C}$. This mechanical evolution was also reported by other studies with $80 \%$ of alumina $[7,11]$. A viscous behavior was noticed at 600 and $1000^{\circ} \mathrm{C}$. At $1200^{\circ} \mathrm{C}$ the material also experienced an increase in the strength when compared to $1000^{\circ} \mathrm{C}$. Of the three tested concretes, the A90 concrete presented the lowest strength drop between ambient temperature and $1000^{\circ} \mathrm{C}$, which was calculated to be $18 \%$. Similar to the other two materials, an increase in the strength value was observed at $1200^{\circ} \mathrm{C}$. This increase was $15 \%$ higher when compared to the strength in ambient temperature. These differences are related to the material strain capacity, which is due to its alumina content and type of aggregate, as verified in the chemical analyses $[1,2,13]$, since the type of aggregate contributed with the addition of free alumina for this transformation [25].

a)

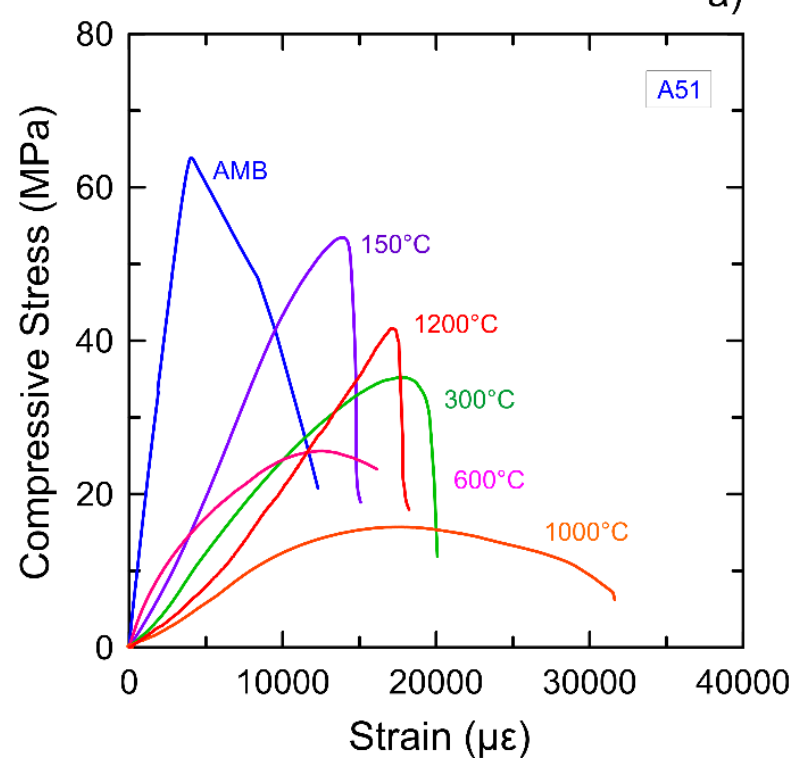


b)

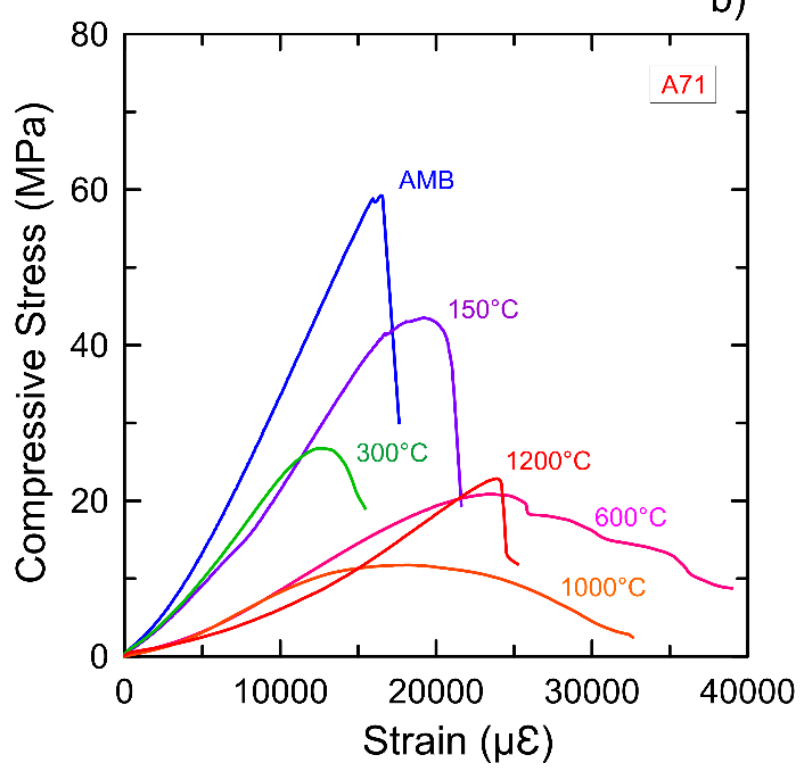

c)

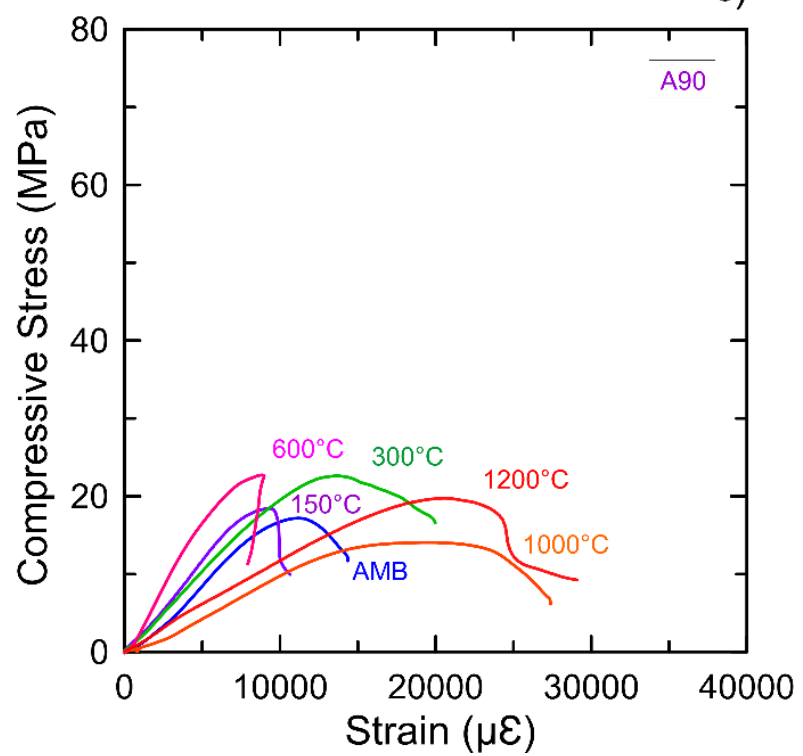

Figure 7 - Stress-strain curves for refractory concrete at different firing temperatures: (a) A51, (b) A71, (c) A90.

Figure 8 summarizes the values of ultimate strength and elastic modulus for all materials and temperatures. The shape of the curves shows an evolution with almost linear behavior in the beginning, then becoming nonlinear until the peak force, followed by a sharp decrease or softening behavior. The decrease in the 
compression stress is related to a phase change in the material as the temperature increases. This is mainly caused by the conversion process and dehydration [4]. The elastic modulus at $1000^{\circ} \mathrm{C}$ for A51, A71 and A90 is practically reduced to the same value (approximate to $1.2 \mathrm{GPa}$ ). Therefore, above $1200^{\circ} \mathrm{C}$ the refractory concretes exhibited a shrinkage associated with sintering, which also involves appreciable increase in the elastic modulus [19]. This increase in the elastic modulus was higher for the A51 concrete. This can be related to the greater amount of calcium aluminate (CA) that is formed and reacts with the free Alumina when compared with the other two refractories A71 and A90.

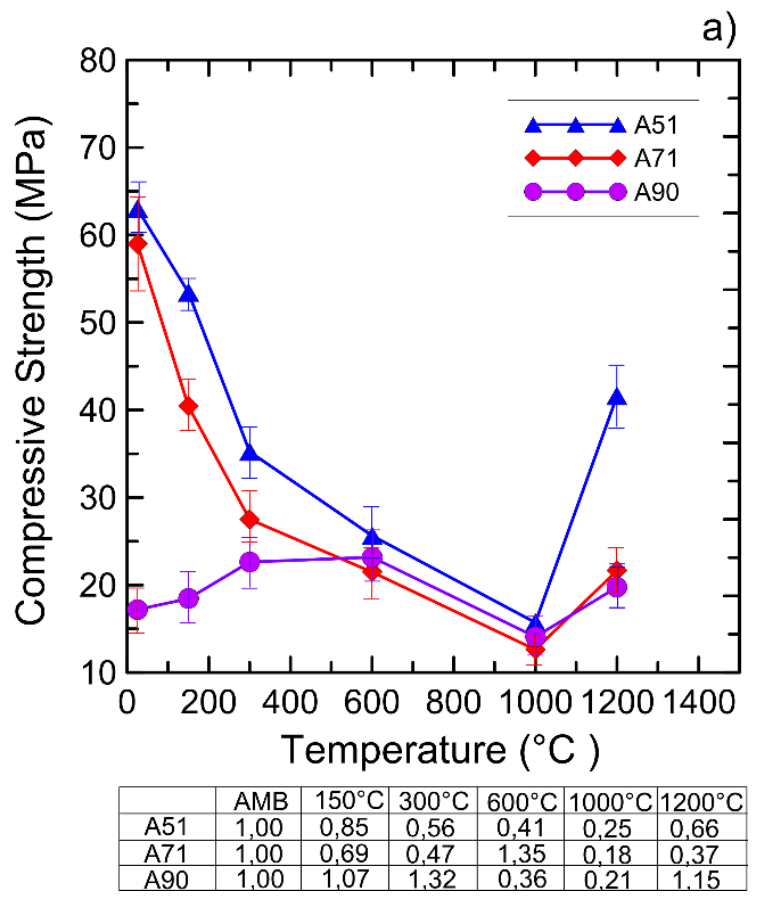


b)

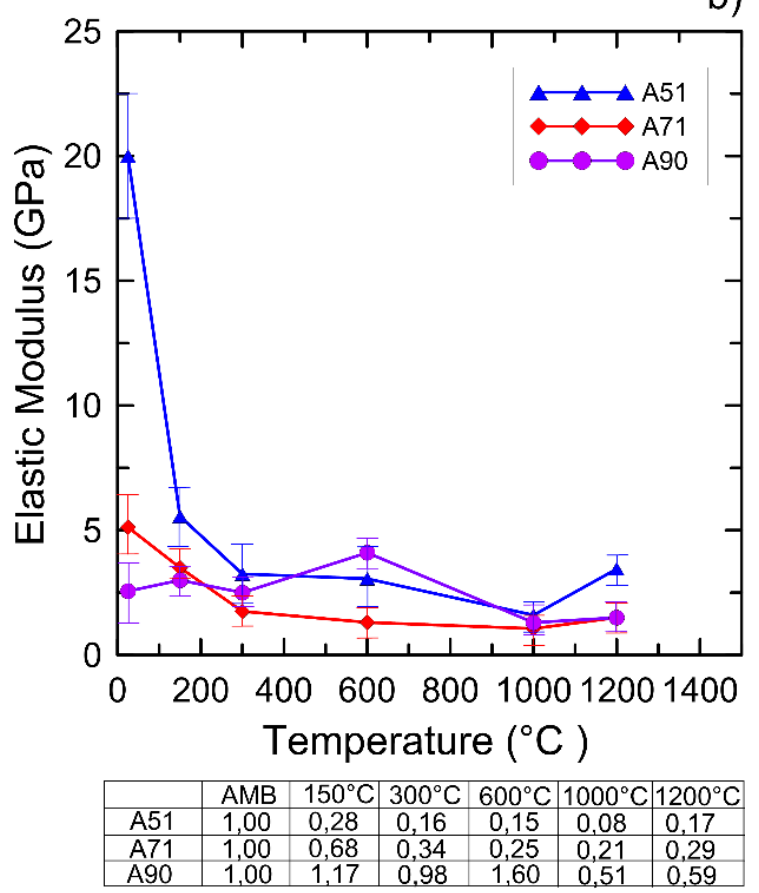

Figure $8-$ Variation in the mechanical properties of refractory concretes with the firing temperature: (a) Compressive Strength, (b) Elastic Modulus

The mechanical behavior of the refractory concretes depends on various factors, such as changes in the CAC phases, the evolution of hydrates with temperature, and particle sizes [2,37]. The differences of some measured properties of the three refractory concretes can be correlated with different size and size distributions of the aggregates [38]. This greater difference is probably related to matrix/aggregate interaction, since the aggregates in the refractory A51 are larger than those in refractory A71 and A90. In order to explain the chemical variations of each refractory concrete, mineralogical and thermal analyses were also performed. 


\section{Conclusions}

Residual compression tests were done on refractory concretes with different alumina contents $50 \mathrm{wt} . \%, 70 \mathrm{wt} . \%$ and $90 \mathrm{wt} . \%$. The testing temperatures were 25 , $150,300,600,1000$ and $1200^{\circ} \mathrm{C}$. Analytical techniques, such as XRD diffraction analysis, TGA and DSC were used for material characterization and thermal evolution with increasing temperature. The following conclusions can be drawn from the present work:

- The chemical behavior analyses for the different temperatures showed a similar mineralogical stoichiometry for the three refractories, but with different intensities due to the different composition of each concrete refractory, which influences the mechanical response.

- The mechanical behavior of the refractory concretes was found to be very different and mainly influenced by the mineralogical composition of the matrix components. That is, the $\mathrm{CaO}$ content of the aluminous cement and the type of aggregate were determinant.

- The mechanical behavior when firing temperature increased exhibited a significant drop in compressive strength and modulus of elasticity for the $51 \mathrm{wt} . \%$ and $71 \mathrm{wt} . \%$ alumina refractory concretes. However, the refractory concrete with $90 \mathrm{wt} . \%$ alumina showed a more stable mechanical behavior, maintaining to a certain extent, the mechanical properties.

- At high temperatures between 1000 and $1200^{\circ} \mathrm{C}$, when the sintering process only begins, the expansive formation of $\mathrm{CA}_{2}$ leads to the increase of the compressive strength and modulus of elasticity in all the refractory concretes studied. This effect is strongly dependent on the $\mathrm{CaO} / \mathrm{Al}_{2} \mathrm{O}_{3}$ ratio of the matrix components. 


\section{Acknowledgements}

This work was supported by FAPERJ, CNPq, PUC-Rio and Kerneos aluminate technologies.

\section{References}

[1] V. Muñoz, P. Pena, A.G.T. Martínez, Physical, chemical and thermal characterization of alumina-magnesia-carbon refractories, Ceram. Int. 40 (2014) 9133-9149. doi:10.1016/j.ceramint.2014.01.128.

[2] V. Muñoz, A.G.T. Martinez, Factors controlling the mechanical behavior of alumina-magnesia-carbon refractories in air, Ceram. Int. 42 (2016) 1115011160. doi:10.1016/j.ceramint.2016.04.021.

[3] M. Nouri-Khezrabad, A.P. Luz, V.R. Salvini, F. Golestani-Fard, H.R. Rezaie, V.C. Pandolfelli, Developing nano-bonded refractory castables with enhanced green mechanical properties, Ceram. Int. 41 (2015) 3051-3057. doi:10.1016/j.ceramint.2014.10.143.

[4] E. Nonnet, N. Lequeux, P. Boch, Elastic properties of high alumina cement castables from room temperature to $1600^{\circ} \mathrm{C}$, J. Eur. Ceram. Soc. 19 (1999) 1575-1583. doi:10.1016/S0955-2219(98)00255-6.

[5] N. Schmitt, J.F. Hernandez, V. Lamour, Y. Berthaud, P. Meunier, J. Poirier, Coupling between kinetics of dehydration, physical and mechanical behaviour for high alumina castable, Cem. Concr. Res. 30 (2000) 15971607. doi:10.1016/S0008-8846(00)00342-2.

[6] W.E.L. H. Sarpoolaky, K.G. Ahari, Influence of in situ phase formation on properties of calcium zirconate refractories, J. Eur. Ceram. Soc. 37 (2002) 487-493. doi:10.1016/j.jeurceramsoc.2016.08.017.

[7] D.A.S. Rambo, F. de Andrade Silva, R.D. Toledo Filho, O. da Fonseca Martins Gomes, Effect of elevated temperatures on the mechanical behavior of basalt textile reinforced refractory concrete, Mater. Des. 65 (2015) 24-33. doi:10.1016/j.matdes.2014.08.060.

[8] D.A. Strauss Rambo, F. De Andrade Silva, R.D. Toledo Filho, N. Ukrainczyk, E. Koenders, Tensile strength of a calcium-aluminate cementitious composite reinforced with basalt textile in a high-temperature environment, Cem. Concr. Compos. 70 (2016) 183-193. doi:10.1016/j.cemconcomp.2016.04.006.

[9] C. Wöhrmeyer, C. Parr, H. Fryda, E. Frier, New Calcuim Aluminate Aggregates for Refractory Castables Installed in Highly Abrasive Environments, 16th Conf. Refract. Silic. Soc. Prague, Czech Repub. (2011) $1-13$.

[10] E.F. C. Wöhrmeyer, C. Parr, H. Fryda, Aggregates for non-ferrous 
Applications, Refract. World Forum, Ed. 2/2011. (2012) 1-12.

[11] D.A. Strauss Rambo, F. De Andrade Silva, R.D. Toledo Filho, N. Ukrainczyk, E. Koenders, Exposing Calcium aluminate mortar to high temperatures: Overcoming adverse conversion effects using clinker aggregates, Cem. Concr. Res. (2016).

[12] F. Benali, M. Hamidouche, H. Belhouchet, N. Bouaouadja, G. Fantozzi, Thermo-mechanical characterization of a silica-alumina refractory concrete based on calcined algerian kaolin, Ceram. Int. 42 (2016) 9703-9711. doi:10.1016/j.ceramint.2016.03.059.

[13] V. Munoz, A.G. Tomba Martinez, Thermal Evolution of Al2O3-MgO-C Refractories, Procedia Mater. Sci. 1 (2012) 410-417. doi:10.1016/j.mspro.2012.06.055.

[14] H. Marzagui, T. Cutard, Characterisation of microstructural evolutions in refractory castables by in situ high temperature ESEM, J. Mater. Process. Technol. 155-156 (2004) 1474-1481. doi:10.1016/j.jmatprotec.2004.04.365.

[15] F. Simonin, C. Olagnon, S. Maximilien, G. Fantozzi, Thermomechanical Behavior of High-Alumina Refractory Castables with Synthetic Spinel Additions, J. Am. Ceram. Soc. 83 (2000) 2481-2490. doi:10.1111/j.11512916.2000.tb01579.x.

[16] J.M. Auvray, C. Gault, M. Huger, Evolution of elastic properties and microstructural changes versus temperature in bonding phases of alumina and alumina-magnesia refractory castables, J. Eur. Ceram. Soc. 27 (2007) 3489-3496. doi:10.1016/j.jeurceramsoc.2007.01.016.

[17] L.A. Díaz, R. Torrecillas, F. Simonin, G. Fantozzi, Room temperature mechanical properties of high alumina refractory castables with spinel, periclase and dolomite additions, J. Eur. Ceram. Soc. 28 (2008) 2853-2858. doi:10.1016/j.jeurceramsoc.2008.04.019.

[18] D.A.S. Rambo, Y. Yao, F. de Andrade Silva, R.D. Toledo Filho, B. Mobasher, Experimental investigation and modelling of the temperature effects on the tensile behavior of textile reinforced refractory concretes, Cem. Concr. Compos. 75 (2017) 51-61. doi:10.1016/j.cemconcomp.2016.11.003.

[19] L. Scheinherrová, M. Dolez, M. Keppert, E. Vejmelková, D. Kon, C. Robert, Virtual Special Issue Durability of Innovative Construction Materials and Structures High temperature durability of fiber reinforced high alumina cement composites, 162 (2018) 881-891. doi:10.1016/j.conbuildmat.2018.01.076.

[20] D. Zhang, C. Li, N. Jiang, J. Gao, B. Touzo, W. Yuan, In fl uence of powder characteristics of reactive alumina on properties of alumina-spinel castables, Ceram. Int. 44 (2018) 9984-9990. doi:10.1016/j.ceramint.2018.03.056. 
[21] N. Prompt, E. Ouedraogo, High temperature mechanical characterisation of an alumina refractory concrete for Blast Furnace main trough. Part I. General context, J. Eur. Ceram. Soc. 28 (2008) 2859-2865. doi:10.1016/j.jeurceramsoc.2008.04.031.

[22] E. Ouedraogo, N. Prompt, High-temperature mechanical characterisation of an alumina refractory concrete for Blast Furnace main trough PART II . Material behaviour, 28 (2008) 2867-2875. doi:10.1016/j.jeurceramsoc.2008.04.027.

[23] M. Kakroudi, M. Huger, C. Gault, T. Chotard, Damage evaluation of two alumina refractory castables, J. Eur. Ceram. Soc. 29 (2009) 2211-2218. doi:10.1016/j.jeurceramsoc.2008.12.019.

[24] T.M. Souza, A.P. Luz, M.A.M. Brito, V.C. Pandolfelli, In situ elastic modulus evaluation of $\mathrm{Al} 2 \mathrm{O} 3-\mathrm{MgO}$ refractory castables, Ceram. Int. 40 (2014) 1699-1707. doi:10.1016/j.ceramint.2013.07.066.

[25] S. Ribeiro, J.A. Rodrigues, The influence of microstructure on the maximum load and fracture energy of refractory castables, Ceram. Int. 36 (2010) 263 274. doi:10.1016/j.ceramint.2009.07.033.

[26] A.N. C. Parr, F. Simonin, B. Touzo, C.Wöhrmeyer, B. Valdelièvre, The impact of calcium aluminate cement hydration upon the properties of refractory castables, TARJ Meet. 33 (2004) 1-17. http://secar.ru/documents/TP_GB_RE_LAF_043.pdf.

[27] B. Touzo, F. Simonin, C. Wöhrmeyer, C. Parr, Microstructural Changes in Calcium Aluminates Cement Bonded Castable Systems, Tech. Pap. (Unitecr 2005). 33 (2005) 1-10.

[28] R.R. Lourenço, C.C.D. Exposito, R.S. Angélica, J. a Rodrigues, Sonochemical action and the influence of heat treatment conditions on the preparation of cements of the $\mathrm{CaO}-\mathrm{Al} 2 \mathrm{O} 3$ binary system, Cerâmica. 56 (2010) 28-38. doi:10.1590/S0366-69132010000100006.

[29] M. Nematzadeh, J. Dashti, B. Ganjavi, Optimizing compressive behavior of concrete containing fine recycled refractory brick aggregate together with calcium aluminate cement and polyvinyl alcohol fibers exposed to acidic environment, Constr. Build. Mater. 164 (2018) 837-849. doi:10.1016/j.conbuildmat.2017.12.230.

[30] C. Wöhrmeyer, C. Parr, H. Fryda, E. Frier, Calcium Aluminate Aggregates for use in Refractory Castables, 35th Am. Ceram. Soc. Symp. St. Louis, Missouri, USA, March 1999. 33 (2011) 1-13.

[31] N. Obradovic, A. Terzic, L. Pavlovic, S. Filipovic, V. Pavlovic, Dehydration investigations of a refractory concrete using DTA method, J. Therm. Anal. Calorim. 110 (2012) 37-41. doi:10.1007/s10973-011-1880-3.

[32] J.M. Auvray, C. Gault, M. Huger, Microstructural changes and evolutions of elastic properties versus temperature of alumina and alumina-magnesia 
refractory castables, J. Eur. Ceram. Soc. 28 (2008) 1953-1960. doi:10.1016/j.jeurceramsoc.2008.02.012.

[33] V. Muñoz, A.G. Tomba Martinez, Thermomechanical behaviour of Al2O3$\mathrm{MgO}-\mathrm{C}$ refractories under non-oxidizing atmosphere, Ceram. Int. 41 (2015) 3438-3448. doi:10.1016/j.ceramint.2014.10.146.

[34] F. Soukal, P. Ptacek, J. Másilko, T. Opravil, J. Havlica, M. Drdlová, High temperature properties of MDF composite based on calcium aluminate cement and polyvinyl alcohol, J. Therm. Anal. Calorim. 115 (2014) 12451252. doi:10.1007/s10973-013-3481-9.

[35] I.D. Katsavou, M.K. Krokida, I.C. Ziomas, Determination of mechanical properties and thermal treatment behavior of alumina-based refractories, Ceram. Int. 38 (2012) 5747-5756. doi:10.1016/j.ceramint.2012.04.021.

[36] E. Ouedraogo, M. Roosefid, N. Prompt, C. Deteuf, Refractory concretes uniaxial compression behaviour under high temperature testing conditions, J. Eur. Ceram. Soc. 31 (2011) 2763-2774. doi:10.1016/j.jeurceramsoc.2011.07.017.

[37] A. Baradaran-nasiri, M. Nematzadeh, The effect of elevated temperatures on the mechanical properties of concrete with fine recycled refractory brick aggregate and aluminate cement, Constr. Build. Mater. 147 (2017) 865-875. doi:10.1016/j.conbuildmat.2017.04.138.

[38] J. Fruhstorfer, C.G. Aneziris, In fl uence of particle size distributions on the density and density gradients in uniaxial compacts, Ceram. Int. 43 (2017) 13175-13184. doi:10.1016/j.ceramint.2017.07.011. 


\section{Artigo B Numerical modeling of the thermo-mechanical behavior of refractory concrete lining}

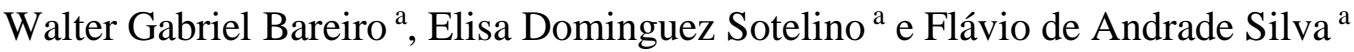

${ }^{a}$ Departamento de Engenharia Civil, Pontifícia Universidade Católica do Rio de Janeiro, (PUC-Rio), Rua Marquês de São Vicente 225, 22451-900, Gávea, Rio de Janeiro - RJ, Brazil.

November, 2018 


\begin{abstract}
Refractory concretes are widely applied for the lining of steel shell of industrial structures subjected to high temperatures and pressure. Working linings of steel ladles are made of high alumina concretes, i.e., as the first layers that receive the heat flow. Modeling the thermo-mechanical behavior of these layers under service conditions is of paramount importance to evaluate the failure or cracking that determine the useful life of these materials. In this work, simulations of the heating and holding process of linings composed of several layers of different types of refractory with different alumina contents (51wt\%, 71wt\% and 90wt\%), previously studied, were performed. The developed model employed axisymmetric finite elements and the thermo-mechanical analyses were carried out using the ABAQUS software package. The analyses considered transient heat flow. The simulations of the lining heating process were carried out for different combinations of the positioning of the layers made of different refractory concretes. The results of the thermo-mechanical response were compared and it was observed that the combination used the refractory concrete with $90 \mathrm{wt} \%$ of alumina as an inner layer, combined with materials of $71 \mathrm{wt} . \%$ and $51 \mathrm{wt} . \%$ as the middle and outer layers, respectively, is more efficient in terms of the thermal gradient. Therefore, would potentially lead to minor damage to the lining throughout the process of use. This indicates the importance of selection of the coating materials for application in layers. In addition, the simulations showed that this combination presented smaller areas prone to cracking.
\end{abstract}

Keywords: lining, refractory concrete, cylinders structures, numerical analysis, axisymmetric, layers, thermo-mechanical behavior, transient heat. 


\section{Introduction}

Refractory linings are widely used in various industries such as metallurgy, petrochemical, building materials, etc., mainly in cylindrical shells structures of production subjected to high temperature and with confining fluids under pressure (steelmaking ladles, gasifier, furnaces, vessels). Refractory linings determine the life of these applications [1-3]. That is, damage to refractory materials can affect the normal operation of the entire production process [4]. The damage mechanisms of the refractory concretes linings arise due to two causes: chemical erosion and thermo-mechanical stress $[5,6]$. The damage is caused by the thermal stress generated by thermal expansion and chemical reaction and it is the main reason for cracking failure of the lining $[7,8]$. Therefore it is necessary to analyze the distribution of temperatures and thermal stresses generated in the refractory lining during the heating process $[1,9]$.

In modern industries the use of new materials, such as functionally graded materials, are increasing because they can be designed to better control the stresses due to thermal and mechanical loads [10-12]. Conventional industrial components that use a single layer of lining material can often comply with the service requirements under high temperature, high fluid pressure and corrosive environment. Therefore, a multilayer pressure vessel are recommended to meet the requirement under different industrial service conditions $[9,12]$. That is, using different layers of different materials. Generally, the inner layer is composed of alloy materials high mechanical and refractory performance, because the inner layer is subjected to high fluidity of pressure and high temperature. While the outer layer is made of steel or fiber. Being all layers are firmly bonded together [13]. 
The study of thermo-mechanical behavior and material design of functionally graded materials (FGM) have attracted considerable attention in recent years in the field of structural ceramic applications $[12,14,15]$. FGM is a type of composite material in which physical and mechanical properties of the material vary spatially along specific directions to achieve specific thermal and/or mechanical properties for some specific applications [15]. Therefore, to analyze the thermomechanical behavior of these applications, the simulations under operating conditions have a great practical contribution.

The focus of this work is thick-walled cylindrical pressure vessels, since they have a wide spectrum of applications in various industries because they are capable of confining fluids under pressure. The classical Lame's theory of thick walled cylinders [16] states that if the internal fluid pressure approaches the safe working stress limit of the material, the cylinder will burst. To overcome this problem, the use of compound cylinders made from two or more cylinders is recommended.

Some researches on the mechanical behavior of compound cylinders are found in the literature. Shi et al. [17] for example, presented an analytical linear elastic model to calculate the stress distribution in pressurized vessels made of multilayer materials.

In industry these compound cylinders are used to withstand thermal loads and mechanical loads. The thermal loads generate an internal stress distribution highly influenced by the temperature variation through the thickness of multilayer cylinder The difference between the coefficients of thermal expansion of the materials of the layers also influence the distribution of thermal stresses. Zhang et al. [18] also proposed an analytical solution to determine the stress distribution in a multilayered compound vessels submitted to thermal load and internal pressure, but the 
difference was to consider the cylinders with closed ends. The proposed analytical solution can be used to design multilayered composite pressure vessels.

The materials denominated as FGM have been investigated for their wide applications. Jabbari et al. [19] presented an analytical solution for the calculation of thermal and mechanical stresses due to steady state axisymmetric loads in thick hollow cylinder, using Navier's equations. The proposed method can be applied for simple mathematical functions and also for complex boundary conditions. Recently Vedeld et al. [20] obtained an analytical expression for the field of displacement and state of tension in cylinders of two layers subjected to pressure, thermal load and also axially loaded.

Shao et al. [21] considered the thermal and mechanical axisymmetric loads applied in a transient manner. Using Laplace's transform and series solving method for ordinary differential equation, they obtained solutions for the time-dependent temperature and thermo-mechanical stresses. Moreover, the transient response of a quasi-static coupled thermo-elastic problem for hollow cylinders under different boundary conditions was also studied in other works [22,23]. The study of compound cylinders subjected to internal heat flow and / or internal pressure is an approach of practical interest. The various industrial applications that use this system of layered materials leads to the search for greater optimization of these materials from the point of view of maintaining the internal heat of the units and maintenance of operation. This leads to the analysis of the thermomechanical behavior of the set of materials. However, most of the work involves only analyzes of the thermal stresses of cylinder compounds obtained at steady state. [12,20,23].

In the present work, the thermomechanical response of refractory linings to a service load typical for a cylinder ladle has been studied by means of FEM 
simulations. The main types of thermo-mechanical loading have been considered. The first is the one that occurs during the initial heating-up of a cold lining to predict the temperature distribution and thermal stresses ladle. The second is during the fluid holding process. The results of finite element model were validated with the analytical solutions provided in the literature for the same boundary conditions.

\section{Problem Definition}

This work considers a refractory lining system composed of alumina-based refractory concretes used as the working layer of an industrial thermal installation. As mentioned previously, the working layer is the one that receives heat directly by convection of the fluid inside the vessel [24]. These vessels are designed to hold up to $100 \mathrm{t}$ of liquid iron. In this study, a generic industrial unit vessel, based on the steelmaking ladle, was considered for the investigation of the proposed lining system.

The studied linings were composed of three layers of refractory alumina concrete A51, A71 and A90. The amounts of alumina were 51wt.\%, 71 wt.\% and 90 wt.\% respectively. The physical, chemical and mechanical properties at different temperatures of these refractory concretes were studied in a previous research [2527]. The results obtained are summarized in Table 1.

For the cylindrical vessel with typical geometrical dimensions were modeled and FE simulations were carried out. The developed FE model had $3.5 \mathrm{~m}$ of the inner diameter and each layer of refractory concrete was $0.10 \mathrm{~m}$ thick and the steel shell $0.0127 \mathrm{~m}$ thick [28-30]. Figure 1 shows the details of the system modeled. In actual applications, the cylinder length $(\mathrm{L})$ is much larger than the other dimensions. Figure 1 illustrates one of the different combinations of layers used for the 
simulations (A51 | A71 | A90). The positions of the different refractories in the multilayer system were varied in order to determine the combination with the best performance.

The heat flux between inside of the cylinder and the outside was modeled using the standard heating curve used in industrial applications and recommended by suppliers of refractory materials in the steel industry [31,32]. In the next section, the details of the developed finite element model for the investigation of the thermomechanical behavior of the lining during heating are discussed in detail.

Table 1 - Properties of refractory concretes and steel

\begin{tabular}{|c|c|c|c|c|c|}
\hline \multirow[t]{2}{*}{ Properties } & \multirow[t]{2}{*}{ Temperature } & \multicolumn{3}{|c|}{ Refractory Concrete Types } & \multirow[t]{2}{*}{ Steel } \\
\hline & & A51 & A71 & A90 & \\
\hline \multirow[t]{6}{*}{ Elastic Modulus (GPa) } & $25^{\circ} \mathrm{C}$ & 21.00 & 5.10 & 2.60 & 210 \\
\hline & $150^{\circ} \mathrm{C}$ & 5.56 & 3.50 & 3.00 & 210 \\
\hline & $300^{\circ} \mathrm{C}$ & 3.25 & 1.75 & 2.50 & 210 \\
\hline & $600^{\circ} \mathrm{C}$ & 3.06 & 1.31 & 4.10 & 160 \\
\hline & $1000^{\circ} \mathrm{C}$ & 1.60 & 1.06 & 1.30 & 160 \\
\hline & $1200^{\circ} \mathrm{C}$ & 3.45 & 1.50 & 1.50 & 160 \\
\hline \multirow{6}{*}{$\begin{array}{l}\text { Compressive Strength } \\
(\mathrm{MPa})\end{array}$} & $25^{\circ} \mathrm{C}$ & 63.00 & 59.00 & 17.00 & 500 \\
\hline & $150^{\circ} \mathrm{C}$ & 53.50 & 40.40 & 18.50 & - \\
\hline & $300^{\circ} \mathrm{C}$ & 35.00 & 27.50 & 22.60 & - \\
\hline & $600^{\circ} \mathrm{C}$ & 25.60 & 21.50 & 23.00 & - \\
\hline & $1000^{\circ} \mathrm{C}$ & 15.70 & 12.60 & 14.00 & - \\
\hline & $1200^{\circ} \mathrm{C}$ & 41.00 & 21.65 & 19.75 & - \\
\hline \multirow{6}{*}{$\begin{array}{l}\text { Thermal conductivity } \\
\text { coefficient }\left(\mathrm{W} \cdot \mathrm{m}^{-1} \cdot \mathrm{K}^{-1}\right)\end{array}$} & $25^{\circ} \mathrm{C}$ & 1.25 & 2.18 & 2.68 & 54 \\
\hline & $150^{\circ} \mathrm{C}$ & 1.22 & 2.32 & 2.88 & 54 \\
\hline & $300^{\circ} \mathrm{C}$ & 1.18 & 2.11 & 2.61 & 42 \\
\hline & $600^{\circ} \mathrm{C}$ & 1.12 & 2.04 & 2.40 & 42 \\
\hline & $1000^{\circ} \mathrm{C}$ & 1.10 & 2.50 & 3.15 & 31 \\
\hline & $1200^{\circ} \mathrm{C}$ & 1.48 & 1.96 & 2.25 & 31 \\
\hline \multirow{3}{*}{$\begin{array}{c}\text { Thermal expansion } \\
\text { coefficient }\left(K^{-1}\right)\end{array}$} & $25^{\circ} \mathrm{C}$ & $7 \times 10^{-6}$ & $7 \times 10^{-6}$ & $7 \times 10^{-6}$ & $1.1 \times 10^{-5}$ \\
\hline & $600^{\circ} \mathrm{C}$ & $7.2 \times 10^{-6}$ & $7.2 \times 10^{-6}$ & $7.2 \times 10^{-6}$ & $1.3 \times 10^{-5}$ \\
\hline & $1200^{\circ} \mathrm{C}$ & $9 \times 10^{-6}$ & $9 \times 10^{-6}$ & $9 \times 10^{-6}$ & $1.3 \times 10^{-5}$ \\
\hline Poisson's ratio & $25-1200^{\circ} \mathrm{C}$ & 0.20 & 0.20 & 0.20 & 0.30 \\
\hline Heat capacity $\left(J . \mathrm{kg}^{-1} \mathrm{~K}^{-1}\right)$ & $25-1200^{\circ} \mathrm{C}$ & 980 & 980 & 980 & 460 \\
\hline Density (kg.m ${ }^{-3}$ ) & $25-1200^{\circ} \mathrm{C}$ & 3.020 & 2860 & 2700 & 7800 \\
\hline
\end{tabular}




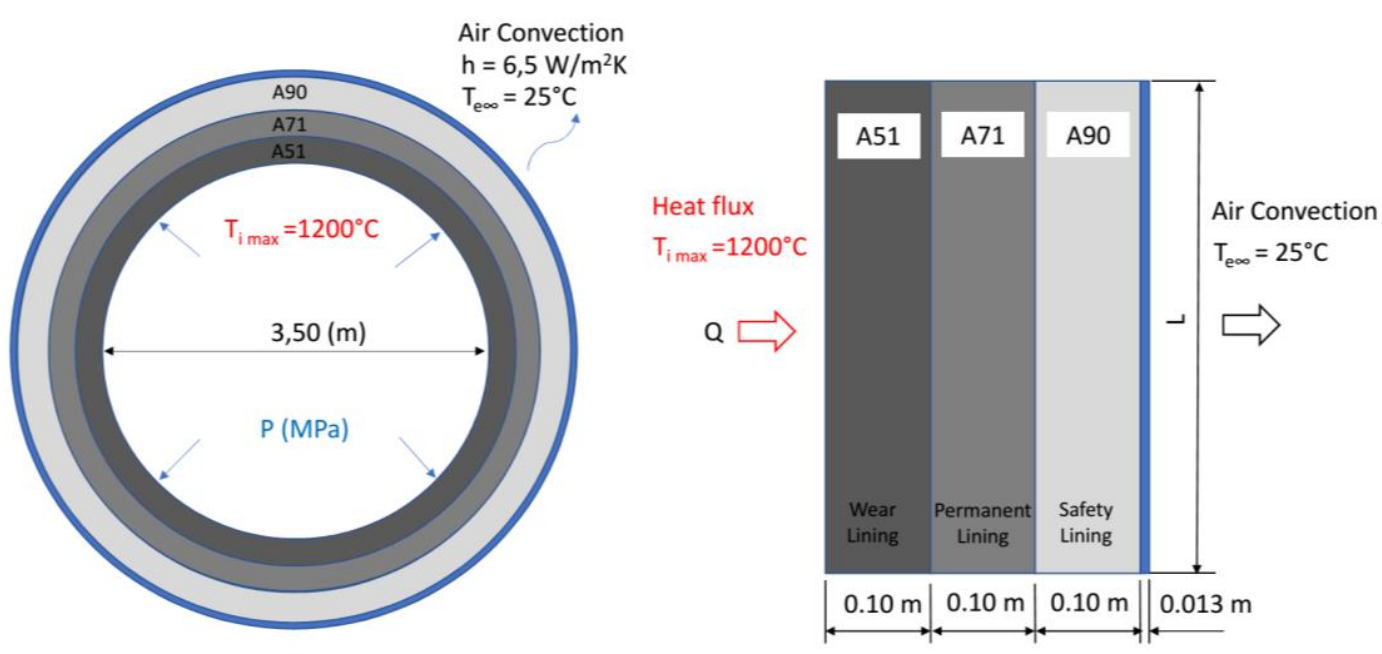

Figure 1 - Materials and geometry composing the lining system

\section{The finite element model}

Thermo-mechanical coupling finite element model of the cylindrical vessel with a multilayered lining subjected to thermal load and internal pressure was developed. The axisymmetric nature of the geometry, thermal loading and material properties were explored resulting in an axisymmetric model that was used to study the effects of the temperature increase and the existing internal pressure caused by the fluid. The mechanical constituent model considered was the thermo-elasticity model. The selected finite element type was the CAX8RT in ABAQUS, which is a 8-node quadratic element and uses reduced integration. The convergence of the model was studied by subsequent refinement of the finite element mesh and it was determined that a mesh consisting of 3100 axisymmetric elements of $0.010 \mathrm{~m}$ converged within a tolerance of $5 \%$, which was considered adequate for this study. Figure 2 illustrates the finite element mesh used for the simulations. It also shows the four different combinations of the different positioning of the three refractory layers in this work. 

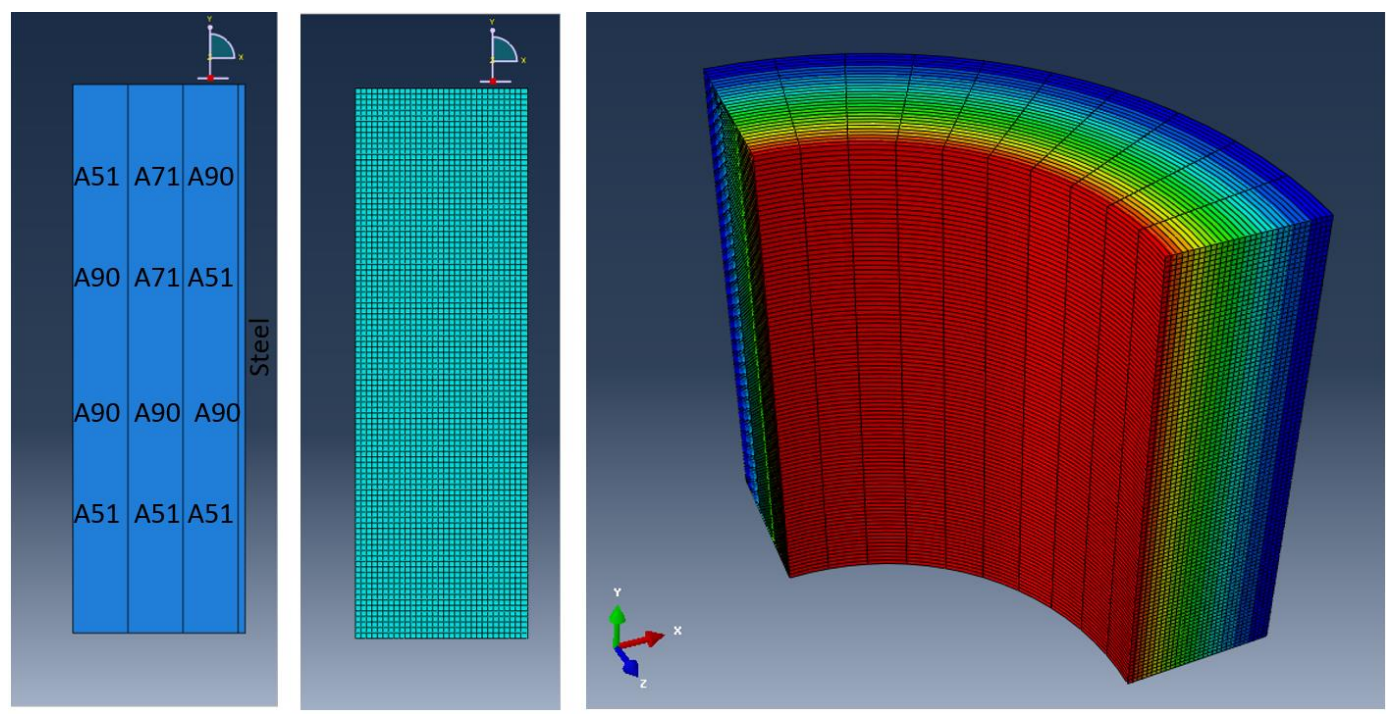

Figure 2 - Axisymmetric model of refractory lining

In this model, the refractory materials were assumed homogeneous and isotropic and the interface between layers was assumed to be perfectly bonded. The mechanical properties (modulus of elasticity and compressive strength) of each refractory concretes at different temperatures were obtained in a previousexperimental study [25]. Although the evaluation of these mechanical behavior was residual was adopted here for the condition of temperature evolution as an approximation of the study. . The system is confined in the cylinder, this was considered in the modeling through the application of steel shell layer.

The simulations consisted of two successive executions of the model. In the first step, the heating process was simulated, temperature profiles are obtained and consequently the thermal stresses generated. In the following step the fluid pressure was applied at the end of the heating process.

The thermal boundary conditions (up to $1200^{\circ} \mathrm{C}$ ) were applied to the inner surface of the cylinder model. The temperatures were established based on the standard heating schedule (Table 2) used in industrial applications and 
recommended by suppliers of refractory materials in the steel industry. The heating regime was included in the form of steps for each ramp and level in the ABAQUS program. This heating curve was tested and evaluated in simulations performed by Pereira et al. [31]. Homogeneous heat transfer was assumed on the overall internal surface of the lining. The heat transfer between the steel shell and the environment was simulated by a thermal convection flux. The thermal convection coefficient value $\mathrm{h}=6.5 \mathrm{Wm}^{-2} \mathrm{~K}^{-1}$ was adopted from in situ measurements in steel facilities as reported by Carvalho et al. [33].

Table 2 - Temperature at the internal surface of the lining as a function of time

\begin{tabular}{cccccc}
\hline Time & $\mathbf{0 h - 8 h}$ & $\mathbf{8 h - 2 0 h}$ & $\mathbf{2 0 h - 4 0 h}$ & $\mathbf{4 0 h - 5 0 h}$ & $\mathbf{5 0 h - 7 2 h}$ \\
\hline Temperature & $25-200^{\circ} \mathrm{C}$ & $200^{\circ} \mathrm{C}$ & $200-600^{\circ} \mathrm{C}$ & $600^{\circ} \mathrm{C}$ & $600-1200^{\circ} \mathrm{C}$ \\
\hline Heating rate & $20^{\circ} \mathrm{C} / \mathrm{h}$ & - & $20^{\circ} \mathrm{C} / \mathrm{h}$ & - & $30^{\circ} \mathrm{C} / \mathrm{h}$ \\
\hline
\end{tabular}

Since the pressure ladle is free to expand and is subjected to an internal fluid pressure $(p)$ and to an internal thermal load $\left(T_{i}\right)$, the boundary conditions were set as follows:

$$
\begin{array}{cc}
\sigma_{r}(r)=-p & \text { when } r=R_{i} \\
\sigma_{r}(r)=0 & \text { when } r=R_{o} \\
T(r)=T_{i} & \text { when } r=R i \\
T(r)=T_{O} & \text { when } r=R_{o}
\end{array}
$$

where $T_{i}$ and $T_{o}$ are the uniform temperatures at the inner and outer surfaces, respectively, $r$ is the radial distance, and $R_{i}$ and $R_{o}$ are the radial distances to the inner and outer surfaces, respectively.

The mechanical boundary conditions were established at the bottom and top edges of the cylinder on all layers. The displacements in the axial direction $\left(U_{z}\right)$ and in the radial direction $\left(U_{x}\right)$ were set to zero at the edges. 


\section{Analytical model of the thermo-mechanical stresses in layered cylinder}

The finite element model was validated by comparing the results with those obtained by analytical solutions encountered in the literature for a multilayer hollow cylinder subjected to thermomechanical load $[18,20,22]$. The analytical model provides the transient thermal response of the cylinder, which is assumed to be long enough in the axial direction so that plane strain condition holds, i.e., the axial strain is zero $\left(\varepsilon_{z}=0\right)$.

Since the problem is axisymmetric, the temperature distribution depends only on the radial position, $r$. In the steady state, the heat flux, $Q$, is conserved across different layers of the cylinder and is given by Equation (1). In the Figure 3 the variables of the equation for a cylinder with two layers are indicated.

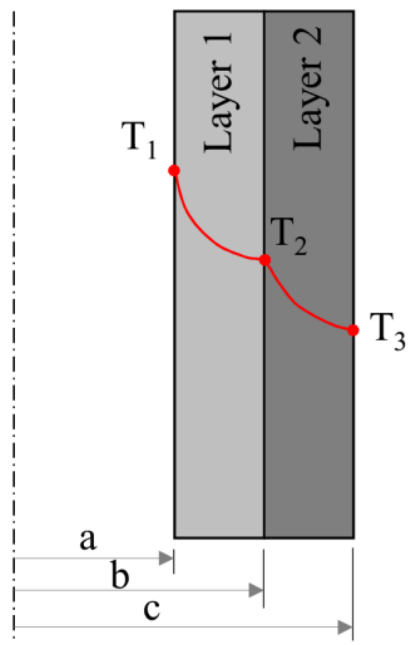

Figure 3 - Variables of cylinder composed by layers

$$
Q=\frac{2 \pi k_{1} L\left(T_{1}-T_{2}\right)}{\ln (b / a)}=\frac{2 \pi k_{2} L\left(T_{2}-T_{3}\right)}{\ln (c / b)}
$$


where $k_{1}, k_{2}$, is the thermal conductivity of cylinder 1 and cylinder 2 , respectively, $L$ is the length of the two cylinders, $T_{1}$ is the temperature in contact with the inner cylinder, $T_{2}$ is the temperature of the contact surface between the layer 1 and layer $2, T_{3}$ is the ambient temperature at the outer surface of cylinder and $a, b, c$ are the compound cylinder radius.

Equation (2) gives the radial temperature variations for the cylinder Cyi ( $\mathrm{i}=$ 1,2, , which follows a logarithmic form, in the inner or the outer cylinders [20].

$$
T_{c y}(r)=\left(T_{i n}-T_{o u}\right) \frac{\ln \left(\frac{r_{o u}}{r}\right)}{\ln \left(\frac{r_{o u}}{r_{i n}}\right)}+T_{o u}
$$

$T_{i n}, T_{o u}, r_{i n}$ and $r_{o u}$ are respectively the inner and outer temperature and radius of the cylinder.

A generalized analytical solution for a multilayered composite pressure cylinder both fluid pressure and thermal load is derived based on the following assumptions [18]:

(i) The materials of the layers are homogeneous and isotropic.

(ii) All layers of the multilayered pressure vessels are perfectly bonded.

(iii) The deformation satisfies Hooke's law and small strain theory.

(iv) All physical variables are those of an axisymmetrical problem.

(v) Steady-state heat conduction for thermoelastic problem.

(vi) The axial strain is uniform within each layer.

Using the plane strain assumption (iii) and axisymmetry (iv), the strain displacement follows the below equations, the equilibrium Equation (3) and the strain-displacement relationship for a long cylinder Equation (4) are written as:

$$
\frac{d \sigma_{r}}{d r}+\frac{\sigma_{r}-\sigma_{\theta}}{r}=0
$$




$$
\varepsilon_{r}=\frac{d u}{d r}, \quad \varepsilon_{\theta}=\frac{u}{r}, \quad \varepsilon_{z}=0
$$

With assumption (v), then Eq. (3) is solved and stress distribution is found. The stress-strain relations in a axisymmetric pressure can be written Equation (57), according to Reference [18], are.

$$
\begin{aligned}
& \sigma_{r}=\frac{E}{(1+v)(1-2 v)}\left[(1-v) \varepsilon_{r}+v\left(\varepsilon_{\theta}+\varepsilon_{z}\right)\right]-\frac{E \alpha T(r)}{1-2 v} \\
& \sigma_{\theta}=\frac{E}{(1+v)(1-2 v)}\left[(1-v) \varepsilon_{\theta}+v\left(\varepsilon_{r}+\varepsilon_{z}\right)\right]-\frac{E \alpha T(r)}{1-2 v} \\
& \sigma_{z}=\frac{E}{(1+v)(1-2 v)}\left[(1-v) \varepsilon_{z}+v\left(\varepsilon_{\theta}+\varepsilon_{r}\right)\right]-\frac{E \alpha T(r)}{1-2 v}
\end{aligned}
$$

where $\sigma_{r}, \sigma_{q}$, and $\sigma_{z}$ are the radial, hoop and axial stresses, respectively. The radial displacement is $\mathrm{u}, \alpha$ denotes the coefficient of thermal expansion, $v$ denotes Poisson's ratio, and $E$ denotes Young's modulus. $\varepsilon_{r}, \varepsilon_{q}$, and $\varepsilon_{z}$ are the radial, hoop and axial stresses, respectively. $T$ denotes the temperature change from the reference temperature.

From Eqs. (4) and (5-7), the Eq. (3), becomes, in term of radial displacement u uq. $_{\mathrm{i}}$ (8):

$$
\frac{d}{d r}\left(\frac{1}{r} \frac{d u_{i}}{d_{r}}\right)=\left(\frac{1+v_{i}}{1-v_{i}}\right) \alpha \frac{d T_{i}}{d r}
$$

The integration of Equation (8) results in Equation (9).

$$
u_{i}(r)=\left(\frac{1+v_{i}}{1-v_{i}}\right)\left(\frac{\alpha_{i}}{r}\right) \int_{r_{i n}}^{r} r T_{i} d r+C_{i 1} r+\frac{C_{i 2}}{r}
$$


where $r$ is the radial position, $i$ designates the layer number and $C_{i 1}, C_{i 2}$ are the constants of integration for cylinder that depend on the number of layers and are determined using the boundary conditions in the compound cylinders.

\section{Results and Discussion}

The results from the simulations of the thermomechanical behavior of the refractory linings during the heating process are analyzed in this section. In particular, the thermal gradient and the stress distributions through the layers thickness are characterized. Different combinations of the positioning of the three refractory concretes in the lining layers were considered. The layer combinations analyzed were: | A51 | A71 | A90 |, | A90 | A71 | A51 |, | A51 | A51 | A51 | and | A90 | A90 | A90 |, being that the first assignment corresponds to the innermost layer, the second to the middle layer and the third the layer in contact with the steel. As mentioned previously, perfect bond was considered between layers.

In the following sections the different thermal gradients generated by the different layer combinations and their influence on the thermal stresses after the heating process will be analyzed. Besides that, the stress variations at different points of the coating are shown during the heating process. This is to analyze the critical points of failure. It was also considered the application of fluid pressure to the analyzes of thermo-mechanical behavior for the different combinations of lining.

\subsection{Influence of the combinations of the layers on the thermal gradient}

Figure 3 shows temperature gradients through the thickness of the layers for the different layers combinations of refractory concrete lining. The temperature 
profiles shown are those corresponding to the final step of the heating process, i.e., obtained immediately at $1200^{\circ} \mathrm{C}$. As can be seen, the more gradual temperature gradient was obtained for the $\mid$ A90 | A71 | A51 | combination, i.e. for the combination with the refractory concretes with $90 \mathrm{wt} \%$ as the inner layer, with $71 \mathrm{wt} \%$ as the middle layer and with $51 \mathrm{wt} . \%$ as the outer layer. The reverse combination | A51 | A71 | A90 |, showed the most pronounced gradient. For both cases the inclination of the gradient curve showed a discontinuity at the interface between the layers of different conductivities. This is significant for the stress distributions and when it is desired to achieve a given temperature on the outer surface. The other combinations with the three layers of the same refractory concrete | A51 | A51 | A51 | and | A90 | A90 | A90 | generated gradients that remained in an intermediate zone. Although the difference between the gradient of the entire lining of $\mid$ A51 $\mid$ A51 | A51 | with lining | A90 | A71 | A51 | is small, it should be noted that other important design factors may determine the use of the lining, such as the mechanical strength of refractories, erosion resistance, etc.

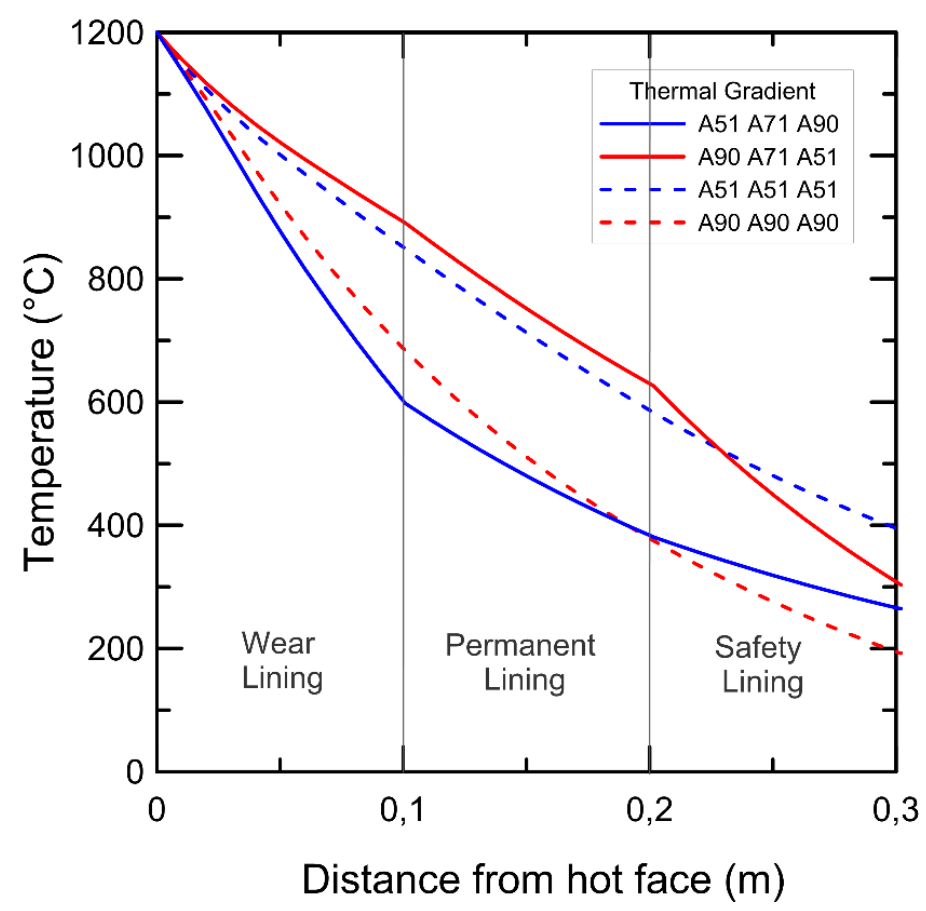

Figure 3-Thermal gradient resulting in different combinations of refractory layer. 
The different gradients obtained can be explained by the influence of the thermal conductivity coefficient of each material, since the higher the alumina content of the concrete the higher the thermal conductivity. Therefore, it can be concluded that the thermal conductivity $(k)$ is one of the most important properties for the design and optimization of refractory linings, as well as for defining safe heating schedules, which is confirmed by the findings in [1].

According to the literature [34], the more gradual gradients generate less damage to the material and generate lower thermal stress gradients in the lining layers, whereas more pronounced gradients generate higher thermal stresses. Therefore, refractory coatings that generate more gradual gradients are more efficient for thermo-mechanical performance. Almost all combinations tested in the present study reach a temperature within the recommended range on the steel contact surface $\left(200-300^{\circ} \mathrm{C}\right)$.

\subsection{Thermal and thermo-mechanical Stresses}

To evaluate the strength of the refractory linings, stresses and displacements distributions through the various thickness layers were obtained. As it will be seen, the mechanical properties of the different refractory concretes used for the threelayer lining influenced the results. It can be observed from the simulations that during the heating process, the thermal expansion of the refractory concrete causes displacements in the radial direction of the entire lining system as can be seen from Figure 4. These displacements are restricted by the outside steel shell layer causing the development of thermal stresses in the lining. Compressive stresses are 
generated in the region of high temperature (near the hot face) and tensile stresses in the regions of lower temperature (near the face subject to the room temperature) [35]. This indeed explains the deformed of the lining due to the thermal expansion obtained in the simulations for all combinations, i.e., as the ends were considered fixed, the lining bends causing the inner layer to under compression and the outer layer under tension (layer in contact with the steel liner).

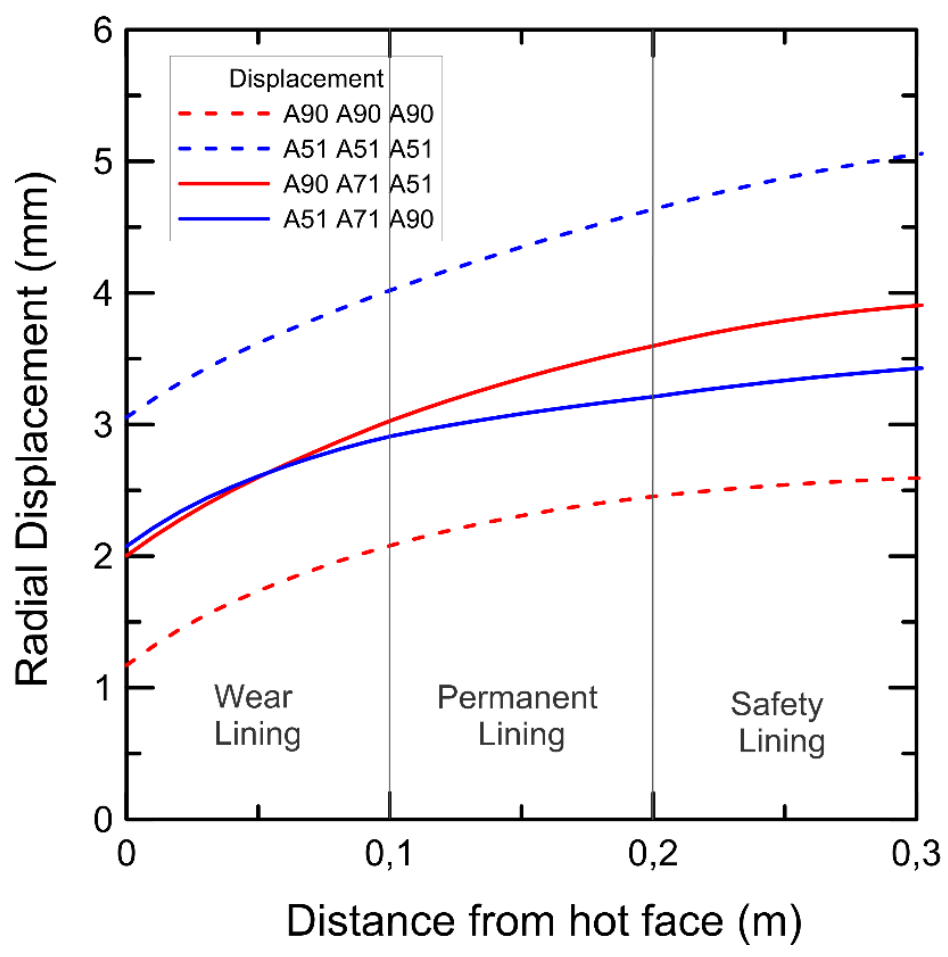

Figure 4 - Radial displacements vs thickness of refractory layers.

Expansion thermal stress is one of the most important factors for the occurrence of damage when linings work under high temperature conditions [29]. The values of the thermal stresses in the different directions generated in the simulations for the different combinations of layers after the heating process are shown in Figures 5 through Figure 7. In these Figures $\sigma_{r}, \sigma_{\theta}$ and $\sigma_{z}$ are the radial stress, hoop stress and axial stress, respectively. The variations of the stresses in the compressive radial direction $\left(\sigma_{r}\right)$ in the layers (Figure 5) are generated over the 
entire thickness of the refractory lining system. The maximum peaks of compressive stress occur for the layer combinations that had the A51 refractory concrete as the innermost layer, and the smaller peaks of compressive stress in the combinations that had A90 as the inner layer. In all layer combinations the peak compressive radial stress occurs in the middle layer (permanent layer). The effect of the thermo-mechanical characteristics of the lining materials can be seen clearly on the radial stress distribution.

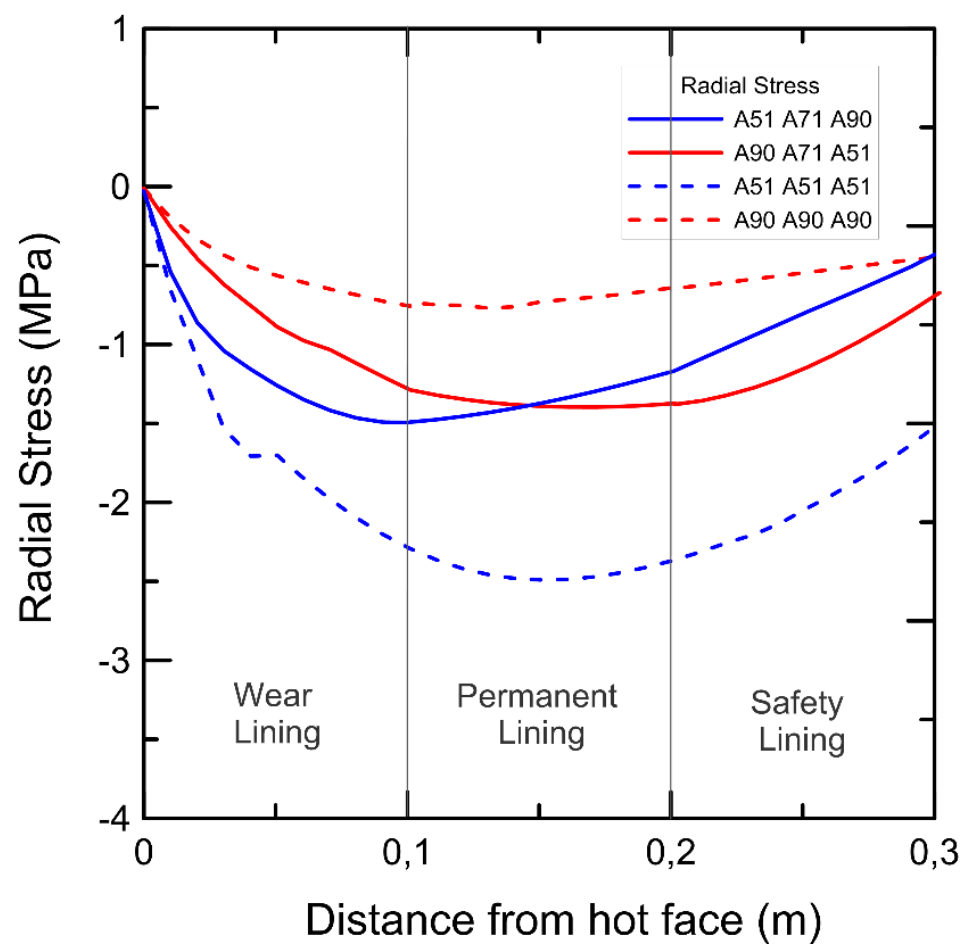

Figure 5 - Radial stress distribution in refractory layers

Figure 6 shows the variations of the stresses in the hoop direction $\left(\sigma_{\theta}\right)$ through the lining system thickness at the end of the heating process $\left(1200^{\circ} \mathrm{C}\right)$. As can be seen jumps in stresses occur at the interfaces between the different refractory concrete layers. The maximum value of compressive stress occurs at the innermost surface of the lining. It can also be observed that the hoop stress values are 
significantly higher than those of the radial stresses. As can be seen there is little variation of the stresses in the middle layer (permanent lining) when different refractories are adopted in each layer. It is also noted that the maximum compression values obtained in the inner layer were close to the strength limit (see Table 1) of the refractory concretes used.

Figure 7 shows the distribution of axial stresses $\left(\sigma_{z}\right)$ through the layers of the lining system. The curves are similar to those obtained for the hoop stress $\left(\sigma_{\theta}\right)$. However, the jumps are smaller at the interfaces between the different layers.

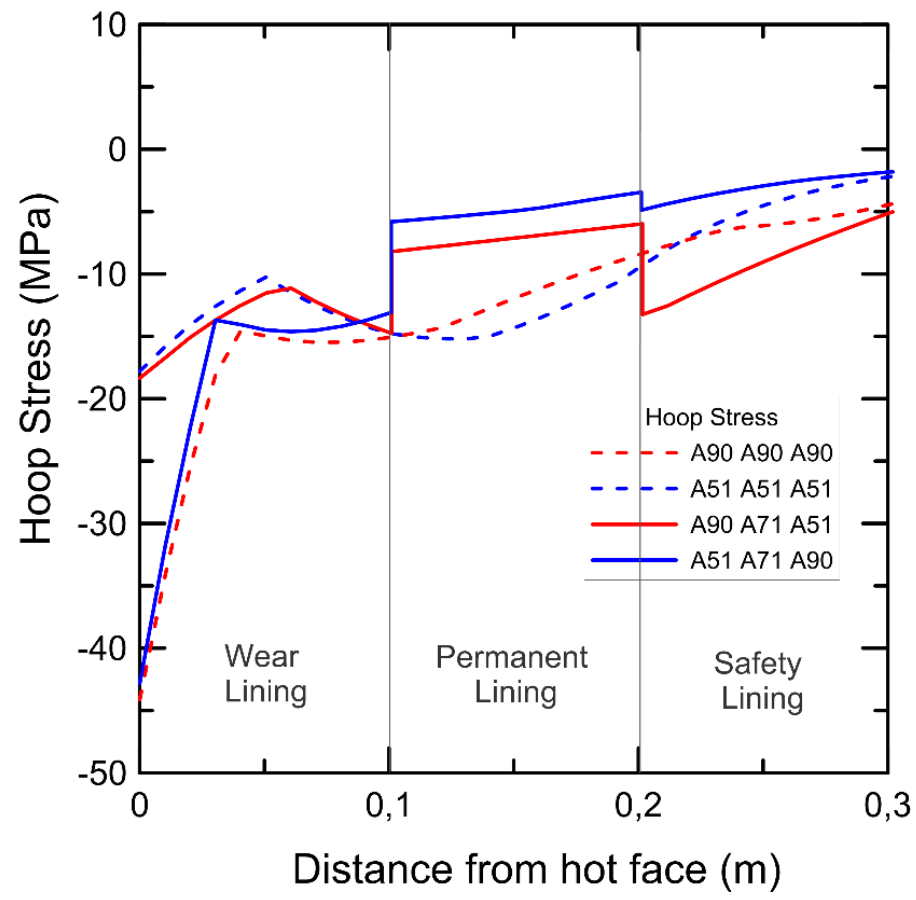

Figure 6 - Hoop stress distribution in refractory layers 


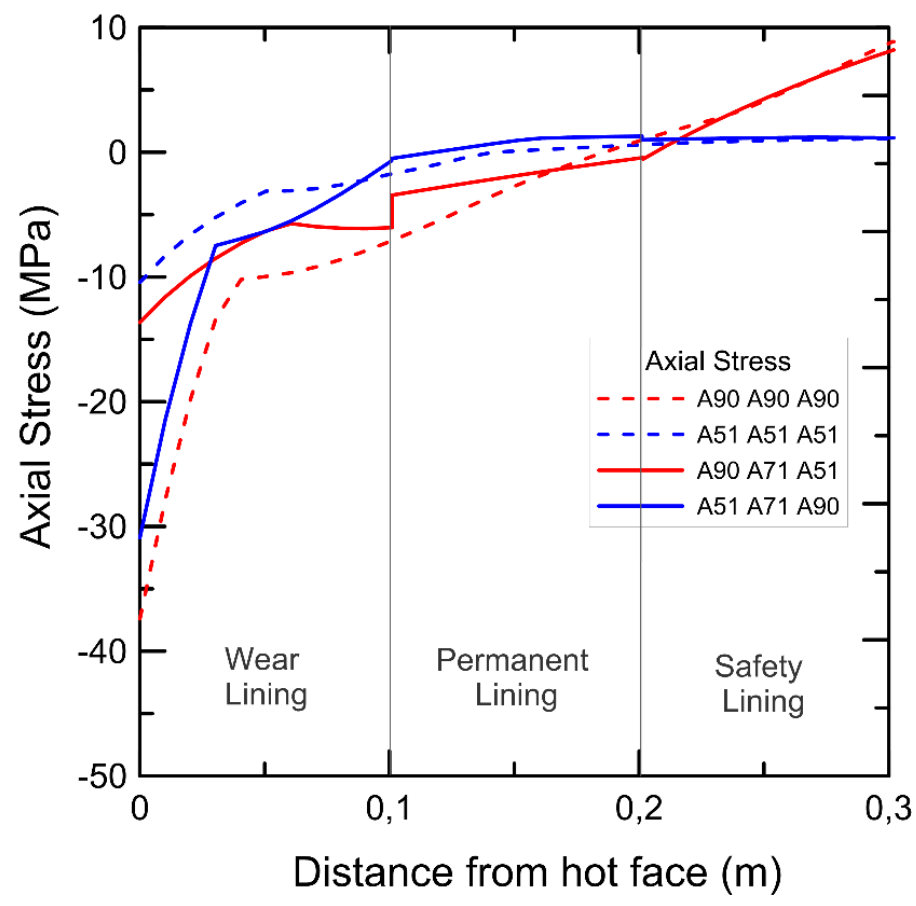

Figure 7 - Axial stress distribution in refractory layers

The thermo-mechanical stresses in the lining system due to an internal pressure (20MPa) after the heating process were also obtained. The internal temperature was kept at $1200^{\circ} \mathrm{C}$. The results are presented in Figure 8 e Figure 9, for the radial and hoop stresses, respectively.

In the simulations in transient condition, it can be noted that by passing time, the temperature distribution tends to a linear form and after a long time it is considered as a steady state. This behavior is reasonable because they were considered isotropic materials [36]. Therefore, the simulations of the pressure retention process, where the temperature was maintained at $1200{ }^{\circ} \mathrm{C}$ for a long time, were performed at steady state. Then, the results obtained in the simulations were validated with the analytical solutions of Zhang et. al. [18].

The effect of the internal pressure on the lining stresses is lower for combinations as the inner layer with A90 refractory than for layers A51. The radial 
stresses are more affected by the application of internal pressure than the hoop stresses.

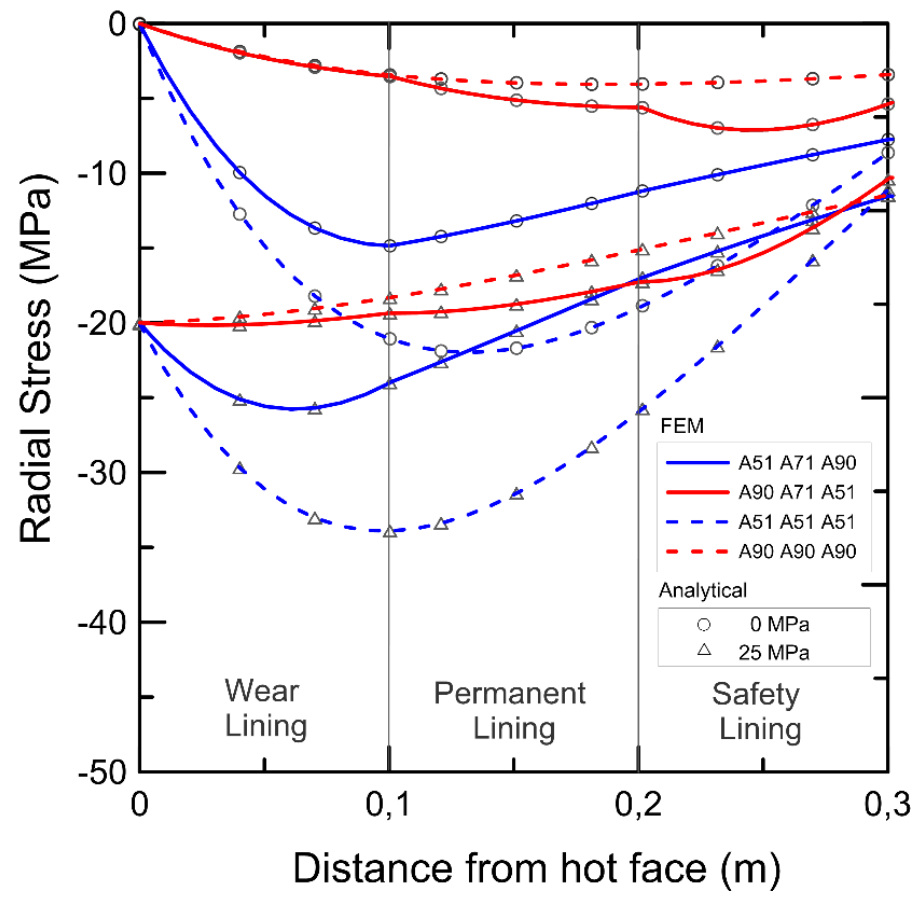

Figure 8 - Internal pressure effect on radial stress

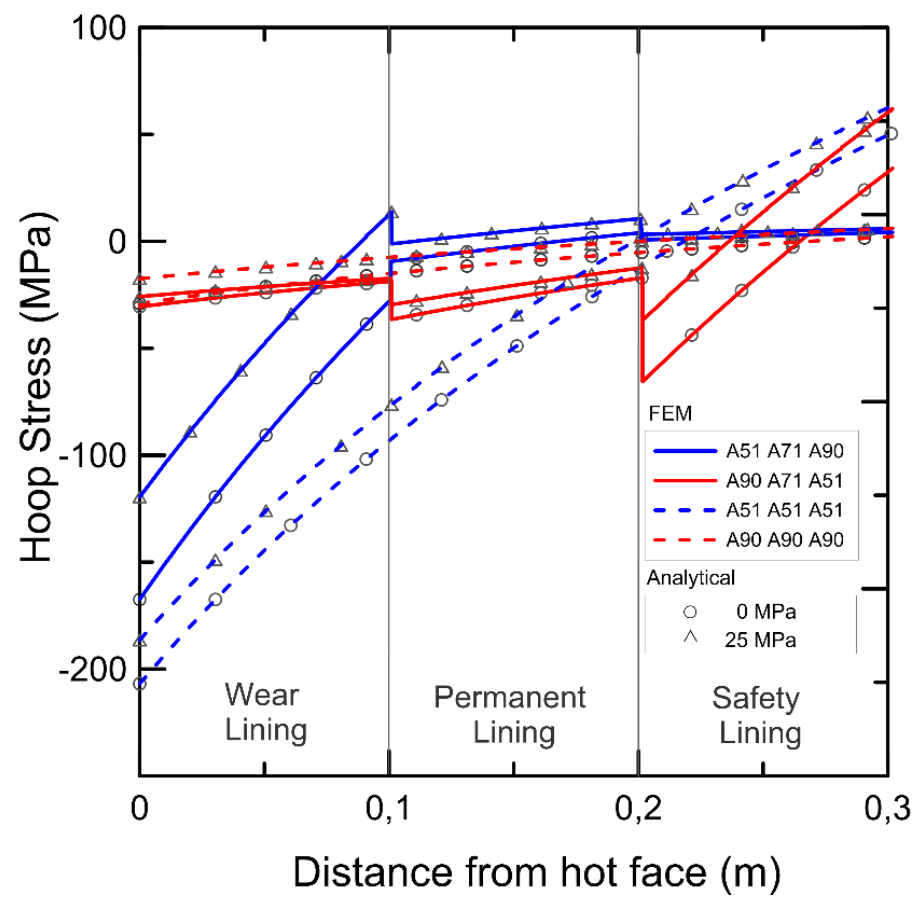

Figure 9 - Internal pressure effect on hoop stress 


\subsection{Simulation of the thermal stresses during heating process}

The variations of the thermal stresses in the hoop direction during the heating time at different points in the lining are shown in Figure 10. The changes in the curves indicate that the maximum compression stresses in the circumferential direction considered at a node P1 of the inner surface layer 1 (hot surface), also shown schematically in the figure, were generated at the end of the heating process, as shown in Figure 10a. The compressive stress values obtained were below the compressive strength limit of the refractory concretes tested. Point $\mathrm{P}_{2}$ in the layer 2, shown schematically in Figure 10b is also subjected to compressive stresses throughout the heating time, however very little variation of stresses is observed.

The maximum tensile stresses measured at node $\mathrm{P}_{3}$ of the outer surface layer 3, shown schematically in Figure 10c, were generated between 36 and 40 hours of heating for the combinations | A90 | A71 | A51 | and | A51 | A51 | A51 |. However, for the combinations of layers | A51 | A71 | A90 | and | A90 | A90 | A90 |, the maximum tensile stresses occurred at $12 \mathrm{~h}$ and $24 \mathrm{~h}$ of heating time, respectively. At the end of the heating (70h) the combinations $\mid$ A90 |A71 | A51 | and | A51 |A51 | A51 | of layers showed tensile stresses greater than the tensile strength of the refractory materials, $8 \%$ higher than the nominal strength value. In this condition the lining could fail by cracking. One solution to this problem would be the use of refractory concretes reinforced with stainless steel fibers to improve the thermomechanical behavior. 
a)

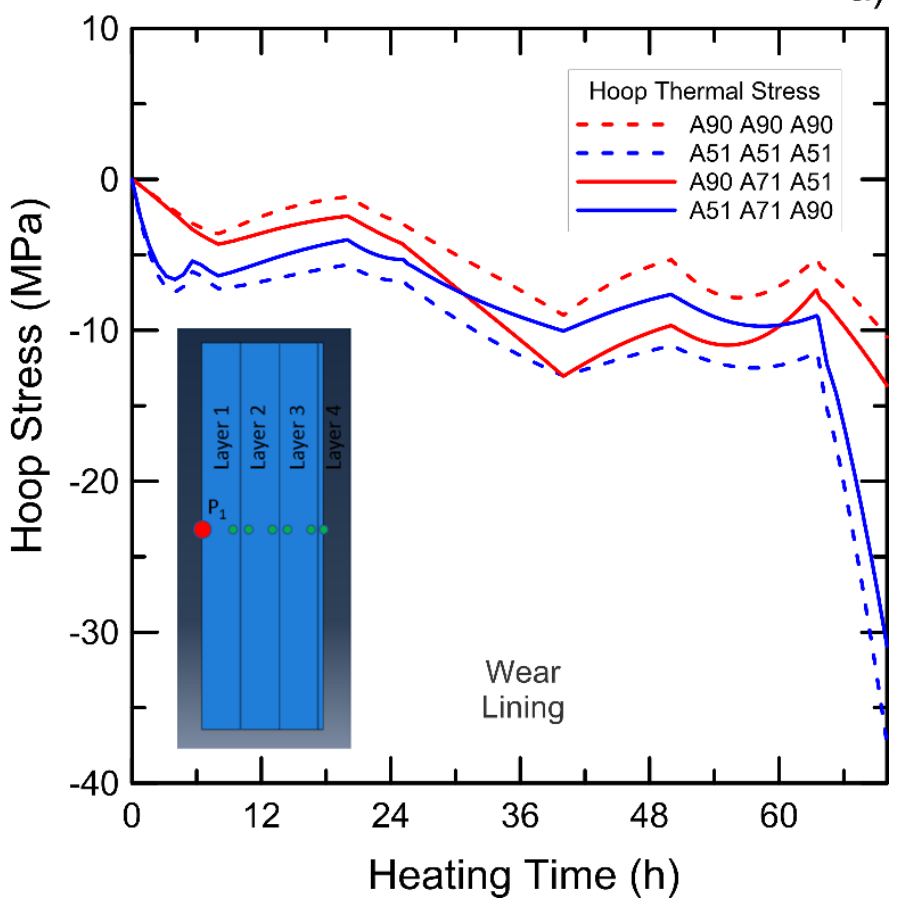

b)

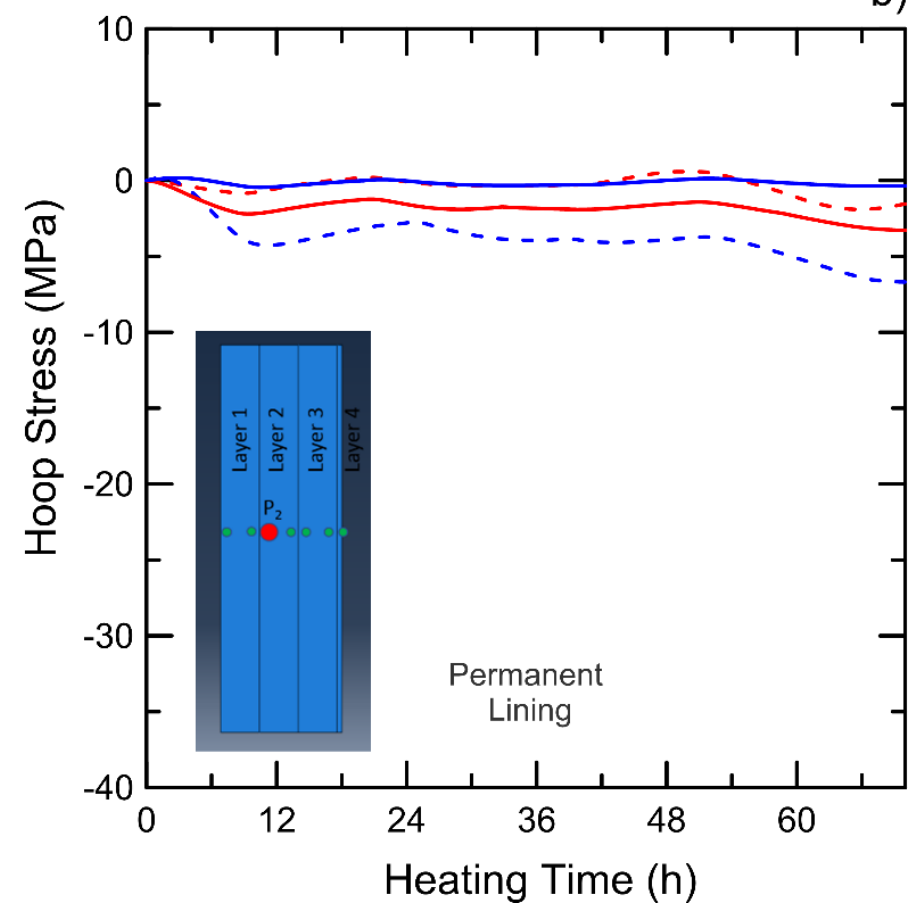




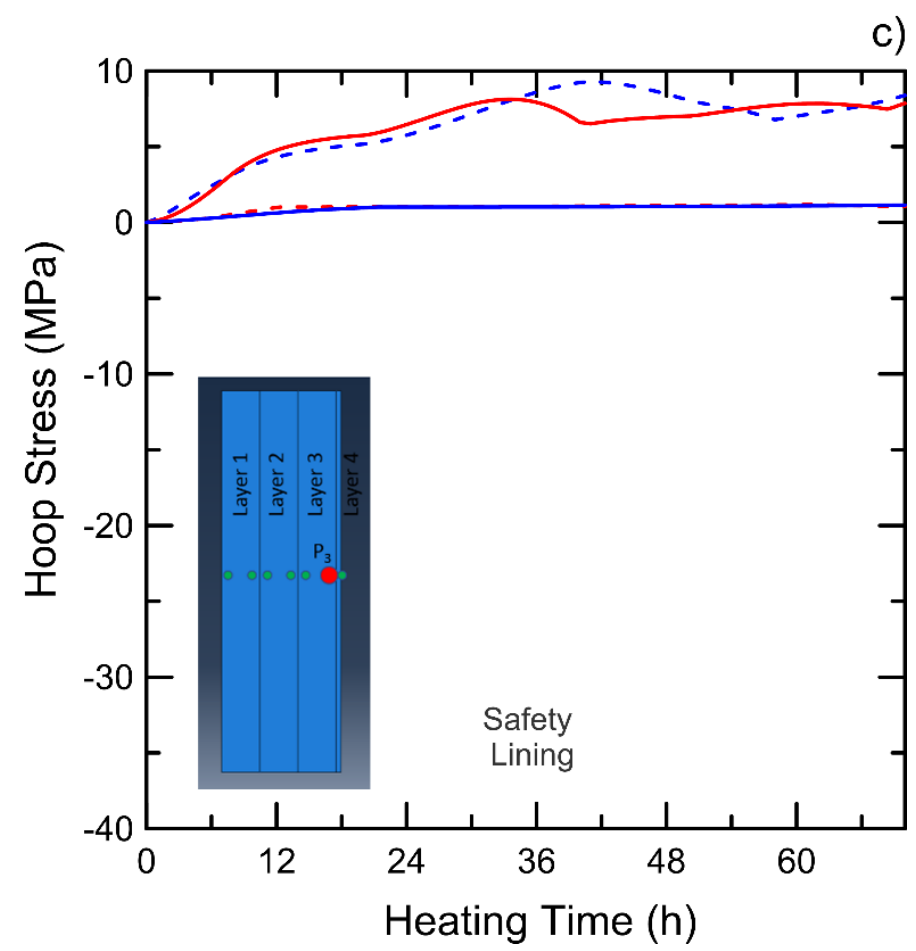

Figure 10 - Hoop thermal stress vs. Heating time at different points of the lining: a) Point 1 wear lining, b) Point 2 permanent lining, c) Point 3 safety lining

\section{Conclusions}

A three-layer lining system using different combinations of three types of refractories is analyzed through finite element simulations of a cylinder under thermo-mechanical loading conditions. From the results obtained that the following conclusions can be drawn:

- More gradual thermal gradients generate smaller strains in the lining layers being less harmful to the system. Steep gradients generate higher thermal stresses and can accelerate the damage in the lining system. The combination of layers $\mid$ A90 | A71 | A51 | produced the more gradual gradient, while the combination of layers | 
A51 | A71 | A90 | resulted the steepest gradient. Thus, adopting the refractory with higher alumina content in the inner layer resulted in the best choice.

- The thermal stress fields exhibited larger tensile regions for the lining combinations in which the refractory A51 was used as the inner layer, i.e. layer receiving the heat flow. However, for the A90 coating combinations as the inner layer, lower regions of tensile stresses are observed, which means a lining less prone to cracking failure.

- The variations of the thermal stresses during the entire heating curve indicated that the outer layer of refractory concrete lining was subjected to tensile stresses for all studied combinations. The maximum compressive stresses in the inner surface were generated at the end of the heating process for all combinations.

- The effect of the internal pressure on the lining stresses is lower for combinations of layers that use the A90 refractory as the inner layer. Also, it is observed that the radial stresses are more affected by the application of internal pressure than the hoop stresses.

- For all cases the use of A90 refractory concrete as an inner layer combined with refractory concretes A71 and A51 as the following layers proved to be more efficient in thermo-mechanical behavior. This is related to the fact that the refractory with higher content of alumina is more efficient to be in contact with the heat flow and the use of more resistant layers near the steel shell.

\section{Acknowledgment}

This work was supported by FAPERJ, CNPq, PUC-Rio and Kerneos aluminate technologies. 


\section{References}

[1] M.M. Akiyoshi, A.L. Christoforo, A.P. Luz, V.C. Pandolfelli, Thermal conductivity modelling based on physical and chemical properties of refractories, Ceram. Int. 43 (2017) 4731-4745. doi:10.1016/j.ceramint.2016.11.091.

[2] A. V. Zabolotsky, Thermal crack growth modeling in refractory linings of metallurgical installations, Int. J. Math. Model. Methods Appl. Sci. 5 (2011) $542-549$.

[3] A. Gasser, P. Boisse, J. Rousseau, Y. Dutheillet, Thermomechanical behaviour analysis and simulation of steel / refractory composite linings, Compos. Sci. Technol. 61 (2001) 2095-2100.

[4] A.M. Brandt, P. Academy, Topic 2 Combining materials : design , production and properties, 88 (1988) 127-130.

[5] T.M. Souza, A.P. Luz, M.A.M. Brito, V.C. Pandolfelli, In situ elastic modulus evaluation of $\mathrm{Al} 2 \mathrm{O} 3-\mathrm{MgO}$ refractory castables, Ceram. Int. 40 (2014) 1699-1707. doi:10.1016/j.ceramint.2013.07.066.

[6] D. Zhang, C. Li, N. Jiang, J. Gao, B. Touzo, W. Yuan, Influence of powder characteristics of reactive alumina on properties of alumina-spinel castables, Ceram. Int. 44 (2018) 9984-9990. doi:10.1016/j.ceramint.2018.03.056.

[7] S. Shi, G. Li, G. Jiang, L. Xie, J. Liu, Temperature and Thermal Stress Analysis of Refractory Products, Sensors \& Transducers. 21 (2013) 53-57.

[8] J. Solarek, C.G. Aneziris, H. Biermann, A new method for manufacturing graded refractories by localized hot uniaxial pressing, Ceram. Int. 43 (2017) 14636-14641. doi:10.1016/j.ceramint.2017.07.167.

[9] B. Glaser, M. Gornerup, D. Sichen, Thermal Modelling of the Ladle Preheating Process, Steel Res. Int. 82 (2011) 1425-1434. doi:10.1002/srin.201100198.

[10] R.T. Committee, Recommendation of RILEM TC 200-HTC : mechanical concrete properties at high temperatures - modelling and applications. Part 2, (2007) 855-864. doi:10.1617/s11527-007-9286-1.

[11] R.T. Committee, Recommendation of RILEM TC 200-HTC : mechanical concrete properties at high temperatures - modelling and applications. Part 1, (2007) 841-853. doi:10.1617/s11527-007-9285-2.

[12] A. Choudhury, S.C. Mondol, S. Sarkar, Finite element Analysis of thermo mechanical stresses of two layered composite cylindrical, Int. J. Res. Appl. Sci. Eng. Technol. 2 (2014) 341-349.

[13] B.E. Byard, A.K. Schindler, Modeling early-age stress development of restrained concrete, (2015) 435-450. doi:10.1617/s11527-013-0194-2. 
[14] H. Awaji, R. Sivakumar, Temperature and Stress Distributions in a Hollow Cylinder of Functionally Graded Material: The Case of TemperatureIndependent Material Properties, J. Am. Ceram. Soc. 84 (2001) 1059-1065. doi:10.1111/j.1151-2916.2001.tb00790.x.

[15] Z.W.Wang, Q.Zhang, L.Z.Xia, J.T.Wu, P.Q.Liu, Stress Analysis and Parameter Optimization of an FGM Pressure Vessel Subjected to ThermoMechanical Loadings, Procedia Eng. $130 \quad$ (2015) 374-389. doi:10.1016/j.proeng.2015.12.230.

[16] B. Lamé, G.; Clapeyron, Mémoire sur l'équilibre intérieur des corps solides homogènes., J. Für Die Reine Und Angew. Math. 7 (n.d.) 33.

[17] S. Zhifei, Z. Taotao, X. Hongjun, Exact solutions of heterogeneous elastic hollow cylinders, Compos. Struct. 79 (2007) 140-147. doi:10.1016/j.compstruct.2005.11.058.

[18] Q. Zhang, Z.W. Wang, C.Y. Tang, D.P. Hu, P.Q. Liu, L.Z. Xia, Analytical solution of the thermo-mechanical stresses in a multilayered composite pressure vessel considering the in fl uence of the closed ends, Int. J. Press. Vessel. Pip. 98 (2012) 102-110. doi:10.1016/j.ijpvp.2012.07.009.

[19] M. Jabbari, M. Meshkini, M.R. Eslami, Mechanical and Thermal Stresses in FGPPM Hollow Cylinder Due to Radially Symmetric Loads, J. Press. Vessel Technol. 138 (2015) 11207. doi:10.1115/1.4031372.

[20] K. Vedeld, H.A. Sollund, J. Hellesland, Closed Analytical Expressions for Stress Distributions in Two-Layer Cylinders and Their Application to Offshore Lined and Clad Pipes, J. Offshore Mech. Arct. Eng. 137 (2016). doi:10.1115/1.4029357.

[21] Z.S. Shao, G.W. Ma, Thermo-mechanical stresses in functionally graded circular hollow cylinder with linearly increasing boundary temperature, Compos. Struct. 83 (2008) 259-265. doi:10.1016/j.compstruct.2007.04.011.

[22] A.R. Shahani, Analytical solution of the quasi-static thermoelasticity problem in a pressurized thick-walled cylinder subjected to transient thermal loading, Appl. Math. Model. 31 (2007) 1807-1818. doi:10.1016/j.apm.2006.06.008.

[23] B. Kanlıkama, A. Abuşoğlu, İ.H. Güzelbey, Coupled thermoelastic analysis of thick-walled pressurized cylinders, Int. J. Energy Power Eng. 2 (2013) 6068. doi:10.11648/j.ijepe.20130202.15.

[24] D. Gruber, K. Andreev, H. Harmuth, FEM simulation of the thermomechanical behaviour of the refractory lining of a blast furnace, $\mathrm{J}$. Mater. Process. Technol. $156 \quad$ (2004) 1539-1543. doi:10.1016/j.jmatprotec.2004.04.249.

[25] W.G. Bareiro, F. de Andrade Silva, E.D. Sotelino, O. da F.M. Gomes, The influence of alumina content on the chemical and mechanical behavior of refractory concretes fired at different temperatures, Constr. Build. Mater. 187 
(2018) 1214-1223. doi:10.1016/j.conbuildmat.2018.08.065.

[26] I.D. Katsavou, M.K. Krokida, I.C. Ziomas, Determination of mechanical properties and thermal treatment behavior of alumina-based refractories, Ceram. Int. 38 (2012) 5747-5756. doi:10.1016/j.ceramint.2012.04.021.

[27] D. Alan, S. Rambo, N. Ukrainczyk, F. De Andrade, E. Koenders, R. Dias, T. Filho, F. Martins, U. Federal, P.O. Box, R. De Janeiro, Calcium-aluminate mortars at high temperatures : Overcoming adverse conversion effects using clinker aggregates, Cem. Concr. Compos. 96 (2019) 212-224. doi:10.1016/j.cemconcomp.2018.12.002.

[28] S. Jin, H. Harmuth, D. Gruber, Thermal and thermomechanical evaluations of channel induction furnace applying strong insulation containing lightweight aggregates, Ironmak. Steelmak. 45 (2018) 514-518. doi:10.1080/03019233.2017.1291153.

[29] G. Li, P. Qu, J. Kong, G. Jiang, L. Xie, Z. Wu, P. Gao, Y. He, Influence of working lining parameters on temperature and stress field of ladle, Appl. $\begin{array}{lllll}\text { Math. Inf. } & \text { Sci. } & 7 & \text { (2013) }\end{array}$ doi:10.4028/www.scientific.net/AMM.121-126.800.

[30] A.S. Nikiforov, E. V. Prikhod'ko, Thermal stresses generated in the lining of a steel ladle, Refract. Ind. Ceram. 46 (2005) 360-363. doi:10.1007/s11148-006-0012-2.

[31] R. Pereira, a. a. Tôrres, M.M. Akiyoshi, V.C. Pandolfelli, Avaliação de taxas de aquecimento em materiais refratários: comparação entre simulações físicas e cálculos computacionais, Cerâmica. 48 (2002). doi:10.1590/S036669132002000200003.

[32] F. Benali, M. Hamidouche, H. Belhouchet, N. Bouaouadja, G. Fantozzi, Thermo-mechanical characterization of a silica-alumina refractory concrete based on calcined algerian kaolin, Ceram. Int. 42 (2016) 9703-9711. doi:10.1016/j.ceramint.2016.03.059.

[33] M.C. de Carvalho, D.R. Oliveira, G.C. Rusky, B.C. Pinheiro, J.A. da S. Souza, E.M. Braga, Computational Simulation of Ladles of steelmaking, Tecnol. Em Metal. Mater. E Mineração. 11 (2014) 138-145.

[34] I.P. Tsibin, A.T. Kuznetsov, A physical model of thermal failure of refractory concretes, Refractories. $29 \quad$ (1988) 43-48. doi:10.1007/BF01386605.

[35] K. Andreev, H. Harmuth, FEM simulation of the thermo-mechanical behaviour and failure of refractories - A case study, J. Mater. Process. Technol. 143-144 (2003) 72-77. doi:10.1016/S0924-0136(03)00322-4.

[36] B. Takabi, Thermomechanical transient analysis of a thick-hollow FGM cylinder, Eng. Solid Mech. 4 (2016) 25-32. doi:10.5267/j.esm.2015.10.002. 


\section{Artigo C Thermo-mechanical behavior of stainless steel fiber reinforced refractory concrete: experimental and numerical analysis}

Walter Gabriel Bareiro ${ }^{\text {a }}$, Elisa Dominguez Sotelino ${ }^{\text {a }}$ and Flávio de Andrade Silva

${ }^{a}$ Department of Civil and Environmental Engineering, Pontifícia Universidade Católica do Rio de Janeiro, (PUC-Rio), Rua Marquês de São Vicente 225, 22451900, Gávea, Rio de Janeiro - RJ, Brazil 


\begin{abstract}
Reinforcing refractory concretes with stainless steel fibers can improve their thermomechanical behavior, and, thus, these materials have the potential of becoming a new solution for applications subjected to high thermomechanical loads. The improvement of adding the fibers depends on the fiber material, shape and volume fraction. In addition, the firing temperatures influence the thermomechanical behavior of fiber reinforced refractory concrete. The purpose of this research is to investigate the thermomechanical behavior of the alumina based refractory concrete reinforced with different types of stainless steel fibers. Straight, wavy and knurled shape stainless steel fibers were selected for the study. A research program of experimental test and numerical simulations was carried out. Three points bending tests, pull-out fiber tests, direct tensile tests and compression tests are performed at the $25-1200^{\circ} \mathrm{C}$ temperature range to obtain the mechanical residual values in order to develop experimental constitutive models. The experimental tests allowed to develop the constitutive model of the material that was implemented in the finite element program ABAQUS. The constitutive model was validated through thermomechanical simulations of the round panel test. The digital image correlation (DIC) analysis was coupled with the three-point bending tests to obtain strain fields and study the propagation of cracks at various temperatures. The flexural results showed better behavior for the reinforcement with knurled fiber for all temperatures due to their higher bond with the matrix. The experimental tests and the numerical simulations showed that the reinforcement effect benefits the prepeak and post-peak behavior of the refractory concretes. The influence on the softening curves indicates the importance for the structural projects.
\end{abstract}


Keywords: Refractory composites, stainless steel fiber, shapes, thermomechanical behavior, non-linear simulation.

\section{Introduction}

Refractory concretes are widely used in metallurgical and petrochemical industries, thermal plants and blast furnaces. The mechanical behavior of steel fiber reinforced concrete (SFRC) is mainly linked to a number of factors such as: fiber geometry, fiber volumetric fraction and type of fiber material. For refractory concretes, the firing and testing temperature highly influences its thermomechanical behavior as shown in previous research [1], which relates this influence to the microstructural evolutions for unreinforced alumina concretes. On the other hand, some works to understand the effects of reinforcement and temperature increase on the mechanical properties in reinforced refractory concretes have been with stainless steel fibers [2-4]. In the relatively recent time of using these materials in diverse applications, fiber reinforced refractory suppliers and users use standard steel fiber as cost-effective. Therefore, new alternatives for the use of other types of fibers that can optimize composite behavior performance becomes an area to be investigated. Therefore, little information is available on the effect of fiber types and shape on refractory concrete's behavior, in particular, at different temperatures [4]. Among the works found on the subject, they address the behavior of the materials in a limited temperature range and for standard steel fibers. Cutard et al. [2] studied the effects of metallic fiber reinforcement on the mechanical behavior of a $\mathrm{SiC}$ based refractory concrete behavior of refractory concretes up to $400^{\circ} \mathrm{C}$ for tool applications. These materials are subjected to thermal loads, the thermal stresses due to successive heating and cooling processes, with mechanical pressure, 
can cause permanent deformations and even material failure. They showed that the use of the fibers brings benefits in the pre-peak and post-peak mechanical behavior of the refractory concrete and that each fiber reinforcement had a specific effect on the behavior. Also, it was concluded that these effects in such a material depend mainly on the type of fiber, volumetric fraction, thermal treatment and the testing temperature. The toughness as defined by ASTM C1018 [5] is a ratio of the amount of energy required to deflect a fiber concrete beam by a prescribed amount of the energy required to bring the fiber beam to the point of the first crack. This test method provides for the determination of a number of ratios that serve as toughness indices which identify the pattern of material behavior. Meddah et al. [4] investigated the effect of the fiber geometry on the flexural properties of reinforced steel fiber refractory concrete. From the results obtained throughout this experimental study, the relationship between fiber geometry and toughness is presented. The toughness indices increased with increasing aspect ratio, fiber length at constant aspect ratio. However, at high aspect ratio, as well as high fiber length, the increase is less visible. The results suggest that a fiber aspect ratio of around 80 is the most appropriate for toughness performance.

In the present study, the behavior of refractory concretes based on alumina content with stainless steel fiber reinforced is investigated. Different fibers shapes are added to the refractory matrix in volume fraction of $1,2,3 \%$, because these values correspond to a low, medium and high volumetric fraction respectively, and how they influence on the behavior of the composite. The characterization of the thermomechanical behavior of refractory composites were determined by tests performed at room temperature, for specimens that had been exposed to 25, 600 and $1000^{\circ} \mathrm{C}$. Different types of experimental tests were performed, namely: tensile 
direct tests, compression tests, bending tests, pullout fiber tests and structural tests. The mechanical tests allowed to develop the constitutive model of the material that was implemented in the finite element program ABAQUS. The constitutive model was validated through thermomechanical simulations of the round panel test. This means that the constitutive model enables numerical simulations of structural tests of larger specimens at different temperatures from the thermomechanical characterization of the material through several tests. The advantage is that the sample for these tests can be fired at different temperatures in conventional sized furnaces or smaller coupled firing equipment.

\section{Materials and experimental procedure}

\subsection{Refractory concrete matrix}

Calcium aluminate cement (Secar 51) by Kerneos Inc. was used in the production of refractory concretes with $51 \mathrm{wt} . \%$ alumina contents (A51). The aggregate was a Alag fino from Kerneos with size distribution ranging from $0.001 \mathrm{~mm}$ to $1.18 \mathrm{~mm}$ in diameter. A superplasticizer (Peramin CONPAC 50 Kerneos Inc.) and a viscosity modifier agent (VMA) Rheomac UW 410 BASF were used. The first part of mixing process consisted of mixing the dry materials were mixed for 1 min with planetary mixer. Then, the water was added and blended for 4 min and after that, the VMA was incorporated. After 6 min of mixing time the fibers were added and left to mix for another $8 \mathrm{~min}$. The chemical composition (\% weight) of refractory concrete determined in the previous study [1] is shown in the Table 1.

Table 1 - Chemical Analysis Refractory Concretes 


\begin{tabular}{lc}
\hline Components (\%wt.) & A51 \\
\hline $\mathrm{Al}_{2} \mathrm{O}_{3}$ & 49.42 \\
\hline $\mathrm{CaO}$ & 35.70 \\
\hline $\mathrm{Fe}_{2} \mathrm{O}_{3}$ & 8.20 \\
\hline $\mathrm{SiO}_{2}$ & 4.15 \\
\hline $\mathrm{TiO}_{2}$ & 1.74 \\
\hline $\mathrm{BaO}$ & - \\
\hline $\mathrm{K} 2 \mathrm{O}$ & 0.40 \\
\hline $\mathrm{MnO}$ & 0.13 \\
\hline $\mathrm{V}_{2} \mathrm{O}_{5}$ & 0.10 \\
\hline $\mathrm{Cr}_{2} \mathrm{O}_{3}$ & 0.07 \\
\hline $\mathrm{ZrO}$ & 0.07 \\
\hline $\mathrm{SrO}$ & 0.03 \\
\hline
\end{tabular}

\subsection{Stainless Steel fibers}

Three forms of stainless steel fibers were studied as reinforcement for the refractory concrete: straight, wavy and knurled (their images are shown in Table 1).

All fibers had a length of $20 \mathrm{~mm}$ with aspect ratio of $40(\mathrm{~d}=0.50 \mathrm{~mm})$. Chemical composition and physical and mechanical properties of stainless steel fiber are detailed in Table 2 and Table 3, respectively, according to their manufacture.

Table 2 - Chemical composition of stainless steel

\begin{tabular}{lc}
\hline Components (\%wt.) & Stainless Steel \\
\hline Chrome & $17-20$ \\
\hline Nickel & $34-37$ \\
\hline Carbon & 0.20 \\
\hline Manganese & 2.00 \\
\hline Phosphorus & 0.04 \\
\hline Sulfur & 0.03 \\
\hline Silicon & 0.75 \\
\hline
\end{tabular}

Table 3 - Physical and mechanical properties of stainless steel fiber

\begin{tabular}{lccc}
\hline Properties & $\begin{array}{c}\text { Straight } \\
\text { Fiber }\end{array}$ & $\begin{array}{c}\text { Wavy } \\
\text { Fiber }\end{array}$ & $\begin{array}{c}\text { Knurled } \\
\text { Fiber }\end{array}$ \\
\hline & & & \\
\hline Fiber Type & Astra AISI 330 & Astra AISI 330 & Astra AISI 330 \\
\hline Length $(\mathrm{mm})$ & 25.00 & 25.00 & 25.00 \\
\hline Diameter $(\mathrm{mm})$ & 0.50 & 0.50 & 0.50 \\
\hline Aspect Ratio & 50.00 & 50 & 50 \\
\hline
\end{tabular}




\begin{tabular}{lccc}
\hline $\begin{array}{l}\text { Tensile Stress }(\mathrm{MPa}) \text { at room } \\
\text { temperature } 25^{\circ} \mathrm{C}\end{array}$ & 1174.50 & 1174.50 & 1174.50 \\
\hline $\begin{array}{l}\text { Yield Stress }(\mathrm{MPa}) \text { at room } \\
\text { temperature }\left(25^{\circ} \mathrm{C}\right)\end{array}$ & 206.80 & 206.80 & 206.80 \\
\hline $\begin{array}{l}\text { Elastic Modulus }(\mathrm{GPa}) \text { at room } \\
\text { temperature } 25^{\circ} \mathrm{C}\end{array}$ & 195.10 & 195.10 & 195.10 \\
\hline Elastic Modulus $(\mathrm{GPa})$ at $870^{\circ} \mathrm{C}$ & 134.00 & 134.00 & 134.00 \\
\hline Density $\left(\mathrm{kg} / \mathrm{m}^{3}\right)$ & 7950 & 7950 & 7950 \\
\hline Melting point range $\left({ }^{\circ} \mathrm{C}\right)$ & $1400-1425$ & $1400-1425$ & $1400-1425$ \\
\hline $\begin{array}{l}\text { Expansion Coefficient } 870{ }^{\circ} \mathrm{C}\left(10^{6}\right. \\
\text { o } \mathrm{C})\end{array}$ & 17.64 & 17.64 & 17.64 \\
\hline
\end{tabular}

\section{Mechanical test}

The samples molded: prisms, cylinders, dog bone and round panel for three point bending test, cyclic test, compression test, tensile test and round panel test, respectively, were cured for 7 days and then, with the exception for the round panel and the dog bone for direct tensile that were only tested at $25^{\circ} \mathrm{C}$, the other samples were exposed at different temperatures $\left(25,600\right.$ and $\left.1000^{\circ} \mathrm{C}\right)$ prior to mechanical tests. The pullout test samples were exposed at $25,600,900,1000$ and $1200^{\circ} \mathrm{C}$. Unfired samples $\left(25^{\circ} \mathrm{C}\right)$ were also characterized for reference. For the heating process a rate of $10^{\circ} \mathrm{C} / \mathrm{min}$ was applied until reaching the final temperature (600 and $1000^{\circ} \mathrm{C}$ ) and maintaining at that temperature for 1 hour. An electric furnace SPLabor was used. The cooling process was not controlled, i.e., it occurred naturally inside the furnace.

\subsection{Monotonic three-point bending test}

Monotonic three-point bending tests were performed to characterize thermomechanical behavior of a refractory concrete reinforced with stainless steel fibers. The crack propagation and the fracture behavior were monitored, based on the approach presented in RILEM TC-162 [6]. Three pre-notched prismatic 
specimens were produced for each refractory concrete mix, with cross section of 40 $\mathrm{mm} \times 40 \mathrm{~mm}$, length of $160 \mathrm{~mm}$ and notch of $12 \mathrm{~mm}$. A MTS servo-controlled hydraulic testing machine (Figure 1) was used to conduct closed-loop flexural tests. The crack mouth opening displacement (CMOD) was measured and used as the test control signal. A constant rate of $0.10 \mathrm{~mm} / \mathrm{min}$ was set using a clip-gauge and limited to $4 \mathrm{~mm}$ opening.

The bending tests were performed on various refractory concrete samples by varying the stainless fiber shapes and fiber volume fraction of 1, 2 and $3 \%$ (i.e. 79 $\mathrm{kg} / \mathrm{m}^{3}, 160 \mathrm{~kg} / \mathrm{m}^{3}$ and $240 \mathrm{~kg} / \mathrm{m}^{3}$ ) and by exposing them at room temperature $\left(25^{\circ} \mathrm{C}\right), 600$ and $1000^{\circ} \mathrm{C}$.
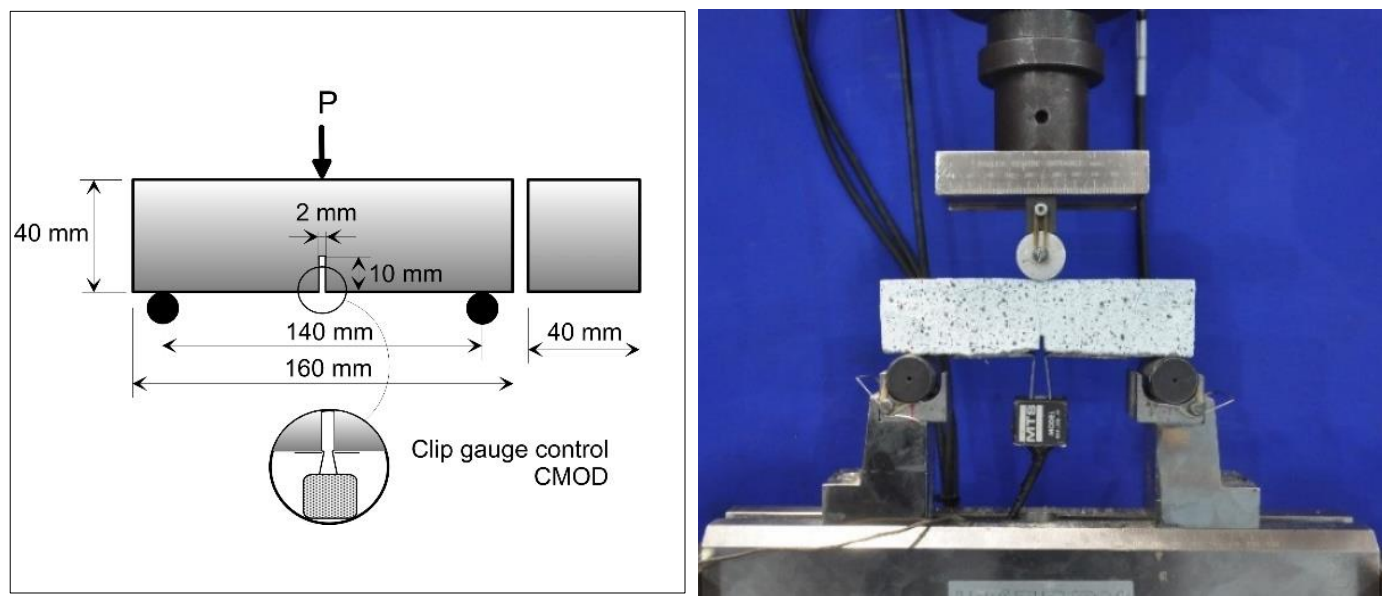

Figure 1 - Three-point bending tests set-up, prism sample in accordance with RILEM TC-162.

\subsection{Fiber pullout test}

The pullout tests were performed using cylindrical specimens measuring $20 \mathrm{~mm}$ of diameter and $12,5 \mathrm{~mm}$ in length. The total length of the fiber is $25 \mathrm{~mm}$. Ten tests were carried on for each type of fiber and for each temperature $(25,600$, 900,1000 and $\left.1100^{\circ} \mathrm{C}\right)$. A fiber embedment length $\left(\mathrm{L}_{\mathrm{f}}\right)$ of $12,50 \mathrm{~mm}$ was used, i.e. 
half of the fiber was embedded in the matrix. The firing process was the same as for the samples from the other tests, rate of $10^{\circ} \mathrm{C} / \mathrm{min}$ with the temperature reached for 1 hour. A MTS 810 servo-controlled hydraulic-system, with $250 \mathrm{kN}$ capacity were used. The tests were controlled by the internal LVDT displacement at a rate of $1.5 \mathrm{~mm} / \mathrm{min}$ with a $2.5 \mathrm{kN}$ load cell attached to the crosshead, allowing a maximum displacement of $20 \mathrm{~mm}$. The specimens were fixed at the bottom inside a metal cup and the fiber was pulled out with a metal claw. Figure 2 shows the complete test setup.
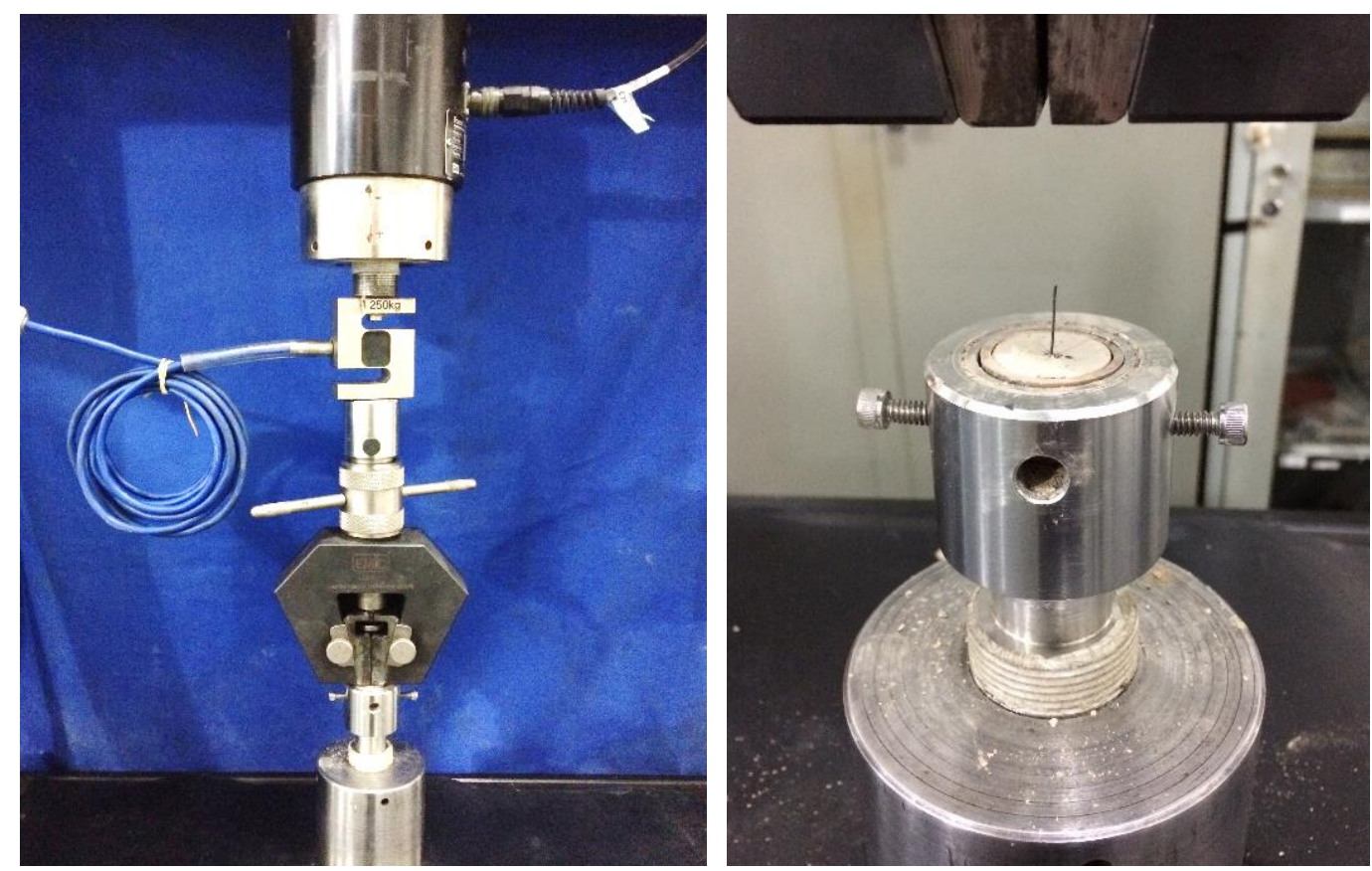

Figure 2 - Pullout test set-up for stainless steel fiber and cylindrical sample detail

\subsection{Cyclic test}

The cyclic tests were performed in the similar way to monotonic tests, i.e., the prismatic specimens were pre-notched and tested under there-point bending using the same machine. However, the cyclic regime (loading-unloading) was 
implemented in accordance with the RILEM 89-FMT recommendation. The loading part of each cycle was controlled by a CMOD signal until reaching predefined crack opening. The unloading part for every cycle was controlled by the force control until the specified load values $(0.1-1 \mathrm{kN})$ under a constant rate of $8 \mathrm{kN} / \mathrm{min}$. The cyclic test involved CMOD levels of $0.02,0.04,0.06,0.10,0.14$, $0.18,0.30,0.50$ and $4.00 \mathrm{~mm}$. Up to a crack mouth of $0.18 \mathrm{~mm}$, the displacement rate applied to the specimen was $0.05 \mathrm{~mm} / \mathrm{min}$ and from a crack mouth of $0.18 \mathrm{~mm}$ to $4.00 \mathrm{~mm}$ the rate was $0.20 \mathrm{~mm} / \mathrm{min}$.

\subsection{Compression test}

Compression tests were performed on cylindrical samples measuring $50 \mathrm{~mm}$ x $100 \mathrm{~mm}$ (diameter $\mathrm{x}$ height) following ASTM C133 using a servo-hydraulic testing machine MTS 810. A head block with a spherical kneecap was used on the flat surface of the sample. The tests were controlled by the actuator displacement at the rate of $0.4 \mathrm{~mm} / \mathrm{min}$. The axial displacement was measured using two LVDT's attached to the sample.

\subsection{Round Panel tests}

The round panel tests, considered as structural tests, were performed according to ASTM: C1550. The circular panels had nominal diameter $800 \mathrm{~mm}$ and the thickness $80 \mathrm{~mm}$. Three symmetrically arranged pivots (50 $\mathrm{mm}$ of diameter) were used to support the samples in the configurations shown in the Figure 3. The testes were carried on using a servo - hydraulic actuator (500 kN capacity) controlled by an MTSflextest 60 controller. The central load was applied on the upper surface of the sample at an actuator displacement rate of $2 \mathrm{~mm} / \mathrm{min}$. The 
deflection response (until $30 \mathrm{~mm}$ ) was measured using a displacement transducer (Gefran $100 \mathrm{~mm}$ ) positioned at the central part of the bottom surface of the specimens. The opening of cracks in the bottom surface were measured by 3 displacement transducers (Gefran $50 \mathrm{~mm}$ ) arranged in a triangular shape (equal sides of $120 \mathrm{~mm}$ ) concentric with the panel (see Fig. 3).

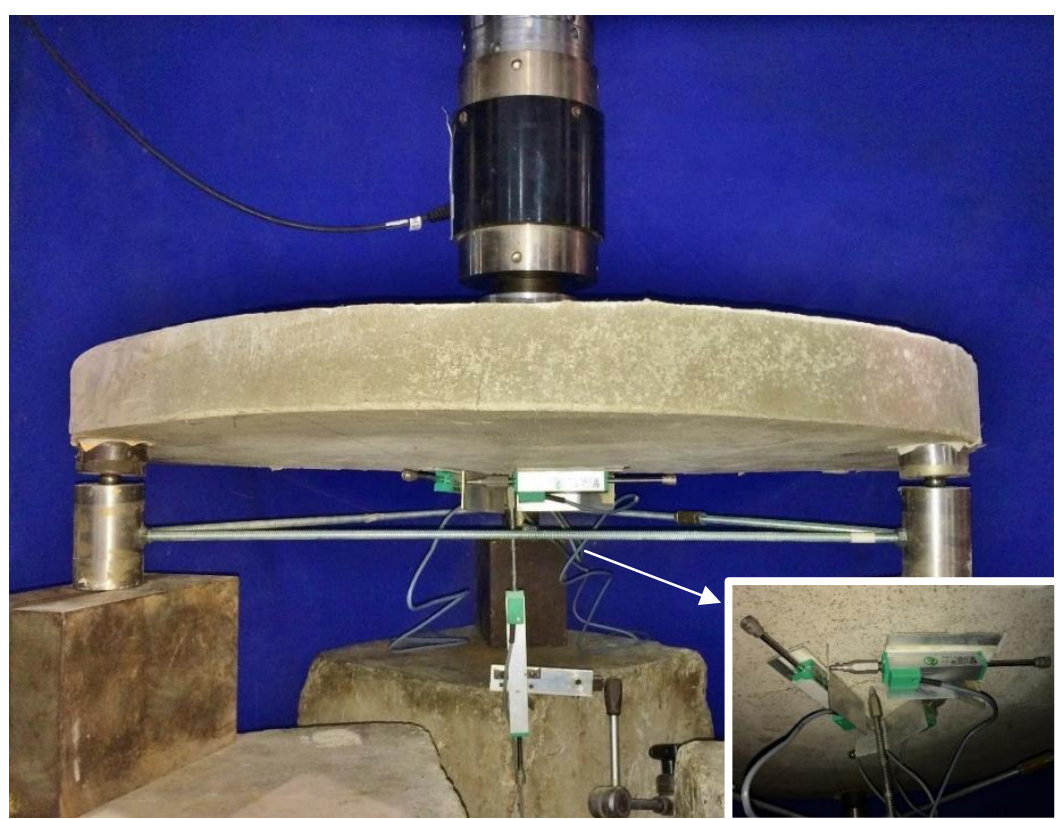

Figure 3 - Round panel test set-up and detail of the crack opening measurement system.

\subsection{Direct Tensile Test}

Direct tensile tests were performed using dog bone shape specimens of 500 $\mathrm{mm}$ in length and ends of $150 \mathrm{~mm}$ in diameter with a central section of $68 \mathrm{~mm}$ in diameter (see Figure 4). The test machine used was the MTS model 311 universal test, with a maximum load of $1200 \mathrm{kN}$ capacity. A pair of LVDTs (HBM $50 \mathrm{~mm}$ ) were positioned on the specimen. The tests were controlled by the actuator displacement rate of $0.1 \mathrm{~mm} / \mathrm{min}$. The data recorded were: the tensile load, actuator displacement and LVDTs displacements. 

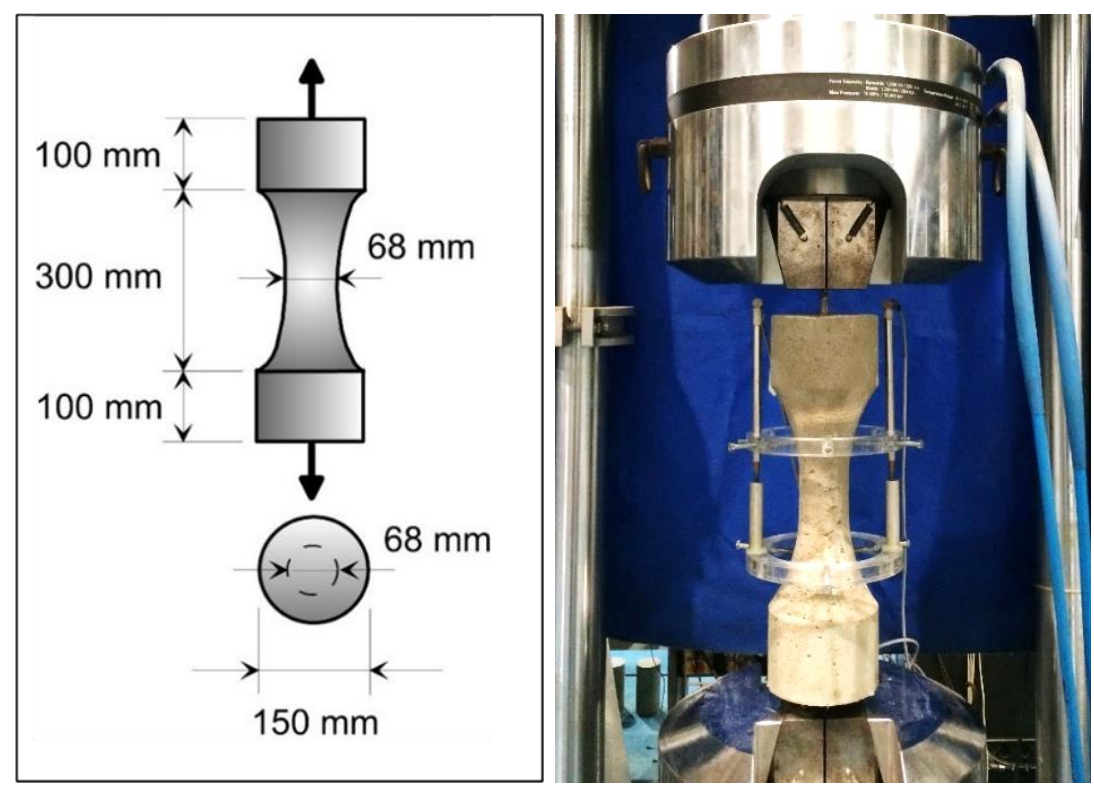

Figure 4 - Direct tensile test set-up and dog bone specimen

\section{Numerical model}

The nonlinear behavior of the refractory concretes was modeled using the concrete damage plasticity (CDP) and implemented in the commercial FEM software ABAQUS. The constitutive relations and properties of the materials obtained in the different mechanical tests such as tensile tests, compressive tests and three-point bending tests were used to implement the constitutive model in ABAQUS. Several points of stress-strain curves of compressive behavior and tensile behavior, were calculated for this input at software, and entered into the values in table form. First, the constitutive parameters of CDP were identified. In ABAQUS the parameters required to define the model consists of six: the Poisson's ratio $(v)$, angle of dilation $(\psi)$, an eccentricity $(\epsilon)$, the ratio of compressive yield stresses $\left(\sigma_{\mathrm{b} 0} / \sigma_{\mathrm{c} 0}\right)$, viscosity $(\mu)$ and $\mathrm{Kc}$ is the ratio between the stress invariant on the tensile meridian and the compression meridian, parameter defined on the basis of the complete triaxial test of the concrete, standard value $2 / 3$. Then, the constitutive relations of material (compression and tensile) obtained in the different 
tests were implemented. The validation of the developed constitutive models was done through the simulation of the round panel test and three-point bending tests. Some screenshots of the implementation in the program are shown in the Figure 5. The values of the parameters of the constitutive model CDP and the compressive and tensile behavior used in the FEM model, for each temperature tested, are detailed further in the Section 6.5.1 in the Tables 10-11.

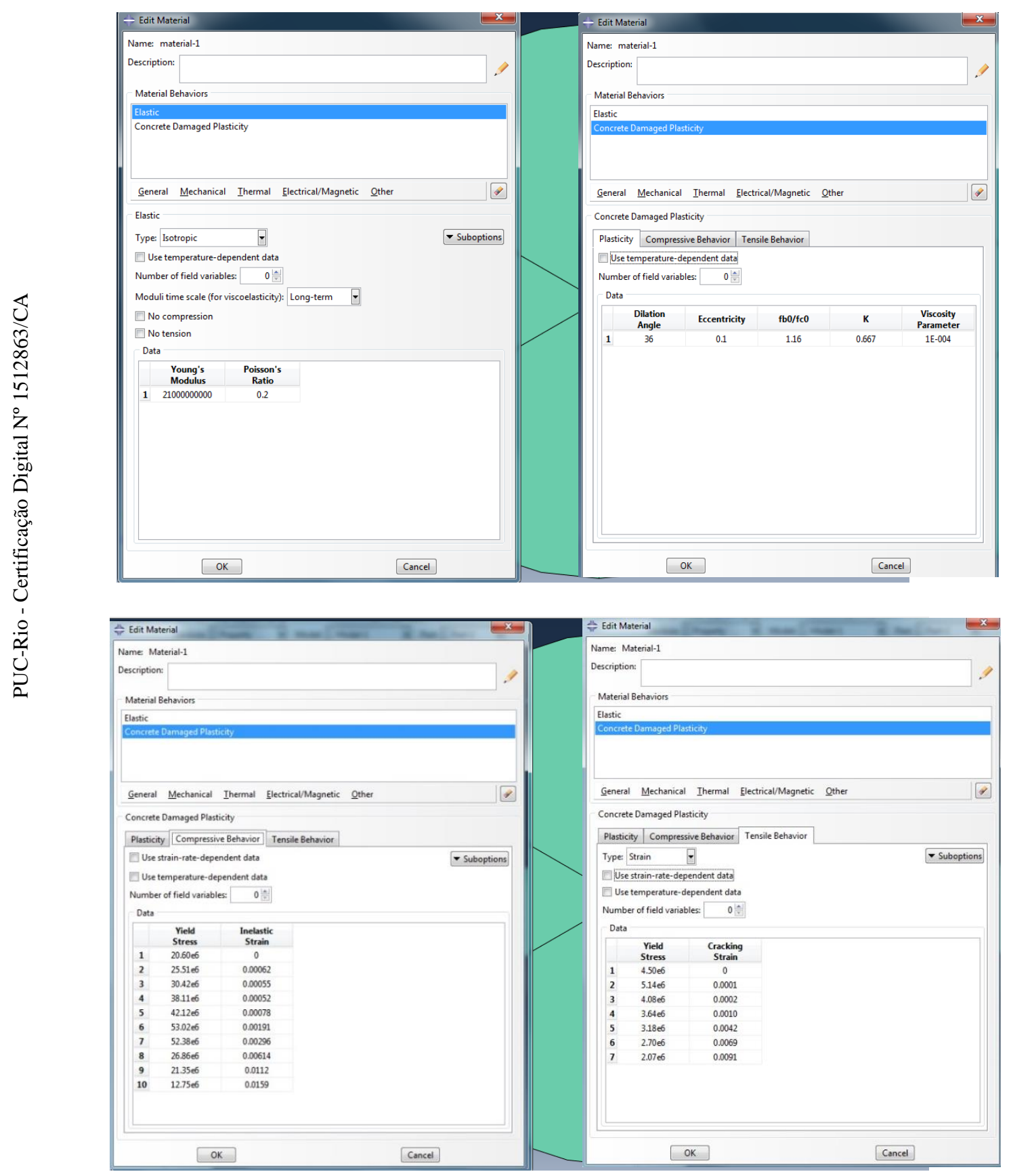

Figure 5 - CDP Model implementation in ABAQUS 


\section{Digital image correlation}

For the three-point bending tests the propagation of the crack opening was monitored for specimens exposed at different temperatures $\left(25,600\right.$ and $\left.1000^{\circ} \mathrm{C}\right)$ using digital image correlation (DIC) methods. The focus is to evaluate the strain fields and to measure the cracks in different steps. The DIC system records the sample displacements in the notch region by taking photographs with a frequency of $5 \mathrm{~Hz}$. The strain fields were obtained using the GOM correlate software, which is a free digital image correlation and evaluation software for materials and components testing. The equipment consisted of a professional Nikon D90 camera controlled by DigiCam Control software.

\section{Discussion and analyses}

\subsection{Flexural tests results of stainless steel fiber reinforced refractory concrete}

The results obtained from monotonic three-point bending test on notched specimens are presented in the stress- CMOD (crack mouth opening displacement) curves shown in Figures 6-8 for the different fiber shapes (straight, wavy and knurled) and for the different temperature exposures $\left(25,600\right.$ and $\left.1000^{\circ} \mathrm{C}\right)$. The total number of 108 specimens were tested, considering 3 specimens for each type of composite. The flexural response was obtained on prisms reinforced with $1.00 \%, 2.00 \%$ and $3.00 \%$ of volume fraction for the three types of stainless steel fibers.

The mechanical parameters identified from the curves are given in Table 35. According to EN14651 [7], the stress at the limit of proportionality (LOP) is calculated considering the highest load value in the interval for crack opening of 
$0.05 \mathrm{~mm}$. The modulus of rupture (MOR) is defined as the point at which the softening starts. The flexural residual stress $f_{R i}$ are also obtained from curves for the points $i=1,2$ and 3, for CMOD values of $0.5,1.5$ and $2.5 \mathrm{~mm}$, respectively, as defined in the Model Code 2010 [8]. The toughness values (T) are given by the total area under the load-CMOD curve until 2mm of CMOD.

The behavior of the unfired refractory concrete (matrix) only cured is characteristic of a brittle material, with an elastic zone before cracking and then a rapid stress decrease after the peak. However, its behavior after being fired at high temperatures $\left(600-1000^{\circ} \mathrm{C}\right)$ is elasto-viscoplastic, since it better captures its postpeak.

The results from the tests show that reinforcement with the fibers considerably improves the mechanical behavior of the refractory composite, specifically in terms of the residual flexural stress and toughness. The influence of the fiber shape on the enhanced mechanical bending behavior was also observed. Figure 6 reports the representative results from the monotonic threepoint bending tests performed on cured fiber reinforced refractory concrete (FRRC) at ambient temperature $\left(25^{\circ} \mathrm{C}\right)$ for $1.00 \%, 2.00 \%$ and $3.00 \%$ of fiber volume fractions of straight fiber (STR), wavy fiber (WAV) and knurled (KNU). The results for the different fibers showed differences in the LOP and MOR for the same volumetric fraction. The most significant increase of these parameters was for the knurled fibers $(\mathrm{LOP}=10 \mathrm{MPa}$ ) when compared to the wavy fiber (LOP $=6 \mathrm{MPa})$ and the straight fiber $(\mathrm{LOP}=4 \mathrm{MPa})$. Before the peak stress, a nonlinear part occurs due to the development of diffuse damage by a microcraking process. Once the peak stress is exceeded, the load-deformation curve experiences softening until the load it becomes almost constant. 
In order to classify the post-cracking strength of FRRC, were considered the characteristic residual strengths significant for service $\left(f_{R 1}\right)$ and ultimate $\left(f_{R 3}\right)$ conditions. This post-craking residual strength was classified using two parameters, the interval strength $f_{R I k}$ and letter $a, b, c, d$ or $e$, according to the ratio $f_{R 3} / f_{R I}$ (Table 4).

Table 4 - Classification post-cracking residual strength fb Model Code 2010

\begin{tabular}{cc}
\hline Classification & Condition \\
& \\
\hline$a$ & $0.50<f_{R 3} / f_{R 1} \leq 0.70$ \\
\hline$b$ & $0.70<f_{R 3} / f_{R 1} \leq 0.90$ \\
\hline$c$ & $0.90<f_{R 3} / f_{R 1} \leq 1.10$ \\
\hline$d$ & $1.10<f_{R 3} / f_{R 1} \leq 1.30$ \\
\hline$e$ & $1.30<f_{R 3} / f_{R 1}$ \\
\hline
\end{tabular}

Figure 7-8 shows the representative thermomechanical behavior from the three-point bending tests performed on FRRC fired samples at 600 and $1000^{\circ} \mathrm{C}$, respectively. In these cases, the firing temperature of FRRC composites develops in the test, a high softening behavior and a decrease of the peak stress values. However, post-peak stress values show little decrease. Indeed, the softening slopes are less pronounced at high temperature. Table 5 to Table 7 The experimental results of peak and post-peak parameters for the monotonic three-point bending tests for exposed sample at $25^{\circ} \mathrm{C}, 600^{\circ} \mathrm{C}$ and $1000^{\circ} \mathrm{C}$. The symbols for the refractory composites chosen according to fiber form used STR (straight), WAV (wavy) or $\mathrm{KNU}$ (knitted) followed by the volumetric fraction $(1 \%, 2 \%$ or $3 \%)$ and the exposed temperature. For example: STR $1 \% 25^{\circ} \mathrm{C}$.

The difference in peak stress and toughness for the different fiber for firing temperatures of 600 and $1000^{\circ} \mathrm{C}$ were of the same order of magnitude as for ambient temperature. Higher values of post-peak strength were obtained for higher fiber 
volume fractions for all fibers, with the highest values obtained for the composite with knurled fiber. The use of $2 \%$ of knurled fiber (KNU2\%) was selected for the other composite characterization tests because it presented the better performance and because of the ease of mixing at different temperatures. Moreover, KNU2\% could maintain the residual stress after MOR practically constant at the different temperatures tested.

The distinct flexural performance between the three fibers is associated with the shape and the adhesion of the fiber to the matrix. The interfacial shear mechanism is one of the main factors to control the pullout process of the fiber, such the aspect ratio. Higher values of these factors lead to stronger bond with the matrix [9]. The characterization of the parameters of the pullout process for the three fiber forms are discussed in the following section.

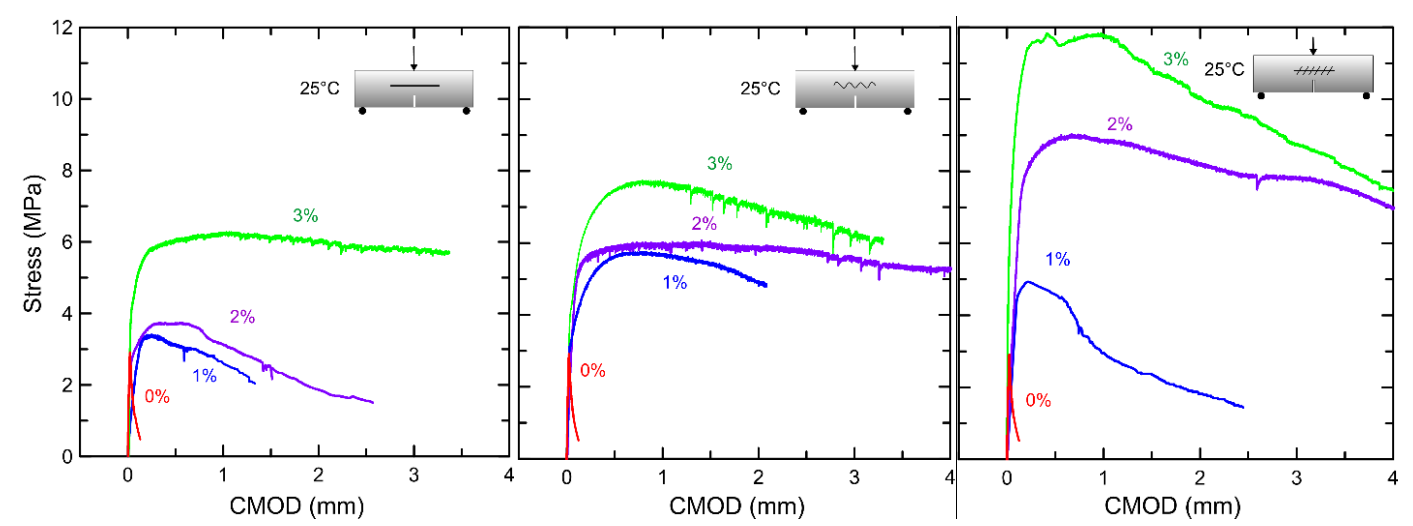

Figure 6 - Results from monotonic three-point bending tests performed on RC at $25^{\circ} \mathrm{C}$ with different shapes of stainless steel fiber a) straight b) wavy c) knurled, and different volume ratio of fibers. 


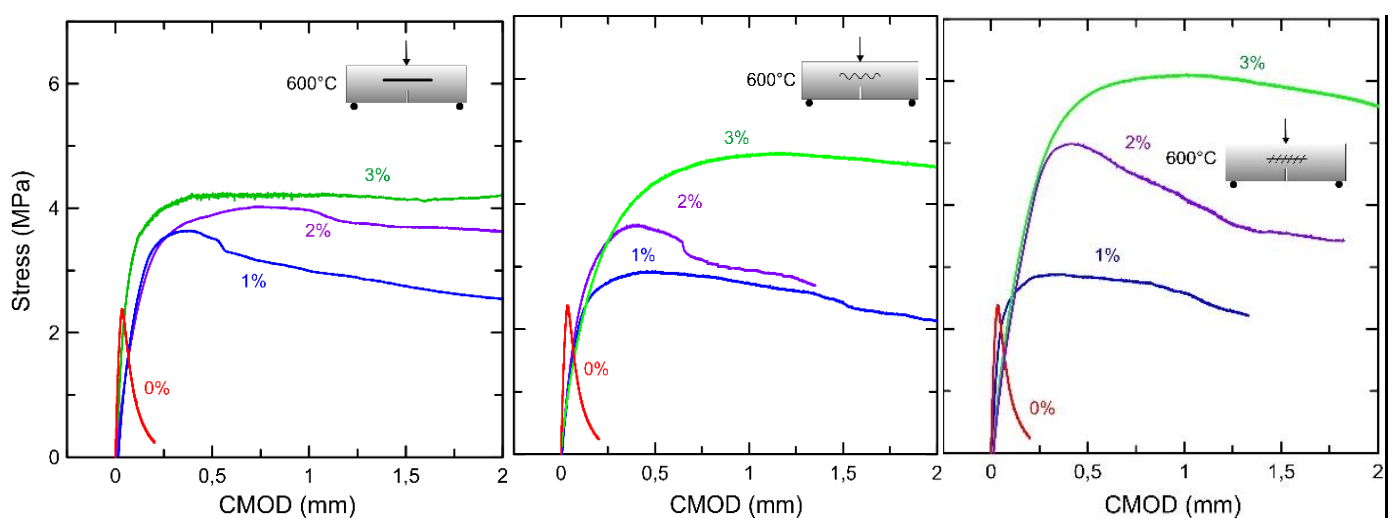

Figure 7 - Results from monotonic three-point bending tests performed on $\mathrm{RC}$ at $600^{\circ} \mathrm{C}$ with different shapes of stainless steel fiber a) straight b) wavy c) knurled, and different volume ratio of fibers.

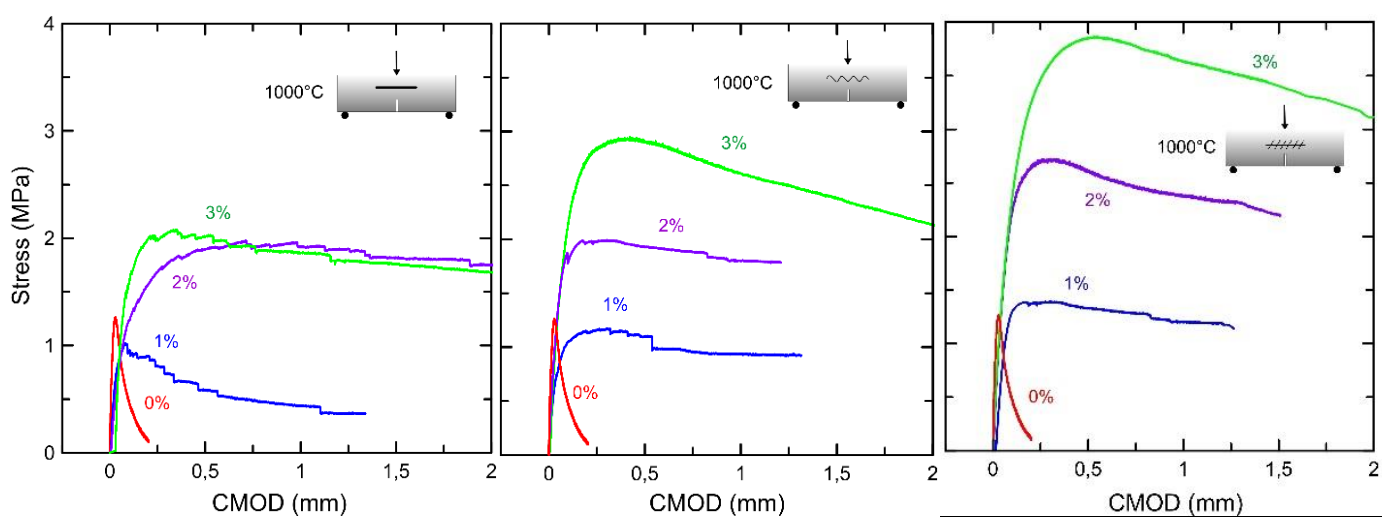

Figure 8 - Results from monotonic three-point bending tests performed on $\mathrm{RC}$ at $1000^{\circ} \mathrm{C}$ with different shapes of stainless steel fiber a) straight b) wavy c) knurled, and different volume ratio of fibers.

Table 5-Experimental results of peak and post-peak parameters for the monotonic three-point bending tests only cured sample $25^{\circ} \mathrm{C}$.

\begin{tabular}{|c|c|c|c|c|c|c|c|c|c|c|c|}
\hline Mix & $\begin{array}{l}P_{\text {lop }} \\
\text { (kN) }\end{array}$ & $\begin{array}{c}\sigma_{\text {lop }} \\
(\mathrm{MPa})\end{array}$ & $\begin{array}{c}\mathrm{Pu} \\
(\mathrm{kN})\end{array}$ & $\begin{array}{l}\text { MOR } \\
\text { (MPa) }\end{array}$ & $\begin{array}{c}\text { CMOD } \\
\text { MOR } \\
(\mathrm{mm})\end{array}$ & $\begin{array}{c}\mathbf{f}_{\mathrm{R} 1} \\
(\mathrm{MPa})\end{array}$ & $\begin{array}{c}\mathbf{f}_{\mathrm{R} 2} \\
\text { (MPa) }\end{array}$ & $\begin{array}{c}\mathbf{f}_{\mathrm{R} 3} \\
(\mathrm{MPa})\end{array}$ & $\begin{array}{c}T_{2.0} \\
(J)\end{array}$ & $\begin{array}{c}\mathbf{f}_{\mathrm{R} 3} / \\
\mathbf{f}_{\mathrm{R} 1}\end{array}$ & $\begin{array}{l}G_{F} \\
(J)\end{array}$ \\
\hline $\begin{array}{l}\text { Matrix } \\
25^{\circ} \mathrm{C}\end{array}$ & 0.89 & 2.91 & - & - & - & - & - & - & 0.13 & - & 0.10 \\
\hline $\begin{array}{l}\text { STR1\% } \\
25^{\circ} \mathrm{C}\end{array}$ & 0.97 & 3.20 & 1.03 & 3.41 & 0.25 & 3.11 & 1.83 & 1.83 & 4.04 & 0.59 & 3.39 \\
\hline $\begin{array}{l}\text { STR2\% } \\
25^{\circ} \mathrm{C}\end{array}$ & 0.91 & 3.00 & 1.14 & 3.74 & 0.35 & 3.71 & 2.53 & 1.54 & 6.86 & 0.51 & 5.77 \\
\hline $\begin{array}{l}\text { STR3\% } \\
25^{\circ} \mathrm{C}\end{array}$ & 1.25 & 4.10 & 1.91 & 6.27 & 1.05 & 6.03 & 6.09 & 5.83 & $\begin{array}{c}19.8 \\
3\end{array}$ & 0.97 & $\begin{array}{c}13.8 \\
8\end{array}$ \\
\hline $\begin{array}{l}\text { WAV1\% } \\
25^{\circ} \mathrm{C}\end{array}$ & 0.95 & 3.10 & 1.75 & 5.75 & 0.81 & 5.63 & 5.37 & 4.43 & $\begin{array}{c}10.9 \\
3\end{array}$ & 0.79 & 6.83 \\
\hline $\begin{array}{l}\text { WAV2\% } \\
25^{\circ} \mathrm{C}\end{array}$ & 1.75 & 4.50 & 1.85 & 6.07 & 1.40 & 5.89 & 6.00 & 5.76 & $\begin{array}{c}22.5 \\
1\end{array}$ & 0.98 & $\begin{array}{c}14.6 \\
0\end{array}$ \\
\hline
\end{tabular}




\begin{tabular}{lccccccccccc}
\hline $\begin{array}{l}\text { WAV3\% } \\
\mathbf{2 5} \mathbf{C}\end{array}$ & 1.58 & 5.20 & 2.36 & 7.74 & 0.78 & 7.48 & 7.44 & 6.67 & $\begin{array}{c}22.6 \\
9\end{array}$ & 0.89 & $\begin{array}{c}17.4 \\
5\end{array}$ \\
\hline $\begin{array}{l}\text { KNU1\% } \\
\mathbf{2 5} \mathbf{C}\end{array}$ & 1.31 & 4.30 & 1.48 & 4.87 & 0.43 & 4.60 & 2.32 & 1.36 & 4.10 & 0.50 & 2.84 \\
\hline $\begin{array}{l}\text { KNU2\% } \\
\mathbf{2 5} \mathbf{C}\end{array}$ & 2.19 & 7.20 & 2.76 & 9.05 & 0.67 & 8.87 & 8.55 & 7.86 & $\begin{array}{c}32.0 \\
4\end{array}$ & 0.88 & $\begin{array}{c}26.9 \\
7\end{array}$ \\
\hline $\begin{array}{l}\text { KNU3\% } \\
\mathbf{2 5} \mathbf{C}\end{array}$ & 2.59 & 8.50 & 3.60 & 11.84 & 0.97 & 11.73 & 10.83 & 9.51 & $\begin{array}{c}39.5 \\
6\end{array}$ & 0.81 & $\begin{array}{c}37.7 \\
6\end{array}$ \\
\hline
\end{tabular}

Table 6 - Experimental results of peak and post-peak parameters for the monotonic three-point bending tests fired sample at $600^{\circ} \mathrm{C}$.

\begin{tabular}{|c|c|c|c|c|c|c|c|c|c|c|c|}
\hline Mix & $\begin{array}{l}P_{\text {lop }} \\
\text { (kN) }\end{array}$ & $\begin{array}{c}\sigma_{\text {lop }} \\
(\mathrm{MPa})\end{array}$ & $\begin{array}{c}\mathrm{Pu} \\
(\mathrm{kN})\end{array}$ & $\begin{array}{l}\text { MOR } \\
\text { (MPa) }\end{array}$ & $\begin{array}{c}\text { CMOD } \\
\text { MOR } \\
(\mathrm{mm})\end{array}$ & $\begin{array}{c}f_{R 1} \\
(\mathrm{MPa})\end{array}$ & $\begin{array}{c}f_{\mathrm{R} 2} \\
(\mathrm{MPa})\end{array}$ & $\begin{array}{c}f_{\mathrm{R3}} \\
(\mathrm{MPa})\end{array}$ & $\begin{array}{l}T_{2.0} \\
(J)\end{array}$ & $\begin{array}{c}\mathbf{f}_{\mathrm{R} 3} / \\
\mathbf{f}_{\mathrm{R} 1}\end{array}$ & $\begin{array}{l}G_{F} \\
(J)\end{array}$ \\
\hline $\begin{array}{l}\text { Matrix } \\
600^{\circ} \mathrm{C}\end{array}$ & 0.73 & 2.38 & - & - & - & - & - & - & 0.21 & - & 0.16 \\
\hline $\begin{array}{l}\text { STR1\% } \\
600^{\circ} \mathrm{C}\end{array}$ & 0.85 & 2.80 & 1.11 & 3.65 & 0.38 & 3.48 & 2.72 & 2.54 & 5.83 & 0.73 & 4.77 \\
\hline $\begin{array}{l}\text { STR2\% } \\
600^{\circ} \mathrm{C}\end{array}$ & 0.94 & 3.10 & 1.23 & 4.02 & 0.70 & 3.91 & 3.69 & 3.62 & 7.26 & 0.93 & 4.86 \\
\hline $\begin{array}{l}\text { STR3\% } \\
600^{\circ} \mathrm{C}\end{array}$ & 1.00 & 3.30 & 1.29 & 4.24 & 0.55 & 4.19 & 4.13 & 4.18 & 8.17 & 1.00 & 6.15 \\
\hline $\begin{array}{l}\text { WAV1\% } \\
600^{\circ} \mathrm{C}\end{array}$ & 0.67 & 1.50 & 0.89 & 2.92 & 0.48 & 2.91 & 2.38 & 2.13 & 5.38 & 0.73 & 3.24 \\
\hline $\begin{array}{l}\text { WAV2\% } \\
600^{\circ} \mathrm{C}\end{array}$ & 0.70 & 2.10 & 1.11 & 3.67 & 0.41 & 3.57 & 2.58 & 2.58 & 5.05 & 0.72 & 3.88 \\
\hline $\begin{array}{l}\text { WAV3\% } \\
600^{\circ} \mathrm{C}\end{array}$ & 0.82 & 2.70 & 1.47 & 4.82 & 1.16 & 4.35 & 4.72 & 4.57 & 8.32 & 1,05 & 3,70 \\
\hline $\begin{array}{l}\text { KNU1\% } \\
600^{\circ} \mathrm{C}\end{array}$ & 0.15 & 0.50 & 0.35 & 1.16 & 0.43 & 1.13 & 1.03 & 1.10 & 1.82 & 0.97 & 1.40 \\
\hline $\begin{array}{l}\text { KNU2\% } \\
600^{\circ} \mathrm{C}\end{array}$ & 0.58 & 1.90 & 0.88 & 2.89 & 0.36 & 2.81 & 2.07 & 2.07 & 4.39 & 0.74 & 3.51 \\
\hline $\begin{array}{l}\text { KNU3\% } \\
600^{\circ} \mathrm{C}\end{array}$ & 1.03 & 3.40 & 1.86 & 6.11 & 1.01 & 5.77 & 5.89 & 5.58 & $\begin{array}{c}11.1 \\
4\end{array}$ & 0.97 & 6.09 \\
\hline
\end{tabular}

Table 7 - Experimental results of peak and post-peak parameters for the monotonic three-point bending tests fired sample at $1000^{\circ} \mathrm{C}$.

\begin{tabular}{|c|c|c|c|c|c|c|c|c|c|c|c|}
\hline Mix & $\begin{array}{l}P_{\text {lop }} \\
\text { (kN) }\end{array}$ & $\begin{array}{c}\sigma_{\text {lop }} \\
(\mathrm{MPa})\end{array}$ & $\begin{array}{c}\mathrm{Pu} \\
(\mathrm{kN})\end{array}$ & $\begin{array}{c}\text { MOR } \\
\text { (MPa) }\end{array}$ & $\begin{array}{c}\text { CMOD } \\
\text { MOR } \\
(\mathrm{mm})\end{array}$ & $\begin{array}{c}f_{R 1} \\
(\mathrm{MPa})\end{array}$ & $\begin{array}{c}\mathbf{f}_{\mathrm{R} 2} \\
(\mathrm{MPa})\end{array}$ & $\begin{array}{c}f_{\mathrm{R} 3} \\
(\mathrm{MPa})\end{array}$ & $\begin{array}{l}T_{2.0} \\
(J)\end{array}$ & $\begin{array}{c}\mathbf{f}_{\mathrm{R} 3} / \\
\mathbf{f}_{\mathrm{R} 1}\end{array}$ & $\begin{array}{l}G_{F} \\
\text { (J) }\end{array}$ \\
\hline $\begin{array}{l}\text { Matrix } \\
1000^{\circ} \mathrm{C}\end{array}$ & 0.39 & 1.30 & - & - & - & - & - & - & 0.15 & - & 0.12 \\
\hline $\begin{array}{l}\text { STR1\% } \\
1000^{\circ} \mathrm{C}\end{array}$ & 0.27 & 0.90 & 0.32 & 1.05 & 0.08 & 0.59 & 0.34 & 0.34 & 0.75 & 0.57 & 0.70 \\
\hline $\begin{array}{l}\text { STR2\% } \\
1000^{\circ} \mathrm{C}\end{array}$ & 0.38 & 1.25 & 0.60 & 1.97 & 0.71 & 1.89 & 1.81 & 1.75 & 4.84 & 0.93 & 3.73 \\
\hline $\begin{array}{l}\text { STR3\% } \\
1000^{\circ} \mathrm{C}\end{array}$ & 0.45 & 1.50 & 0.65 & 2.10 & 0.35 & 2.05 & 1.76 & 1.68 & 4.85 & 0.82 & 4.30 \\
\hline $\begin{array}{l}\text { WAV1\% } \\
1000^{\circ} \mathrm{C}\end{array}$ & 0.24 & 0.80 & 0.36 & 1.18 & 0.30 & 1.09 & 0.89 & 0.89 & 1.30 & 0.82 & 1.00 \\
\hline $\begin{array}{l}\text { WAV2\% } \\
1000^{\circ} \mathrm{C}\end{array}$ & 0.48 & 1.60 & 0.61 & 2.00 & 0.30 & 1.92 & 1.75 & 1.75 & 2.34 & 0.92 & 1.72 \\
\hline
\end{tabular}




\begin{tabular}{|c|c|c|c|c|c|c|c|c|c|c|c|}
\hline $\begin{array}{l}\text { WAV3\% } \\
1000^{\circ} \mathrm{C}\end{array}$ & 0.70 & 2.30 & 0.90 & 2.94 & 0.40 & 2.90 & 2.38 & 2.13 & 5.23 & 0.74 & 4.22 \\
\hline $\begin{array}{l}\text { KNU1\% } \\
1000^{\circ} \mathrm{C}\end{array}$ & 0.39 & 1.30 & 0.42 & 1.39 & 0.30 & 1.33 & 1.18 & 1.18 & 1.50 & 0.88 & 1.16 \\
\hline $\begin{array}{l}\mathrm{KNU} 2 \% \\
1000^{\circ} \mathrm{C}\end{array}$ & 0.64 & 2.10 & 0.83 & 2.72 & 0.30 & 2.60 & 2.19 & 2.19 & 3.59 & 0.83 & 2.93 \\
\hline $\begin{array}{l}\text { KNU3\% } \\
1000^{\circ} \mathrm{C}\end{array}$ & 0.79 & 2.60 & 1.17 & 3.86 & 0.50 & 3.85 & 3.41 & 3.11 & 4.97 & 0.81 & 3.28 \\
\hline
\end{tabular}

For structural applications the material classification is based on the postcracking residual strength, for service $\left(f_{R 1}\right)$ and ultimate $\left(f_{R 3}\right)$ conditions of refractory concretes reinforced with fibers, FRRC, according to the fib Model Code are summarized in the following Table 8.

Table 8 - Classification of fiber reinforced refractory concrete in accordance with the fib Model Code recommendations.

\begin{tabular}{|c|c|c|c|c|c|c|c|c|}
\hline $\begin{array}{l}\text { Mix } \\
25^{\circ} \mathrm{C}\end{array}$ & $\begin{array}{c}f_{R 3} / \\
f_{R 1}\end{array}$ & Class & $\begin{array}{l}\text { Mix } \\
600^{\circ} \mathrm{C}\end{array}$ & $\begin{array}{c}\mathbf{f}_{\mathrm{R} 3} / \\
\mathbf{f}_{\mathrm{R} 1}\end{array}$ & Class & $\begin{array}{c}\text { Mix } \\
1000^{\circ} \mathrm{C}\end{array}$ & $f_{R 3} / f_{R 1}$ & Class \\
\hline $\begin{array}{l}\text { STR1\% } \\
25^{\circ} \mathrm{C}\end{array}$ & 0.59 & $a$ & $\begin{array}{l}\text { STR1\% } \\
600^{\circ} \mathrm{C}\end{array}$ & 0.73 & $b$ & $\begin{array}{l}\text { STR1\% } \\
1000^{\circ} \mathrm{C}\end{array}$ & 0.57 & a \\
\hline $\begin{array}{l}\text { STR } 2 \% \\
25^{\circ} \mathrm{C}\end{array}$ & 0.51 & $a$ & $\begin{array}{l}\text { STR2\% } \\
600^{\circ} \mathrm{C}\end{array}$ & 0.93 & c & $\begin{array}{l}\text { STR2\% } \\
1000^{\circ} \mathrm{C}\end{array}$ & 0.93 & c \\
\hline $\begin{array}{c}\text { STR3\% } \\
25^{\circ} \mathrm{C}\end{array}$ & 0.97 & c & $\begin{array}{l}\text { STR3\% } \\
600^{\circ} \mathrm{C}\end{array}$ & 1.00 & c & $\begin{array}{l}\text { STR3\% } \\
1000^{\circ} \mathrm{C}\end{array}$ & 0.82 & $b$ \\
\hline $\begin{array}{l}\text { WAV1\% } \\
25^{\circ} \mathrm{C}\end{array}$ & 0.79 & $b$ & $\begin{array}{l}\text { WAV1\% } \\
600^{\circ} \mathrm{C}\end{array}$ & 0.73 & $b$ & $\begin{array}{l}\text { WAV } 1 \% \\
1000^{\circ} \mathrm{C}\end{array}$ & 0.82 & $b$ \\
\hline $\begin{array}{c}\text { WAV } 2 \% \\
25^{\circ} \mathrm{C}\end{array}$ & 0.98 & c & $\begin{array}{c}\text { WAV } 2 \% \\
600^{\circ} \mathrm{C}\end{array}$ & 0.72 & $b$ & $\begin{array}{l}\text { WAV } 2 \% \\
1000^{\circ} \mathrm{C}\end{array}$ & 0.92 & c \\
\hline $\begin{array}{c}\text { WAV } 3 \% \\
25^{\circ} \mathrm{C}\end{array}$ & 0.89 & $b$ & $\begin{array}{c}\text { WAV } 3 \% \\
600^{\circ} \mathrm{C}\end{array}$ & 1,05 & c & $\begin{array}{l}\text { WAV } 3 \% \\
1000^{\circ} \mathrm{C}\end{array}$ & 0.74 & $b$ \\
\hline $\begin{array}{c}\mathrm{KNU} 1 \% \\
25^{\circ} \mathrm{C}\end{array}$ & 0.50 & a & $\begin{array}{c}\mathrm{KNU} 1 \% \\
600^{\circ} \mathrm{C}\end{array}$ & 0.97 & c & $\begin{array}{l}\mathrm{KNU} 1 \% \\
1000^{\circ} \mathrm{C}\end{array}$ & 0.88 & $b$ \\
\hline $\begin{array}{c}\mathrm{KNU} 2 \% \\
25^{\circ} \mathrm{C}\end{array}$ & 0.88 & $b$ & $\begin{array}{c}\mathrm{KNU} 2 \% \\
600^{\circ} \mathrm{C}\end{array}$ & 0.74 & $b$ & $\begin{array}{l}\text { KNU2\% } \\
1000^{\circ} \mathrm{C}\end{array}$ & 0.83 & $b$ \\
\hline $\begin{array}{c}\mathrm{KNU} 3 \% \\
25^{\circ} \mathrm{C}\end{array}$ & 0.81 & $b$ & $\begin{array}{c}\mathrm{KNU} 3 \% \\
600^{\circ} \mathrm{C}\end{array}$ & 0.97 & c & $\begin{array}{l}\mathrm{KNU} 3 \% \\
1000^{\circ} \mathrm{C}\end{array}$ & 0.81 & $b$ \\
\hline
\end{tabular}

\subsection{Pullout at different temperatures}

The pullout fiber test results clearly illustrate the difference in behavior between the different fibers shapes, especially in the peak force value reached and the shape of the force-displacement curve after the peak load. Figure 9 presents the 
representative curve of pullout experimental for straight, wavy and knurled fiber embedment $\left(\mathrm{L}_{\mathrm{f}}=12.5 \mathrm{~mm}\right)$ in refractory matrix, after specimens exposed at different temperatures $\left(25,600,900,1000\right.$ and $\left.1100^{\circ} \mathrm{C}\right)$. Figure 9a presents the pullout behavior of the straight fiber after the specimens at different temperatures, all curves indicated a pronounced drop after peak load. This is linked to a strainsoftening response [10]. Figure $9 \mathrm{~b}$ shows the pullout results for the wavy fiber, shows a post-peak curve with softening for unfired sample $\left(25^{\circ} \mathrm{C}\right)$. While for the fired samples the sudden drop occurs, due to the fiber rupture and therefore the total fiber pullout does not occur. In the case of pullout curves for the knurled fiber in Figura 9c reach higher peak load values compared to straight and wavy fibers at all tested temperatures, except for $1100^{\circ} \mathrm{C}$ because at this temperature the knurled fiber was more affected by the firing process (in the non-embedded part). The curves indicate a peak interrupted by fiber rupture, the fiber could not be pulled out. The use of $2 \%$ of knurled fibers composites at $25^{\circ} \mathrm{C}$ promoted higher values of residual flexural strength, MOR and toughness when compared with $2 \%$ of straight and wavy fibers, including $3 \%$. The higher values of the mechanical parameters for the use of knurled fiber is associated with the fiber anchorage in the matrix. A microscopic image details the surface of the knurled fiber in the Figure 10. The anchorage effect given by the knurled surface plays an important role in increasing the pullout load. While the straight and wavy fiber presents a peak pullout load of $140 \mathrm{~N}$ and $160 \mathrm{~N}$ respectively, the knurled fiber reaches its peak at $185 \mathrm{~N}$. These load values were obtained for unfired samples $\left(25^{\circ} \mathrm{C}\right)$. This significant difference is maintained for the burning temperatures considered. Therefore, the use of the knurled as mechanical anchoring considerably improves the post-peak strength of the fiber reinforced composite. 


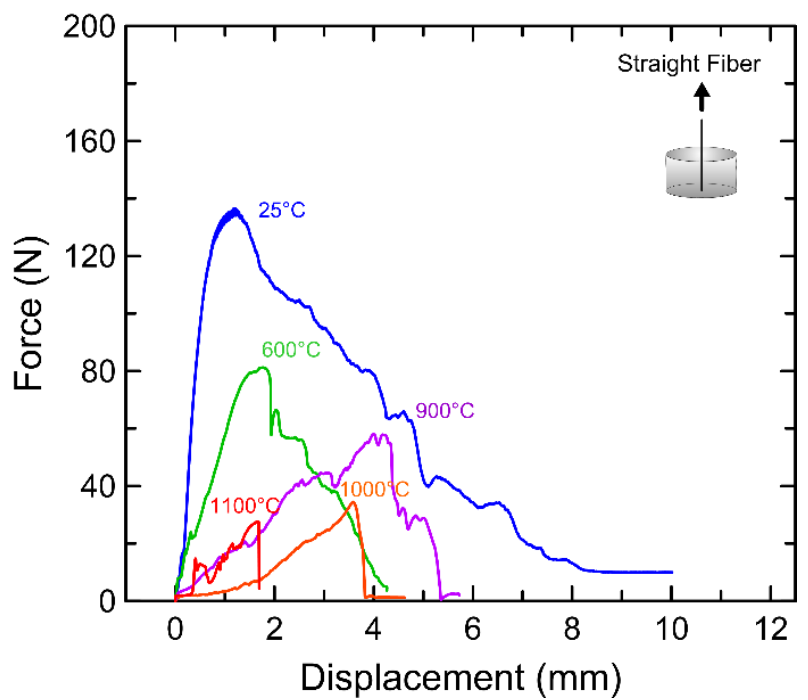

a)

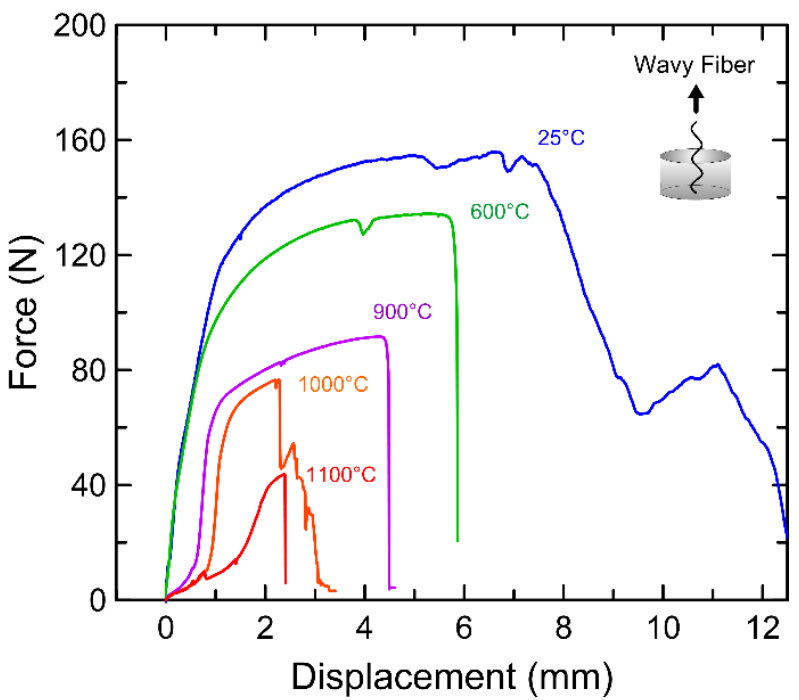

b)

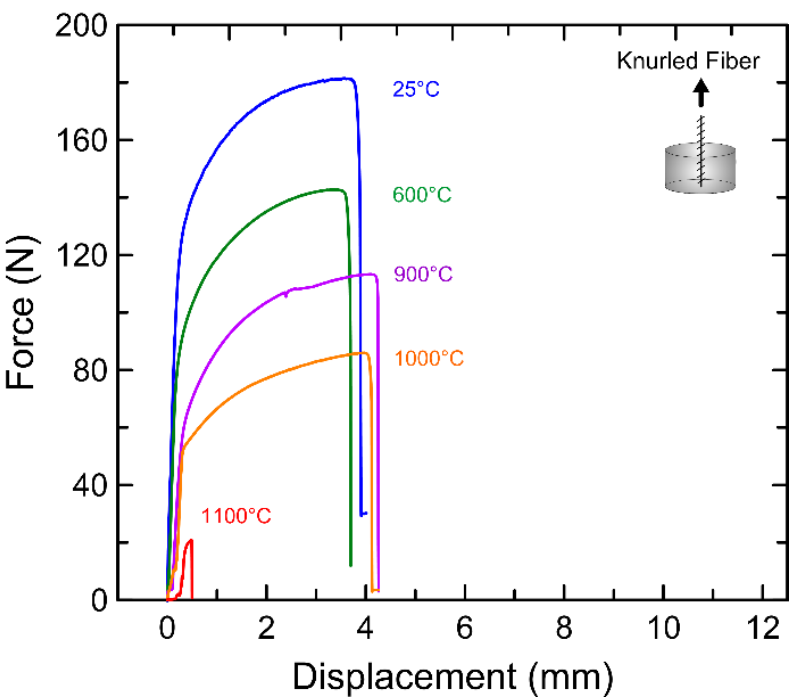

c)

Figure 9 - Pullout results at different temperatures $25,600,900,1000$ and $1100^{\circ} \mathrm{C}$ a) straight fiber b) wavy fiber and c) knurled fiber d) microscopic image of knurled fiber. 

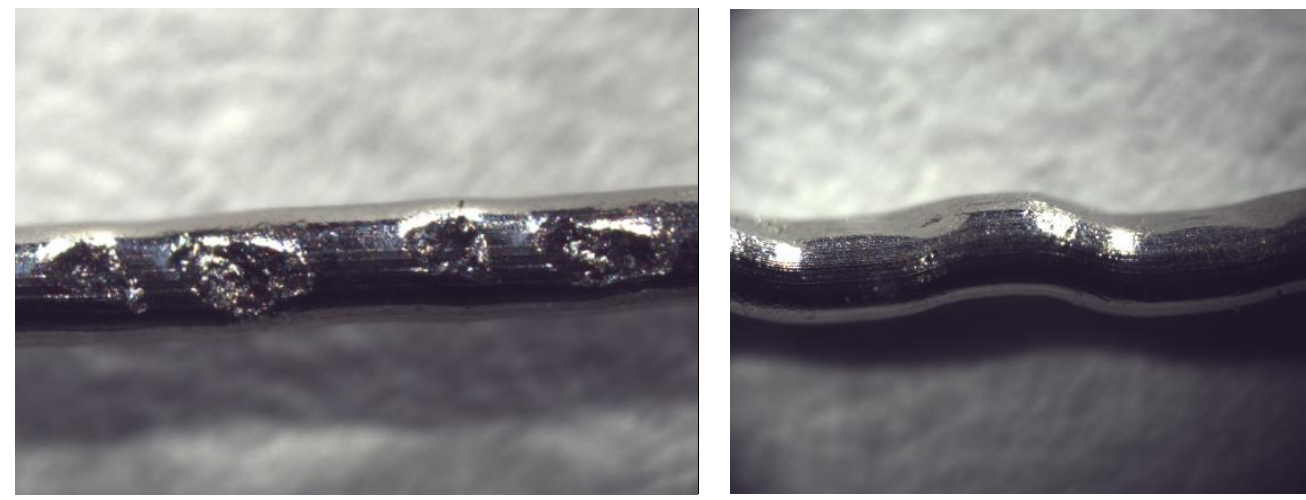

Figure 10 - Microscopic image of the knurled fiber surface

\subsection{Direct tensile test and compression test}

The results from the direct tensile test of fiber reinforced refractory concrete for specimens used 2\% stainless steel knurled fiber (KNU2\%) are shown in Figure $11 \mathrm{a}$ along with the results of the compression tests on the material matrix. The peak tensile stress value reached 5.20 MPa for the reinforced composites not fired and after that it decreases steep softening slope. However, the increase in the tensile strength when compared to the matrix $(4.10 \mathrm{MPa})$ was $27 \%$. The compression tests (Figure 11b) for the same fiber reinforced composites (KNU2\%) were carried out at different temperatures $\left(25,600\right.$ and $\left.1000^{\circ} \mathrm{C}\right)$. As expected a quasi-brittle behavior was observed for room temperature $\left(25^{\circ} \mathrm{C}\right)$ whereas a elasto-viscoplastic behavior was observed for the fired specimens in high temperatures (e.g., $\left.1000^{\circ} \mathrm{C}\right)[11]$. Compressive strength values decreased with increasing temperature. For the unfired $\left(25^{\circ}\right)$ specimen it was $59 \mathrm{MPa}$ and for the fired $\left(1000^{\circ} \mathrm{C}\right)$ specimen the compressive stress $(20 \mathrm{MPa}$ ) reduced in $70 \%$. The reinforced composite when compared with the matrix also showed an increase in ductility, but the peak compressive strength value showed little difference. 
a)

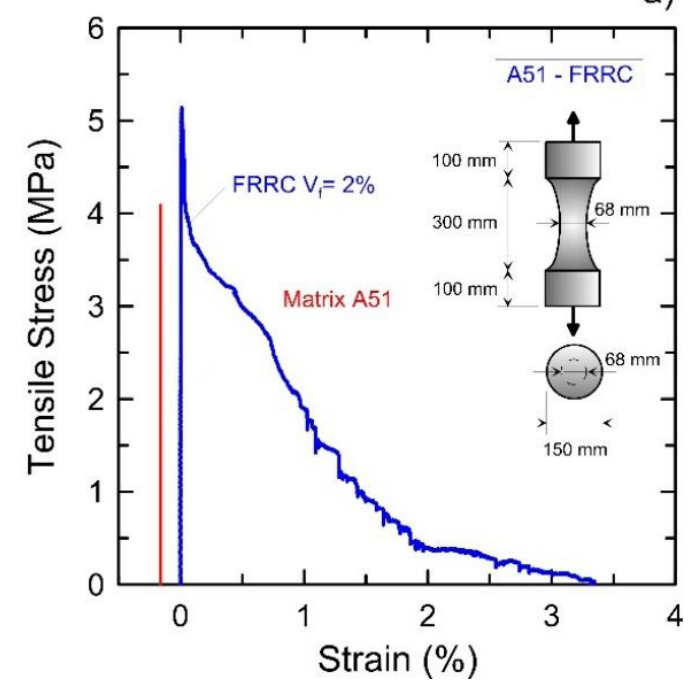

b)

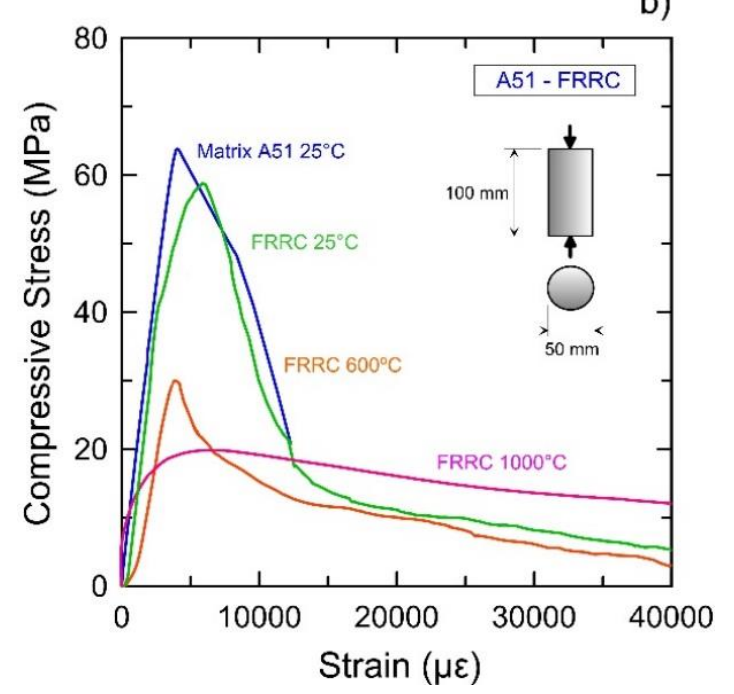

Figure 11 - Influence of the stainless steel fiber reinforcement in the a) direct tensile test and b) compression test of the refractory concretes.

\subsection{Cyclic test}

The loading/unloading cyclic tests were performed for the monotonic threepoint bending tests. Figure 12 presents the cyclic tests mean curves for KNU2\% composite specimens unfired at $25^{\circ} \mathrm{C}$ and fired at 600 and $1000^{\circ} \mathrm{C}$. This test allows the observation of the deformation capacity of the composite when the mechanical damage develops in addition to the thermal damage caused by firing. The main fracture parameters were calculated according on RILEM 89-FMT [12]. The MOR apparent modulus of rupture was calculated using Eq. (1).

$$
M O R=\frac{3 P_{\text {máx }} S}{2 t\left(b-a_{0}\right)^{2}}
$$

Where $P_{\text {máx }}$ is the maximum flexural load; $S$ is the beam span, $t$ and $b$, are, respectively the thickness and depth of tested prism specimen, $a_{0}$ is the notch length, and $\left(b-a_{0}\right)$ is the uncracked depth. The elastic modulus E was calculated using Eq. (2) and Eq. (3):

$$
E=\frac{6 S a_{0} V(\alpha)}{C_{i} b^{2} t}
$$




$$
V(\alpha)=0.76-2.28 \alpha+3.87 \alpha^{2}-2.04 \alpha^{3}+\frac{0.66}{(1-\alpha)^{2}}
$$

Where $\mathrm{S}$ is the beam span, $a_{0}$ is the notch length, $t$ and $b$ are the thickness and depth respectively, $\alpha$ is the normalized notch length defined as $a_{0} / b$, and $C_{i}$ is the initial compliance of specimen. The specimen dimensions are illustrated in Figure 12. The critical effective crack length $\left(a_{c}\right)$ is determined from the elastic modulus $E$ calculated from Eq. (2) and the unloading compliance $\mathrm{C}_{\mathrm{u}}$ measured at the maximum load using a numerical solution of Eq. (2) and (4).

$$
a_{c}=\frac{E C_{u} b^{2} t}{6 S V(\alpha)}
$$

The critical stress intensity factor $\left(\mathrm{K}_{\mathrm{IC}}\right)$, critical crack tip opening displacement $\left(\mathrm{CTOD}_{\mathrm{C}}\right)$ and critical intrinsic fracture toughness $\left(\mathrm{G}_{\mathrm{IC}}\right)$ were calculated using the Eqs. (5)-(8):

$$
\begin{gathered}
K_{I C}=\frac{S \sqrt{\left(\pi a_{c}\right)} F\left(\alpha_{c}\right)}{2 b^{2} t} \\
F\left(\alpha_{c}\right)=\frac{1.99-\alpha_{c}\left(1-\alpha_{c}\right)\left(2.15-3.93 \alpha_{c}+2.7 \alpha_{c}^{2}\right.}{\sqrt{\pi}\left(1+2 \alpha_{c}\right)\left(1-\alpha_{c}\right)^{3 / 2}} \\
C T O D_{C}=\frac{6 P_{\text {máx } S a_{c} V\left(\alpha_{c}\right)} E b^{2} t}{\left[\left(1-\beta_{0}\right)^{2}+\left(1.081-1.149 \alpha_{c}\right)\left(\beta_{0}-\beta_{0}^{2}\right]^{1 / 2}\right.} \\
G_{I C}=\frac{K_{I C}^{2}}{E}
\end{gathered}
$$

Where $\alpha_{c}=a_{c} / b$ and $\beta_{0}=a_{c} / a_{0}$

The cyclic fracture parameters for the analyzed refractory composites are shown in the Table 9. The various parameters calculated from cyclic tests indicated a certain trend in the degradation of the refractory composites with increasing 
temperature. As expected for the monotonic bending results, the values of MOR decrease as the temperature increases to $1000^{\circ} \mathrm{C}$. When compared with the results for unfired specimens $\left(25^{\circ} \mathrm{C}\right)$ the value is reduced by $25 \%$ for specimen fired at $1000^{\circ} \mathrm{C}$. It was also observed that the modulus of elasticity variation in function of the temperature was similar to that obtained in the compression (Figure 11) tests of the composites $22.10 \mathrm{GPa}, 11.06 \mathrm{GPa}$ and $4.90 \mathrm{GPa}$ (Table 9) for 25, 600 and $1000^{\circ} \mathrm{C}$. However, no significant variation with temperature is obtained for the critical crack length which determines the total length of crack extension, from which the crack growth becomes unstable $[13,14]$. This result can be attributed to an effective knurled fiber bridge at different temperatures.

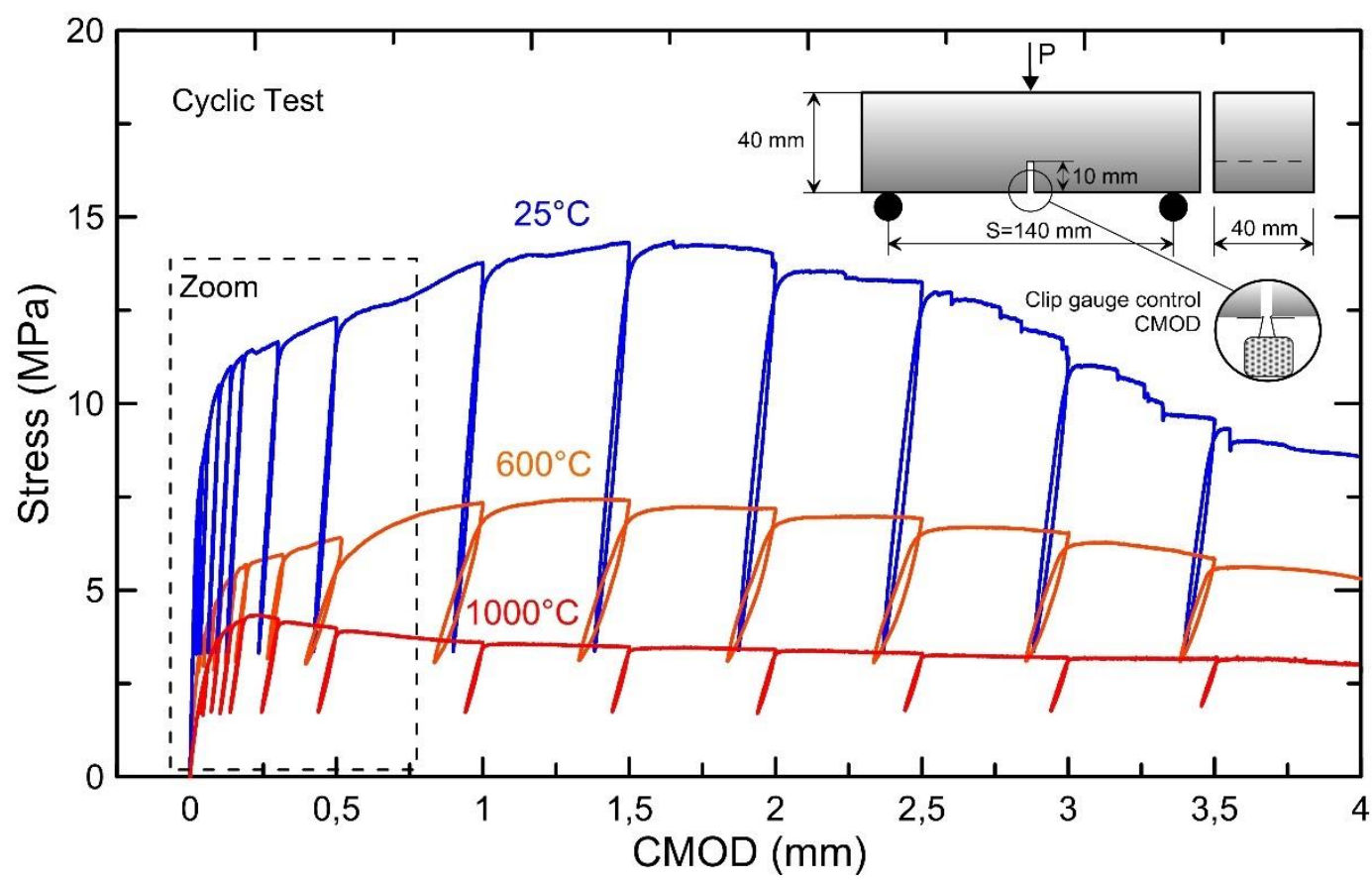




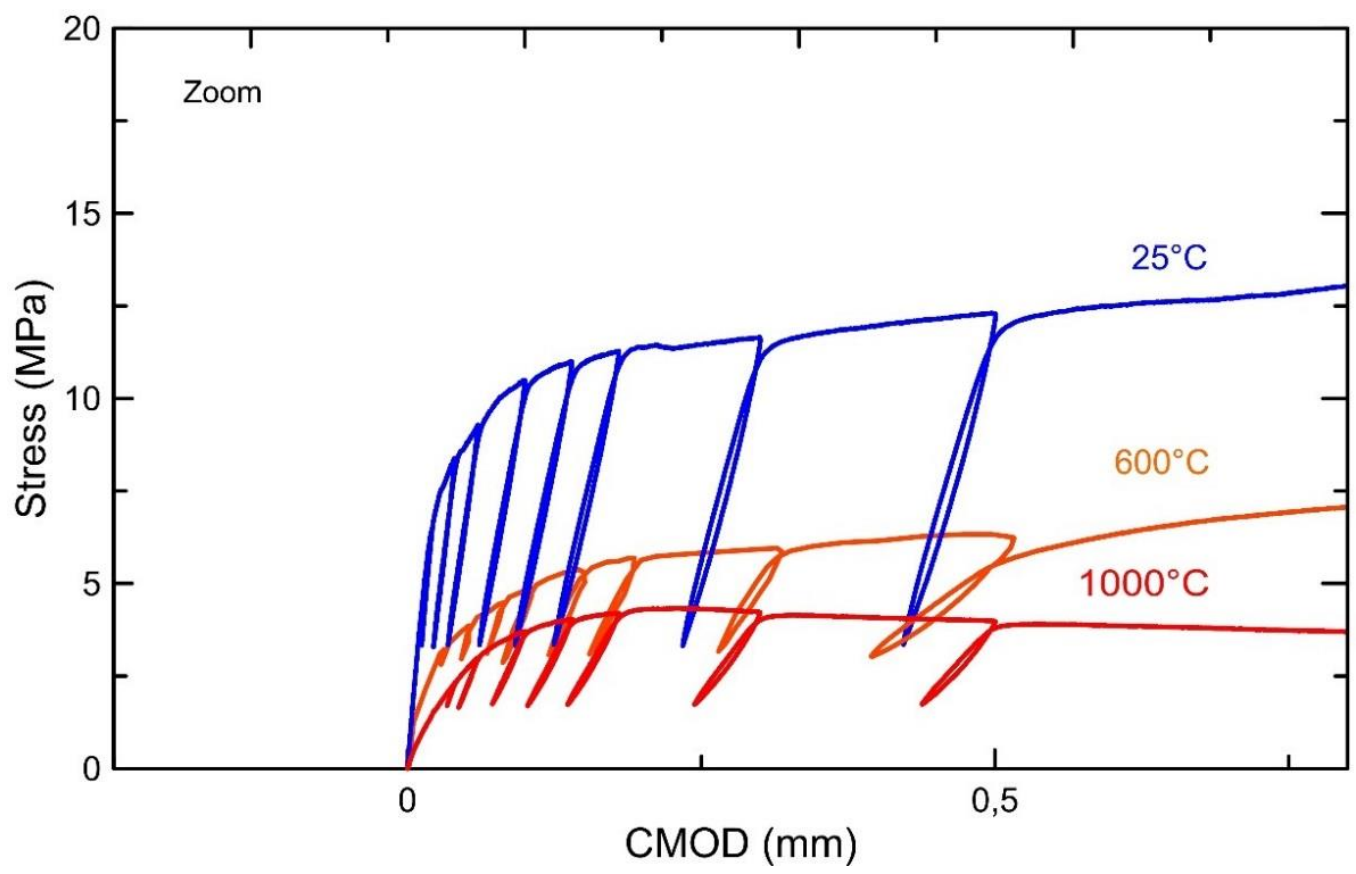

Figure 12 - Results from cyclic three-point bending tests at different temperatures 25,600 and $1000^{\circ} \mathrm{C}$ of the $2 \%$ SFRRC and zoom up to CMOD range $1 \mathrm{~mm}$.

Table 9 - Results of cyclic fracture parameters for the refractory composites with $2 \%$ of stainless steel fiber at 25,600 and $1000^{\circ} \mathrm{C}$.

\begin{tabular}{|c|c|c|c|}
\hline \multirow{2}{*}{ Parameters } & \multicolumn{3}{|c|}{ Composites } \\
\hline & $\mathrm{KNU} 2 \% 25^{\circ} \mathrm{C}$ & KNU2\% $600^{\circ} \mathrm{C}$ & $\mathrm{KNU} 2 \% 1000^{\circ} \mathrm{C}$ \\
\hline Apparent MOR (MPa) & 13.18 & 7.10 & 4.50 \\
\hline Elastic Modulus (GPa) & 22.10 & 11.06 & 4.90 \\
\hline Critical Crack Length (mm) & 18.60 & 20.96 & 17.20 \\
\hline Critical SIF (MPa.mm 0.5 ) & 134.60 & 66.80 & 41.38 \\
\hline Critical CTOD $(\mu \mathrm{m})$ & 61.23 & 132.16 & 84.56 \\
\hline Critical Strain Energy Release Rate $(\mathrm{N} / \mathrm{m})$ & 725.12 & 614.97 & 350.70 \\
\hline
\end{tabular}

The resistance to crack growth can be represented by the strain release, $G_{R}$. This rate of energy released by the crack extension was calculated from the change of stored elastic energy in the specimen through Eq. (9), by using the derivatives of fitted compliance and inelastic CMOD curves [12]. 


$$
G_{R}=\frac{P^{2}}{2 t} \frac{d C_{U}}{d a}+\frac{P}{2 t} \frac{d \delta_{i n}}{d a}
$$

Where $P$ is the flexural load, $C_{U}$ is the unloading compliance of prism, $t$ is the thickness of specimen and $a$ is the effective crack length, $\delta_{\text {in }}$ is the inelastic CMOD. The Fracture toughness, $\mathrm{G}_{\mathrm{R}}$ can also be associated to stress intensity factor, $\mathrm{K}_{\mathrm{R}}$ during crack propagation using Eq. (10).

$$
K_{R}=\sqrt{E G_{R}}
$$

Figure 13 illustrated the R-Curves, i.e., the crack resistances results in function to the total crack length $(\Delta \mathrm{a})$ of the specimen for the cyclic tests analyzed, were considered 8 cycles for the analyses within the CMOD range up to $1 \mathrm{~mm}$. From these R-Curves it is possible to analyze the difference in the resistance against crack propagation at different temperatures. For the refractory composites exposed to $25^{\circ} \mathrm{C}$ was obtained a higher $\mathrm{G}_{\mathrm{R}}$ value of $13.10 \mathrm{~N} / \mathrm{mm}$ at a total crack length of $9.50 \mathrm{~mm}$. The composite fired at $600^{\circ} \mathrm{C}$ reached a $11.80 \mathrm{~N} / \mathrm{mm}$ with a crack length of $13 \mathrm{~mm}$ and at $1000^{\circ} \mathrm{C}$ the values obtained were $5.20 \mathrm{~N} / \mathrm{mm}$ with a crack length of $9.60 \mathrm{~mm}$. However, the composite fired at $1000^{\circ} \mathrm{C}$ presented an increase in crack growth resistance for smaller values of length $(<6.30 \mathrm{~mm})$ when compared to curves of 25 and $600^{\circ} \mathrm{C}$. Moreover, the R-Curve of $1000^{\circ} \mathrm{C}$ showed a more resistant R-curve to cracks extension than the specimen at the temperature of $600^{\circ} \mathrm{C}$, specifically for longer crack lengths $(6.30 \mathrm{~mm}<\Delta \mathrm{a}<10 \mathrm{~mm})$. This indicates a suitable crack propagation resistance of the material at elevated temperatures. 


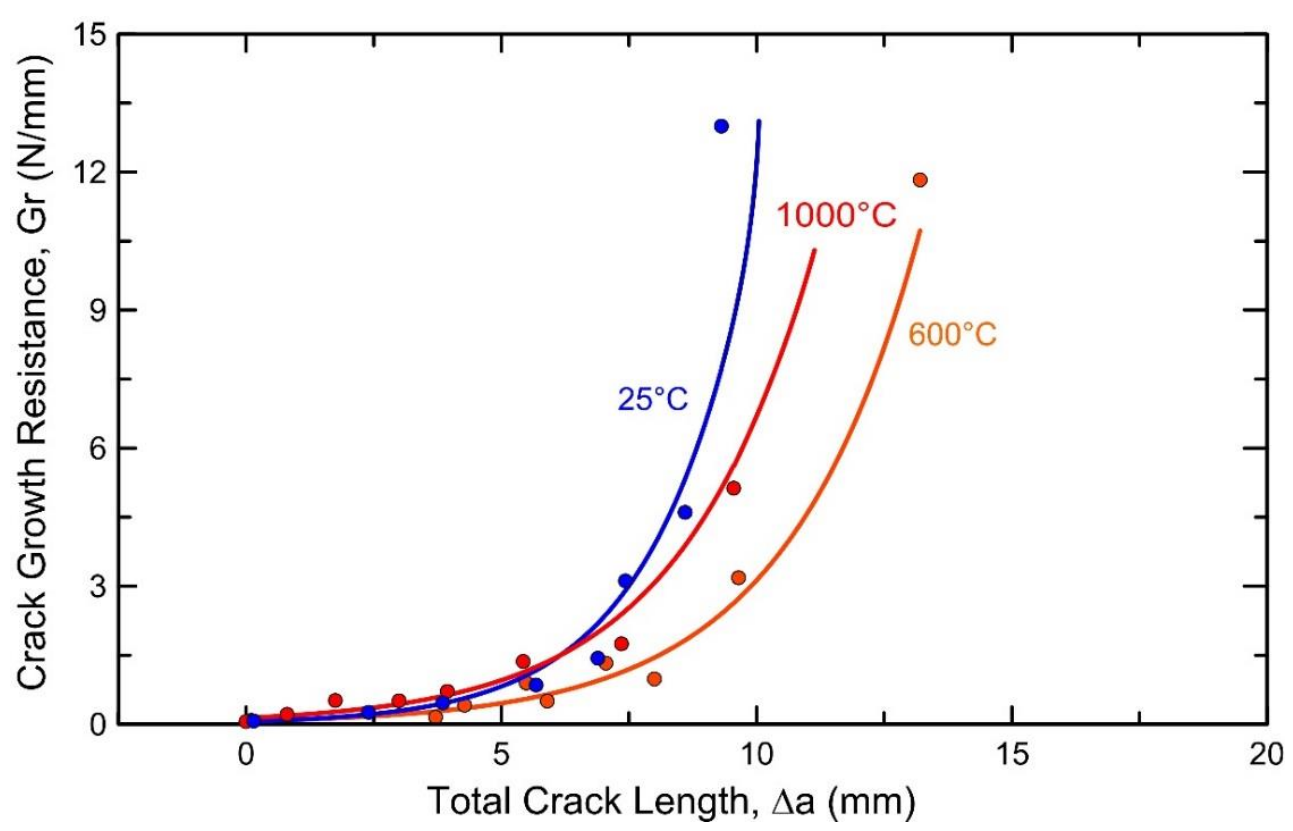

Figure 13 - R- Curve for the refractory composites KNU2\% at 25, 600 and $1000^{\circ} \mathrm{C}$

\subsection{Numerical Simulation}

\subsubsection{Round Panel Tests}

The goal of FEM numerical simulations of the round panel tests is to validate the material model of the stainless steel fiber reinforced refractory concrete. Moreover, through this test method it was possible to obtain the energy absorption of the FRRC composites $[15,16]$.

The mechanical characterization obtained in tensile direct test, compression test and three-point bending tests for composite KNU2\% was used for the development of the structural models in ABAQUS at different temperatures (25, 600 and $1000^{\circ} \mathrm{C}$ ). The experimental test was performed according ASTM C155004 [17] for the round panel made with unfired composite $\mathrm{KNU} 2 \%$ at $25^{\circ} \mathrm{C}$,. Figure 14a provides the crack opening measurements obtained using a three LVDTs system along with the cracking pattern. 
A nonlinear simulation of the mechanical behavior of round panel specimens was performed using a concrete damage plasticity model [18]. A mesh convergence study was carried out and the mesh converged with 10150 S4R (4 node with reduced integration) shell elements with a tolerance of $3 \%$ in the displacement at center node between this and the next refinement of the mesh. The shell elements are employed in structures in which the thickness is approximately $1 / 10$ the overall size. The three supports were simulated by fixing the three nodes separated by $120^{\circ}$ similarly to the test setup, i.e., all degrees of freedoms related to displacement were restricted allowing rotation as this accurately reflects experimental setup, which counts a kneecap in each support.

The load-displacement curves at the central node of the round panel were obtained and compared with the experimental curve as shown in Figure 14a. The FEM simulation results for the unfired specimen at $25^{\circ} \mathrm{C}$ showed a good correlation with the experimental results, i.e., a difference of about $15 \%$ between the peak load from the measurement and the simulation. This was considered reasonably accurate, and therefore, it validates the developed constitutive material model.

Figure $14 \mathrm{~b}$ shows the stress and displacement fields obtained from the finite element simulation after the initiation of the first crack. The stress field at first crack indicates a maximum stress of $4.50 \mathrm{MPa}$ in the zone where the macrocracks occur. The displacement at the center of the round panel and the corresponding load at the first crack obtained by the simulation were: $0.418 \mathrm{~mm}$ and $21 \mathrm{kN}$, respectively. The values obtained experimentally were $0.450 \mathrm{~mm}$ and $20 \mathrm{kN}$. The difference between these results was around $7 \%$. These results validate the developed numerical model of the round panel test. Based on this, the round panel test was simulated for the higher temperatures $\left(600\right.$ and $\left.1000^{\circ} \mathrm{C}\right)$ using the constitutive material relationship 
obtained in the previous compression tests and bending tests (Figura 15). The data used for the constitutive model of the FRRCs and the parameters of concrete damage plasticity model (CDP) used in the simulations are summarized in Table 10 and Table 11. The results are shown in Figure 15. A comparison with the results obtained for the unfired round panel test show that at the peak stress decreases significantly as the temperature increases (around 30\% and $75 \%$ for 600 and $1000^{\circ} \mathrm{C}$, respectively). It can also be observed that the softening is less evident as the temperature increases, probably because the more accentuated viscopastic behavior at higher temperatures.
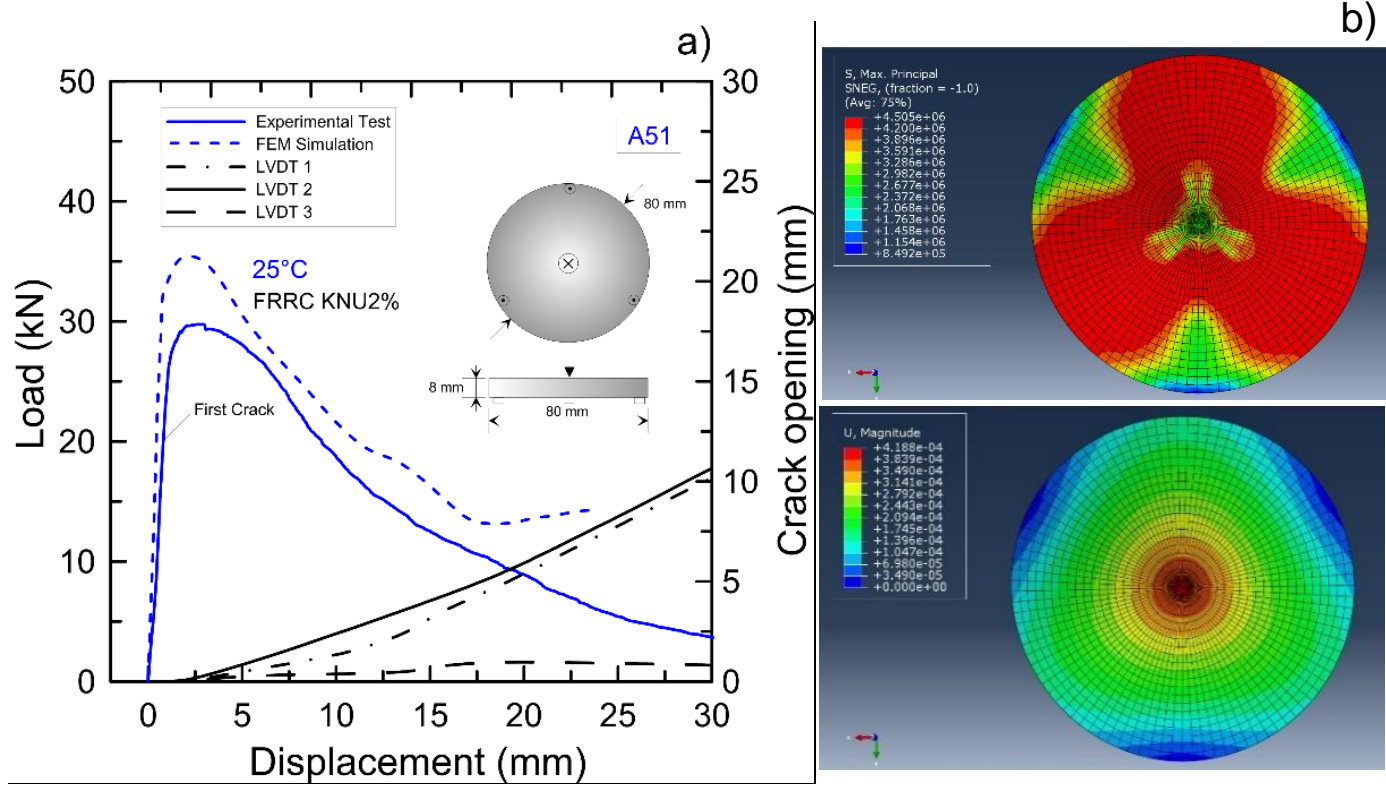

Figure 14 - Round panel tests for the $2 \%$ SFRRC at $25^{\circ} \mathrm{C}$ a) Comparison of finite element analysis and experimental b) Stress and displacement fields immediately after the initiation of the first crack. 


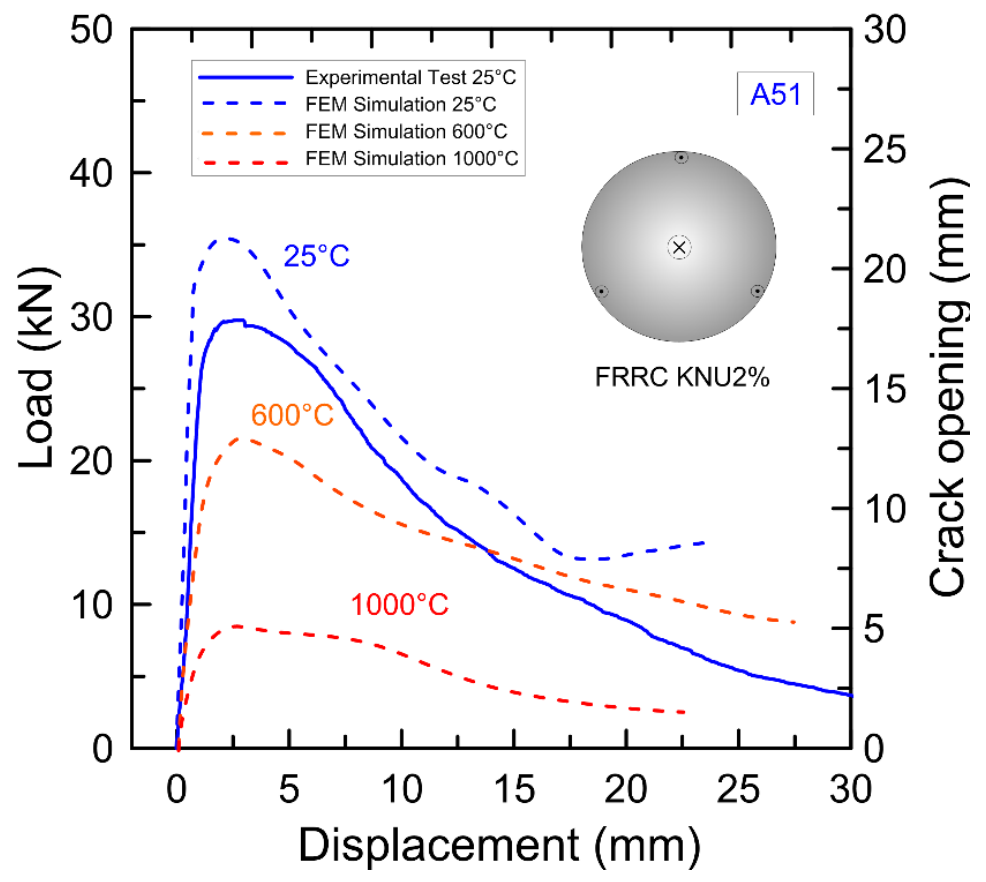

Figure 15 - Simulations results of round panel tests for the $2 \%$ SFRRC exposed at $25,600,1000^{\circ} \mathrm{C}$.

Table 10 - Mechanical properties and parameters for concrete damage plasticity model (CDP).

\begin{tabular}{|c|c|c|c|}
\hline \multirow{2}{*}{ Properties and Parameters (CDP) } & \multicolumn{3}{|c|}{ Composites } \\
\hline & $\mathrm{KNU} 2 \% 25^{\circ} \mathrm{C}$ & KNU2\% $600^{\circ} \mathrm{C}$ & $\mathrm{KNU} 2 \% 1000^{\circ} \mathrm{C}$ \\
\hline Elastic Modulus E (GPa) & 21.00 & 11.70 & 5.26 \\
\hline First crack (kN) & 20.60 & 10.80 & 5.00 \\
\hline Fracture energy $G_{F}(J)$ & 27.00 & 14.70 & 4.95 \\
\hline Dilation angle $(\psi)$ & 36 & 36 & 36 \\
\hline Eccentricity & 0.10 & 0.10 & 0.10 \\
\hline Compressive yield stress ratio $\sigma_{b o} / \sigma_{c o}$ & 1.16 & 1.16 & 1.16 \\
\hline Kc & 0.67 & 0.67 & 0.67 \\
\hline Viscosity & 0.0001 & 0.0001 & 0.0001 \\
\hline
\end{tabular}


Table 11 - Constitutive model data of composites behavior for concrete damage model (CDP).

\section{Composites}

\begin{tabular}{|c|c|c|c|c|c|c|c|c|c|}
\hline \multicolumn{4}{|c|}{ KNU2\% $25^{\circ} \mathrm{C}$} & \multicolumn{3}{|c|}{$\mathrm{KNU} 2 \% 600^{\circ} \mathrm{C}$} & \multicolumn{3}{|c|}{$\mathrm{KNU} 2 \% 1000^{\circ} \mathrm{C}$} \\
\hline \multicolumn{2}{|c|}{$\begin{array}{c}\text { Compressive } \\
\text { Behavior }\end{array}$} & \multicolumn{2}{|c|}{$\begin{array}{c}\text { Tensile } \\
\text { Behavior }\end{array}$} & \multicolumn{2}{|c|}{$\begin{array}{c}\text { Compressive } \\
\text { Behavior }\end{array}$} & \multirow[t]{2}{*}{$\mathrm{G}_{\mathrm{F}}$} & \multicolumn{2}{|c|}{$\begin{array}{c}\text { Compressive } \\
\text { Behavior }\end{array}$} & $\mathbf{G}_{\mathrm{F}}$ \\
\hline Yield & Inelastic & Yield & Crack & Yield & Inelastic & & Yield & Inelastic & \\
\hline Stress & Strain & Stress & Strain & Stress & Strain & & Stress & Strain & \\
\hline 20.60 & 0.00000 & 4.50 & 0.0000 & 10.80 & 0.00000 & 14.7 & 5.00 & 0.00000 & 4.95 \\
\hline 25.51 & 0.00062 & 5.14 & 0.0001 & 14.03 & 0.00149 & & 9.41 & 0.00015 & \\
\hline 30.42 & 0.00055 & 4.08 & 0.0002 & 18.53 & 0.00161 & & 16.35 & 0.00116 & \\
\hline 38.11 & 0.00052 & 3.64 & 0.0010 & 24.94 & 0.00186 & & 19.61 & 0.00395 & \\
\hline 42.12 & 0.00078 & 3.18 & 0.0042 & 29.98 & 0.00237 & & 19.46 & 0.00826 & \\
\hline 53.02 & 0.00191 & 2.70 & 0.0069 & 22.34 & 0.00443 & & 17.66 & 0.01387 & \\
\hline 42.38 & 0.00296 & 2.07 & 0.0091 & 18.51 & 0.00646 & & 15.04 & 0.02288 & \\
\hline 26.83 & 0.00614 & & & 14.27 & 0.01021 & & 13.37 & 0.03067 & \\
\hline 21.35 & 0.0112 & & & 11.52 & 0.01498 & & 11.84 & 0.03860 & \\
\hline 12.75 & 0.0159 & & & 7.26 & 0.02556 & & & & \\
\hline
\end{tabular}

\subsubsection{Three-point bending tests}

The numerical simulation analysis of three-point bending tests was performed for notched composites $\mathrm{KNU} 2 \%$ at $25^{\circ} \mathrm{C}, 600^{\circ}$ and $1000^{\circ} \mathrm{C}$ using the developed concrete damage plasticity model. The objective of these simulation was to investigate the changes in damage and on the stresses fields with the increase in temperature. The finite element model was developed in ABAQUS assuming plane stress conditions. The adopted mesh had 1023 quadrilateral quadratic plane stress finite elements with reduced integration, which is referred to as CPS8R in 
ABAQUS. This mesh was selected after a study of convergence with a tolerance of $5 \%$. The mesh was more refined in the central zone around of the notch. The thickness of the cut was $2 \mathrm{~mm}$, as it was in the experiment. In the areas located far from de notch, a coarser mesh was adopted, as no stress concentrations were expected, to reduce the number of degrees of freedom, and, consequently the computational time. The entire prism was modeled because it was predicted that some of the stresses field could evolve asymmetrically (Figure 16). The supports $140 \mathrm{~mm}$ apart in the test were modeled by restraining all the degrees of freedom at the corresponding nodes in the finite element mesh. To simulate the loading applied to the tested specimen, a displacement is imposed at the center on top of the prism.

The normal stress in the longitudinal direction and strain fields around the notch plane at the end of loading $(\mathrm{u}=0.1 \mathrm{~mm})$ at different temperatures $(25,600$ and $1000^{\circ} \mathrm{C}$ ) are shown in Figure 16 . The strain concentration around the notch observed during the bending test induces a concentration of the stresses that is evident in the stress field distribution. While the simple bending of an unnotched specimen would have a nearly uniaxial state of stress, $\left(\sigma_{x} \neq 0\right.$ and $\left.\sigma_{y}=0\right)$ defined as the horizontal axis $\mathrm{X}$ and the vertical axis $\mathrm{Y}$, in the median plane of the prism, the stress state in a notched specimen is more complex and closer to a biaxial state of stress in the zone near the notch tip. The maximum normal stress obtained was approximately $4.00 \mathrm{MPa}$ and it was reached at the zone around the notch tip, as expected. 


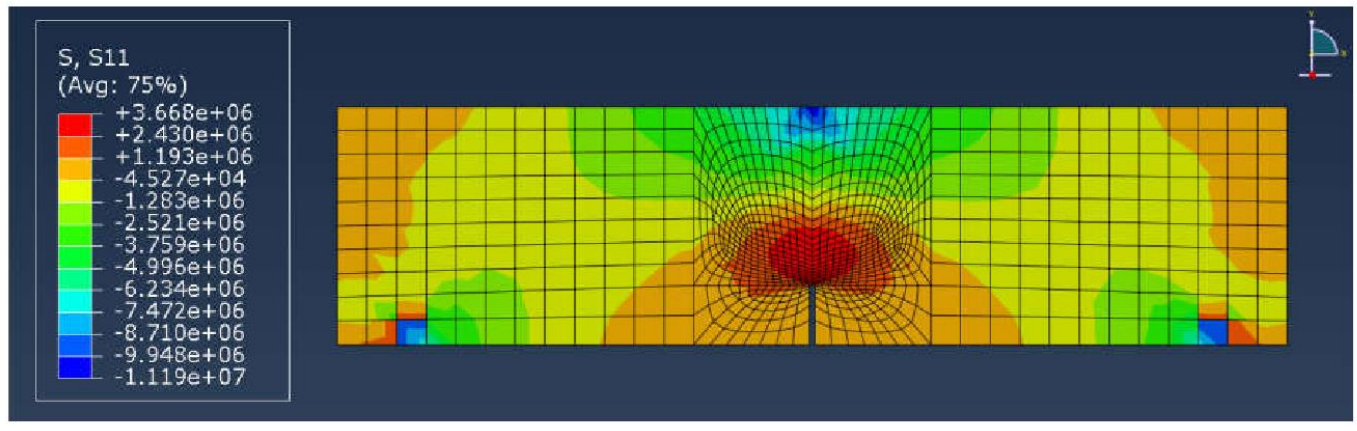

$25^{\circ} \mathrm{C}$

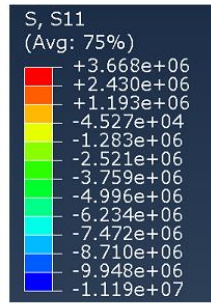

$600^{\circ} \mathrm{C}$
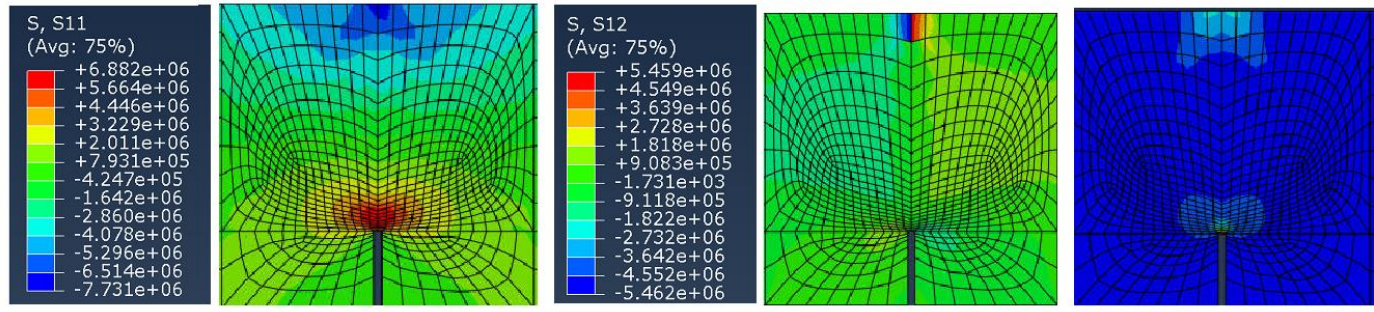

$1000^{\circ} \mathrm{C}$
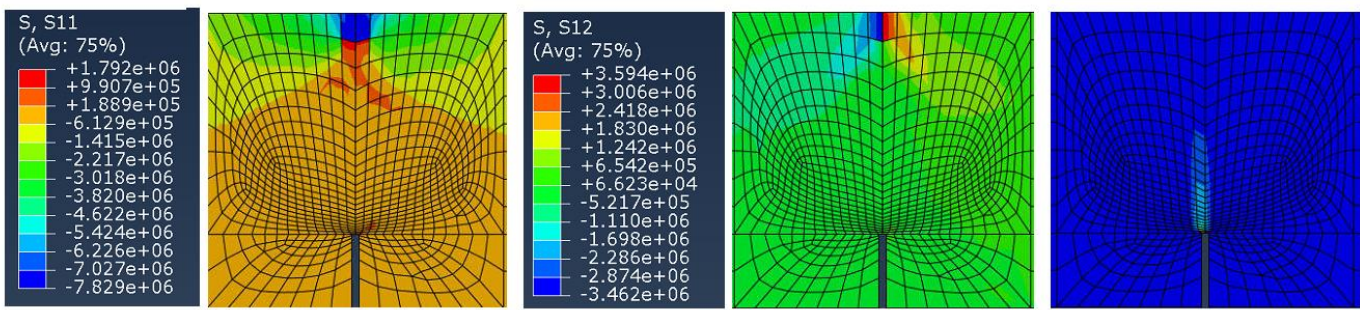

Figure 16 - Normal stresses $\sigma_{\mathrm{x}}$ and shear stress $\sigma_{\mathrm{xy}}$ displacement fields immediately after limit of proportionality three-points bending tests for the $2 \%$ SFRRC.

The evolution of normal stresses $\left(\sigma_{\mathrm{x}}\right)$ along the resistant section (prism section $30 \mathrm{mmx} 40 \mathrm{~mm}$ above the notch) with imposed displacement up to $0.1 \mathrm{~mm}$ is shown in Figure 17. The results at nodes along resistant section were extracted and plotted for the temperatures of 25,600 and $1000^{\circ} \mathrm{C}$. As can be seen, the nodes near the notch tip undergo tensile stresses, while the nodes far from the notch tip and near 
the upper face of the sample are under compressive stresses. The nodes located in the intermediate part are subjected to tensile stress that tends to remain constant, with a slight peak before it becomes compressive. At the beginning of the bending test the maximum stress occurs at the notch tip. The evolution of stresses along the resistance section is similar for all temperatures. The crack propagation from notch tip varied for the different temperatures considered. This means that for the same displacement, for higher temperatures $\left(600\right.$ and $\left.1000^{\circ} \mathrm{C}\right)$ the stress concentration zone near the crack tip moves higher up the section. This cracking propagation behavior is analyzed in depth in the following section using a Digital Image Correlation (DIC) analysis.

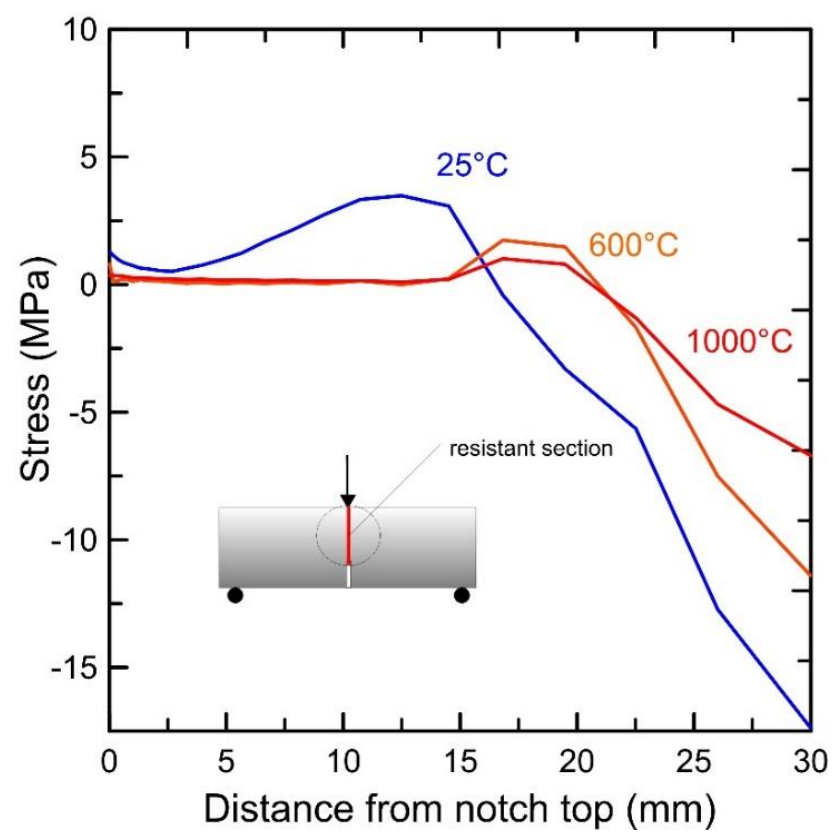

Figure 17 - Normal stress $\sigma_{\mathrm{x}}$ evolution with the imposed displacement at top nodes $(0.1 \mathrm{~mm})$ at notch section at different temperatures $\left(25,600\right.$ and $\left.1000^{\circ} \mathrm{C}\right)$. 


\subsection{Digital Image Correlation (DIC)}

Figure 18 presents the results obtained from DIC measurements performed on FRRC specimens exposed to 25,600 and $1000^{\circ} \mathrm{C}$ for the three-point bending test. The major strain field $\left(\varepsilon_{1}\right)$ of the composite KNU2\% was collected at three different stages in the stress-CMOD curves (Figure 18a): 1) initial phase of first macrocrack, 2) the point where the ultimate stress was reached and 3) at the final point, i.e. failure. Figure $18 \mathrm{~b}$ shows the area of interest near the notch, where the macrocrack is initiated. As can be seen from Figures $18 \mathrm{c}-18 \mathrm{e}$, the strain fields illustrate the capacity of the reinforced composite to redistribute the stress [19]. For the strain state at the specimens a color code is used, where the blue color represents very low strain values and red represents $2.3 \%$ strain value. A macrocrack initiated from the notch is observed for specimens submitted to the residual bending tests at $25^{\circ} \mathrm{C}, 600{ }^{\circ} \mathrm{C}$ and $1000^{\circ} \mathrm{C}$. The propagation of macrocrack is stable for all specimens and multicracking develop, because of bridging fibers effects. From Figures $18 \mathrm{c}-18 \mathrm{e}$ it is possible to compare the failure mechanisms for samples exposed to $25^{\circ} \mathrm{C}, 600^{\circ} \mathrm{C}$ and $1000^{\circ} \mathrm{C}$, respectively, at different stages of the test. In comparison with the unfired composite, the fired composites at $600^{\circ} \mathrm{C}$ presented more initial cracks. This behavior may be due to specific damage mechanisms at the fiber/concrete interfaces caused by internal stress fields induced by the firing at that temperature [19]. For composite fired at $1000^{\circ} \mathrm{C}$ a pattern crack with a lower amount of microcracks was observed. At this temperature $\left(1000^{\circ}\right)$ the transfer of tensile forces to the fibers occurred more rapidly, as a result of matrix damage due to the change of its behavior to viscoplastic. 
a)

b)
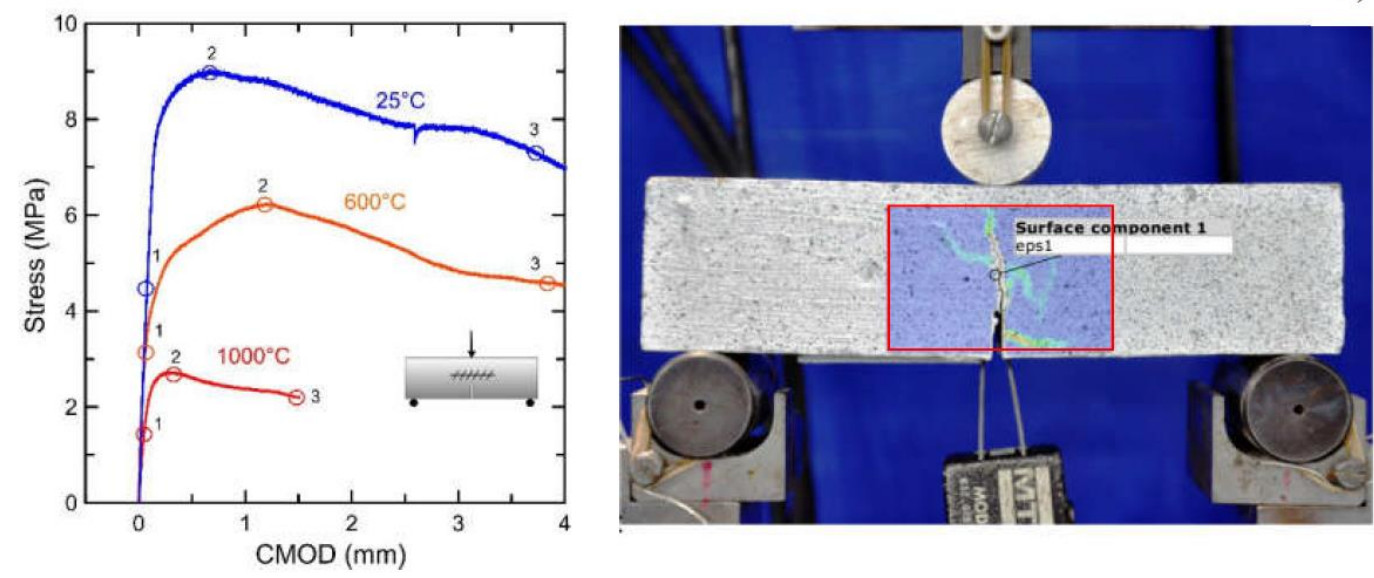

c) $25^{\circ} \mathrm{C}$

1)

2)

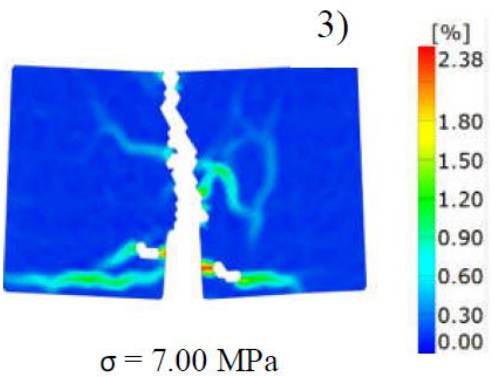

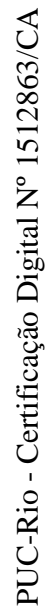

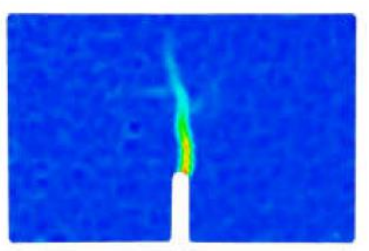

$\sigma=4.20 \mathrm{MPa}$

d) $600^{\circ} \mathrm{C}$

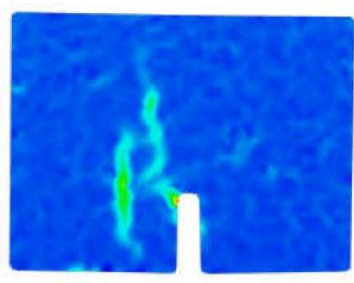

$\sigma=3.10 \mathrm{MPa}$

e) $1000^{\circ} \mathrm{C}$

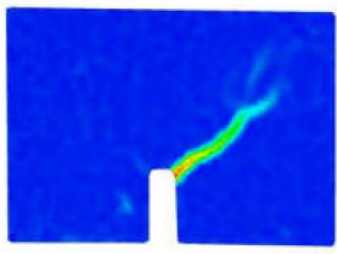

$\sigma=1.60 \mathrm{MPa}$
1)

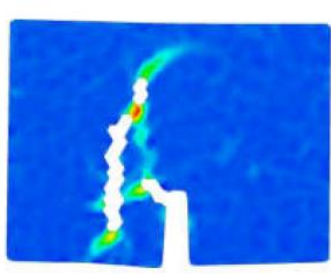

$\sigma=6.30 \mathrm{MPa}$

2)

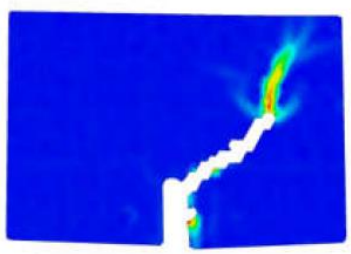

$\sigma=2.80 \mathrm{MPa}$

2)

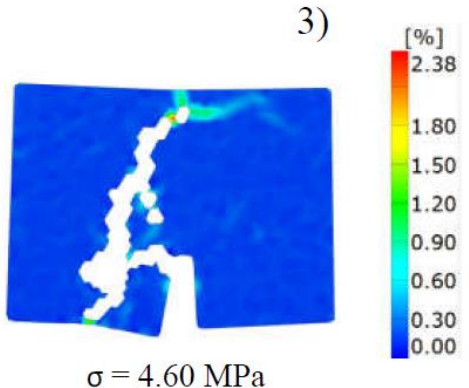

3)

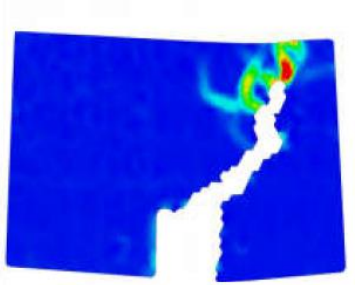

$\sigma=2.20 \mathrm{MPa}$

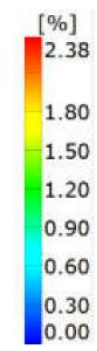

Figure 18 - Strain fields determined by DIC at final step of a three-points bending tests for the $2 \%$ SFRRC at $25^{\circ} \mathrm{C}$. 
The distribution of the major strain along an inspection section (Figure 19) line immediately above the notch tip are extracted from DIC analysis is illustrated in Figure 20.

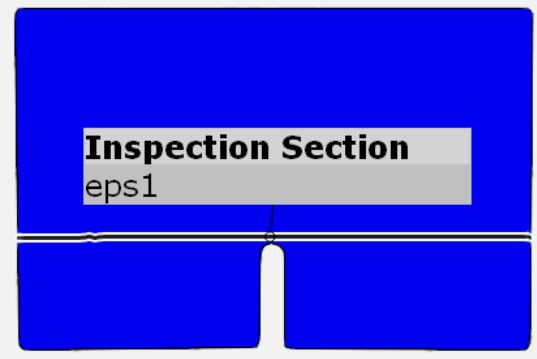

Figure 19 - Inspection section from DIC

The evolution with time and stress level of the strain distribution are presented at three stages: the first indicates the first cracking, the second corresponds to the stress peak and the third corresponds to the final rupture. Similar to that observed in the strain maps, the concentration of tensile stress occurs near the crack and regions distant from the cracks are under constant strain. The deformation values are relatively high at the peak, near the crack. The crack propagation response was analyzed by the width of debonding zone $\left(\mathrm{h}_{\mathrm{D}}\right)$, which was measured from the DIC analysis. The debonding zone is referred to the zone where the fiber and matrix start to de bond and pull out [20]. This measurement is associated to the bond characteristics of the system, i.e, the smaller the width of debonding zone, the higher the bond strength. The width of debonding zone $\left(\mathrm{h}_{\mathrm{D}}\right)$ for the temperatures of 25 , and $1000^{\circ} \mathrm{C}$ were measured as $4.70 \mathrm{~mm}$ and $7.50 \mathrm{~mm}$, respectively. Therefore, the largest width was obtained at high temperatures, which is associated to the loss of the adhesion between the fiber and the matrix. 

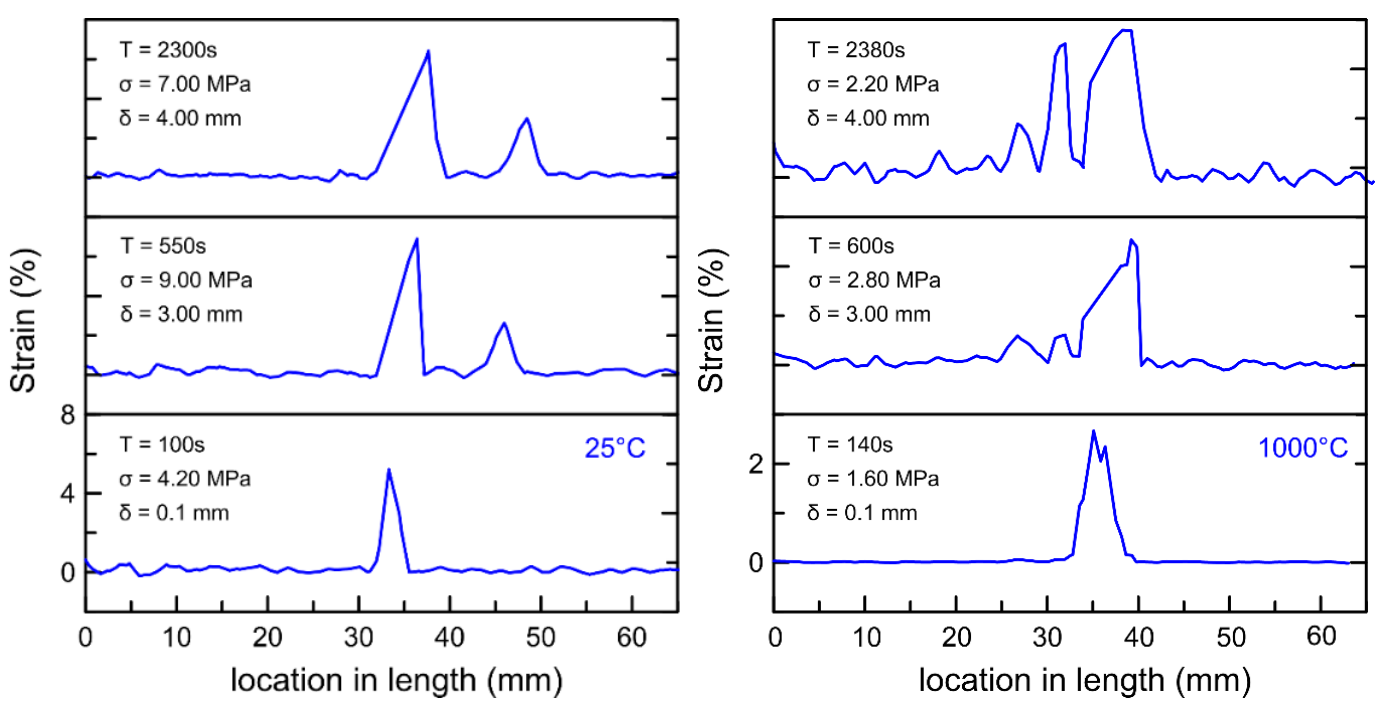

Figure 20 - Major strain vs. location at different steps obtained by DIC for temperatures: a) $25^{\circ} \mathrm{C}$ and b) $1000^{\circ} \mathrm{C}$.

\section{Conclusions}

The main conclusions reached from the experimental tests and FE simulations of stainless steel fiber reinforced refractory composites at different temperatures are the following:

- Each fiber reinforcement shape used to reinforce the studied refractory exhibits a specific thermomechanical behavior at different temperatures.

The three-point bending showed that each composite has a strain-hardening behavior, but with different intensities in the macrocrack formation.

- The stress-CMOD curves of the flexural tests are highly influenced by the fiber volumetric fraction, showed that the reinforcement effect benefits the pre-peak and post-peak behavior of the refractory concretes. The influence on the softening curves indicates the importance for the structural projects.

- The knurled stainless-steel fiber proved to be more resistant in the flexural assemblies at most temperatures in relation to the corrugated and straight 
fibers. This is associated with the stronger bond to the matrix it provides due to the knurled of the fiber surface, which was verified in the pullout tests.

- The constitutive model of the refractory composite used in numerical simulations was validated using the round panel test. This is important for further use in material and structural designs. The concrete damage plasticity model (CDP) proved enables a proper to simulate the non-linear behavior of the reinforced refractory concrete structures.

- The numerical analysis can be used to design structural elements with fiber reinforced at different boundary conditions, saving an enormous laboratory time.

- The developed refractory composites showed thermomechanical behavior suitable for use in applications involving high temperatures up to $1000^{\circ} \mathrm{C}$.

\section{Acknowledgment}

The authors are grateful for the development of this research to PUC-Rio and FAPERJ.

\section{References}

[1] W.G. Bareiro, F. de Andrade Silva, E.D. Sotelino, O. da F.M. Gomes, The influence of alumina content on the chemical and mechanical behavior of refractory concretes fired at different temperatures, Constr. Build. Mater. 187 (2018) 1214-1223. doi:10.1016/j.conbuildmat.2018.08.065.

[2] T. Cutard, N. Donval, F. Nazaret, N. Schmitt, Fibre Reinforced Ref Ractory Concrete As a Tooling Material for Organic Matrix Composite Pro Cessing Routes, (2012) 24-28.

[3] F. Nazaret, T. Cutard, Thermomechanical Behaviour of a Fibre-Reinforced Refractory Concrete: Tests and Fe Analysis, 6th RILEM Symp. FibreReinforced Concr. - BEFIB. (2004) 689-698. 
[4] A. Meddah, L. Belagraa, M. Beddar, Effect of the fibre geometry on the flexural properties of reinforced steel fibre refractory concrete, Procedia Eng. 108 (2015) 185-192. doi:10.1016/j.proeng.2015.06.135.

[5] Standard test method for flexural toughness and first crack strength of fibre reinforced concrete (Using beam with third- point loading)., Am. Soc. Test. Mater. 4 (1998) 1-8.

[6] F. Recommendation, Rilem TC 162-TDF: Test and design methods for steel fibre reinforced concrete - Bending test, Mater. Struct. Constr. 35 (2002) 579-582. doi:10.1617/13884.

[7] BS EN 14651, Test method for metallic fibred concrete - Measuring the flexural tensile strength (limit of proportionality (LOP), residual), Br. Stand. Inst. 3 (2005) 1-17. doi:9780580610523.

[8] FIB, Model Code 2010, 2011. doi:10.1002/9783433604090.ch6.

[9] M.B. B. Mobasher, A. Bonakdar, Fracture Mechanics Applications in Concrete, 2015.

[10] L. Scheinherrová, M. Dolez, M. Keppert, E. Vejmelková, D. Kon, C. Robert, High temperature durability of fiber reinforced high alumina cement composites, 162 (2018) 881-891. doi:10.1016/j.conbuildmat.2018.01.076.

[11] M. Nematzadeh, J. Dashti, B. Ganjavi, Optimizing compressive behavior of concrete containing fine recycled refractory brick aggregate together with calcium aluminate cement and polyvinyl alcohol fibers exposed to acidic environment, Constr. Build. Mater. 164 (2018) 837-849. doi:10.1016/j.conbuildmat.2017.12.230.

[12] S.P. Shah, RILEM Technical Committee 89-FMT. Determination of fracture parameters (KI and CTODc ) of plain concrete using three-point bend tests, Mater. Struct. 23 (1991) 457-460. doi:10.1007/BF02472029.

[13] B. Boulekbache, M. Hamrat, M. Chemrouk, S. Amziane, Flexural behaviour of steel fibre-reinforced concrete under cyclic loading, Constr. Build. Mater. 126 (2016) 253-262. doi:10.1016/j.conbuildmat.2016.09.035.

[14] F. Nazaret, H. Marzagui, T. Cutard, Influence of the mechanical behaviour specificities of damaged refractory castables on the Young's modulus determination, J. Eur. Ceram. Soc. 26 (2006) 1429-1438. doi:10.1016/j.jeurceramsoc.2005.03.231.

[15] F. Minelli, G.A. Plizzari, Fiber reinforced concrete characterization through round panel test - part I: experimental study, Fract. Mech. Concr. Concr. Struct. (2010) 1451-1460.

[16] F. Minelli, G.A. Plizzari, Fiber reinforced concrete characterization through round panel test - Part II: analytical and numerical study, Fract. Mech. Concr. Concr. Struct. (2010) 1451-1460. 
[17] M.R. Mitchell, R.E. Link, F. Minelli, G. Plizzari, A New Round Panel Test for the Characterization of Fiber Reinforced Concrete: A Broad Experimental Study, J. Test. Eval. $39 \quad$ (2011) 103392. doi:10.1520/JTE103392.

[18] Y. Sümer, M. Aktaş, Defining parameters for concrete damage plasticity model, Chall. J. Struct. Mech. 1 (2015) 149-155.

[19] T. Cutard, N. Donval, A. Mazzoni, C. Michel, F. Nazaret, Thermomechanical Characterization of Monolithic Refractory Castables, Adv. Sci. $\quad$ Technol. $\quad 70 \quad$ (2010) 37-46. doi:10.4028/www.scientific.net/AST.70.37.

[20] D.A.S. Rambo, Y. Yao, F. de Andrade Silva, R.D. Toledo Filho, B. Mobasher, Experimental investigation and modelling of the temperature effects on the tensile behavior of textile reinforced refractory concretes, Cem. Concr. Compos. 75 (2017) 51-61. doi:10.1016/j.cemconcomp.2016.11.003. 